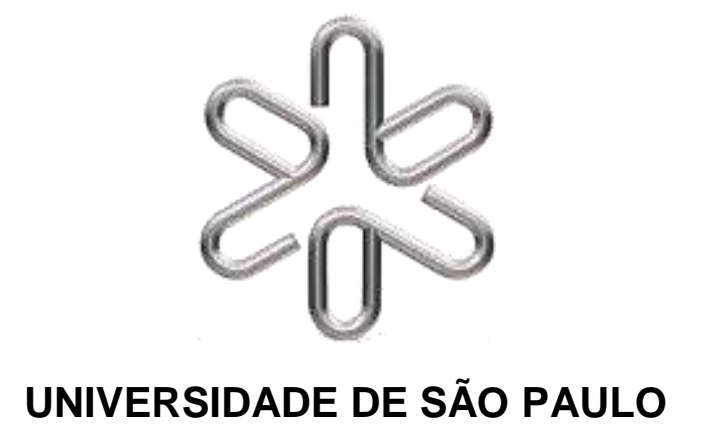

Programa de Pós-Graduação Interunidades em Ensino de Ciências

\author{
BEATRIZ CRITTELLI AMADO
}

APRENDENDO A OUVIR AQUELES QUE NÃO OUVEM: $O$ DESAFIO DO PROFESSOR DE CIÊNCIAS NO TRABALHO COM A LINGUAGEM CIENTÍFICA COM ALUNOS SURDOS

SÃO PAULO 


\section{APRENDENDO A OUVIR AQUELES QUE NÃO OUVEM: O DESAFIO DO PROFESSOR DE CIÊNCIAS NO TRABALHO COM A LINGUAGEM CIENTÍFICA COM ALUNOS SURDOS}

Dissertação apresentada ao Programa de Pós Graduação Interunidades em Ensino de Ciências da Universidade de São Paulo como requisito para a obtenção do título de Mestre em Ensino de Ciências.

Área de concentração: Ensino de Biologia

Orientadora: Prof $^{\underline{a}}$ Dr $^{\mathrm{a}}$ Celi Rodrigues Chaves Dominguez

Banca Examinadora:

Prof $^{-}$Dr $^{\mathrm{a}}$ Celi Rodrigues Chaves Dominguez - EACH/USP Prof ${ }^{-}$Dr ${ }^{a}$ Alessandra Bizerra - IB USP

Prof ${ }^{a}$ Drª Cássia Geciauskas Sofiato - FE USP

\section{SÃO PAULO}


Autorizo a reprodução e divulgação total ou parcial deste trabalho e de suas imagens, por qualquer meio convencional ou eletrônico, para fins de estudo e pesquisa, desde que citada a fonte adequadamente.

FICHA CATALOGRÁFICA

Preparada pelo Serviço de Biblioteca e Informação do Instituto de Física da Universidade de São Paulo

Crittelli Amado, Beatriz

Aprendendo a ouvir aqueles que não ouvem: o desafio do professor de ciências no trabalho com a linguagem científica com alunos Surdos.

São Paulo, 2017.

Dissertação (Mestrado) - Universidade de São Paulo.

Faculdade de Educação, Instituto de Física, Instituto de Química e Instituto de Biociências.

Orientador: Profa. Dra. Celi Rodrigues Chaves Dominguez

Área de Concentração: Ensino de Ciências - Biologia

Unitermos: 1. Biologia - Estudo e ensino; 2. Ensino de ciências; 3 . Ensino de surdos; 4 . Educação bilíngue; 5 . Libras; 6 . Interação em sala de aula.

USP/IF/SBI-044/2017 
Dedico este trabalho:

a Deus, em primeiro lugar, que me presenteou com essa oportunidade; ao meu marido e minha família, pelo apoio que sempre me deram e me dão, e aos Surdos, como uma forma de agradecimento por tudo o que me ensinaram e como reconhecimento por toda sua luta. 


\title{
AGRADECIMENTOS
}

\begin{abstract}
"Confie no Senhor de todo seu coração, e nunca pense que sua própria capacidade é suficiente para vencer os seus problemas. Em tudo quanto for fazer, coloque Deus em primeiro lugar. Ele guiará seus passos e você andará pelo caminho do sucesso. (Provérbios 3:5-6)"
\end{abstract}

Para que eu conseguisse concluir esse trabalho, muitas pessoas participaram desse percurso, algumas de forma direta me auxiliando com os conteúdos, discussões no assunto e me instruindo nessa área e outras de forma indireta, me dando forças, apoiando e sendo companheiras a todo momento, ou em partes significativas. Mas antes de citar qualquer nome, afirmo com toda certeza que cada pessoa que apareceu na minha vida, Deus colocou lá, à Ele destino a principal fonte do meu agradecimento por ter me guiado, me sustentado e me capacitado para cada palavra escrita aqui. Reconheço assim como está escrito na citação acima que de nada vale minha própria capacidade se Deus não estiver ao meu lado me direcionando a todo momento.

Tentarei prosseguir esses agradecimentos em ordem cronológica iniciando por quem, minha vida toda sempre esteve lá, minha família. Cito nominalmente quem sempre dividiu o lar comigo, minha mãe Yara Cavalheiro Crittelli e meu pai Gerson Crittelli por sempre me instruírem com muita sabedoria e muito amor, me apoiando em todas minhas decisões pessoais e principalmente profissionais desde criancinha, tenho certeza que meu desejo de sempre estar aprendendo mais nasceu desse apoio que me deram e que me dão. Continuando na mesma casa, minha avó Maria Helena Cavalheiro que posso dizer que fez grande parte da minha educação recheada com muito amor e carinho, mesmo não seguindo seus estudos escolares, sempre me incentivou a estudar. E por fim, a minha irmã Carolina Cavalheiro Crittelli que sempre foi e sempre será minha melhor amiga, compartilhamos as mesmas vivências por muitos anos e hoje tenho o prazer de compartilhar com ela nossos estudos e vidas profissionais que seguiram na área da educação, e também incluo nesse agradecimento meu cunhado Bruno Sousa que mesmo sendo de uma área diferente, posso afirmar, e nessa incluo minha irmã 
também, que nos apoia em nossas escolhas e nos incentiva. Cito aqui também minha família estendida que envolve todos meus avós, inclusive os falecidos que mesmo partindo, ainda tem um espaço no meu coração; meus tios; e primos queridos, a toda minha família destino meus sinceros agradecimentos e amor.

Agora cito quem atualmente divide o lar comigo, meu marido André Amado Aguiar, a quem posso dizer que desde quando nos conhecemos, me tem dado amor, carinho, apoio, afeto e companheirismo a todo o momento, principalmente quando iniciei essa pesquisa. Esses sentimentos nunca diminuíram de acordo que crescia meus trabalhos e afazeres relacionados com essa pesquisa, pelo contrário, só cresciam e continuam crescendo. Com ele divido todos esses meus sentimentos e agradeço por permitir dividir e compartilhar meus pensamentos, afirmo com toda certeza que mesmo não sendo dessa área, me ajudou muito a fundamentar essa pesquisa. E junto dele, a minha segunda família que ganhei de presente, incluo aqui seus pais Márcia Amado da Silva Aguiar, Gilberto Aguiar, meus cunhados Aline Amado Aguiar Simas, Raphael Simas, aos avós, tias, tios, primas e primos, agradeço a cada um por todo o carinho.

Ao entrar na Faculdade, fiz amizades que me marcarão a vida toda, Raquel Franz e Eliane de Santana. Essas são aquelas amigas que encontro pouco presencialmente, mas que as memórias continuam tão vivas que a cada encontro lembramos tudo com prazer. Elas fizeram parte da minha trajetória até aqui, por isso deixo registrado meu carinho e agradecimento.

Durante a Faculdade, precisei escolher a escola que iria estagiar. Por um contratempo precisei trocar a minha primeira escola, mas a minha segunda escola que originou essa dissertação aqui foi direcionada por uma pessoa a quem tenho muito carinho e que agradeço de coração, a Educadora da USPLeste Josely Cubero. Talvez não saiba o quanto sua vida foi importante para mim, mas se não fosse esse desafio lançado eu nunca teria a oportunidade de chegar onde cheguei.

Deixo um agradecimento especial à Escola Bilíngue de Surdos que realizei meu estágio durante a Graduação e minha pesquisa de campo durante o Mestrado, principalmente à Coordenadora Heloísa pelo carinho, humor e acolhimento que sempre me recebeu e ao Professor Danilo Prado Ramos, por 
ter me dado abertura em suas aulas para realizar esse trabalho e ter a humildade em sempre se dispor a discutir e me ajudar com essa a minha pesquisa.

Agora, quero deixar agradecimentos especiais às Professoras que me marcaram, desde a minha trajetória da Faculdade até o momento que estou.

A começar com minha orientadora que fez jus a esse nome, Prof. ${ }^{a}$ Dr. ${ }^{\underline{a}}$ Celi Rodrigues Chaves Dominguez. Me acompanhou em alguns períodos durante a faculdade e durante todo o mestrado, e foi muito mais do que uma orientadora para mim. Esteve comigo em cada passo que dei para a construção dessa dissertação, trabalhos para eventos, e até mesmo me orientando para outros momentos que passei nesse período. Isso sem contar o quanto que posso chamar esse trabalho não só de "meu" e sim de "nosso" pelo quanto que se doou por ele, mesmo em momentos mais difíceis. Sou eternamente grata pelo amor, carinho e cuidado que teve comigo, é um exemplo de Professora que pretendo seguir em minha vida.

E continuando a citar professoras que marcaram minha trajetória, cito dois nomes que me acompanham desde a graduação: Prof. ${ }^{\text {a }}$ Dr. ${ }^{\text {a }}$ Maria Elena Infante Malachias que me incentivou e me mostrou o amor que existe nessa profissão e a Prof. a Dr. ํ Verónica Guridi por me acolher e me instruir com muito carinho na monitoria, me formando como futura professora. Nessa área de Ensino de Ciências, tive a oportunidade de conhecer também a Prof. $\underline{\text { a }}$ Dr. $\underline{\text { a }}$ Alessandra Fernandes Bizerra que me serve de inspiração pela sua atenção para com os alunos e por sempre estar de coração aberto para novos conhecimentos, refletindo em suas aulas na Faculdade.

$\mathrm{Na}$ Educação Especial, conheci algumas professoras que deixaram marcas em minha formação. Cito a Prof. ${ }^{\text {a }}$ Dr. ${ }^{\text {a }}$ Karina Maldonado por me receber de braços abertos como monitora da área de Educação Especial e Libras, me permitindo uma participação ativa nas aulas e também a oportunidade de trabalhar no Laboratório de Educação Especial da Faculdade de Educação. A Prof. ${ }^{a}$ Dr. ${ }^{\text {a }}$ Cássia Gesiauskas Sofiato por também me receber carinhosamente como monitora na matéria de Libras, além de contribuir com minha formação para a área trazendo discussões muito bem fundamentadas em suas aulas e conversas sobre a pesquisa. Outra Professora que marcou minha formação e se abriu para a minha futura pesquisa é a Prof. ${ }^{a}$ Dr. ${ }^{a}$ Shirley 
Maia, que me inspira em seu trabalho e pesquisa além de sempre abrir as portas para mim para conversas acadêmicas, pessoais e suportes em tudo que preciso.

Registro aqui também em memória, um agradecimento ao Jucivagno Cambuhy por me ajudar e acompanhar minha pesquisa desde o início, sempre se dispondo a ajudar e com toda a certeza me ajudou a formar o que tenho hoje. Infelizmente não participará da conclusão deste trabalho, mas certamente deixou marcas em vários pesquisadores da área assim como deixou em mim.

As monitorias que realizei durante o período do Mestrado me ensinaram muito além do que é um trabalho docente no Ensino Superior, me ensinou a conviver com estudantes das mais diversas realidades e me abrir a aprender com eles. Em especial, cito duas pessoas que sempre lembrarei com carinho: Marília Mabi e Thaís Gonçalves que para mim, passou de relação de monitora para amizade. Além desses nomes, destaco o nome da Mariana Moura que além de parceira nas atividades de monitoria para os alunos da Faculdade, é parceira também no aprendizado da Libras e também uma amiga na qual posso contar para conversar sobre qualquer assunto e pedir qualquer tipo de ajuda.

Tive também a oportunidade de ministrar alguns cursos da área de "enisno de Ciências e Surdez" com minha querida orientadora, com Josely, parceira em todas as atividades, Juliana Renovato Vizza e Vinícius Rodrigues que realizaram um excelente trabalho de monitoria, fora um forte laço de carinho que criamos entre esse grupo. Além desse grupo, cada turma que ministramos o curso nos deixou marcas e posso afirmar que contribuíram e muito para a fundamentação dessa dissertação.

Agradeço também as amigas que fiz durante esse período do mestrado que me serviram de apoio, tanto pessoal, quanto para compartilhar conversas e me ajudar nessa vida acadêmica. Cito nominalmente a Isabel Rodrigues, Caroline Belaunde por nossos poucos, porém marcantes encontros, e minhas companheiras de eventos Aline Toffoli, Aline Molenzani, Fábia Oliveira e Angélica Niero. Além da Kate Oliveira Kumada por todo apoio e parceria com as atividades acadêmicas e Amanda Hora, parceira não só de monitoria, mas também em conversas e desabafos. 
Cito aqui também meus queridos vizinhos que me acompanharam nessa trajetória, Gustavo Sajonc e Raquel Corrêa, por todo amor, parceria, carinho e jantinhas nesse tempo. Registro também o nome da Tamires Mendes da Purificação, amizade preciosa para mim, agradeço por todo o carinho, conversas e discussões que temos, me abre a cabeça para fora do mundinho em que me encontro.

Continuando a citar pessoas que me sustentam em amizade, menciono aqui com muito carinho o grupo de amigos que além de estudarem Libras comigo, me fortalecem e me motivam com muito amor e humor a continuar estudando: Aline Merida, Franciele Lopes, Rafael Firmino, Roberta Veiga e Vinícius de Souza Silva.

Pude contar também com uma excelente equipe de Professores Surdos da Derdic em minha formação: Fábio de Sá, Daniel de Paula, Cristiano Koyama e Ricardo Nakasato que me ensinaram muito além da Libras, também o que é a vida de um Surdo. Em especial, deixo aqui em agradecimento o nome de um amigo Surdo, Rafael Cavichiolli, que desde o começo, estabelecemos uma relação de "protocooperação" como brincamos, sempre um ajudando o outro, e é um exemplo de dedicação e determinação, espero daqui alguns anos estar lendo sua dissertação. Além disso, cito também o nome da Bruna Patrícia da Silva, na qual começamos com uma relação de trabalho e que cada vez mais fundamentamos uma relação de confiança e parceria, me ensinando dia-a-dia as batalhas de uma pessoa que enxerga o mundo não com seus olhos, e que luta para que as pessoas com deficiência visual possam ser de fato visibilizadas da maneira que merecem.

Nesse período de pesquisa, tive a oportunidade de conhecer intérpretes de Libras incríveis que me inspiraram e continuam me inspirando a continuar aprendendo essa língua. Em particular, cito meu amigo Thyago Santos que me ajudou a fundamentar essa pesquisa com ideias, críticas e sugestões e também me serve de exemplo em conhecimento e interpretação da Libras.

Além de todos os nomes mencionados, cito aqui cada pessoa participante dos "Batistas no Pacaembú" e minhas amizades do grupo de jovens por sempre me apoiarem nesse trabalho e me sustentarem em oração. 
A todas e todos citados aqui, meu "MUITO OBRIGADA" de todo o coração. Espero de verdade conseguir retribuir ou pelo menos demonstrar na mesma medida tudo o que cada uma/ cada um aqui fiz por mim. 


\section{RESUMO}

CRITTELLI, B. A. Aprendendo a ouvir aqueles que não ouvem: o desafio do professor de ciências no trabalho com a linguagem científica com alunos Surdos. 2017. 185 p. Dissertação (Mestrado) apresentada ao Instituto de Física, ao Instituto de Química, ao Instituto de Biociências e à Faculdade de Educação da Universidade de São Paulo, 2017.

A educação de alunos Surdos, no Brasil, é respaldada por documentos legais, sendo de escolha do aluno estudar em um contexto inclusivo com o apoio de intérpretes de língua brasileira de sinais (Libras) ou em espaços de educação bilíngue, com a Libras sendo língua de instrução. Ao ter como foco as escolas bilíngues, muitos pontos devem ser levados em consideração no processo de aprendizagem do aluno através da Libras, como, por exemplo: um bom domínio da língua por parte do professor, o uso de diferentes recursos como ferramentas nas aulas, a exploração de aspectos visuais, entre outros. Nas aulas de ciências, somado aos pontos mencionados, o professor deve se preocupar com a significação dos conceitos científicos a partir da Libras, sendo que, em alguns casos, a língua de sinais ainda não contempla esse vocabulário científico. A partir desse quadro, a presente pesquisa foi constituída com o foco de analisar as interações entre professor e os alunos Surdos nas aulas de ciências de uma escola de educação bilíngue, com base nas ferramentas de ensino que o professor utilizou em sua prática, no vocabulário científico utilizado e na avaliação final dos alunos. Essa análise foi pautada por um estudo etnográfico com base nos diários de campo, vídeos das avaliações dos alunos e, também, em uma entrevista realizada com o professor de ciências. Com isso, foram identificados diversos aspectos que podem contribuir tanto para o ensino de ciências para Surdos como para ouvintes quanto à formação do conceito científico em sala de aula. Palavras e sinais da área de ciências carregam consigo um significado conceitual que, em Libras, muitas vezes é construído em aula, pois o vocabulário científico ainda é básico em tal língua. Essa construção pode enriquecer uma aula a depender da metodologia de ensino e de como o professor trabalha em sala de aula e em Libras, podendo se trabalhar com o combinado de sinais ou também com o uso de classificadores, quando identificado que não há o sinal específico. Nas aulas acompanhadas, foi observado que houve combinados de sinais, mas, nas avaliações, muitos alunos não utilizaram esses sinais e nem classificadores para explicar os termos científicos trabalhados, apesar de, durante as aulas, a interação e construção de sinais ter ocorrido de forma intensa. Esperamos que essa pesquisa contribua para que o ensino de ciências seja pensado com base em outras perspectivas e que seja também uma porta para que, a partir desta, outras pesquisas nessa área se desenvolvam.

Palavras chaves: Ensino de Ciências; ensino de Surdos; educação bilíngue; Libras; interação em sala de aula. 


\begin{abstract}
CRITTELLI, B. A. Learning to listen to those who do not listen: the challenge of the science teacher in working with the scientific language with Deaf students. 2017. 185 p. Dissertation (Master's) presented to the Instituto de Física, the Instituto de Química, the Instituto de Biociências and the Faculdade de Educação from Universidade de São Paulo, 2017.
\end{abstract}

The education of Deaf students in Brazil is supported by legal documents, and the student's choice is to study in an inclusive context with the support of interpreters from Libras or in bilingual education spaces, with Libras being a language of instruction. When focusing on bilingual schools, many points should be taken into account in the student's learning process through Libras, such as: a good command of the language by the teacher, use of different resources such as tools in class, the exploration of visual aspects, among others. In science classes, in addition to the points mentioned, the teacher should be concerned with the meaning of the scientific concepts from Libras, and in some cases, sign language still does not contemplate this scientific vocabulary. From this framework, the present research was constituted with the focus of analyzing the interactions between teacher and Deaf students in the science classes of a bilingual education school, based on the teaching tools that the teacher used in his practice, in the vocabulary used and the students' final evaluation. This analysis was based on an ethnographic study based on the diaries, videos of the students' evaluations and also on an interview with the Science Teacher. With this, several aspects were identified that can contribute as much to the teaching of sciences for Deaf as to listeners as to the formation of the scientific concept in the classroom. Words and signs from the area of science carry with them a conceptual meaning which, in pounds, is often constructed in class, because the scientific vocabulary is still basic. This construction can enrich a class depending on the teaching methodology and how the teacher works in the classroom and in Libras, being able to work with the combination of signals or also with the use of classifiers, when identified that there is no specific signal. In the classes followed, it was observed that there were combinations of signals, but in the evaluations, many students did not use these signals and classifiers to explain the scientific terms worked, although during the classes interaction and sign construction occurred in a way Intense We hope that this research contributes to science education being thought from other perspectives and that it is also a door to other research in this area to develop.

Keywords: Science Teaching; Teaching of the Deaf; Bilingual education; Pounds; Interaction in the classroom. 


\section{LISTA DE FIGURAS}

Figura 01: Representação em Libras do meu sinal. Mão aberta com os dedos unidos na região da testa, orientação da palma da mão para baixo, movimento semicircular acompanhando a franja.

Figura 02: Configuração de mãos de acordo com o Instituto Nacional de Educação de Surdos - INES.

Figura 03: Configurações de mãos separadas de acordo com os dedos que as compõem.

Figura 04: Representação do sinal APRENDER (Mão dominante na testa com a configuração em letra "C" fechando para a configuração de mãos em letra "S") e LARANJA (Mão dominante na testa com a configuração em letra "c" fechando para a configuração de mãos em letra "s"), ambos com a mesma configuração de mãos, porém executados em diferentes partes do corpo.

Figura 05: Representação do sinal TRABALHAR (configuração de mãos em letra "L, orientação da palma da mão para dentro, no espaço neutro, movimentar mãos intercalando para cima e para baixo) com o ponto de articulação no espaço neutro frente ao corpo e sinal ESQUECER (mão aberta na testa com orientação da palma para dentro, fazer movimento linear lateral fechando a mão, com expressão facial correspondente) com o ponto de articulação frente a testa.

Figura 06: Representação do sinal BRINCAR (configuração de mãos em letra "Y", orientação da palma da mão para dentro, no espaço neutro fazer movimentos circulares intercalando as mãos) com movimento e sinal EM-PÉ (palma da mão aberta e mão dominante com configuração da mão em letra "V", orientação da palma da mão dominante para dentro, realizado no espaço neutro, sem movimento) que não possui movimento.

Figura 07: Representação do sinal DOCE com a orientação da palma da mão para dentro (mão aberta com dedos unidos, na frente da boca, fazer movimento circular).

Figura 08: Representação do sinal CONFUSÃO (mãos abertas entrelaçadas, orientação da palma da mão para dentro, no espaço neutro movimentar as mãos unidas para cima e para baixo com expressão facial correspondente). 
Figura 09: Representação do sinal PROFESSOR de acordo com os cinco parâmetros.

Figura 10: representação de sinais icônicos e arbitrários.

Figura 11: termos correspondentes nas línguas de sinais e línguas orais.

Figura 12: diferença entre os sinais de CORAÇÃO, o primeiro representando o sinal comum e o segundo o sinal-termo correspondente ao coração como um órgão.

Figura 13: Disposição da pesquisadora na sala de aula durante toda a coleta de dados

Figura 14: Sinais em Libras correspondentes aos termos científicos utilizado pelo Professor de ciências.

Figura 15: Categorias estabelecidas pelo Professor para avaliação colaborativa

Figuras 16, 17, 18: Bancos de palavras levantados pelos alunos em sala e registrados pela pesquisadora em três dias de aula diferentes.

Figura 19: Frases escritas por um aluno a partir da tabela construída pelo Professor, representando a camuflagem.

Figura 20: Representações do jardim da escola indicadas pelo Professor. Nessa atividade os alunos indicavam qual formato eles julgavam ser o real, os números acima dos desenhos revelam a quantidade de alunos que indicaram cada representação.

Figura 21: Representação do pátio desenhada em lousa pelo Professor como base para a atividade prática da aula.

Figura 22: Nomes dos animais desenhados pelos alunos e suas numerações correspondentes.

Figura 23: Categorias a ser indicadas na atividade do pátio seguindo as adaptações defensivas de interação ecológica estudadas.

Figura 24: Desenho da vegetação do jardim da escola, utilizada para a atividade da aula com as associações dos animais e suas relações ecológicas.

Figura 25: Representação da teia alimentar com o posicionamento das setas estipuladas pelos estudantes, evidenciando o direcionamento de qual animal era predador e qual era presa. 
Figura 26: Representação da cadeia alimentar com novas setas estipuladas pelo Professor e destacadas em outra cor, representando novas interações dentro da teia alimentar.

Figura 27: esquema de construção de frases para a representação dos novos processos da teia alimentar.

Figura 28: Tópicos da avaliação dos alunos, combinados na sala entre todos.

Figuras 29 e 30: Alunos na atividade do jardim do Colégio posicionando os animais nos locais que acreditavam ser seus habitats. Na figura 29 o aluno coloca o pássaro em um local mais alto, com a coloração parecida e na figura 30 o aluno posiciona a cobra em meio às folhagens.

Figura 31: Representação de qual deve ser o direcionamento das setas das cadeias alimentares quando se fala em Libras ou em português.

Figura 32: Sinal de PRESA (sinal composto, com a mão dominante, palma aberta e dedos unidos, fazer sinal indicando a outra mão. O outro sinal segue com a configuração da mão dominante em letra " $B$ " fazendo um movimento reto no pescoço) e PREDADOR (sinal composto, com a mão dominante, palma aberta e dedos unidos, fazer sinal indicando a outra mão. $O$ outro sinal segue com a mão semi-dobrada e depois fechando frente a boca) combinado entre o Professor de ciências e os estudantes do sétimo ano " $\mathrm{C}$ ".

Figura 33: Representação do desenho de setas na teia alimentar elaborada pelo aluno Daniel.

Figura 34: Representação comparativa entre os sinais PARECER (dedo polegar, indicador e médio esticados, orientação da palma da mão para dentro, posicionar o indicador e o dedo médio com o nariz no meio e em movimento retilíneo levar a mão frente ao rosto mantendo a mesma configuração de mãos) utilizados pelos alunos em sala de aula com o sinal de MIMETISMO.

Figura 35: Sinal de TEIA ALIMENTAR (configuração de mãos em letra "C", orientação da palma da mão para baixo, com a mão dominante, fazendo movimento semicircular até o antebraço. Repetir o movimento com a outra mão) realizado pelo Professor durante suas aulas. 


\section{LISTA DE TABELAS}

Tabela 01: Tabela com descrição de movimentos possíveis na Libras.

Tabela 02: Descrição de configurações de mãos e seu uso mais frequente na Libras.

Tabela 03: organização dos dados referentes ao levantamento bibliográfico.

Tabela 04: Relação das teses e dissertações em relação ao uso do autor Vigotski como referencial teórico.

Tabela 05: Representação da lousa na atividade do Professor de ciências com os estudantes do sétimo ano $\mathrm{C}$.

Tabela 06: Tabela utilizada para organização das cadeias representadas na teia alimentar estipulada pelos estudantes.

Tabela 07: Representação da tabela utilizada em aula pelo Professor de ciências com o Sétimo ano. A sequência numérica segue a ordem de frases referentes à camuflagem decorrentes de outras atividades.

Tabela 08: Representação da tabela utilizada em aula pelo Professor de ciências com o sétimo ano.

Tabela 09: Tabela utilizada para organização das cadeias representadas na teia alimentar estipulada pelos estudantes. 


\section{LISTA DE GRÁFICOS}

Gráfico 01: Quantidades de trabalhos da área de ensino de ciências para surdos em relação às diferentes áreas da ciência. 


\section{LISTA DE SIGLAS E ABREVIAÇÕES}

APAE: Associação de Pais e Amigos dos Excepcionais

ASL: língua de sinais americana - American sign language

BDTD: Biblioteca digital brasileira de teses e dissertações

BTDC: Banco de Teses e Dissertações da Capes

CM: Configuração de mãos

EMEBS: Escola Municipal de Educação Bilíngue de Surdos

ENM: Expressões não manuais

INES: Instituto Nacional de Educação de Surdos

LBI: Lei Brasileira de Inclusão da Pessoa com Deficiência

LS: língua de sinais

L1: primeira língua, língua materna

L2: segunda língua

Libras: Língua Brasileira de sinais

LDBEN: Lei de Diretrizes e Bases da Educação Nacional

Mov: Movimento

OPM: Orientação das palmas das mãos

PA: Ponto de articulação

PCN: Parâmetros Curriculares Nacionais

PNEEI: Política Nacional de Educação Especial na perspectiva da Educação Inclusiva

TILS: Tradutores e Intérpretes de Libras

Unesco: Organização das Nações Unidas para Educação, Ciência e Cultura. 


\section{SUMÁRIO}

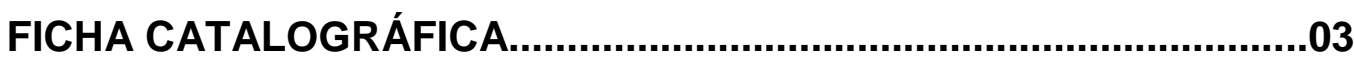

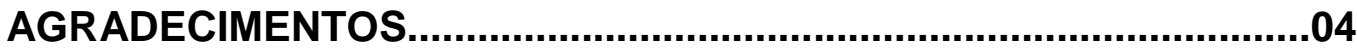

RESUMO

ABSTRACT

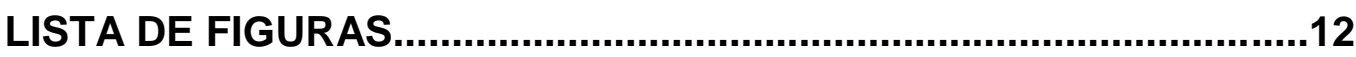

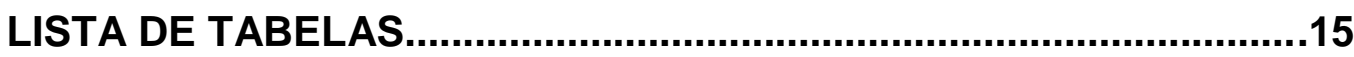

LISTA DE GRÁFICOS......................................................................

LISTA DE SIGLAS E ABREVIAÇÕES................................................17

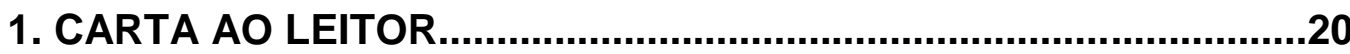

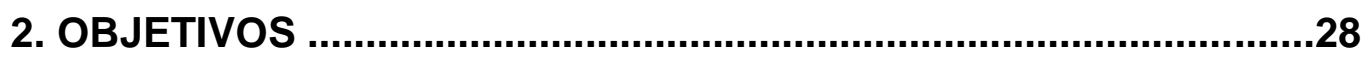

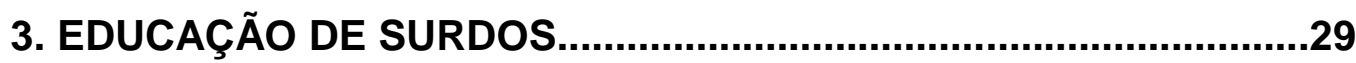

3.1 Da antiguidade até os dias atuais...............................................29

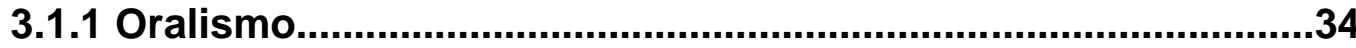

3.1.2 Do Oralismo para a Comunicação Total.....................................36

3.1.3 Bilinguismo como outra forma de enxergar sujeito e língua...38

3.1.4 $O$ professor e 0 aluno Surdo no contexto bilíngue....................40

3.1.5 Contexto histórico no Brasil...................................................42

3.2 Políticas públicas relacionadas à educação de Surdos...............44

3.2.1 Panorama Nacional e Internacional..........................................45

3.2.2 De "Escolas Especiais" a "Escolas Bilíngues para Surdos"...50

3.3 Cultura Surda e identidade linguística.........................................53

3.4 Língua brasileira de sinais - Libras...........................................60

3.4.1 Parâmetros da Libras.............................................................61

3.4.2 Aspectos básicos da Libras...................................................72

3.4.2.1 Iconicidade e Arbitrariedade....................................................

3.4.2.2 Fonologia

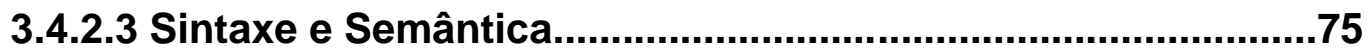




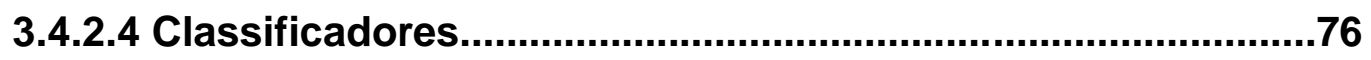

3.4.3 Aquisição da língua ..................................................................77

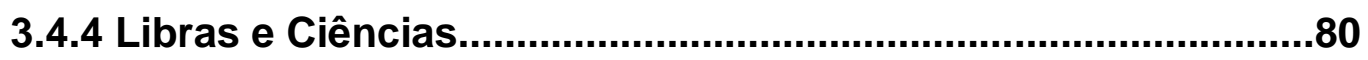

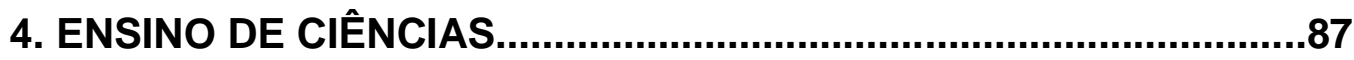

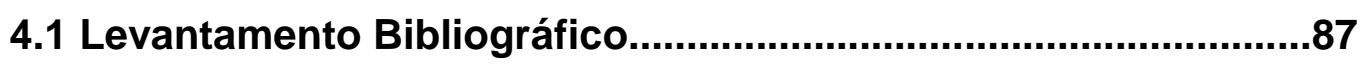

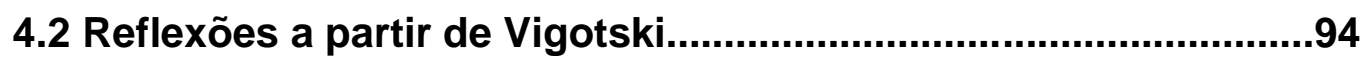

4.2.1 Linguagem, desenvolvimento e cognição.................................94

4.2.2. Do conhecimento à formação de conceitos científicos........100

4.2.3. Defectologia e a visão da surdez..........................................107

5. PROCEDIMENTOS METODOLÓGICOS.......................................111

5.1 Caracterização do ambiente de pesquisa.................................112

5.2 Forma de análise dos resultados..............................................114

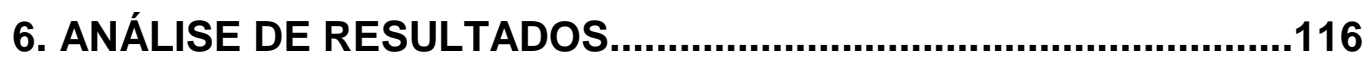

6.1 Descrição da sequência de aulas .............................................116

6.2 Ferramentas utilizadas pelo Professor em suas aulas de

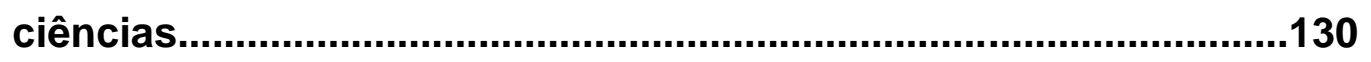

6.3 Interações entre os alunos Surdos e Professor ouvinte no contexto

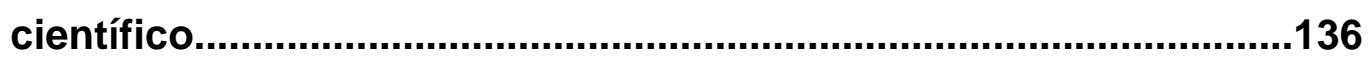

6.4 Atividades avaliativas finais e a inserção dos alunos no contexto de ensino de ciências.................................................140

6.5 Vocabulário científico em Libras..............................................150

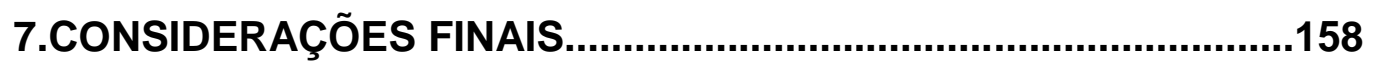

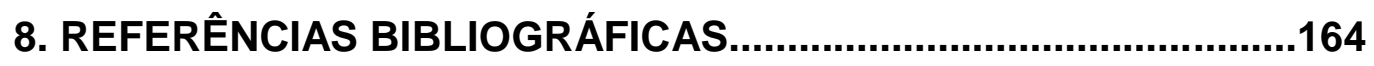

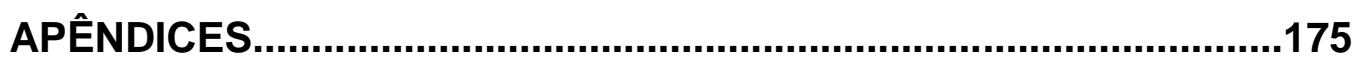




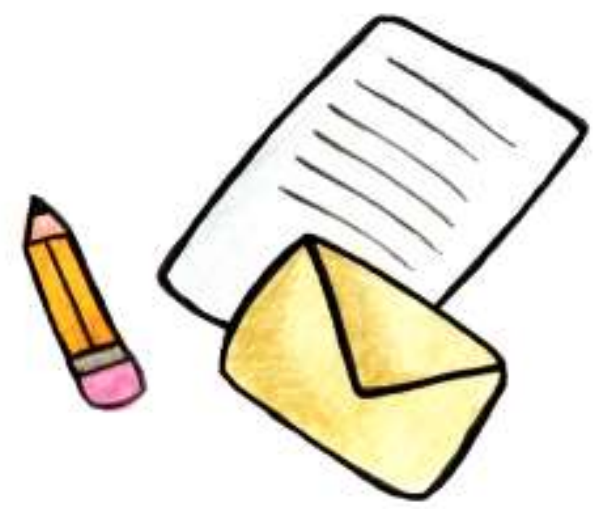

\section{Carta ao leitor}

Caro leitor,

Este trabalho que tem em mãos (ou em uma tela de computador) traz a você uma boa parte dos meus estudos nesses últimos anos, concepções, reflexões e, também, minhas vivências. Mas, antes de falar sobre tudo isso, primeiro, preciso the contar um pedacinho da minha história para que você possa entender o que me motivou a chegar até aqui.

Durante a graduação, no ano de 2011, chegou o momento de escolha da escola para o estágio e, neste dia, foi lançado um desafio: escolher uma escola de educação para Surdos. Até então, nunca antes havia tido um contato tão direto com um Surdo e muito menos com sua língua ou cultura, mas aceitei o desafio sem imaginar o que viria pela frente.

Minha ignorância na área limitava-me a pensar que não havia grandes diferenças entre o ensino de ouvintes e o de Surdos, como, por exemplo, pensava que a leitura e escrita não eram diferenciadas e que a Libras era uma língua universal. Quando percebi que não, pensava que a Libras possuía origem direta do português; concluía que "se o Surdo pode falar através da oralização, então por que não oralizá-lo?" Assim, eu entendia que, nas aulas, caso não houvesse algum termo em Libras, bastava soletrar em português; que 
a escola era extremamente silenciosa; que não existiam deficiências múltiplas. Pouco a pouco, essas minhas ideias foram quebradas por meio de estudos e, principalmente, convivência com os estudantes.

Quando entrei na escola, já conhecia o alfabeto em Libras e acreditava que, assim, eu conseguiria me virar muito bem. Engano brutal! Assim que entrei na escola, os alunos vieram interagir comigo, mexiam tanto as mãos e tão rápido que eu não fazia a menor ideia do que estava acontecendo. Corri para trás da Coordenadora e perguntei: "o que estão querendo?" Ela me respondeu que queriam saber meu nome e meu sinal. Virei-me frente a eles e soletrei meu nome, extremamente insegura e trêmula, e perguntei à Coordenadora o que seria esse "meu sinal". Ela me explicou que cada ouvinte, a partir do momento que entra na comunidade Surda, recebe um sinal próprio, um nome em Libras, e que os alunos estavam querendo me batizar com um nome. Não entendi muito bem, mas aceitei que me dessem um sinal. Os alunos me cercaram, ficaram me olhando e decidiram: esse vai ser o seu sinal! (Figura $\mathrm{x}$ ).

Figura 01: Representação em Libras do meu sinal. Mão aberta com os dedos unidos na região da testa, orientação da palma da mão para baixo, movimento semicircular acompanhando a franja.

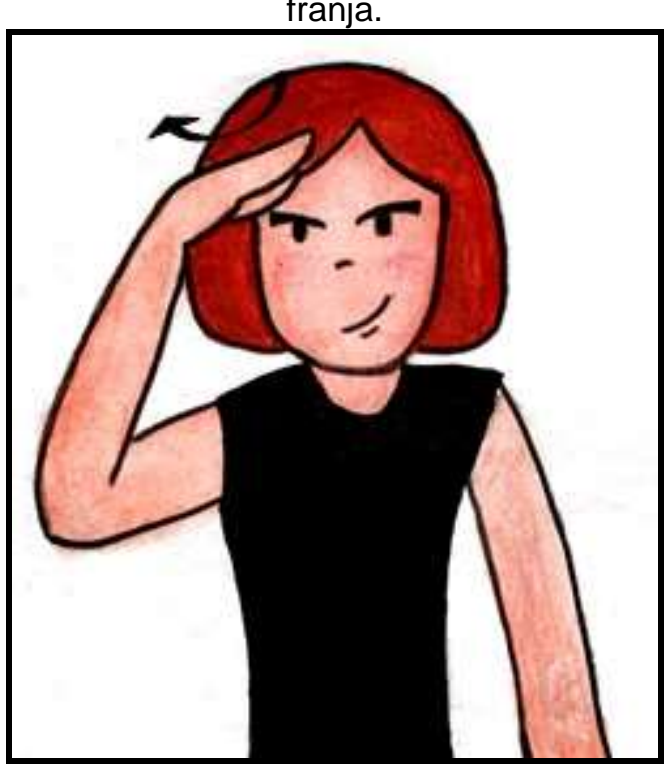

Fonte: Imagem elaborada pela pesquisadora Beatriz Crittelli

Esse sinal representa minha aparência e minha personalidade, é executado no rosto, indicando minha franja, e tem um movimento sutil que reflete minha timidez perante pessoas que não conhecia. Além do mais, a 
configuração de mão inicialmente foi proposta com a letra "B", inicial do meu nome, mas pode ser realizado também com a mão aberta, adequando-se, assim, ao movimento dos sinais sem letras ${ }^{1}$ e não alterando o sentido e significado do sinal.

Assumo que, somente depois de um tempo, percebi o quão importante e marcante foi para mim esse momento, o quanto de significado que esse meu sinal carrega para mim e que, naquele momento, recebi uma marca para minha vida toda.

Ao caminhar nos três módulos de estágio e do curso de Libras, com duração de um semestre cada, minha quebra de concepções se dava de forma muito profunda e constante. Dia-a-dia estava preparada para um novo aprendizado, até chegar o momento em que eu, como estagiária, teria a autonomia de ministrar algumas aulas de ciências para esses alunos.

O momento chegou em conjunto com emoções de nervosismo e entusiasmo, pois eu estava pela primeira vez no papel de ensiná-los, porque, até então, eu estava aprendendo com eles, mas esse ensino em momento nenhum foi desvinculado do quanto eu continuava aprendendo.

A sequência de aulas do estágio foi concluída, mas meu anseio por continuar conhecendo o "mundo das pessoas Surdas" não se encerrou, já que percebi a quantidade de lacunas que existem no ensino de alunos Surdos. Com isso, senti que deveria continuar atuando, através de estudos e, principalmente, de ações.

Dentre o que me incomodava e continua incomodando, encontra-se: a inadequação dos livros didáticos (em particular os de Ciências) às características dos estudantes Surdos; a forma como a Libras e o português são trabalhados de forma distante e pouco significativa; o modo como os professores estão se formando sem a mínima preparação para lidar com esse público, não só preparação, nem ao menos os conhecem; o fato de os recursos didáticos existentes não serem planejados para esses estudantes, distanciando-os do conhecimento científico, e, quando existentes, aplicados de

\footnotetext{
${ }^{1}$ Esse movimento é representado por Surdos militantes que querem cada vez mais desvincular a Libras do português, em que todos os sinais que se configuram com a mão em posição da primeira letra da palavra sinalizada são trocados por outra configuração de mãos.
} 
uma maneira pouco aprofundada e sem adaptações necessárias; dentre outras preocupações.

Com essas inquietações, resolvi me dispor a pensar nesse assunto ainda no período de estágio. Lá, foram desenvolvidos alguns materiais planejados primeiramente para os estudantes Surdos, que depois se tornaram aplicáveis aos demais estudantes.

Ao terminar o tempo de estágio, as inquietações permaneceram. Continuei imersa nesses estudos quando ingressei no mestrado, com o intuito de entender um pouco mais como ocorre a interação entre professor ouvinte e estudantes Surdos nas aulas de ciências, dentro de uma escola bilíngue para Surdos. Percebia que a maioria dos professores das escolas bilíngues de Surdos era ouvinte e, muitas vezes, entrava nas escolas do mesmo jeito que eu entrei, sem saber nada da Libras. Como então esses professores ministravam suas aulas e como os alunos correspondiam a isso? Isso martelava na minha cabeça, mas tive que me focar em um problema específico para estudar porque, além de tudo, ao procurar referências, percebi que existiam, nessa área, lacunas na produção acadêmica que ainda não foram estudadas.

Com isso, fui cada vez mais centralizando o que estudaria para formular minha dissertação e tive de escolher um entre muitos problemas a serem estudados. Assim, consegui manter meu foco em uma escola bilíngue de Surdos, a mesma na qual fiz meu estágio, em um professor de ciências, uma série específica, sétimo ano do Ensino Fundamental II e, dentre essa série, uma turma, o $7^{\circ} \mathrm{C}$. Com esse foco estabelecido, meu intuito foi o de me aprofundar no que acontecia durante as aulas, quais eram as preocupações do Professor, as reações dos alunos, as atividades realizadas, as estratégias metodológicas estabelecidas, as avaliações finais e, também, como os alunos se expressavam nessas avaliações, além se estar sempre atenta à Libras e como ela se constrói nas aulas de ciências.

Durante a prática, na observação das aulas ministradas em Libras, pude compreender as lógicas de raciocínio diferentes e o quanto isso contribui para o aprendizado científico. Aprofundei minhas percepções sobre as demandas dos Surdos no contexto das aulas de assuntos biológicos e, então, decidi continuar desenvolvendo minha pesquisa nesses pontos e, principalmente, 
voltar a dedicar meus estudos à aprendizagem da Libras por acreditar que só com o conhecimento dessa língua eu poderia aguçar meu olhar e minhas análises para fazer um trabalho mais aprofundado.

À medida que me envolvo nesses estudos, minhas inquietações só crescem e me incentivam a tentar preencher as inúmeras lacunas existentes para que esse público alcance seus direitos, dentre eles, o conhecimento científico. Afirmo, também, que esse estudo não para aqui, neste trabalho, pois com certeza precisarei de muito mais pesquisas para conseguir respostas para as inúmeras perguntas que me cercam.

Depois de contar um pouco da minha história, vou falar um pouco das concepções sobre as quais me fundamento para escrever este trabalho.

Acredito quando Santana afirma: "Quando um pesquisador propõe determinadas abordagens para lidar com a surdez, não consegue ser imparcial, pois sua proposta sempre refletirá em uma concepção própria sobre a surdez" (SANTANA 2007, pág 21). A partir dessas concepções, posso afirmar que o presente trabalho se configura a partir de uma abordagem socioantropológica da surdez, por compreender que é uma diferença que deve ser respeitada tanto ao falar do indivíduo Surdo quanto de tudo que o envolve, a língua de sinais, a comunidade Surda e sua cultura e que são válidas todas as suas lutas sociais e políticas exigindo direitos como cidadãos, valorizando suas condições como diferentes.

Para desenvolver o trabalho, adotei a abordagem de pesquisa qualitativa a partir do estudo etnográfico, por envolver um tema que passou a pertencer ao meu contexto de vida e pelo fato de que, cada vez mais pretendo imergir, tanto nos conhecimentos das questões que envolvem a surdez, quanto nas vivências que o aprendizado da língua de sinais e a inserção na comunidade podem me propiciar.

A partir da Convenção da ONU sobre os direitos das pessoas com deficiência, estabeleceu-se um novo paradigma com o termo "pessoa com deficiência" e não mais, "portadores de necessidades especiais", "deficientes", "pessoa com necessidades especiais". Com isso, reconheceu-se que a deficiência é um conceito em evolução, não incorporado de forma pejorativa, pois vem associado à palavra "pessoa", valorizando-o como indivíduo. Assim, 
sigo a redação deste trabalho incorporando o termo "pessoa com deficiência", "pessoa Surda" e "aluno Surdo".

Mesmo de acordo com essa terminologia, pela visão socioantropológica da surdez, os Surdos, apesar de não ouvirem, não são vistos como pessoas com deficiência, já que essa visão revela que, para um ouvinte, não ouvir algum som é uma privação, enquanto que, para o Surdo, o não ouvir é uma condição. Portanto, um sujeito que vive nessa condição é formado com uma identidade própria, não marcada por uma vida que precisa de som e, sim, uma vida constituída plenamente sem o som, sem o foco na "pessoa com deficiência" e sim "pessoa Surda", com uma identidade, uma cultura e uma língua constituída a partir disso.

O termo "portador" também não se aplica porque a deficiência ou a surdez não é algo que um indivíduo porta e sim algo que ele tem e que faz parte dele. Também outro termo constantemente utilizado, "necessidades educacionais especiais", não deve ser aplicado somente à pessoa com deficiência ou à pessoa Surda, pois cada indivíduo, seja ele com ou sem deficiência, se constitui de forma diferente e possui diferentes necessidades educacionais.

A expressão constantemente utilizada neste trabalho, a saber, "Surdo", com a inicial maiúscula, representa uma mudança não só de nomenclatura, mas também uma mudança conceitual ideologicamente marcada. Essa ideia é trazida por Moura (2000) que condiz em não enxergar o Surdo como uma pessoa caracterizada por sua perda auditiva, e sim uma pessoa com uma diferença no que diz respeito à sua condição de pertencer a um grupo minoritário e a ser respeitada por isso.

Este trabalho é dividido em diferentes capítulos, mas a principal divisão é "Ensino de Surdos" e "Ensino de Ciências". Essa divisão representa de fato a união que fiz entre diferentes áreas para escrever este trabalho.

A primeira divisão, "Ensino de Surdos", traz diferentes capítulos e começa por um perfil histórico para que se possa entender quais são as influências e marcas históricas que refletem até os dias de hoje na comunidade dos Surdos.

Sigo pelos capítulos, contando sobre as diferentes abordagens educacionais que os Surdos passaram na escola, sendo elas: Oralismo, 
Comunicação Total e Bilinguismo e, assim como no perfil histórico, as marcas que essas abordagens deixaram na educação até os dias atuais. Ainda no bilinguismo, foi feito um capítulo que reflete um dos pontos chaves desta pesquisa, "interação entre professor e alunos em um contexto bilíngue" e, para finalizar essa parte histórica, explico posteriormente qual é o contexto histórico do Brasil.

Falo também sobre políticas públicas relacionadas à educação de Surdos e, dentro desse capítulo, apresento um panorama do Brasil e do mundo, além de explicar em qual contexto as escolas de Surdos mudaram de nome de "Escolas Especiais" para "Escolas Bilíngues".

Abordo, nos capítulos seguintes, os temas "Cultura Surda e identidade linguística" para entender o quanto que a língua de sinais e surdez contribuem na constituição de um indivíduo e finalizo a parte de educação de Surdos trazendo diversos aspectos da Libras, tais como seus parâmetros; iconicidade e arbitrariedade; fonologia; sintaxe; semântica e classificadores, fechando esse capítulo com uma reflexão acerca do processo de aquisição da língua e relações entre Libras e ciências.

Depois dessa etapa, inicio o capítulo de "Ensino de Ciências" com um levantamento bibliográfico de produções na área e sigo com reflexões a partir de Vigotski, trazendo os aspectos de linguagem, desenvolvimento e cognição. Assim, abordo o processo do desenvolvimento até a formação de conceitos científicos e finalizo com uma breve análise da obra "Defectologia" em relação à visão do autor sobre a surdez.

A pesquisa prossegue com a análise da parte prática que realizei em uma escola bilíngue para Surdos. Começo descrevendo os procedimentos metodológicos para, posteriormente, fazer uma caracterização de como era meu ambiente de pesquisa, explicando como analisei os resultados e, assim, iniciando a análise.

Para entender melhor a análise dos resultados, comecei descrevendo passo a passo como foram as aulas que observei durante o semestre. Sigo a análise de acordo com os objetivos que propus na pesquisa: as ferramentas que o professor utilizou em sala de aula; a interação que ocorria nas aulas de ciências entre o professor ouvinte e os alunos Surdos; explico como foram as 
avaliações finais e o que os alunos apresentaram e, por fim, faço uma reflexão acerca do vocabulário científico na Libras.

Depois de tudo isso, encerro a dissertação com minhas considerações finais a respeito de todo esse processo de pesquisa ao qual me dediquei.

Desejo a você uma ótima leitura! 


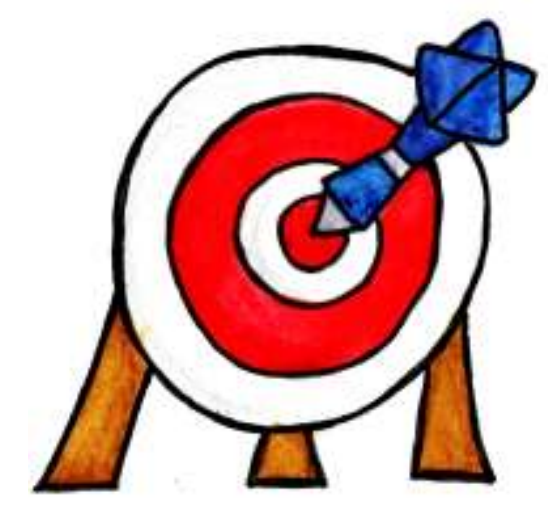

\section{Objetivos}

O objetivo desta pesquisa é estudar a interação entre os alunos Surdos e professor ouvinte pautada no processo de ensino-aprendizagem de ciências e como isso ocorre com o uso da língua de sinais.

Como objetivos específicos, temos:

- investigar como se dá esse processo no contexto de ensino de ciências, especificamente dentro da área de Biologia;

- analisar, através da pesquisa de campo, quais estratégias o professor de ciências utiliza para estimular esse processo em suas aulas;

- analisar, através de vídeos de atividades avaliativas dos alunos, se eles estão conseguindo se expressar com clareza no contexto de ensino de ciências;

- Verificar como o professor lida com a ausência de sinas correspondentes aos termos científicos interagindo com os alunos em Libras. 


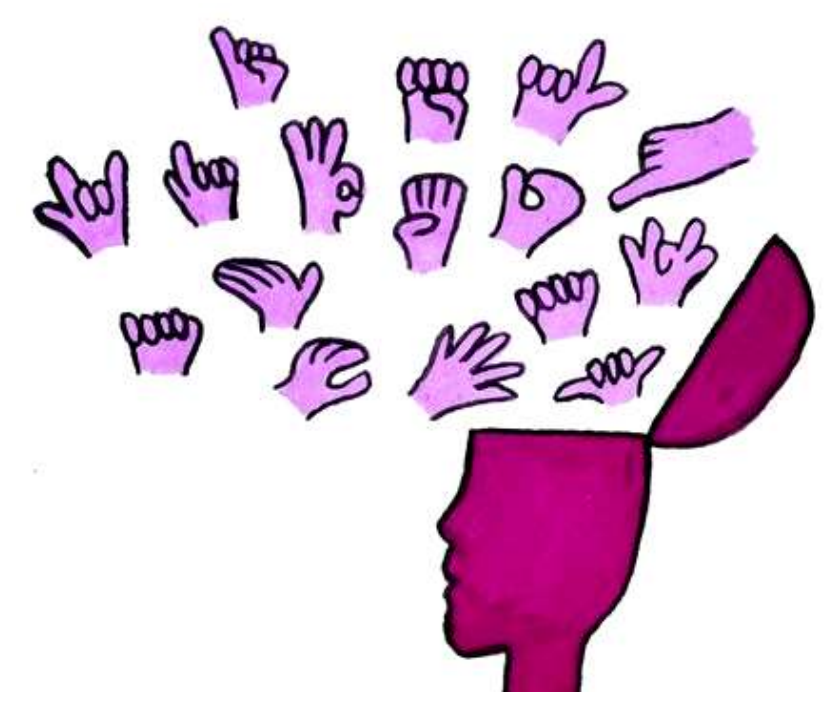

\section{Educação de Surdos}

\subsection{Da antiguidade até os dias atuais}

A educação do Surdo só pode ser compreendida a partir de uma perspectiva mais ampla que abranja a sua história e que mostre quais as fundamentações teóricas, filosóficas, políticas e ideológicas que a embasaram desde o seu início (MOURA, et al., 2005).

Por muitos anos, questionou-se sobre qual seria a maneira mais adequada de ensinar uma pessoa Surda. Algumas evidências históricas indicam os trabalhos pioneiros realizados, mas essa questão continua sem uma resposta.

Dentre as abordagens de ensino de Surdos, duas se destacam: a concepção oralista e o bilinguismo. A primeira concepção, que segue o modelo clínico-patológico, está baseada na ideia de que o sujeito Surdo deve ser "normalizado" por meio da linguagem oral, recorrendo, para isso, às 
tecnologias disponíveis com o intuito de possibilitar a audição, mesmo que seja parcial. A abordagem do bilinguismo parte do pressuposto de que a língua de sinais é prioritária para o Surdo e que essa característica está associada a uma cultura específica (SANTANA, 2007). De acordo com Santana (2007), esse embate se dá "entre a área da saúde (que busca 'normalizar') e a área pedagógica (que procura diminuir os 'estigmas') ".

De acordo com Moura et al. (2005), a história da língua de sinais e educação de Surdos foi construída desde tempos antigos e pode ser dividida em Antiguidade (4000 a.C. - 476 d.C.); Idade média (476 - 1453); Idade moderna (1453 - 1789); Idade contemporânea (1789 - 1900), até os dias atuais.

Outros autores da área fazem a divisão histórica com nomes e datas diferentes. Essa pesquisa se atém a divisão do tempo de acordo com Moura et al. (2005).

A Antiguidade foi marcada pela caracterização do sujeito Surdo como uma pessoa incapaz de pensar e aprender por não conseguir desenvolver a fala, desabilitando-o a gerir suas próprias vidas, sem a reflexão de que a comunicação poderia ser estabelecida de outras maneiras (MOURA et al., 2005). Para os romanos, os Surdos não tinham a possibilidade de desenvolvimento moral e intelectual, portanto, não poderiam ser educados. Já na Grécia, em uma época em que se valorizava o intelectual, eram considerados insensíveis, sem raciocínio e denominados "não-humanos" pelo fato de não falarem (COSTA, 2010). De acordo com Costa (2010), nos textos do Antigo Testamento bíblico, a pessoa com deficiência era tida como subnormal, rejeitada por despertar o medo nas pessoas e para prevenção de um possível contágio, porém, Benvenuto (2006) afirma que Jesus, através da reintegração que fez do aleijado na comunidade, trouxe o assunto da consciência ética e espiritual do indivíduo. Essa visão de Jesus em relação às pessoas com deficiência, na Bíblia, pode ser observada em diversos trechos. A seguir, destaco um deles:

Ao passar, Jesus viu um cego de nascença. Seus discípulos the perguntaram: "Mestre, quem pecou: este homem ou seus pais para que ele nascesse cego? Disse Jesus: "Nem ele nem seus pais pecaram, mas isso aconteceu para que a obra de Deus se manifestasse na vida dele" (BÍBLIA, João 9, 1-3). 
Assim como na passagem do aleijado, nesta passagem, Jesus mostra a deficiência não como um pecado ou um erro, nem como resultado de um pecado familiar, e, assim, quebra a crença de que não havia sofrimento ou castigo sem iniquidade. Além de quebrar essa crença, revela que a obra de Deus se manifesta na vida do homem cego, dando visibilidade a ele e tirando da posição de marginalidade que se encontrava.

De acordo com Moura et al. (2005), não há indicações de existir uma língua de sinais nessa época, porém, mesmo nos dias atuais, é possível observar comportamentos e estigmas desvalorizando da mesma maneira o sujeito Surdo.

Afirma Capovilla (2000), que a falsa crença de que a única forma de linguagem é a falada, originada na antiguidade, foi disseminada até o início da década de 1960, sendo possível, assim, entender os preconceitos que até hoje perseguem as pessoas Surdas. Pode-se afirmar que, nesse período, a posição do sujeito Surdo perante a sociedade era relacionada somente à sua incapacidade (REILLY, 2007).

Na Idade Média, os Surdos continuaram a ser desvalorizados por não conseguirem "falar os sacramentos". A surdez era assemelhada à loucura, mas congregações religiosas que seguiam os votos de silêncio de "Saint Benoit" os adotavam (COSTA, 2010). Nessas congregações, os monges se comunicavam por meio de "signos", com sinais de comunicação e de letras do alfabeto, entretanto, Reilly (2007) afirma que a origem da língua de sinais não se encontra nos sinais monásticos, pois estes tinham um léxico insuficiente e sintaxe não equivalente. No entanto, a prática de utilização de sinais entre os monges contribuiu para perceberem que a comunicação por sinais constituía uma forma eficaz de comunicação, levando ao desenvolvimento de meios para ensino dessa prática de comunicação em sinais.

$\mathrm{O}$ século XVI foi marcado pelo surgimento de algumas iniciativas isoladas de ensino para Surdos as quais foram, depois, institucionalizadas, contribuindo para a mudança de visão do Surdo como um sujeito incapaz de aprender e desenvolver pensamentos (COSTA, 2010).

Não se tem um registro preciso de quem foi o primeiro educador de Surdos, porém, se destaca uma iniciativa para a educação dos Surdos com o uso da língua de sinais e língua oral, através de Bartolo della Marca d' Ancona, 
no século XIV, sendo um trabalho árduo e demorado já que eram fortes e predominantes as ideias de incapacidade dos Surdos (MOURA et al., 2005 apud SKLIAR, 1996).

A partir do século $\mathrm{XVI}$, a posição do Surdo passa por um processo de deslocamento de concepções que o associavam a incapacidades para a ideia do Surdo como um ser educável. $O$ trabalho que possui maior reconhecimento como sendo pioneiro é de Pedro Ponce de León (1520 -1584), na Idade Moderna, sendo este um professor de Surdos que os ensinava a ler, escrever e falar, quebrando todas as crenças religiosas, filosóficas e éticas que até então estigmatizavam a pessoa Surda como incapaz. Porém, esse trabalho levantou bases para iniciar e desenvolver cada vez mais uma abordagem oralista entre os demais professores de Surdos que surgiam nesse período (MOURA et al., 2005). Tanto Pedro Ponce quanto outros educadores da época utilizavam língua de sinais para iniciar 0 trabalho com pessoas Surdas ao desenvolvimento da fala, porém, quando esse estágio de fala era alcançado, a língua de sinais era abandonada porque acreditavam que poderia prejudicar 0 desenvolvimento posterior de fala (Moura et al., 2005).

Ainda na Idade Moderna, Charles-Michel de L'epée (1712 - 1789) trabalhou com pessoas Surdas priorizando a língua de sinais na educação como uma forma plena de comunicação, trabalhando com a visão de que o sujeito Surdo era passível de humanidade e de adquirir conhecimentos sem ser necessária a fala (MOURA et al., 2005). Ele estudou a língua de sinais já utilizada pelos grupos de Surdos, atentando-se às suas características linguísticas e verificando que a comunicação se apoiava no canal viso-gestual (LACERDA, 1998). A partir disso, L'epée fundou o Instituto Nacional de SurdosMudos de Paris, em 1760, onde ampliou métodos de aprendizagem da língua de sinais e, a partir dessa língua, desenvolveu a leitura e escrita da língua francesa do grupo socialmente majoritário. Com o passar dos anos, alunos Surdos que correspondiam bem ao método trabalhavam como professores dos novos alunos Surdos (LACERDA, 1998).

De acordo com Costa (2010), em um tempo no qual a fala oral era valorizada para que o Surdo fosse aceito socialmente, os denominados gestualistas, que valorizavam a comunicação dos Surdos através dos movimentos das mãos, corpo e cabeça para exprimir suas ideias, 
consideravam a língua de sinais como forma eficiente e eficaz para abrir portas ao conhecimento. A educação de Surdos foi essencial para começar uma mudança de visão de sujeito perante a sociedade, porém, o peso da anormalidade continuava (COSTA, 2010).

Essa foi considerada a época de ouro para os Surdos. Apesar de o abade Charles M. de L'Epeé ter sido muito criticado por sua maneira de trabalhar, deve-se destacar a ascensão que ele propiciou aos Surdos e à língua de sinais, valorizando-os perante a sociedade que até então os depreciava (MOURA et al., 2005).

A Idade Contemporânea foi marcada pela expansão da língua de sinais pela Europa e chegando à América, primeiramente nos Estados Unidos. A partir do século XVIII, houve uma grande disputa de "gestualistas versus oralistas". A disputa ocorria entre a valorização e expansão da língua de sinais contra o oralismo que a considerava incompleta, priorizando a articulação de palavras, leitura e escrita. Os estudiosos e defensores dessa vertente eram partidários da eugenia, lutando para a "melhoria da raça humana" a partir da exclusão das diferenças (MOURA et al., 2005).

No ano de 1880 , foi realizado o II Congresso Internacional sobre a Instrução de Surdos em Milão, onde uma maioria adepta à abordagem oralista se fortaleceu. Apresentaram Surdos que realizavam bem a fala oral para mostrar a eficiência dessa abordagem e lá foi votada a implantação obrigatória do oralismo e a total extinção do que chamavam de "linguagem gestual" (LACERDA, 1998). Essa abordagem não foi questionada e prosseguiu por quase um século.

A Idade Atual, iniciada a partir do ano de 1900 (MOURA et al., 2005), começou sendo marcada pela predominância do oralismo e, novamente, pela desvalorização da língua de sinais, espalhando-se por toda a Europa e demais países influenciados pelas abordagens e estudos de educação para pessoas Surdas.

Ao longo dos anos, a educação de Surdos transitou por diferentes abordagens: o oralismo, a comunicação total e o bilinguismo. 


\subsubsection{Oralismo}

O oralismo se caracterizou pela visão de que o sujeito Surdo deve falar e não gesticular (como antes era denominada a sinalização), baseando-se em um modelo clínico terapêutico da surdez como uma patologia que poderia ser curada e tratada através da fala, leitura orofacial ${ }^{2} \mathrm{e}$, mais tarde, próteses e implantes, buscando normalizar o sujeito Surdo. Este era também colocado em posição inferior ao ouvinte, destacando sua incapacidade auditiva.

Essa abordagem foi desenvolvida na Alemanha, por Heinicke, em um contexto de supervalorização da língua alemã como idioma único no país e nacionalismo exacerbado desde o final do século XIX, quando os que eram considerados fracos ou diferentes não tinham espaço na sociedade, uma vez que era enfatizada a busca de uma identidade cultural única e padronizada. Com isso, os Surdos se esconderam e se isolaram, perdendo consequentemente sua participação política, sua cultura e identidade (CAPOVILLA, 2000).

A proibição da língua de sinais foi marcada pelo Congresso de Milão, em 1880, reunindo educadores de Surdos, principalmente da França e Itália. Nesse congresso, foi excluída a ideia de se utilizar sinais como apoio para a oralização dos alunos Surdos e foi proposta a erradicação da língua de sinais na educação para a implantação da fala e leitura orofacial (MOURA et al., 2005).

Com isso, a educação de Surdos limitou-se ao ensino da oralização, a língua de sinais foi eliminada das instituições de ensino, os professores Surdos foram expulsos e a comunidade Surda foi extremamente prejudicada por ter sido excluída das políticas das instituições de ensino. Todas essas medidas foram tomadas porque tais fatores eram considerados um risco para $O$ desenvolvimento da linguagem oral (CAPOVILLA, 2000 apud SACKS, 1990)

\footnotetext{
${ }^{2} \mathrm{O}$ termo "leitura orofacial" refere-se à leitura da fala oral através da articulação facial realizada pelos Surdos como um dos métodos de trabalho na oralização. Nesse método, os indivíduos utilizam diferentes estratégias para compreender a fala: atenção voltada para diferentes expressões faciais, reconhecimento de pistas por gestos, atenção para aspectos relacionados ao ambiente, entre outras (DELL'ARINGA et al., 2007).
} 
Essa abordagem foi implantada em escolas e, com ela, a língua de sinais foi desvalorizada e proibida na Europa, pois, com o domínio da fala por parte dos Surdos, estudiosos afirmavam que ela não era mais necessária.

Nesse período, não se levava em consideração se esse processo era forçoso ao indivíduo Surdo ou mesmo inadequado à sua educação escolar, simplesmente era imposto, afinal, é mais fácil impor que a minoria aprenda a língua da maioria, não o contrário. Dessa forma, acreditava-se que o sujeito Surdo poderia ser incluído na sociedade e que essa era a melhor maneira para ele aprender e se desenvolver.

Com a ascensão do oralismo, os Surdos não eram vistos como uma população com cultura própria, mas houve novamente uma ênfase nas deficiências, destacando suas "incapacidades" (CAPOVILLA, 2000). A partir dessa priorização de destacar o sujeito Surdo como deficiente, o objetivo do oralismo era desenvolver a pessoa Surda do modo mais próximo possível do "normal", de modo que ela pudesse interagir como um membro produtivo no universo ouvinte emocional, social e cognitivamente (CAPOVILLA, 2000).

Mesmo com tais objetivos e imposições, algumas pesquisas entre as décadas de 1960 e 1970 indicavam que tal método não estava sendo eficaz e nem trazendo bons resultados escolares. Capovilla (2000) afirma que tanto a leitura quanto a escrita dos alunos encontravam-se em níveis insatisfatórios e, principalmente, a leitura labial dos alunos era deficitária. Consequentemente, esses índices também apareciam nas matérias escolares em diferentes áreas do conhecimento.

Os objetivos educacionais do oralismo estavam longe de ser alcançados, pois os alunos Surdos apresentavam um baixo índice de aprendizado, tanto para as disciplinas escolares quanto para a leitura e escrita. Isso gerou uma baixa expectativa de sucesso dessa abordagem, uma vez que os casos de alunos bem-sucedidos deveriam se tornar regra e não exceção, ou então estudiosos da área deveriam pesquisar outras maneiras de ensino para os Surdos (CAPOVILLA, 2000).

Nessa época de queda do oralismo, meados da década de 1960, surgiram tecnologias, principalmente com uso de aparelhos auditivos, para possibilitar a oralização. Porém, mesmo com essas tecnologias, o objetivo de 
permitir ao sujeito Surdo a aquisição e o desenvolvimento de uma língua (no caso a língua oral) ainda estava longe de ser alcançado (CAPOVILLA, 2000).

\subsubsection{Do Oralismo para a Comunicação Total}

Como oposição ao movimento oralista, algumas pessoas, entre elas familiares de Surdos, estudiosos e professores, ainda reconheciam que a língua de sinais tinha seu valor e que era fundamental para o desenvolvimento da pessoa Surda, reconhecendo que a língua oral não é a única forma de linguagem. Cresce, então, na década de 1970, um movimento de ascensão da língua de sinais que, na época, ainda não era reconhecida como língua, mas como linguagem (LACERDA, 1998).

Para explicar essa abordagem, darei um exemplo de sala de aula contendo uma professora com uma maioria de alunos ouvintes em sua sala, porém, também com alguns alunos Surdos. Para não excluir nenhum aluno, ela ministrava suas aulas oralmente, com amplificação da voz, e, ao mesmo tempo em que falava, sinalizava com as mãos a língua de sinais, alfabeto datililógico, utilizando gestos, outras formas de expressões e recursos visuais. Assim, em teoria, alunos Surdos e ouvintes estariam compreendendo o que ocorre, pois as duas línguas se expressam concomitantemente.

Foi somente com Stokoe (1960), em seus estudos de linguística da língua de sinais, e com demais pesquisadores da área que a abordagem oralista cedeu lugar para a comunicação total. A partir disso, a língua de sinais passou a se desenvolver com a incorporação de novos sinais, porém, procuravam com isso aumentar a visibilidade da língua falada, tornando-a mais acessível ao Surdo e, de fato, essa abordagem obteve uma grande vantagem em comparação ao oralismo (CAPOVILLA, 2000).

Como um aspecto importante dessa nova abordagem educacional, destaca-se que a comunicação total abarcava toda a possibilidade de comunicação, língua oral, leitura orofacial, língua de sinais, e sistemas artificiais também, como alguns tipos de gestos, acreditando-se, assim, que 
isso garantia uma comunicação plena e abrangente pelos diversos meios utilizados (CAPOVILLA, 2000; LACERDA 1998).

O objetivo da Comunicação total era oferecer ao Surdo uma possibilidade de comunicação com ouvintes e outros Surdos, sendo que a oralização não era seu foco, porém, era também trabalhada para possibilitar uma integração social (LACERDA, 1998). Nessa abordagem, era previsto utilizar tanto sinais retirados da língua de sinais quanto utilizar sinais gramaticais modificados, marcadores que se encontram na língua falada, configurando-se de forma que tudo o que era falado era acompanhado por elementos visuais representativos de acordo com cada palavra, algo que acreditavam facilitar a aquisição da língua oral, leitura e escrita (MOURA et al., 2005).

Essa proposta surgiu como uma quebra do oralismo, contra a imposição de uma aprendizagem forçosa à pessoa Surda e com a volta da língua de sinais, porém, não como língua principal, e sim como estratégia de ensino. Mas essa abordagem não se perpetuou por muito tempo porque, mesmo com esses pontos positivos, ela não respeitava a estrutura linguística e gramatical da Língua de Sinais, pois não trabalhava as duas línguas com estruturas diferentes, mas havia uma imposição da estrutura linguística da língua oral sobre a língua de sinais.

A Língua de Sinais não é uma língua correspondente a uma língua oral, é uma língua própria, com estrutura própria. Quando uma pessoa se dispõe a falar uma língua oral e, ao mesmo tempo usar a língua de sinais, ela deve seguir uma estrutura gramatical de apenas uma das línguas, porque não tem como fazer com que o cérebro raciocine em duas línguas de modalidades diferentes ao mesmo tempo.

Ademais, ao submeter as crianças à aquisição de língua oral e língua de sinais concomitantemente (ao mesmo tempo), uma língua sempre se sobrepõe à outra. No caso, a língua oral (que é a língua materna de um professor ouvinte) é a língua que predominava nas aulas em comparação à língua de sinais, levando as crianças Surdas a passarem por um aprendizado errôneo da língua de Sinais tornando as crianças "hemi-língues" (CAPOVILLA, 2000) sem o domínio da língua oral e nem da língua de sinais. 
Lacerda (1998) afirma que a comunicação total, de fato, favoreceu os Surdos de maneira efetiva porque Ihes propiciou o contato, aprendizagem e desenvolvimento dos sinais, proibidos desde a época do oralismo, que nessa abordagem poderiam ser trabalhados na escola e ser utilizados em outros espaços também. Foi uma abordagem que apresentou muitos problemas, no entanto, contribuiu para a volta da língua de sinais e abriu espaço para o desenvolvimento de uma nova abordagem, a bilíngue.

\subsubsection{Bilinguismo como outra forma de enxergar sujeito e língua}

A abordagem bilíngue contrapõe-se ao oralismo porque prioriza o canal viso-espacial como fundamental para a aquisição de linguagem da pessoa Surda. Além disso, se contrapõe à comunicação total por defender um espaço real para a língua de sinais durante 0 trabalho de desenvolvimento educacional. Assim, defende que cada uma das línguas trabalhadas com 0 aluno Surdo "mantenha suas características próprias e que não se 'misture' uma com a outra" (LACERDA, 1998).

$O$ intuito da educação bilíngue é que $O$ aluno Surdo tenha um desenvolvimento cognitivo-linguístico que possa ser equivalente ao que ocorre com o aluno ouvinte, permitindo que, fora do espaço escolar, esse indivíduo desenvolva uma relação com ouvintes, por ter acesso às duas línguas durante seu período de escolarização (LACERDA, 1998).

O bilinguismo é a abordagem utilizada atualmente no Brasil, considerada a mais adequada para o aluno Surdo, hoje. Especificamente o capítulo VI do Decreto lei número 5.626, "Da garantia do direito à educação das pessoas Surdas ou com deficiência auditiva", indica o direito dos alunos Surdos à educação em escolas bilíngues ou, também, a haver intérpretes nas salas (educação inclusiva) traduzindo as aulas, especificando essa abordagem no parágrafo $1^{\circ}$ : 
$\S 10$ São denominadas escolas ou classes de educação bilíngue aquelas em que a Libras e a modalidade escrita da língua portuguesa sejam línguas de instrução utilizadas no desenvolvimento de todo o processo educativo (Brasil, 2005).

Portanto, a escola estruturada conforme o decreto deve ter suas aulas todas ministradas em Libras, como língua principal, tendo a língua portuguesa como língua dois e em sua modalidade escrita somente.

Referente à abordagem bilíngue, Godfeld (2001, p. 39) afirma: "O bilinguismo tem por pressuposto básico que o Surdo deve ser bilíngue, ou seja, deve adquirir como língua materna a língua de sinais, que é considerada a língua natural dos Surdos" (GODFELD, 2001).

Com essa proposta, a língua de sinais é trabalhada como língua principal nas aulas - L1, e o português como língua secundária - L2. Isso permite que o aluno esteja em contato com as duas línguas, priorizando sua língua materna e trabalhando com a língua oral, o português, da maneira que esteja ao seu alcance, na leitura e escrita.

Em salas de aula comuns, o aluno Surdo conta com um intérprete para realizar esse trabalho de inclusão. Enquanto o professor explica o conteúdo oralmente, o intérprete traduz a explicação em língua de sinais para o aluno Surdo. Essa abordagem possibilita também que o estudante tenha contato com adultos Surdos, sejam eles professores da escola ou instrutores, permitindo a construção de uma "auto-imagem positiva como sujeito Surdo", não excluindo a possibilidade de integrar-se numa comunidade de ouvintes pelo contato com outros funcionários, familiares, colegas Surdos e outras pessoas de seu convívio (LACERDA 1998).

Além dos adultos Surdos, o contato dos alunos Surdos entre pares é um ponto forte para o desenvolvimento da comunicação em suas relações de amizade e conversas corriqueiras, ou seja, em tudo isso a língua se desenvolve, propiciando a ampliação do vocabulário. Também em sala de aula, o diálogo entre os colegas falantes da mesma língua desempenha um importante papel nas relações de aprendizagem.

Porém, existem escolas específicas para alunos Surdos, nas quais o trabalho com base no bilinguismo é realizado pelo próprio professor, que deve ministrar as aulas em Libras, sendo este bilíngue. 
De acordo com Lacerda (1998), os alunos Surdos devem ser expostos o mais cedo possível à língua de sinais para que o desenvolvimento linguístico e as interações possam fluir, podendo levá-los a sinalizar tão rapidamente quanto os ouvintes aprendem a falar. A autora firma que:

(...) ao sinalizar, a criança desenvolve sua capacidade e sua competência lingüística, numa língua que Ihe servirá depois para aprender a língua falada, do grupo majoritário, como segunda língua, tornando-se bilíngüe, numa modalidade de bilingüismo sucessivo (Lacerda, 1998).

Porém, a pesquisadora ressalta que essa situação não pode ser comparada à de quem tem pais que falam duas línguas orais diferentes, porque, nesse caso, os filhos aprendem as duas línguas usando o canal oralauditivo num contexto denominado "bilinguismo contemporâneo". Já no que se refere às crianças Surdas, ocorre a aprendizagem de duas línguas que envolvem diferentes canais de comunicação: oral-auditivo e viso-espacial (LACERDA, 1998).

A proposta do bilinguismo não é somente uma mudança metodológica, mas ela acompanha uma mudança ideológica em que a pessoa Surda passa a ser valorizada por meio da priorização da sua língua materna em sala. Nessa abordagem educacional, a língua de sinais não é utilizada simultaneamente como na comunicação total, mas é priorizada, respeitada em sua estrutura gramatical, enquanto que a língua oral é trabalhada somente nas modalidades não sonoras, tirando também o objetivo de levar a pessoa Surda a falar oralmente, como na abordagem oralista, deixando o sujeito Surdo livre e oferecendo-Ihe possibilidades para aprender e se desenvolver com a língua de sinais (CAPOVILLA, 2000). 


\subsubsection{O professor e o aluno Surdo no contexto bilíngue}

Entre o professor e o aluno Surdo, muitos fatores existem e podem interferir de maneiras positivas ou negativas nas aulas, a depender de como 0 professor realiza seu trabalho. Tais fatores vão além de uma língua diferente a ser contemplada, pois envolvem uma cultura diferente, representações diferentes e até uma estrutura semântica diferente entre as línguas que devem ser levadas em consideração ao se planejar uma aula. Esses temas serão abordados mais especificamente nos próximos capítulos.

A interação que ocorre entre o professor e o aluno Surdo é expressa de formas diferentes de acordo com três possíveis modelos de escolas no município de São Paulo: o das escolas bilíngues de educação de Surdos onde o público de alunos Surdos é prioritário; o das escolas com salas comuns onde tal público é minoria e se encontra dentro de um contexto de inclusão; ou o das escolas polos onde $\mathrm{O}$ atendimento com alunos Surdos ocorre em salas bilíngues, denominadas SAAI - Salas de apoio e acompanhamento à inclusão, com professores especializados para esse atendimento.

$O$ verbo incluir tem origem no latim includere e significa: conter, compreender, fazer parte, participar. Essa prática, refletida na educação inclusiva, leva os profissionais da área à reflexão sobre as escolas já existentes como um lugar de convivência comum a todos e que estabelece propostas de construção de um projeto pedagógico visando ao respeito às especificidades que cada deficiência agrega, com ênfase na interação social em diferentes áreas do conhecimento (BOBBIO, 2004).

As escolas bilíngues de educação de Surdos são formadas prioritariamente por estudantes Surdos, porém, a maioria dos professores é composta por ouvintes. O professor que se encontra nesse contexto escolar deve planejar suas aulas explorando ao máximo o aspecto visual, utilizando materiais didáticos, vídeos e imagens, pelo fato de os alunos se apoiarem em uma comunicação em língua de sinais que se configura de forma visualespacial, diferente da língua portuguesa, por exemplo, que é oral-auditiva ( $\mathrm{CHOI}$ et al., 2011). No entanto, o ensino não deve ser limitado somente ao estímulo de recursos visuais. Como defende Tavares e Camargo (2010 apud 
SOLER, 1999), recursos multissensoriais para alunos com deficiência ou Surdos podem se enquadrar de maneira muito positiva nas aulas, estimulando os alunos em seus diferentes sentidos e enriquecendo seu aprendizado.

As escolas bilíngues possuem também profissionais denominados "instrutores", prioritariamente Surdos, e que realizam esse papel de mediação entre o professor ouvinte e o aluno Surdo. Os instrutores podem acompanhar as aulas e auxiliar, principalmente, os professores que estão em fase de aprendizado da língua de sinais.

\subsubsection{Contexto histórico da Educação de Surdos no Brasil}

Em 1857, E. Huet, Surdo, fundou, no estado do Rio de Janeiro, o Imperial Instituto de Surdos-Mudos, que atualmente é denominado INESInstituto Nacional de Educação de Surdos, iniciando-se somente para meninos (COSTA, 2010; ALBRES, 2005). Ao fundar o Instituto, Huet trabalhava com os alunos a língua de sinais francesa, porém, esse agrupamento de Surdos em um instituto resultou mais tarde na fundamentação e desenvolvimento da Libras - Língua brasileira de sinais, e na possibilidade de que os Surdos pertencessem a uma comunidade que compartilhava suas vivências e dificuldades perante a sociedade (COSTA, 2010).

No Instituto, o currículo escolar era desenvolvido em salas com um número reduzido de alunos e por meio de métodos especiais que tinham como propósito levar o Surdo a adquirir consciência da linguagem e do ritmo da fala. Para isso, eram necessários oito anos de educação específica, além de diferentes atividades extracurriculares, como, por exemplo, oficinas preparatórias para o mercado de trabalho nas seguintes áreas: mecânica, alfaiataria, tornearia, carpintaria, artes gráficas (ALBRES, 2005).

Entre os programas de ensino de Huet, estão as disciplinas "Linguagem articulada" para trabalhar através de diversos métodos a oralização dos Surdos e "Leitura sobre os lábios", treinando leitura labial, revelando que o Instituto apresentava um foco específico no trabalho de oralização de seus alunos 
Surdos. Entretanto, em 1867 (COSTA, 2010 apud ROCHA, 1997), houve uma mudança no quadro de funcionários do Instituto e, consequentemente, essas disciplinas foram extintas, dando lugar à Leitura, Escrita, Doutrina Cristã, Aritmética, Geografia com ênfase no Brasil, Geografia Elementar, Elementos da História, Português, Francês e Contabilidade.

A disciplina "Leitura sobre os lábios" volta no ano de 1873, junto da criação de uma nova função, o "professor repetidor", que assistia e repetia as lições dos professores em cada disciplina visando à "desmutização" dos alunos Surdos. Além disso, o ensino no instituto, de uma maneira geral, volta-se para a área profissional (COSTA, 2010 apud ROCHA, 1997).

Ao longo dos anos, por meio de relatórios gerados no instituto acerca da evolução dos alunos, foi ficando evidente que o oralismo era uma abordagem falha e, aos poucos, a língua de sinais foi sendo resgatada, primeiramente por meio da soletração manual do alfabeto (que só era possível para crianças alfabetizadas no português), mas ainda com a finalidade de uma oralização do Surdo (COSTA, 2010).

A língua de sinais, que até então era denominada mímica, era indicada por médicos para ser substituída pela soletração manual do alfabeto. Porém, indicavam ser um trabalho árduo porque acreditavam que havia uma "contaminação mímica", pois, em poucas horas, os Surdos já podiam se comunicar através desse meio que consideravam "instintivo e deficiente", uma vez que consideravam os sinais uma "enfermidade passível de cura", sendo a cura o uso da língua oral, algo correto e dentro do que estipulavam como um padrão de normalidade (COSTA, 2010).

Em 1957, o Imperial Instituto dos Surdos-Mudos oficialmente altera seu nome para Instituto Nacional de Educação de Surdos - INES, pela Lei oㅡ 3.198, de 6 de julho de 1957, sendo este um espaço rico para o desenvolvimento e construção da Língua de Sinais própria do país (ALBRES, 2005).

Na década de 1960, o INES já não era a única escola destinada ao público de Surdos, específica da Educação Especial, porque dentro desse período houve a criação da APAE - Associação de Pais e Amigos dos Excepcionais, do Instituto Pestalozzi e de diversas escolas especiais para Surdos espalhadas pelo Brasil. Com isso, o Ministério da Educação - MEC foi 
impelido a orientar a proposta curricular para os Surdos que deveria ser colocada em execução por todo o país (ALBRES, 2005).

A língua de sinais, por ser espaço-visual, muitas vezes não é aceita, pois carrega a essência da diferença. Embora, na Conferência da Unesco, em 1951, tenha sido determinado que a pessoa tem o direito de ser educada em sua própria língua, mesmo que esta seja diferente da língua majoritária do país, seguindo a proposta educacional bilíngue (ALBRES, 2005).

O espaço escolar dos Surdos é, também, um espaço de luta, pois mesmo na década de 1980, com o MEC elegendo o oralismo como abordagem mais adequada para a educação de Surdos, as escolas começaram o rompimento a partir do desenvolvimento de trabalhos cuja abordagem era a comunicação total (ALBRES, 2005). De acordo com Albres (2005), hoje, os documentos do MEC nos trazem o bilinguismo, porém, em algumas escolas, as práticas permeiam tanto métodos e técnicas oralistas da comunicação total e do bilinguísmo. Essa mescla pode ser encontrada devido ao quadro de funcionários das escolas que viveram em distintas épocas, pois, em um curto período de tempo, o que se considerou a melhor abordagem para se trabalhar com um Surdo variou fortemente, não havendo consenso.

Cabe destacar que a escola tem uma forte participação no movimento de transformação da sociedade a fim de ocorrer mudanças necessárias para garantir o acesso à educação para todos. A educação de Surdos também não está fora dessas mudanças e, ao passar pelas diferentes abordagens educacionais, conclui-se que a garantia de acesso ao saber e do exercício crítico da cidadania aos alunos se dá principalmente pelo desenvolvimento da linguagem (ALBRES, 2005). Como garantir a aquisição e acesso da linguagem ao Surdo da melhor forma é uma questão que continua em estudo. Todo o caminho trilhado até então ajudou a saber o que não deve mais ser propagado, orientando futuros pesquisadores aos próximos passos e, assim, caminhando para que, um dia, tal questão seja sanada. 


\subsection{Políticas públicas relacionadas à educação de Surdos}

A luta das pessoas com deficiência, bem como a dos Surdos, foi sendo reconhecida cada vez mais na sociedade, ganhando pouco a pouco espaços nas políticas e levando ao surgimento de leis específicas. A análise das principais políticas que envolvem a Educação Especial será apresentada no âmbito das políticas internacionais, chegando até os principais aspectos que permeiam as políticas nacionais.

\subsubsection{Panorama Nacional e Internacional}

No âmbito das políticas internacionais, destacam-se as publicadas pela Unesco que são relacionadas aos direitos das pessoas com deficiência: Declaração de Salamanca sobre princípios, Política e práticas na área das necessidades educativas especiais (1994); Declaração Mundial sobre educação para Todos (1990) e a Declaração da Guatemala (2001).

A Declaração de Salamanca (UNESCO, 1994) explicita que toda criança tem o direito à educação em escolas comuns tendo, com isso, a "oportunidade de manter um nível aceitável de aprendizagem" e que as características diferenciadas dos alunos e suas necessidades devem ser contempladas pelo sistema educacional. Esse mesmo documento escreve um apelo à comunidade internacional e governos para que propiciem que toda proposta descrita seja executada.

A Declaração Mundial sobre Educação para todos (UNESCO, 1990) está dividida em dez artigos que explicitam seus objetivos. Dentre eles, destaca-se: contemplar as necessidades de aprendizagem e concentrar a atenção nisso, promover a igualdade, propiciar um ambiente adequado à aprendizagem, mobilizar recursos, desenvolvendo uma política contextualizada de apoio e, enfim, fortalecer a solidariedade internacional. Em resumo, o documento influi 
na concretização do potencial para o progresso humano, explicitando que, para que isso se concretize, é necessário o acesso das pessoas à educação.

Em linhas gerais, a Declaração da Guatemala (UNESCO, 2001), estabelecida na Convenção da Organização dos Estados Americanos, através do Decreto $n^{\circ}$ 3.956, de 8 de outubro de 2001, promulga a "Convenção Interamericana para a eliminação de todas as formas de discriminação contra as pessoas portadoras de deficiência".

O marco das conquistas políticas em relação específica à comunidade Surda é recente no Brasil, tendo ocorrido há apenas uma década atrás, porém, após os anos 80, as pessoas com deficiências começaram a ganhar visibilidade nas políticas a partir do momento em que a Constituição Federal afirma no capítulo 3, Art. 205:

\footnotetext{
A educação, direito de todos e dever do Estado e da família, será promovida e incentivada com a colaboração da sociedade, visando ao pleno desenvolvimento da pessoa, seu preparo para o exercício da cidadania e sua qualificação para o trabalho (Brasil, 1988).
}

Merece ênfase a palavra "todos" descrita no artigo, a qual indica que, independentemente do contexto, seja de pessoas com deficiência ou de outra classe minoritária, todos os brasileiros possuem o direito à educação. $\mathrm{O}$ artigo incumbe essa responsabilidade ao Estado e à família.

Quanto à legislação brasileira, a inclusão escolar é considerada em alguns pontos vanguardista, de acordo com a Constituição Federal, Art.208, III que diz: "O atendimento educacional especializado aos portadores de deficiência deve ser promovido preferencialmente na rede regular de ensino" (BRASIL, 1988).

Garantindo-Ihes o direito à educação, de acordo com a Lei de Diretrizes e Bases (LDB) no 9394/96 - Art.58, que também estabelece: "Haverá, quando necessário, serviços de apoio especializado na escola regular, para atender às peculiaridades da clientela de educação especial" (BRASIL, 1996).

Em meio à transição para a educação bilíngue para Surdos, discussões foram realizadas entre educadores, pesquisadores e pessoas envolvidas com a comunidade Surda para implementar essa abordagem educacional da maneira mais adequada. Com isso, surge uma nova lei federal, Lei no 10.436 , de 24 de 
abril de 2002 (BRASIL, 2002), e o Decreto no 5.626, de 22 de dezembro de 2005 (BRASIL, 2005), possibilitando, assim, um direcionamento para o atendimento escolar do aluno Surdo e prevendo, também, a educação bilíngue (LACERDA et al., 2013).

A respeito da língua brasileira de sinais, a partir da Lei $n^{0}$ 10.436/2002 e do Decreto no 5.626/2005 que a regulamenta (BRASIL, 2002,), a Libras foi regulamentada como segunda língua brasileira e reconhecida como língua nacional de expressão e comunicação dos Surdos.

No ano de 2010, foi instituído o Decreto no 7.387 , que se refere ao Inventário Nacional da Diversidade Linguística, no Art. 1을

Fica instituído o Inventário Nacional da Diversidade Linguística, sob gestão do Ministério da Cultura, como instrumento de identificação, documentação, reconhecimento e valorização das línguas portadoras de referência à identidade, à ação e à memória dos diferentes grupos formadores da sociedade brasileira (BRASIL, 2010).

Conforme o Decreto citado (BRASIL, 2010), a Libras é uma língua que se enquadra nessas características e é própria à comunidade Surda brasileira. O Relatório sobre a Política Linguística de Educação Bilíngue - Língua Brasileira de Sinais e língua portuguesa (THOMA et al. 2014) traz diversos aspectos que permeiam a Libras e uma educação bilíngue aos alunos Surdos, entre eles especifica:

(...) o poder público, ao assegurar a educação bilíngue de Surdos, como alternativa legítima de educação, garante o acesso precoce das pessoas Surdas a uma língua de sinais plena, rica lexical e gramaticalmente. Isso se faz pelo ensino da Libras, pela pesquisa e pelo lugar efetivo que o uso da Libras adquire no quadro linguístico brasileiro (THOMA et al., 2014, p. 10).

Indica também que a Libras tem um peso linguístico, sendo necessário que ela seja trabalhada nas escolas bilíngues para Surdos para evitar trazer uma aquisição tardia de língua aos alunos e ser utilizada como língua de instrução (THOMA et al. 2014).

Comentando o Decreto lei $n=5.626$, Souza (2007) destaca os seguintes aspectos como direitos fundamentais da pessoa Surda: o decreto regulamenta a Lei $n^{0} 10.436$, que garante o direito do estudante Surdo a um ensino bilíngue nas escolas públicas e também privadas, desde a educação infantil, com o 
ensino da Libras em conjunto com a língua portuguesa em sua modalidade escrita como segunda língua. Regulamenta ainda que o currículo dessas escolas bilíngues necessariamente deve ser desenvolvido em Libras e em língua portuguesa, garantindo, assim, acessibilidade linguística ao estudante. Além disso, o decreto garante a obrigatoriedade da disciplina de Libras nas grades curriculares das graduações relacionadas à educação (licenciaturas, pedagogia e educação especial) e fonoaudiologia sendo que, nos demais cursos de graduação, a disciplina deve ser oferecida como matéria optativa.

$\mathrm{Na}$ esfera de escolarização do Surdo, existem políticas definidas em dois modelos: quanto ao ensino de alunos Surdos ser obrigatório em escolas com salas de aula comuns ou em relação ao ensino em escolas de educação bilíngue, pois existem documentos que sugerem um tipo de escola como o mais adequado e outros documentos que sugerem o outro. Encontramos essa dualidade entre o Decreto lei ํo 5.626 (BRASIL, 2005), que sugere as escolas bilíngues, e a Política Nacional de Educação Especial na perspectiva da Educação Inclusiva (BRASIL, 2008), voltada para as escolas com salas de aula comuns.

As escolas bilíngues são previstas no Decreto lei o 5.626 (2005) que dispõe dos processos educativos específicos das pessoas Surdas, direitos dos Surdos a uma educação bilíngue e formação dos profissionais da área (LODI, 2013). É definido pelo art. 22, parágrafo 1ํ, que, nessas escolas, a Libras será mantida como L1 e o português como L2 através da leitura e escrita (BRASIL 2005) Para que a educação siga dessa maneira, os professores devem ministrar suas aulas em Libras, ou contar com intérpretes e instrutores em sala para mediar esse processo.

O Decreto lei no 5.626 (BRASIL, 2005) garante a disponibilização da educação em escolas bilíngues municipais, dos anos iniciais ao final do Ensino Fundamental II, sendo necessário ao aluno Surdo procurar escolas com salas de aula comuns para concluir seus estudos no Ensino Médio.

A Política Nacional de Educação Especial na perspectiva da Educação Inclusiva (BRASIL, 2008) indica a educação bilíngue nas escolas comuns como uma forma de inclusão do aluno Surdo. A respeito disso, Lodi (2013) afirma que a PNEEI: 
(...) reduz educação bilíngue à presença de duas línguas no interior da escola sem propiciar que cada uma assuma seu lugar de pertinência para os grupos que as utilizam, mantendo a hegemonia do português nos processos educacionais (LODI, 2013).

Essa política tem como foco propor ações que visam a acabar com a exclusão escolar e, consequentemente, social para os alunos com deficiências no geral (LODI, 2013). Porém, assim como afirma a autora, os alunos Surdos não têm o desenvolvimento linguístico necessário para se apropriarem de conteúdos específicos dentro das escolas com salas de aula comuns porque $o$ contato que eles têm com os conhecimentos específicos é a partir de uma tradução feita pelos intérpretes. Além disso, as avaliações, a depender do professor, são, em geral, realizadas em português.

Hoje em dia, o aluno Surdo possui o direito de escolher e se matricular em escolas específicas de educação bilíngue para Surdos, ou escolas com salas de aula comuns que por lei têm o dever de recebê-los e não rejeitar suas matrículas, além de garantir-Ihes a inclusão através de intérpretes e outros recursos com a priorização da Libras.

No ano de 2015, é instituída a LBI - Lei Brasileira de Inclusão da Pessoa com Deficiência de oㅜ 13.146, com o foco em assegurar e também promover "o exercício dos direitos e das liberdades fundamentais por pessoa com deficiência, visando à sua inclusão social e cidadania" (BRASIL, 2015). Dentre as Disposições Gerais, o Art. $2^{\circ}$ revela qual a definição de pessoa com deficiência que o documento adota:

Considera-se pessoa com deficiência aquela que tem impedimento de longo prazo de natureza física, mental, intelectual ou sensorial, o qual, em interação com uma ou mais barreiras, pode obstruir sua participação plena e efetiva na sociedade em igualdade de condições com as demais pessoas (BRASIL, 2015).

Especificamente referente à surdez, a LBI (2015) traz, no Capítulo IV, "Do direito à educação", Art. 28, a indicação de que a educação de qualidade à pessoa com deficiência deve ser assegurada pelo Estado, família, comunidade escolar e sociedade, incumbindo o poder público de "(...) assegurar, criar, desenvolver, implementar, incentivar, acompanhar e avaliar (...)" (p. 6) o que indica o inciso IV, a saber, a "(...) oferta de educação bilíngue, em Libras como primeira língua e na modalidade escrita da língua portuguesa como segunda 
língua, em escolas e classes bilíngues e em escolas inclusivas (...)" (p. 7), permitindo que se mantenham os trabalhos de escolas e salas bilíngues, mas não especificando o grau de escolarização em que esse trabalho deve ser feito.

Na cidade de São Paulo, o Decreto Municipal no 57.379, instituído no dia 13 de outubro de 2016, estabeleceu, com base nas políticas vigentes citadas anteriormente, diversos aspectos de garantia efetiva da pessoa com deficiência à educação. Afirma que considera:

(...) a deficiência como um conceito em evolução, resultante da interação entre as pessoas com deficiência e as barreiras atitudinais e ambientais que impedem a sua plena e efetiva participação na sociedade em igualdade de oportunidades com as demais pessoas" (BRASIL, 2016 p. 1).

Destina o capítulo $\mathrm{V}$ a falar sobre a educação bilíngue ofertada em Escolas Municipais de Educação Bilíngue para Surdos - EMEBS, Unidades Polo para Surdos e ouvintes e também em escolas comuns em todos os seus níveis, garantindo instrutor de Libras e guias-intérpretes (para alunos Surdocegos) nas EMEBS e Unidades Polo, além dos intérpretes.

No município de São Paulo, o aluno Surdo está respaldado legalmente a usufruir de uma educação bilíngue, cabendo a ele escolher em qual contexto escolar prefere obter sua formação.

\subsubsection{De "Escolas Especiais" a "Escolas Bilíngues para Surdos"}

A EMEBS - Escola Municipal de Educação Bilíngue de Surdos - é aberta prioritariamente ao público de alunos Surdos, oferecendo ensino do primeiro ano da educação infantil ao último ano do Ensino Fundamental II, o que está previsto no artigo 22, capítulo VI "da garantia do direito à educação das pessoas Surdas ou com deficiência auditiva" no Decreto 5.626 (2005).

3 Art. 22. As instituições federais de ensino responsáveis pela educação básica devem garantir a inclusão de alunos Surdos ou com deficiência auditiva, por meio da organização de: I - escolas e classes de educação bilíngüe, abertas a alunos Surdos e ouvintes, com professores bilíngües, na educação infantil e nos anos iniciais do ensino fundamental; II - escolas bilíngües 
Especificamente, os alunos Surdos do município de São Paulo têm as opções de escolha entre dois contextos educacionais: nas EMEBS destinadas prioritariamente aos alunos Surdos ou em escolas comuns da rede regular de ensino em que esses alunos se encontrariam no contexto de inclusão, sendo que em qualquer um desses espaços os alunos possuem o direito a uma educação bilíngue com todo o contexto que ela necessita para ser aplicada (LACERDA et al. 2013).

Além das escolas bilíngues de Surdos e escolas comuns da rede regular de ensino, no município de São Paulo, pode-se encontrar também as escolas denominadas Unidades Polo de Educação Bilíngue, citadas no Decreto Municipal no 57.379, do ano de 2016. Nessas escolas, o trabalho transita entre escola bilíngue e escola comum, sendo os primeiros anos das séries iniciais com os alunos Surdos separados dos ouvintes em salas bilíngues e passando por momentos de interação no intervalo e demais atividades escolares. Assim, ao chegar ao Ensino Fundamental II, todos os alunos, sejam eles Surdos ou ouvintes, são colocados juntos na mesma sala, com o auxílio do intérprete durante todas as aulas. Nessa escola, alunos ouvintes podem também ter aulas de Libras e os alunos Surdos passam por aulas de reforço de português enquanto os alunos ouvintes estão na aula de inglês.

No município de São Paulo, encontram-se, ao todo, seis escolas de educação bilíngue para Surdos e duas escolas Polo.

Conforme as políticas públicas vigentes, especificamente a PNEEI (2008), o atendimento dos alunos com deficiência deve ser realizado preferencialmente nas escolas comuns da rede regular de ensino, mas até o ano de 2011, existiam, no município de São Paulo, as EMEE - Escolas Municipais de Educação Especial. Em consequência dessas políticas, essas escolas foram abertas ao público geral, perdendo a especificidade de atender somente ao público de alunos com deficiência. Contudo, as EMEE que atendiam especificamente ao público Surdo se mantiveram, mas houve uma mudança de nome, de EMEE para EMEBS, provando a necessidade de se

ou escolas comuns da rede regular de ensino, abertas a alunos Surdos e ouvintes, para os anos finais do ensino fundamental, ensino médio ou educação profissional, com docentes das diferentes áreas do conhecimento, cientes da singularidade lingüística dos alunos Surdos, bem como com a presença de tradutores e intérpretes de Libras - Língua portuguesa. Decreto 5.626 (BRASIL, 2005). 
continuar com escolas específicas para Surdos em defesa do respeito à Libras como língua de instrução e à cultura da comunidade Surda, sendo esses indivíduos amparados legalmente através do Decreto ํㅜ‥626 do ano de 2005 e, recentemente, pelo Decreto Municipal oㅜ 57.379 do ano de 2016 .

De acordo com Lacerda et al. (2013), os prós e os contras das diferentes abordagens em que o aluno Surdo pode se inserir ampliam-se para condições concretas e necessárias dessas mesmas propostas nas políticas governamentais, não se restringindo a aspectos como o direito linguístico, o contato com usuários da língua de sinais, ou mesmo a abordagem metodológica e atuação de profissionais com formação bilíngue.

Alguns alunos que têm deficiências variadas associadas à surdez também possuem o direito de realizar matrícula nas escolas bilíngues para Surdos (EMEBS), necessitando, assim, um trabalho de inclusão também nessas escolas com adaptações estruturais e metodológicas necessárias para recebê-los.

De acordo com o capítulo 3 , artigo 7 do Decreto 4.626 , todo o corpo docente deve ser capacitado para ministrar suas aulas em Libras, inclusive a equipe de coordenação, pois a Libras é a comunicação prioritária nesse ambiente.

Como forma de facilitar a comunicação entre professores e funcionários ouvintes e alunos Surdos, a escola possui os instrutores, preferencialmente Surdos, que fazem essa mediação, tanto em aulas quanto em atividades extraclasse e ministrando também aulas de Libras. Eles desempenham o papel de modelo linguístico, de identidade Surda e de adulto Surdo aos estudantes, construindo uma didática bilíngue nas escolas, já que a formação de profissionais bilíngues ainda não é vasta (LACERDA et al. 2013).

Algumas práticas podem ser observadas em comum nas escolas bilíngues de educação de Surdos, como, por exemplo, o número reduzido de alunos por sala para facilitar a comunicação; carteiras dispostas em meio círculo para facilitar a visualização da fala dos outros alunos; utilização da lousa para introduzir o português; explicação em Libras de todo o conteúdo

\footnotetext{
4 "III - professor ouvinte bilíngue: Libras - Língua portuguesa, com pós-graduação ou formação superior e com certificado obtido por meio de exame de proficiência em Libras, promovido pelo Ministério da Educação" Decreto 5.626 (BRASIL, 2005).
} 
escrito e avaliações feitas em português e Libras para verificar o nível de aprendizado bilíngue dos alunos.

\subsection{Cultura Surda e identidade linguística}

Quero entender o que dizem. Estou enjoada de ser prisioneira desse silêncio que eles não procuram romper. Esforço-me o tempo todo, eles não muito. Os ouvintes não se esforçam. Queria que se esforçassem (LABORIT, 1994, p. 39).

A surdez pode ser concebida por diferentes concepções ideológicas. Hoje, as mais recorrentes são: clínico terapêutica, referente ao diagnóstico como anormalidade ou defeito, a cirurgia de implante coclear como resolução do "problema" para enquadrá-lo como "normal" em uma sociedade ouvinte, sendo esta uma concepção patológica da surdez, enfatizando a deficiência do indivíduo e suas limitações; de ordem linguística, a partir de processos diferentes de aquisição e desenvolvimento da linguagem oral e também de sinais; de ordem educacional, com abordagens específicas para o Surdo em seu desenvolvimento escolar e direcionando seu aprendizado e atividades elaboradas a partir de suas condições; de ordem terapêutica, através de acompanhamento, principalmente, no campo da fonoaudiologia; de ordem social, com as interações com os ouvintes, sejam elas como forem, através da língua de sinais, gestos, ou também a fala; de ordem trabalhista, com a inserção no mercado, suas dificuldades de arranjar emprego e suas lutas pelo aumento da "cota" de vagas para deficientes e, por fim, de ordem política, com a luta pelos direitos dos Surdos e reconhecimento da língua de sinais (SANTANA, 2007).

Segundo Skliar (1998, p.11), a surdez é considerada desde uma diferença que necessita ser politicamente reconhecida até uma identidade múltipla e multifacetada do sujeito que a possui. Para uns, é enquadrada no âmbito das deficiências e, para outros, no de uma diferença linguística. 
Para Inácio (2004), a surdez não é algo simples de ser determinado, pois existem diferentes graus de perdas auditivas. Além desse fato, 0 relacionamento social e a visão de mundo do sujeito Surdo são tão diferenciados que devem ser levados em consideração. Porém, a definição de surdez limita-se somente a um modelo médico indicando o grau de perda auditiva do sujeito?

Gesueli (2006), Santana (2007) e Santana e Bergamo (2005) indicam que a surdez não é homogênea, não existe uma identidade exclusiva e única. Afinal, são pessoas assim como quaisquer outras, construídas por papéis sociais diferentes, fazendo parte de classes populares, ricos, mulheres, homens, homossexuais ou heterossexuais, negros, brancos, habitantes de zona rural e qualquer outro grupo social etc., e, além disso, ainda se diferenciam pela língua que constrói a subjetividade de cada um, refletindo-se como um mosaico.

No tema da surdez, existem várias dicotomias que refletem os diferentes posicionamentos que os Surdos devem tomar perante à perda auditiva. Relacionando com os conflitos e pressões sociais que os Surdos enfrentam na sociedade ouvinte, Santana (2007) pontua algumas dessas dicotomias: "deficiente/diferente; cultura Surda/cultura ouvinte; normalidade/anormalidade; linguagem oral/ língua de sinais".

Não é possível limitar os Surdos, enquadrando-os em um único padrão cultural. Dentro da perspectiva do "não ouvir", existem Surdos que se consideram pessoas com deficiência auditiva, desejam utilizar aparelhos auditivos ou submeter-se a cirurgia de implante $\operatorname{coclear}^{5}$ e alegam não necessitar da Libras por utilizarem a língua oral. Por outro lado, existem Surdos implantados ou que utilizam aparelho e são adeptos à Libras, Surdos que se recusam a submeter-se a aparelhos ou implantes, justificando que a Libras já basta, entre outros. A intenção não é novamente enquadrar os Surdos em outras categorias, mas mostrar que, como seres humanos, são únicos, singulares e não passíveis de uma padronização dentro das categorias de

\footnotetext{
5 Implante Coclear: Conhecido como "ouvido biônico", é um aparelho tecnológico implantado cirurgicamente no indivíduo que não se adaptou a aparelhos auditivos. O implante funciona estimulando diretamente o nervo auditivo por meio de pequenos eletrodos que são colocados dentro da cóclea, levando estes sinais para o cérebro (fonte: http://www.implantecoclear.org.br/textos.asp?id=5).
} 
Surdos ou deficientes auditivos, devendo-se respeitar a cada um em sua forma de enxergar a si mesmos.

Cabe ressaltar que estou defendendo que cada indivíduo deve ser respeitado em relação a como deseja se desenvolver linguisticamente, enfatizando que acredito que a escolha deve ser feita quando este indivíduo for maduro o suficiente para fazer escolhas e que a educação escolar dos Surdos deve levar em conta suas condições linguísticas. Com essa defesa, posicionome contra todas as técnicas forçosas de implementação de um padrão de normatizar o indivíduo Surdo tentando torná-lo ouvinte, valorizando-o somente quando conquista a fala oral, alegando que, como são minoria, devem se submeter à língua da maioria, pois seria utópico pensar em uma sociedade (ouvinte e Surda) que utilize plenamente a língua de sinais em todos os ambientes. O Surdo que deseja submeter-se à oralização e implantação de aparelhos auditivos deve, de igual modo, ser respeitado, mas quando esse desejo parte do próprio indivíduo maduro o suficiente para essa decisão e não quando é imposto por sua família.

É compreensível que em uma família em que não há indivíduos Surdos, não tem o conhecimento de como tratar do primeiro Surdo que aparece. Muitas vezes, tomam decisões pautadas no tipo de orientação que recebem, que em geral, são orientações vindas de médicos ou profissionais da saúde, muitas vezes com uma visão clínico-terapêutica da Surdez. A família escolhe uma cirurgia de implante coclear ou submeter seus filhos à oralização sem ao menos conhecer um Surdo falante da língua de sinais e suas vivências. Infelizmente, essa é outra área em que a valorização médica se sobrepõe à educacional, que o ponto de vista clínico-terapêutico se sobrepõe ao sócioantropológico, e em consequência, a família toma uma decisão por acreditar que é a melhor ao seu filho, sem antes conhecer "os dois lados da moeda".

Antes de se submeterem a esses métodos, deveria ser esclarecido às pessoas Surdas ou com deficiência auditiva que esses avanços médicotecnológicos não eliminam a condição de surdez do indivíduo, e, sim, torna-se possível que eles passem, diariamente, por momentos de ouvintes. Por exemplo, uma pessoa que usa aparelho auditivo ou implante coclear precisa remover o aparelho (no caso do implante, remover somente a parte externa) para algumas atividades como tomar banho, ir ao cabeleireiro, nadar e também 
dormir. Tais aparelhos não eliminam a condição da surdez e não torna um indivíduo ouvinte, pois a pessoa tem, no mesmo dia, momentos em que ouve e momentos em que não ouve. Para um ouvinte, a falta de som é uma privação, enquanto para os Surdos, é uma condição.

$\mathrm{Na}$ perspectiva do Surdo que utiliza a língua de sinais, esta pode ser adquirida conforme sua inserção na cultura Surda e os estímulos que recebe, se ele tiver acesso ao aprendizado e domínio dessa língua, poderá ter como segunda língua o português (INÁCIO, 2004). O autor ainda afirma que, para o ouvinte, ocorre o inverso desse processo, mas ele só aprende a língua de sinais desde que mostre interesse, podendo ser um intérprete em algumas situações, sendo uma ponte entre o mundo ouvinte e o mundo Surdo, sem qualquer perda cultural para ambos os sujeitos e, muito pelo contrário, esse ouvinte pode oferecer uma rica visão de um grupo social que tem muito para nos ensinar.

A partir do momento em que a língua de sinais é reconhecida como uma língua e não desmerecida como uma simples gesticulação, a repercussão passa a ser também social (SANTANA, 2007). Ao considerar um sujeito "anormal" como alguém que não possui uma língua e tudo o que ela representa, com a língua de sinais esse padrão se altera, pois, a língua de sinais legitima a pessoa Surda, transformando a "anormalidade" em diferença, trazendo consigo uma delimitação de esferas sociais: "a identidade Surda, a cultura Surda e a comunidade Surda" (SANTANA, 2007, p. 33).

A língua de sinais está relacionada à cultura Surda que, por sua vez, reflete a identidade Surda de uma pessoa que convive, na maior parte dos casos, com a comunidade ouvinte e Surda. Essa pessoa é constantemente comparada às ouvintes, como se sua própria identidade Surda fosse inferior ou como se faltassem elementos em relação aos ouvintes (GESUELI, 2006). Essa comparação está no padrão "ideal" que a cultura ouvinte acredita ser "normal", e quem se encontra fora desse padrão deve ser corrigido:

Seria, portanto, nessa relação, no tempo e no espaço, com diferentes outros que o sujeito se construiria. É, com isso, nas práticas discursivas que o sujeito emerge e é revelado. Ou seja, é principalmente no uso da linguagem - e não qualquer materialidade linguística específica - que as pessoas constroem e projetam suas identidades (Santana e Bergamo, 2005, p. 568). 
A surdez, quando observada a partir da Libras, dá o significado para o Surdo por sua forma diferente de se comunicar não de forma oral, mas motora (INÁCIO, 2004). Nem sempre o aprendizado da língua oral é bem-sucedido e, no aspecto da deficiência, não deveria ser nem obrigatório (LACERDA, 2007).

Sendo a Libras uma língua ainda pouco conhecida pela sociedade, as possibilidades interativas dos Surdos continuam bastante restritas, atrapalhando sua aprendizagem e seu desenvolvimento social (SÁ, 2002), mas a surdez não permite que o indivíduo tenha menos possibilidades, e sim que tenha possibilidades diferentes.

De acordo com Vigotski (1999), o aspecto linguístico é fundamental para a compreensão do desenvolvimento do sujeito enquanto ser social, mas para a utilização de uma outra língua, como o português, é necessário garantir que o Surdo tenha condições de se apropriar de sua língua materna, a Libras.

Para Capovilla (2000), a linguagem possui uma importante função interpessoal e intrapessoal. A função interpessoal está relacionada à comunicação social e a função intrapessoal relaciona-se ao fato de que a linguagem permite o pensamento, formação e reconhecimento de conceitos, possibilitando uma aprendizagem consciente (CAPOVILLA, 2000).

Ao refletir sobre a aquisição de linguagem, Inácio (2004) destaca duas formas: a língua natural, adquirida desde o nascimento, e outra como sendo uma segunda língua. No caso do Surdo brasileiro, há uma discussão acerca da necessidade de que Libras seja encarada como uma primeira língua (L1) e a língua portuguesa como uma segunda língua (L2) para que possa se expressar por meio da leitura e escrita (forma da comunicação oral que cabe aos Surdos). Assim, o Surdo poderia possuir uma "comunicação plena".

De acordo com Gesueli (2006, p. 279), pode-se traduzir a surdez abrangendo todos os tipos de significações: "intelectual, linguístico, ético, estético, artístico, cognitivo, cultural, e as demais". Com isso, Skliar (1997) defende que é necessário um modelo baseado na língua de sinais como principal para a identificação sociocultural, baseado nas interações habituais dos Surdos. O pesquisador defende também que o modelo pedagógico não tenha como foco corrigir uma deficiência, mas continuar com um mecanismo de 
compensação que, de acordo com o autor, os próprios Surdos já utilizam historicamente

Quanto à identidade Surda, alguns autores mencionam que a língua de sinais é algo que define a pessoa Surda com essa identidade em seu contato com outro Surdo. Santana e Bergamo (2005, p. 567) identificam que: "em contato com outro Surdo que também use a língua de sinais surgem novas possibilidades interativas, de compreensão, de diálogo, de aprendizagem, que não são possíveis apenas por meio da linguagem oral".

Ao considerarmos a língua de sinais algo que define a identidade Surda, é enfatizado seu "caráter instrumental", com isso, a natureza da língua e também a sua representação social tornam-se condicionadas às interações sociais com as quais está envolvida (SANTANA \& BERGAMO, 2005).

Pode-se dizer que a identidade Surda se expressa da seguinte maneira:

\begin{abstract}
A constituição da identidade pelo Surdo, portanto, não é relacionada à língua de sinais necessariamente, mas sim à aquisição de uma língua possibilitando-os imergir no mundo como "falante", com as devidas implicações nas suas relações sociais, ou seja, não limita que os Surdos constituam sua identidade através da língua de sinais apenas pois, a identidade não pode ser vista como inerente às pessoas, e sim como "resultado de práticas discursivas e sociais em circunstâncias sócio-históricas particulares." (SANTANA \& BERGAMO, 2005, p. 570).
\end{abstract}

Outro ponto importante destacado por Santana e Bergamo (2005) é que a maneira como a surdez é vista na sociedade também é um fator que influencia a construção da identidade, sendo que o sujeito não pode ser visto dentro de um grupo isolado, mas como alguém que afeta e é afetado pelos discursos e práticas produzidos.

A diferença deve ser pensada como marca identitária, sem fixar outras marcas pejorativas e sem se questionar se os Surdos são ou não diferentes dos ouvintes ou de outros grupos culturais, étnicos ou religiosos, assim, devese pensar nessa diferença para o fortalecimento da comunidade Surda (LOPES, 2011).

O ponto de vista de uma autora Surda (PERLIN, 2003) traz a identidade Surda em uma perspectiva do ser e estar Surdo, considerando um "estar na experiência Surda" como parte ativa que se conduz nas dinâmicas de poder que constituem um povo Surdo, uma comunidade Surda: 
Entre a proposta do "ouvinte" e a proposta do Surdo surge esta diferença de ser, essa diferença que é perpassada pela experiência única e intransferível de cada sujeito. Experiências vividas em cada tempo, em cada realidade, em cada situação, nunca repetidas por outros, nunca iguais (PERLIN, 2003, p. 90).

Essa comunidade Surda é marcada pela forma de comunicação que vem com a surdez como um elemento fortalecedor (LOPES, 2011).

Na perspectiva bilíngue, a pessoa Surda é vista também como bicultural, ou também, multicultural:

\begin{abstract}
O biculturalismo designa o conjunto de referências à história dos Surdos, o conjunto de significações simbólicas veiculadas pelo uso de uma língua comum, o conjunto de estratégias sociais e de códigos sociais utilizados de maneira comum pelos Surdos para viverem numa sociedade feita por e para os ouvintes. É, portanto, uma cultura de adaptação à diferença e produtora de elo social (SANTANA E BERGAMO, 2005).
\end{abstract}

De certa forma, os Surdos estão em uma sociedade pensada primeiramente no ouvinte. Para se adequarem à rotina diária, os ambientes que frequentam necessitariam de adequações principalmente relacionadas à comunicação. A cultura Surda, assim como afirmado no fragmento acima, é um conjunto de marcadores culturais comuns às pessoas Surdas, adaptadas nessa sociedade ouvinte. Perlin (2003) afirma que a cultura Surda abrange língua de sinais, intérprete e determinadas tecnologias.

Por mais que a cultura esteja associada a práticas e comportamentos, costumes, hábitos, tradições, envolve também regras, metodologias e instruções para direcionar o comportamento daqueles que a compartilham (SANTANA \& BERGAMO, 2005).

De acordo com Lopes:

Cultura, significado e comunicação estão intimamente intrincados que não há como saber quando um termina para começar o outro. Assim, entender os significados que damos à palavra surdez ou à expressão ser Surdo vai depender de um conjunto de relações entre aqueles três elementos (LOPES, 2011, p. 16).

O termo "cultura" tem como origem o termo "cultivo", no sentido de uma produção gerada por distintas práticas sociais, e o termo "agrícola", com 0 
sentido de ação, atividade, em que a própria natureza tem uma condição de possibilidade para que uma cultura se estabeleça (LOPES, 2011). Quando se fala sobre cultura Surda, Lopes (2011) aponta que a diferença ao se refletir sobre o Surdo está na cultura e não exclui o fato de eles não ouvirem, já que este também não é um elemento definidor, marcando, assim, uma diferença entre "surdez e falta de audição", mas que: "a noção da diferença cultural coloca-se dentro da necessidade de estabelecer comparações entre sujeitos pertencentes a grupos sociais distintos (LOPES, 2011, p. 22)".

Tanto o sentido clínico patológico quanto o sentido antropológico que se dá à surdez são invenções culturais. Portanto, deve-se demarcar qual o entendimento e embasamento teórico a partir dos quais serão construídos sentidos acerca do que é "ser Surdo" (LOPES, 2011). A surdez não pode ser marcada pela falta, e sim pelo que ela marca como diferente (LOPES, 2011).

\subsection{Língua brasileira de sinais - Libras}

A Libras não teve sua origem na língua portuguesa, uma língua constituída na oralidade, mas na Língua de Sinais Francesa, outra língua de modalidade viso-espacial, porém, não se nega que a Libras foi influenciada em sua fundamentação lexical pela língua portuguesa. No entanto, esta influência se dá somente no que se refere às adaptações necessárias por serem línguas em contato (ALBRES, 2005).

No Brasil, além da Libras, há registros de uma outra língua de sinais utilizada pelos índios Urubu-Kaapor na Floresta Amazônica (FELIPE, 1997). Com uma proporção de 1 Surdo para cada 75 ouvintes na tribo, todos têm o conhecimento da língua de sinais, sejam eles Surdos ou ouvintes.

A língua brasileira de sinais, assim como as demais línguas, tem uma gramática própria, diferente da língua oral dominante, no caso do Brasil, a língua portuguesa. Configura-se diferentemente de uma língua oral, porém, é caracterizada como uma língua e não como uma linguagem, gesticulação ou 
mímica. As línguas orais se utilizam da boca e voz para verbalizar os sons, proferindo palavra a palavra, já as línguas de sinais são caracterizadas pela ausência do som, com a comunicação sendo exprimida através das mãos e corpo desempenhando o mesmo papel da boca e voz, porém as "palavras" são denominadas sinais (ALMEIDA; ALMEIDA, 2008).

Por não exigir a utilização da voz, as línguas de sinais se constituem com a recepção de sinais por meio da visão, e a execução dos sinais através do corpo, mãos e expressões faciais, caracterizando-a como uma língua visoespacial. Já as línguas orais são exprimidas através da fala e captadas pelo aparelho auditivo, caracterizando-as, assim, como orais-auditivas (LEITE, 2008).

Como as línguas de sinais se configuram espacialmente, não são necessárias entre as frases, palavras de ligação e caracterização como artigos, conjunções e alguns verbos de ligação, já que o próprio espaço explicita a ação através do movimento e configuração dos próprios sinais. Assim, seguem contrárias à linearidade das línguas orais nas quais, para se descrever uma cena ou uma situação, é necessário especificar em palavras para indicar o ocorrido. Assim, nas línguas orais, os termos seguem-se sequencialmente e, nas línguas de sinais, simultaneamente (LEITE, 2008). Por exemplo: ao se referir à distância de uma pessoa ou objeto, utilizamos na língua oral os pronomes "este, esse ou aquele" e, na língua de sinais, essa distância é representada na execução manual dos sinais descritivos próxima ao corpo, na frente ou com a mão distante.

Stokoe (1960) teve um trabalho pioneiro no estudo linguístico da língua americana de sinais- ASL, que hoje é considerada a língua mais desenvolvida. Inicialmente, Stokoe propôs que a língua de sinais era formada por três componentes: configuração de mãos (CM), localização (L) e movimento (M) (LEITE, 2008). No Brasil, a Libras define-se a partir destes parâmetros, somando a orientação da palma da mão durante a execução do sinal e as expressões não manuais associadas ao significado do sinal. 


\subsubsection{Parâmetros da Libras}

A Libras se estrutura a partir de cinco parâmetros principais: configuração de mãos, ponto de articulação, movimento, orientação de mãos e expressões não manuais (CHOI, 2011).

A configuração de mãos - CM - indica qual posição a mão deve assumir durante um sinal. Como um guia para executar a $\mathrm{CM}$, existe uma tabela base em que as possíveis CM's estão ali apresentadas (Figura 02):

Figura 02: Configuração de mãos de acordo com o Instituto Nacional de Educação de Surdos INES.

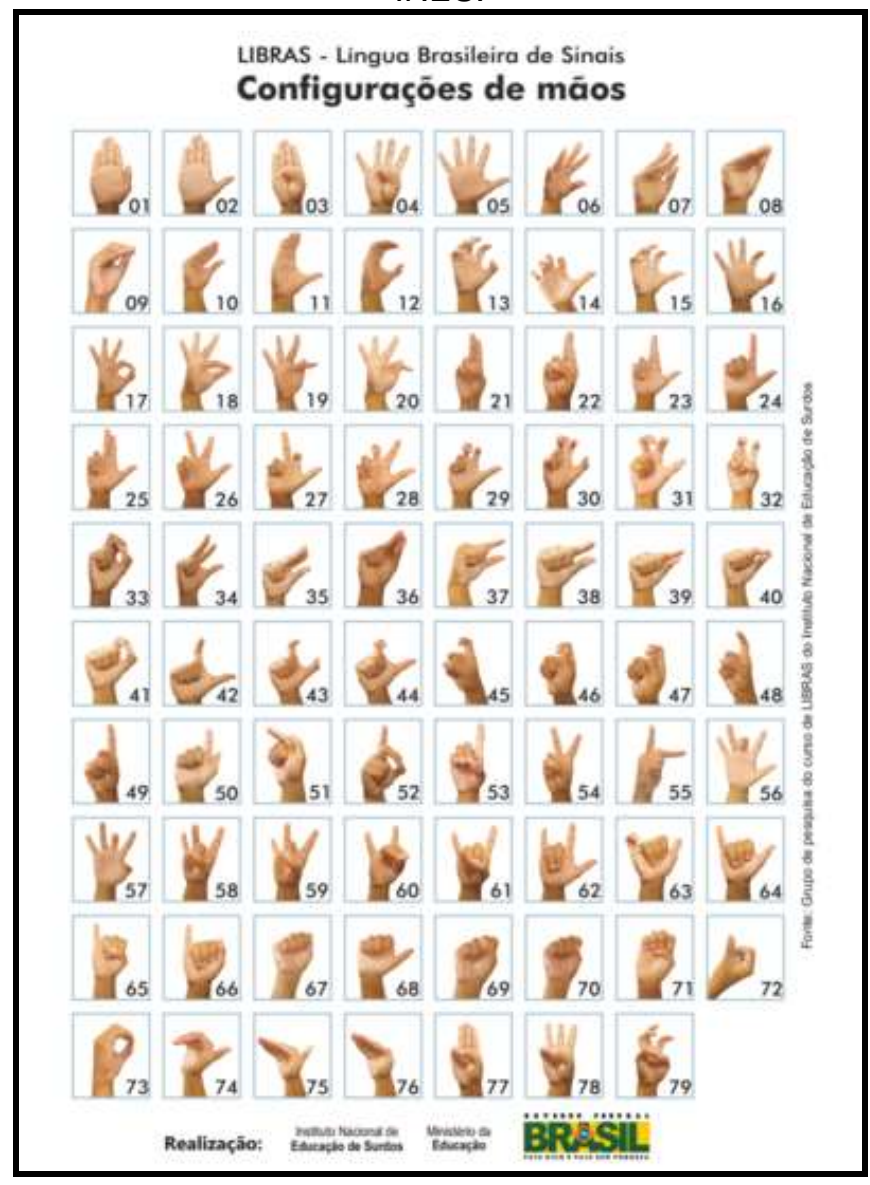

Fonte: http://ines.gov.br/biblioteca-ines

Essa tabela está suscetível a constante crescimento, pois, de acordo com o próprio desenvolvimento da Libras, novas possíveis configurações podem surgir conforme se criam novos sinais. Por exemplo, a Universidade Federal de Santa Catarina desenvolveu, em seu site, uma plataforma de 
buscas de sinais da Libras por palavras correspondentes ao português, palavras correspondentes em inglês ou também por configuração de mãos. No site, foram listadas, ao total, 134 configurações de mãos possíveis, separadas de acordo com os dedos que cada configuração usa, como mostra a figura 03 a seguir:

Figura 03: Configurações de mãos separadas de acordo com os dedos que as compõem.

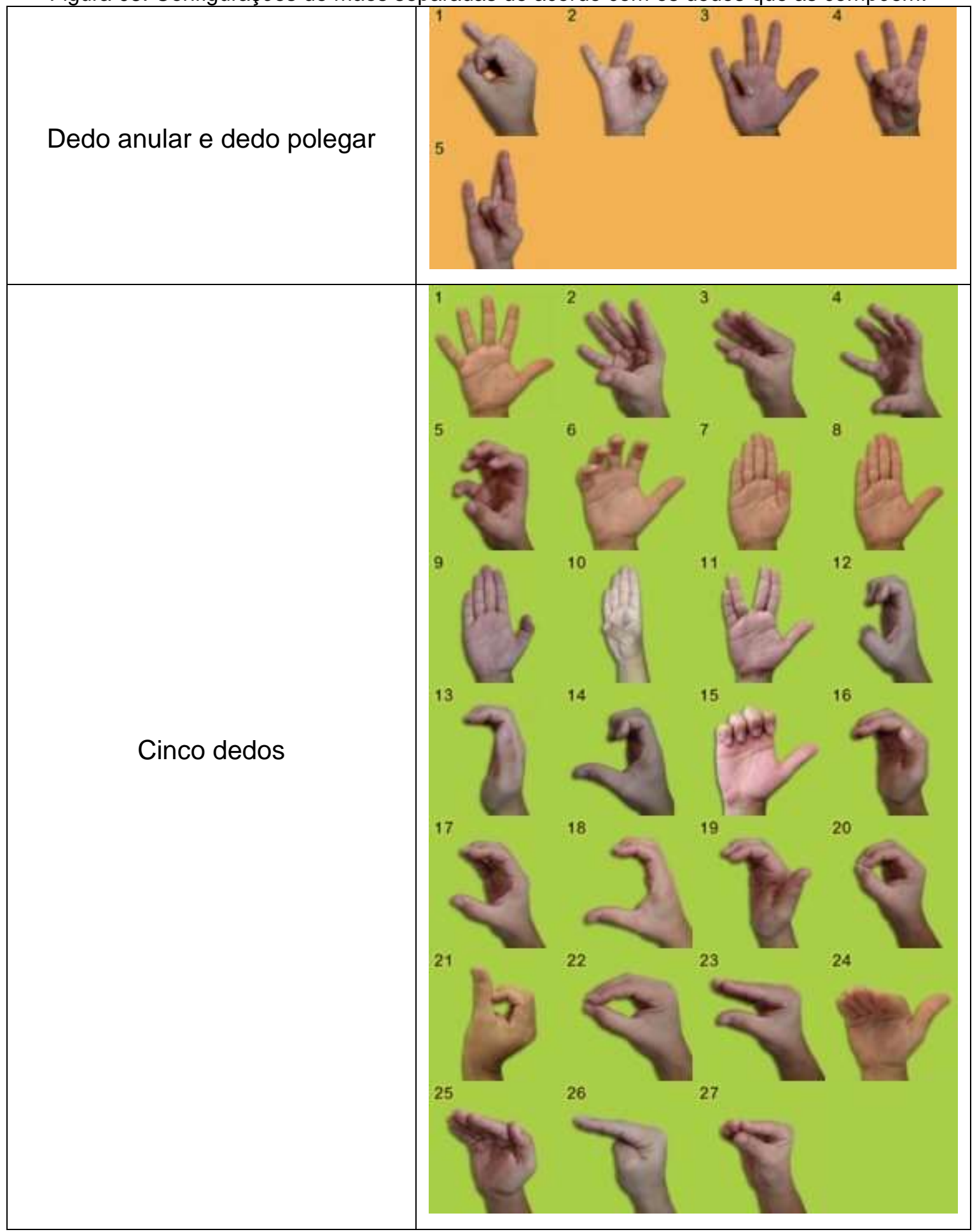




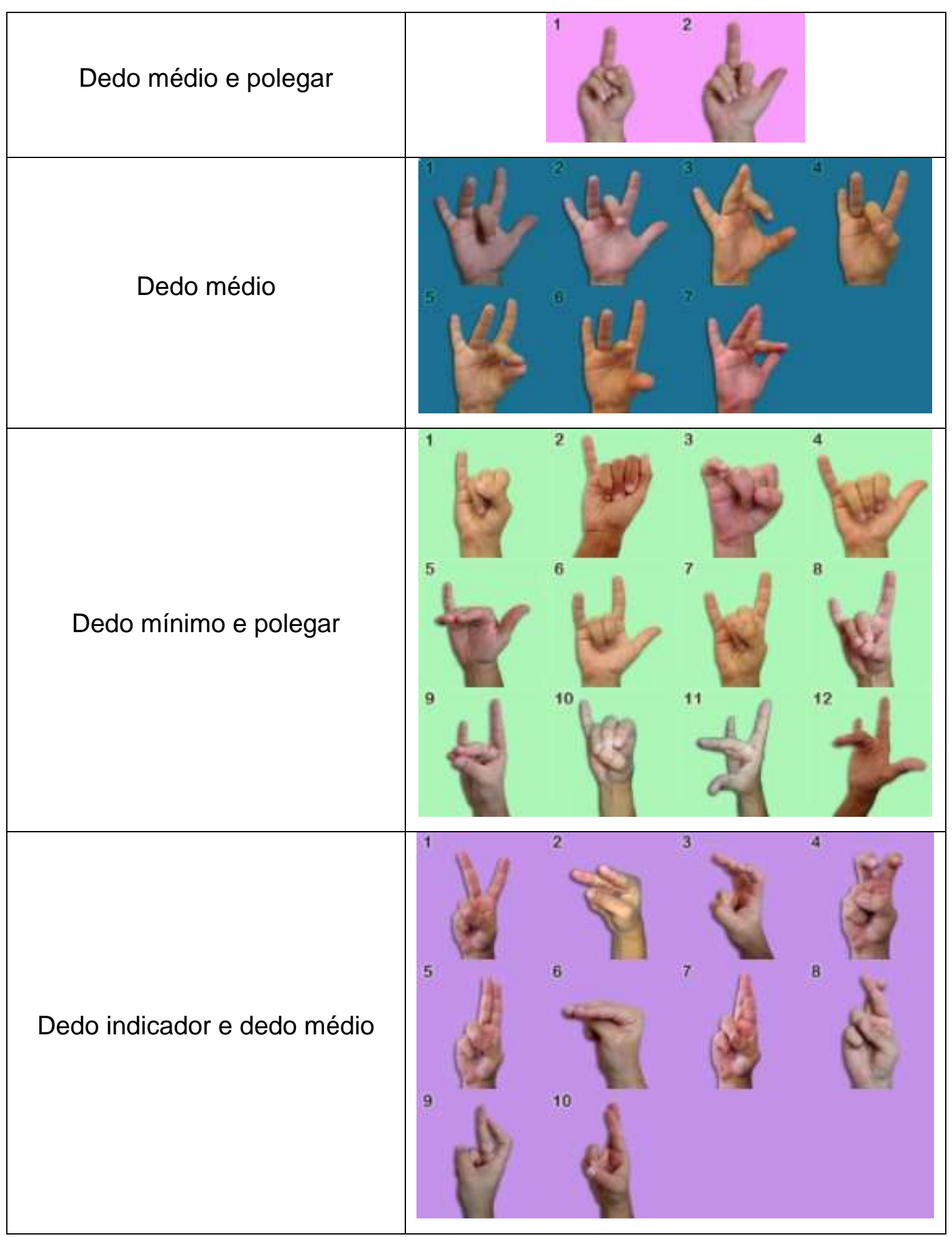




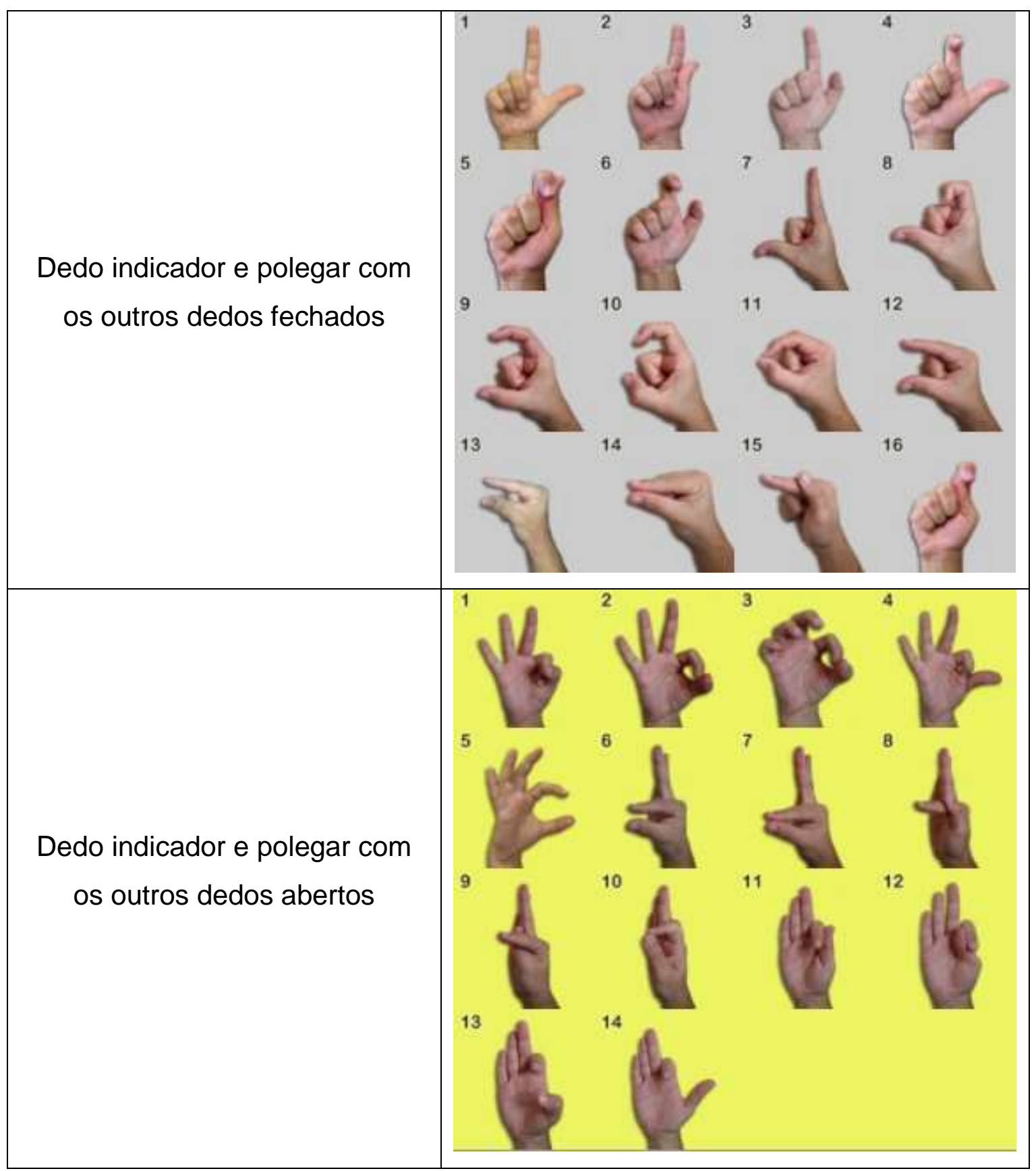




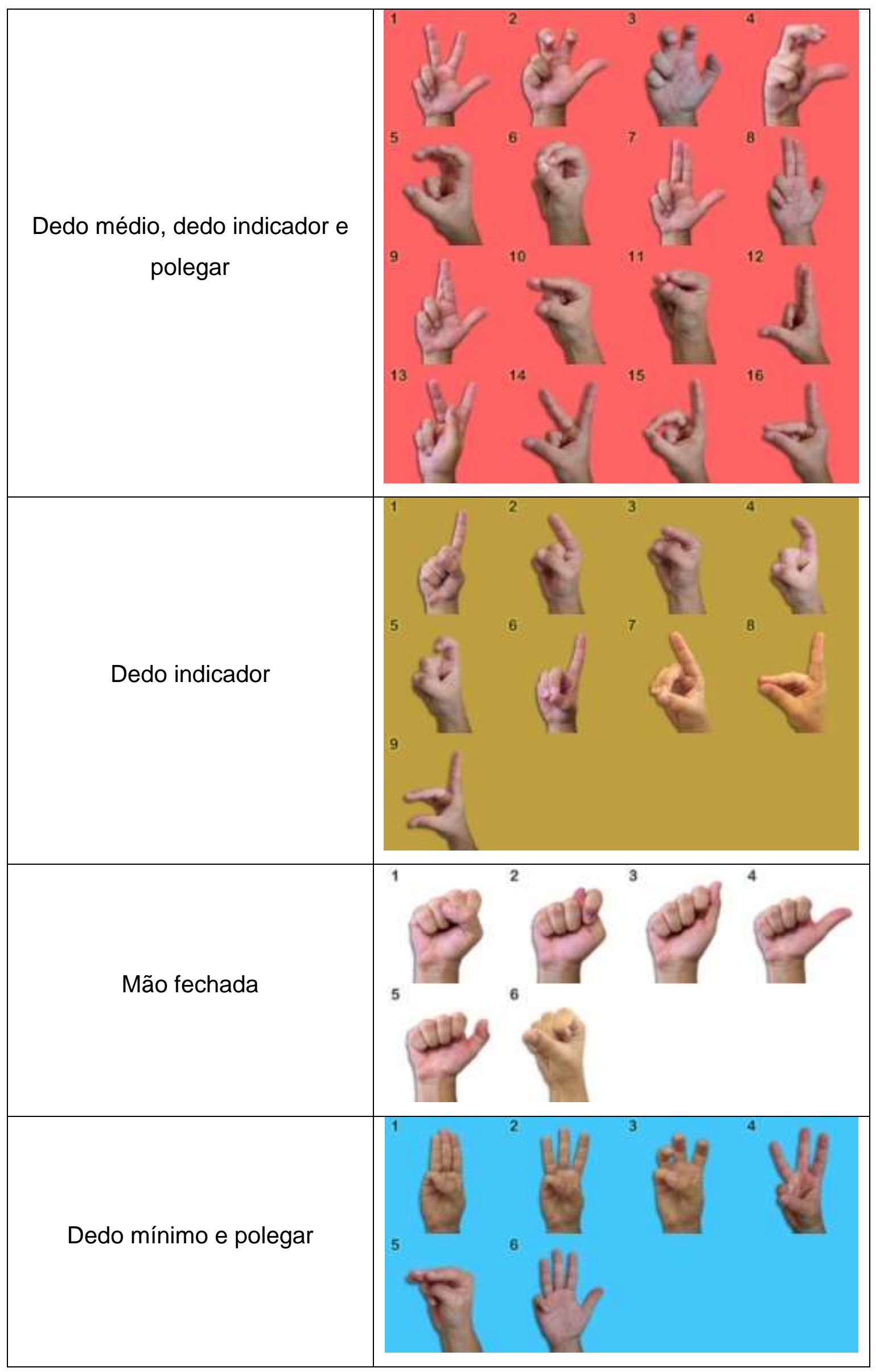




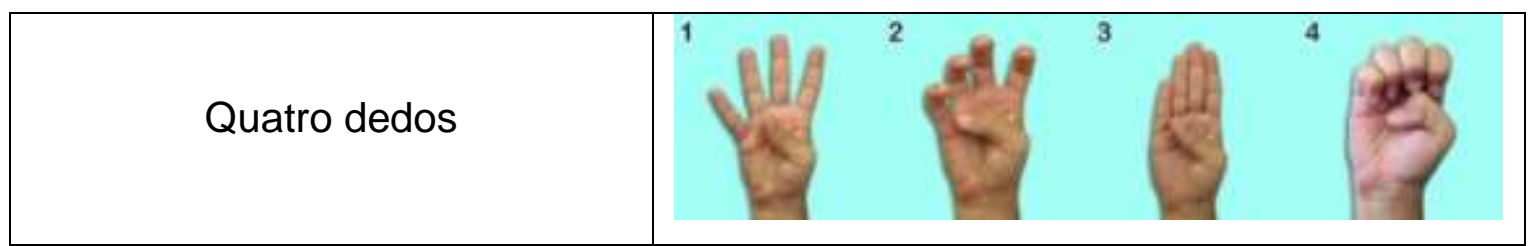

Fonte: http://idsinais.libras.ufsc.br/

Dois sinais podem apresentar a mesma configuração de mãos, porém, seu significado difere de acordo com os outros parâmetros, assim como pode ser observado na Figura 04.

Figura 04: Representação do sinal APRENDER6 "Mão direita em "S" vertical, palma para a esquerda, tocando a testa. Abrir e fechar ligeiramente a mão duas vezes" (CAPOVILLA \& RAPHAEL, 2006, p.215) e LARANJA "Mão direita em "S" vertical, palma para a esquerda, diante da boca. Abrir e fechar ligeiramente a mão" (CAPOVILLA \& RAPHAEL, 2006, p.799), ambos com a mesma configuração de mãos, porém executados em diferentes partes do corpo.
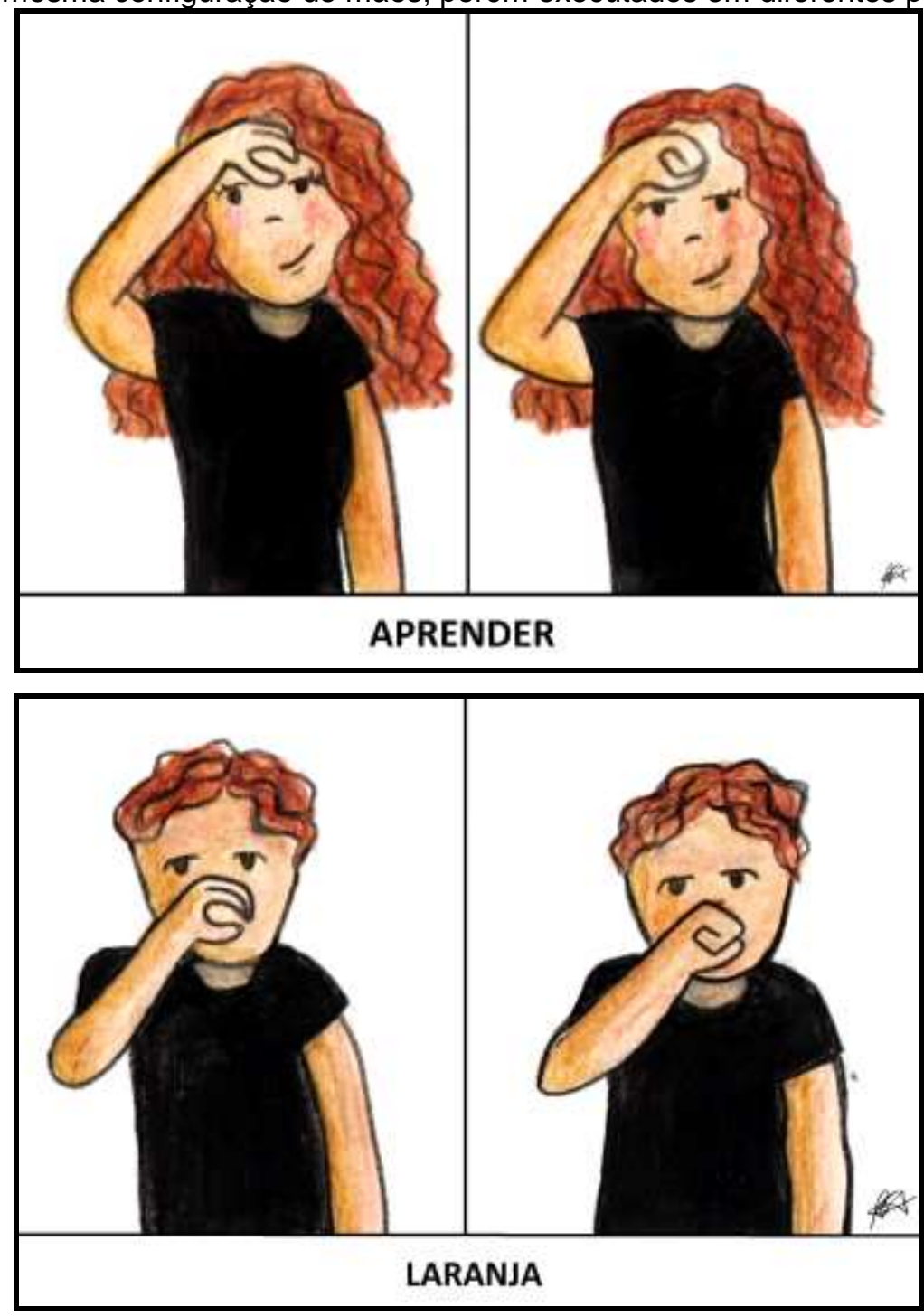

Fonte: Imagem elaborada pela pesquisadora Beatriz Crittelli

${ }^{6}$ Toda palavra escrita que representa um sinal de Libras é escrita em caixa alta. 
O Ponto de articulação - PA - representa a região do corpo em que o sinal é realizado, ou seja, em qual ponto o sinal será articulado, na testa, nariz, orelha, boca, frente ao braço, tronco etc (CHOI, 2011). (Figura 05).

Figura 05: Representação do sinal TRABALHAR "Mãos em L horizontal, palmas para baixo, na altura da cintura. Movê-las, alternadamente, para frente e para trás duas vezes. " (CAPOVILLA \& RAPHAEL, 2006, p.1264) com o ponto de articulação no espaço neutro frente ao corpo e sinal ESQUECER "Mão direita horizontal aberta, palma para dentro, pontas dos dedos unidas, tocando o lado esquerdo da testa. Mover a mão para o lado direito da testa. " (CAPOVILLA \&

RAPHAEL, 2006, p.618) com o ponto de articulação frente a testa.
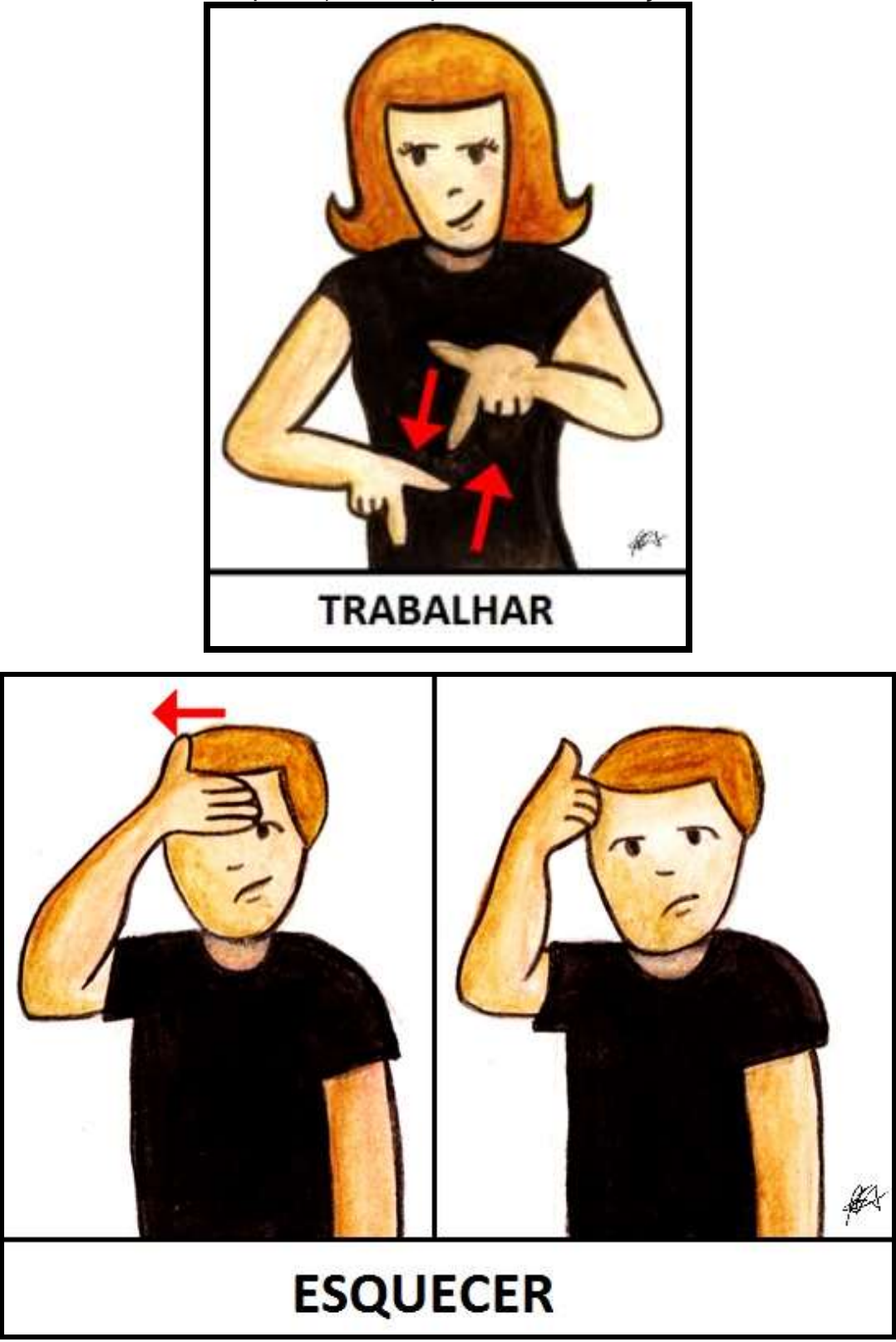

Fonte: Imagem elaborada pela pesquisadora Beatriz Crittelli 
Movimento - $\mathrm{M}$ - indica qual tipo de movimento cada sinal realiza, como: retilíneo, circular, semicircular, sinuoso, angular etc. Esse parâmetro indica também se o sinal não possui movimento, como pode ser observado na Figura 06 comparativa ( $\mathrm{CHOI}, 2011)$ :

Figura 06: Representação do sinal BRINCAR "Mãos em Y, palmas para dentro, inclinadas uma para a outra. Movê-las em pequenos círculos verticais alternados" (CAPOVILLA \& RAPHAEL, 2006, p.318) com movimento e sinal EM-PÉ "mão esquerda horizontal aberta, palma para cima, dedos para a direita; mão direita em $V$ invertido, palma para dentro, dedos para baixo, com pontas dos dedos tocando a palma esquerda." (CAPOVILLA \& RAPHAEL, 2006, p. 578) que não possui movimento.

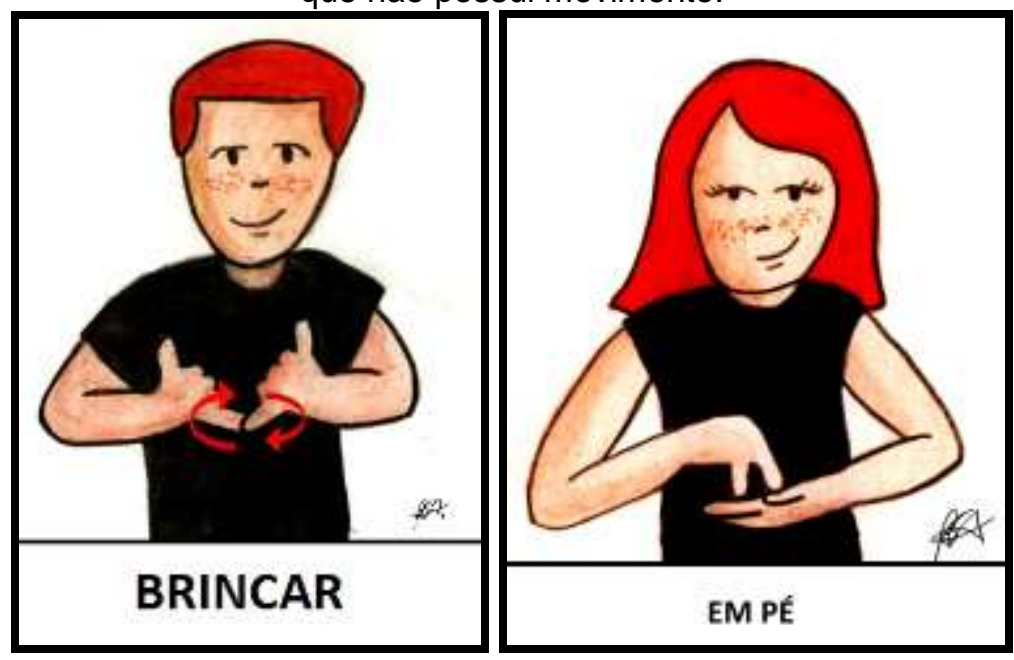

Fonte: Imagem elaborada pela pesquisadora Beatriz Crittelli

A imagem, a seguir, mostra alguns possíveis movimentos executados nos sinais:

Tabela 01: Tabela com descrição de movimentos possíveis na Libras

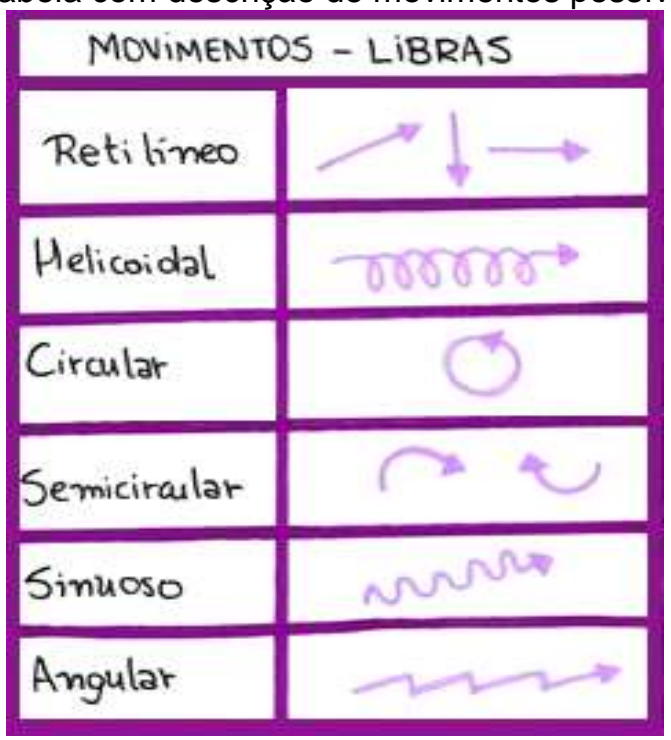

Fonte: Imagem elaborada pela pesquisadora Beatriz Crittelli 
A orientação das palmas das mãos - OPM - faz referência a qual deve ser a direção das palmas das mãos: para baixo, para cima, para frente, para trás, para o lado direito ou esquerdo $(\mathrm{CHOI}, 2011)$ :

Figura 07: Representação do sinal DOCE com a orientação da palma da mão para dentro "mão direita em B, palma para dentro, dedos inclinados para a esquerda, diante da boca aberta. Movê-las em círculos verticais para a esquerda. " (CAPOVILLA \& RAPHAEL, 2006, p.558).

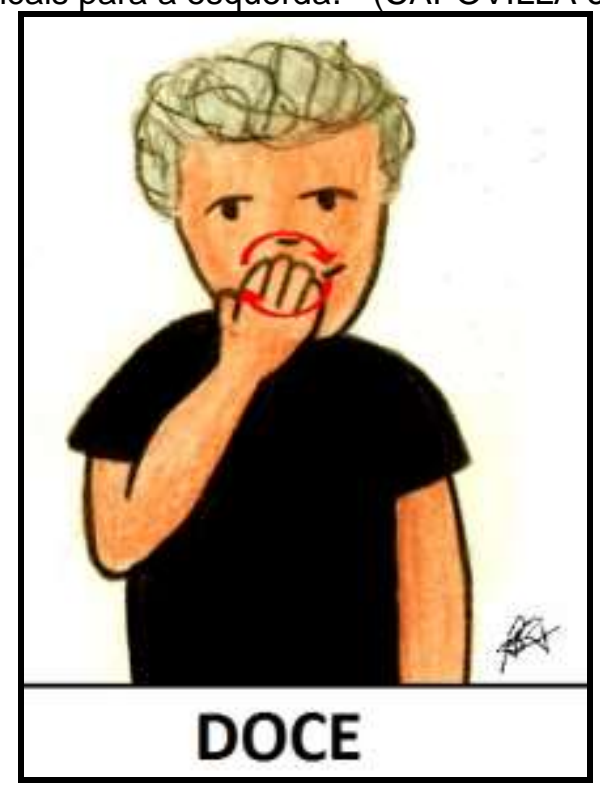

Fonte: Imagem elaborada pela pesquisadora Beatriz Crittelli

A face e o movimento do corpo são muito importantes para a execução da Libras, principalmente quanto à sua expressão para os sinais, por isso, um dos parâmetros está relacionado às expressões faciais e corporais, ou seja, expressões não manuais. Dependendo de como esse parâmetro é utilizado, o sinal pode adquirir um novo sentido, por exemplo, expressando ironia, intensificando o sentido de uma frase ou indicando exclamação, interrogação, afirmação ou negação de uma frase. Um exemplo de expressão não manual pode ser observado no sinal de CONFUSÃO, indicado com o sinal manual e também com a expressão facial desse sentimento (Figura 08): 
Figura 08: Representação do sinal CONFUSÃO "mãos horizontais abertas, palmas para dentro, entrelaçadas pelos dedos, diante do peito. Balançar as mãos para cima e para baixo, virando a cabeça para a direita e para a esquerda. Expressão facial negativa. " (CAPOVILLA \&

RAPHAEL, 2006, p.448).

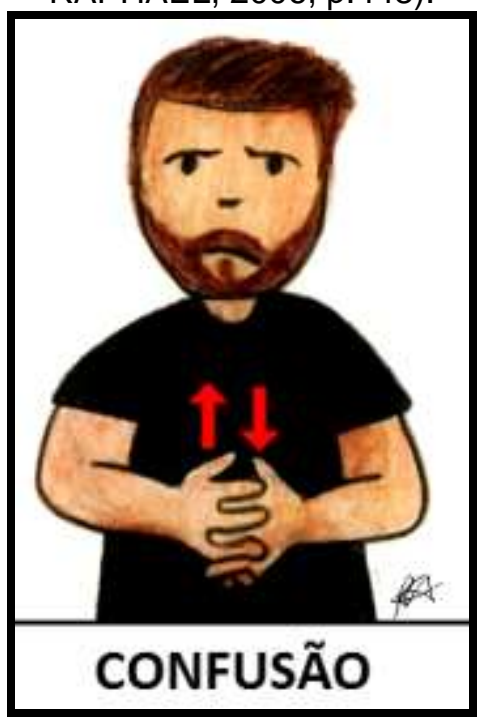

Fonte: Imagem elaborada pela pesquisadora Beatriz Crittelli

Todos esses parâmetros, em conjunto, formam o sinal. Se, em um mesmo sinal, algum desses parâmetros for alterado, ele acaba assumindo um significado diferente, mudando o sentido.

Para a descrição de um sinal, os parâmetros são utilizados, assim como é possível observar na Figura 09 com a descrição do sinal PROFESSOR:

Figura 09: Representação do sinal PROFESSOR de acordo com os cinco parâmetros.

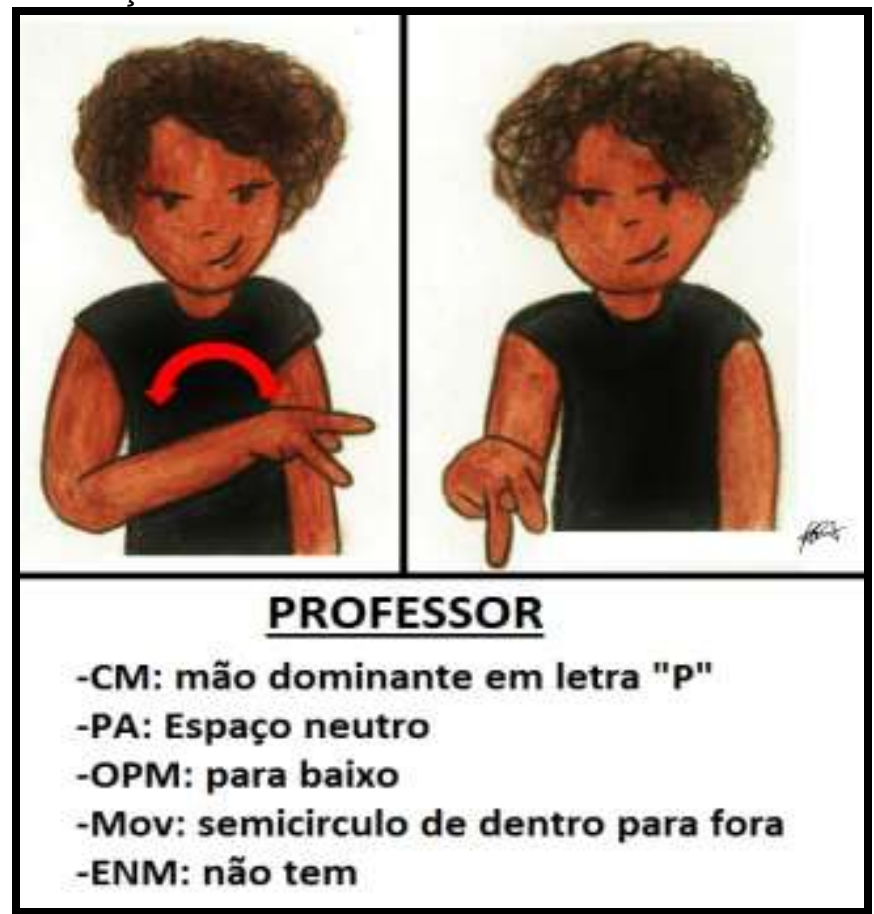

Fonte: Imagem elaborada pela pesquisadora Beatriz Crittelli 


\subsubsection{Aspectos Básicos da Libras}

Nesse tópico, serão abordados diferentes aspectos básicos da Libras que descreverão de uma forma mais específica a compreensão da totalidade viso-espacial que esta língua envolve.

\subsubsection{Iconicidade e Arbitrariedade}

Erroneamente, algumas pessoas pensam que a língua de sinais se resume a representações mímicas de objetos, mas como língua, os sinais podem representar conceitos abstratos que não remetem necessariamente a uma imagem concreta.

Os aspectos de iconicidade e arbitrariedade se referem ao significado do sinal. A maioria dos sinais da Libras são arbitrários, ou seja, não apresentam uma conexão de forma e significado com aquilo que o sinal representa, porém, os sinais que visualmente representam o objeto ou uma ação são denominados icônicos (QUADROS; KARNOPP, 2004).

A figura a seguir mostra um exemplo de um sinal icônico ESCOVAR DENTES "Mão direita em A horizontal, palma para baixo, apontando para a esquerda, diante da boca aberta com os dentes cerrados. Mover ligeiramente a mão para a direita e para a esquerda. " (CAPOVILLA \& RAPHAEL, 2006, p. 602) e um sinal arbitrário CONVERSAR "Mão esquerda horizontal fechada, palma para baixo, apontando para frente, mão direita horizontal aberta, palma para baixo, dedos apontando para a esquerda e tocando o dorso da mão esquerda. Mover a mão direita em círculos horizontais. " (CAPOVILLA \& RAPHAEL, 2006, p.461), que não faz alusão ao seu referente (Figura 10): 
Figura 10: representação de sinais icônicos e arbitrários.
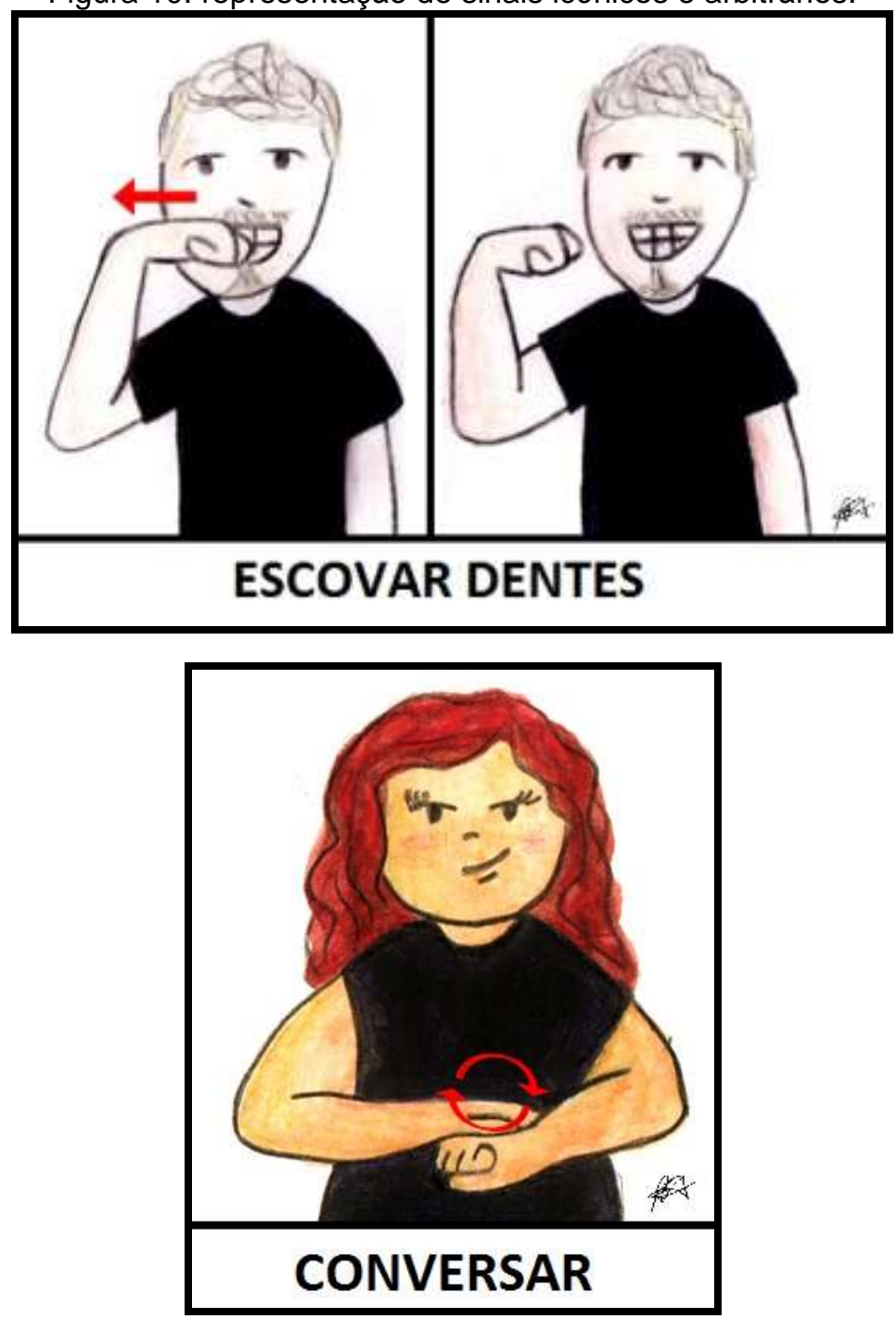

Fonte: Imagem elaborada pela pesquisadora Beatriz Crittelli

\subsubsection{Fonologia}

A fonologia atém seus estudos aos fonemas, sendo estes traços distintivos nas línguas orais quando comparadas às línguas de sinais. Porém, mesmo configurando-se de maneiras diferentes, ambas as línguas possuem fonemas. 
Alguns autores defendem que o termo correto que corresponde à língua de sinais é a "Quirologia", com as unidades mínimas denominadas "quiremas" (ou queremas), capazes de diferenciar conceitos na modalidade das línguas de sinais (BORDINHON, 2010). Essa correspondência terminológica pode ser observada na figura 11 :

Figura 11: termos correspondentes nas línguas de sinais e línguas orais.

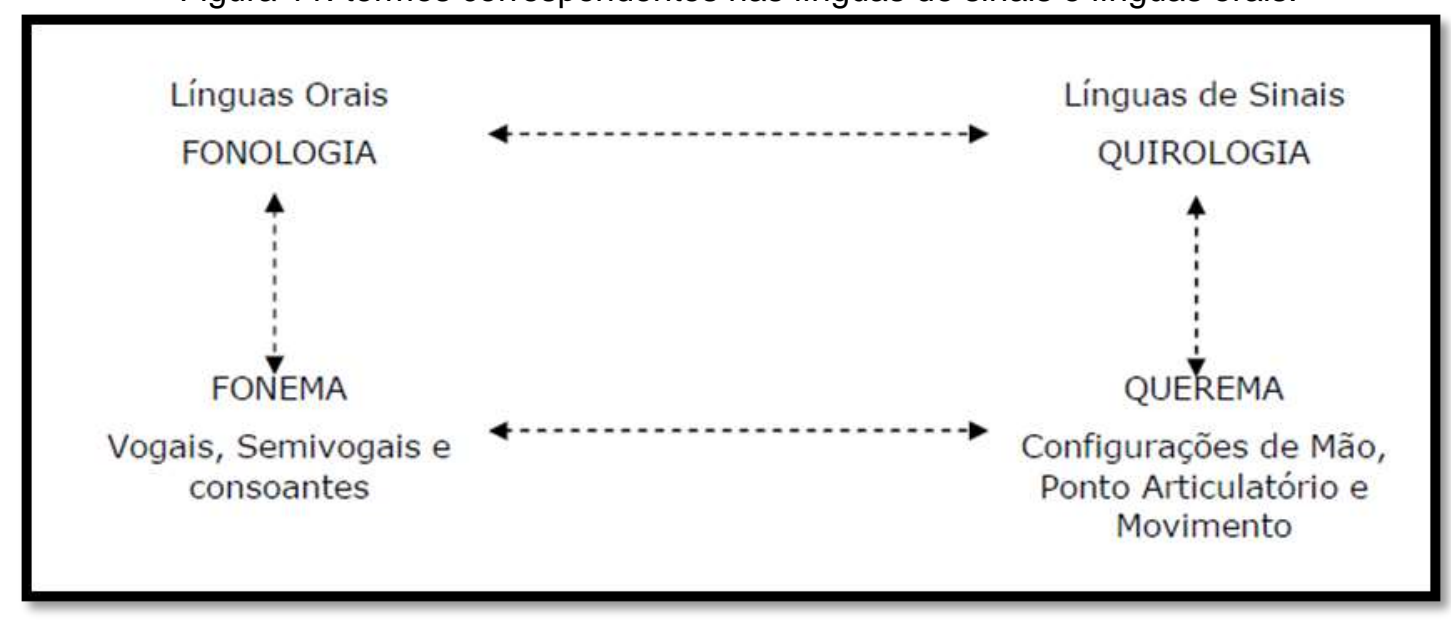

Fonte: Bordinhon, 2010, p.05.

Pode-se dizer que os articuladores primários das línguas de sinais são as mãos, que, por sua vez, movimentam-se no espaço frente ao corpo e executam sinais em determinados pontos dentro desse espaço (KARNOPP, $\mathrm{s} / \mathrm{d})$

A mão direita ou esquerda podem ser utilizadas para executar um sinal, variando de acordo com a mão dominante do indivíduo (KARNOPP, s/d). De acordo com Karnopp, sinais articulados com uma mão são produzidos pela mão dominante e, por sua vez, sinais articulados com as duas mãos também apresentam restrições relacionadas às interações entre ambas as mãos, como por exemplo, uma mão continua sendo a dominante, executando o movimento complexo, enquanto a outra mão pode realizar movimentos e configurações iguais ou permanecer "neutra" (fechada ou aberta).

As línguas de sinais são produzidas pelas mãos, contudo, os movimentos do corpo e da face também desempenham funções, intensificando o sinal ou incorporando a ele a interrogação, negação, afirmação ou exclamação (KARNOPP, s/d). 


\subsubsection{Sintaxe e Semântica}

De acordo com Quadros e Karnopp (2004), a sintaxe se define como "(...) área de estudo que analisa a combinação das palavras para a formação de estruturas maiores (frases)" e a semântica, por sua vez, corresponde à "(...) área de estudo do significado na linguagem".

$\mathrm{Na}$ Libras, a estrutura das frases segue uma ordem diferente das línguas orais. Explicando de uma forma resumida, enquanto nas línguas orais se têm frases construídas habitualmente por "Sujeito + Verbo + Objeto" - SVO, na Libras, há possibilidade de outras sentenças gramaticais com estruturas como: "Sujeito + Objeto + Verbo" e "Verbo + Objeto + Sujeito" e, principalmente, "Objeto + Sujeito + Verbo" (SANTOS et al., 2013).

Quadros e Karnopp (2004, p. 139-156) apontam alguns aspectos na estruturação de frases na Libras, como: as expressões não manuais são fundamentais para a estruturação das frases e sua concordância; "numa relação entre verbo e objeto não pode haver uma interrupção dos advérbios temporais e de frequência" e também, a ordem "Sujeito + Verbo + Objeto" possibilita a omissão dos sujeitos e objetos.

Como citado anteriormente, Santos et al. (2013) reforça que as derivações de estrutura de frase são possíveis por conta da utilização de marcas como a concordância e as expressões não manuais, as quais devem "(...) ser analisadas com aprofundamento para sua real compreensão" (SANTOS et al., 2013, p. 15).

\subsubsection{Classificadores}

De acordo com Campello (2008), classificador pode ser descrito como uma maneira de explicar um acontecimento em Libras a partir da descrição imagética, utilizando uma maneira diferente dos sinais comumente representados. A autora indica que "[o] objetivo é utilizar captação dos sinais 
visuais, ampliar e exercitar as capacidades mentais e visuais para se comunicar com os Surdos" (CAMPELLO, 2008, p. 209).

O espaço neutro, localizado frente ao tronco do corpo, é utilizado para marcar e identificar pontos de acordo com o acontecimento que está sendo descrito em Libras, para as construções gramaticais com verbos espaciais e de concordância, e também para a realização de construções usando classificadores (BERNARDINO, 2012).

Bernardino (2012) afirma ainda que os classificadores são responsáveis pela formação de grande parte dos sinais já existentes, além de serem também responsáveis pela criação de novos sinais. A pesquisadora também alega que, na maioria das vezes, os classificadores são representados de forma icônica e, para os leigos, pode lembrar alguns gestos que acompanham a fala. Por conta disso, classificadores podem ser confundidos com gestos quaisquer, ainda que possuam regras para sua estruturação e distintas características (BERNARDINO, 2012).

Mãos e corpo são usados como meios para indicar o sinal do referente ou o agente da ação representada, incluindo basicamente um movimento dentre uma série característica de movimentos possíveis; uma configuração de mão específica ou outra parte do corpo e, por fim, um direcionamento para esse movimento, podendo ser um caminho ou um traçado (BERNARDINO, 2012).

A tabela, a seguir, indica imagens com exemplos de configurações de mãos e suas respectivas aplicações nos classificadores (Tabela 02): 
Tabela 02: Descrição de configurações de mãos e seu uso mais frequente na Libras.

\begin{tabular}{|c|c|}
\hline $\begin{array}{r}\text { Confi } \\
\text { m }\end{array}$ & Usos e exemplos \\
\hline $\boldsymbol{Y}$ & $\begin{array}{l}\text { Usada para representar uma pessoa gorda andando, objetos largos de forma } \\
\text { irregular (como telefone, bule de café, salto de sapato, ferro de passar roupas, } \\
\text { avião, submarino, chifre de boi), roupas, alimentos e outros objetos em uma } \\
\text { casa. }\end{array}$ \\
\hline$B$ & $\begin{array}{l}\mathrm{CM} \text { com algumas variações quanto ao dedo polegar estendido ou não, usada } \\
\text { para representar coisas planas, lisas ou superficies onduladas (como veículos, o } \\
\text { telhado de uma casa, um pé num sapato, um livro, uma casa ou rodas de } \\
\text { trem[?]). }\end{array}$ \\
\hline G1 & $\begin{array}{l}\text { Usada para descrever formas lineares, para indicar lugares usando a ponta do } \\
\text { dedo e para representar objetos longos e finos (uma pessoa, um poste, um } \\
\text { prego, rabo de animais). }\end{array}$ \\
\hline$F$ & $\begin{array}{l}\text { Usada para representar pequenos objetos cilíndricos (como moedas, botões, } \\
\text { uma gota de água), para mostrar o modo de segurar objetos pequenos e finos e } \\
\text { usando as duas mãos para descrever objetos cilindricos longos (como um cano } \\
\text { fino) }\end{array}$ \\
\hline$A(S)$ & $\begin{array}{l}\text { Usada para segurar objetos (como uma faca, um guarda-chuva ou um } \\
\text { ramalhete de flores). }\end{array}$ \\
\hline $\boldsymbol{V}$ & $\begin{array}{l}\text { Usada para representar pessoas (uma pessoa caminhando }-V \text { com as pontas } \\
\text { dos dedos para baixo, ou duas pessoas em pé }-V \text { com as pontas dos dedos para } \\
\text { cima). }\end{array}$ \\
\hline 5 & $\begin{array}{l}\text { Usada como um substituto do substantivo, pode referir-se a várias entidades } \\
\text { (plural) ou somente uma entidade (sem exemplos). }\end{array}$ \\
\hline
\end{tabular}

Fonte: Bernardino, 2012 apud Ferreira-Britto, 1995, p. 107 - 112.

\subsubsection{Aquisição da língua}

Strnadová (2000) afirma que uma criança Surda não compreende fonemas e não sabe como pronunciá-los oralmente, essa tarefa só é possível através de um trabalho árduo para a criança e para os profissionais, como pedagogos e também fonoaudiólogos. Até conseguir pronunciar uma palavra, leva-se tempo, e a visão e tato não são suficientes para substituir a audição, assim a qualidade sonora fica prejudicada (STRNADOVÁ, 2000). 
Quando aprendem os fonemas, as crianças Surdas devem aprender o conjunto deles para formar palavras e, depois, o que essas palavras significam para os ouvintes, já que para essa criança, o que ela fala com a voz não significa nada (STRNADOVÁ, 2000).

Muitas famílias a submetem a este processo, mesmo com o conhecimento dessas informações, com a justificativa de que a criança está em um mundo ouvinte e precisa se adaptar a essa sociedade. A justificativa de que uma população minoritária como os Surdos não pode exigir da sociedade ouvinte que aprenda língua de sinais não leva em consideração o quão forçoso e árduo é o trabalho de oralização de um Surdo em comparação a um ouvinte que aprende uma língua de sinais.

Um Surdo que deseja ser oralizado possui liberdade para recorrer a um profissional da fonoaudiologia para solicitar e desenvolver essa habilidade, com a consciência de que, mesmo quando esse trabalho ocorre de livre e espontânea vontade, exige um trabalho árduo de treinamento. A questão é: um Surdo que não deseja ser oralizado deve se submeter ao discurso de que ele é minoria e precisa aprender a falar oralmente ou deve lutar por uma sociedade em que todos os indivíduos, sejam eles Surdos ou ouvintes, tenham contato com a língua de sinais e condições igualitárias de acesso à informação?

Como pôde ser constatado no capítulo referente ao perfil histórico, por muitos anos os Surdos foram mundialmente privados de utilizar as línguas de sinais, com a justificativa, entre outras, de que as LS atrapalhavam 0 desenvolvimento e aprendizado das línguas orais. Vale ressaltar que muito tempo se passou até que essa ideia fosse superada, resultando em concepções inapropriadas sobre a educação de Surdos e aquisição da LS, as quais continuam impregnadas até os dias atuais.

A aquisição da língua de sinais, atualmente considerada como a mais adequada para a criança Surda (PIZZIO; QUADROS, 2011), ocorre em parte de maneira diferente e em parte semelhante da aquisição da língua oral por uma criança ouvinte. A criança ouvinte, desde o nascimento, capta sons e percebe barulhos diferentes no ambiente, naturalmente distinguindo tais sons e iniciando uma comunicação. A criança Surda pode até perceber movimentos de fala oral, porém não consegue captar sons, necessitando de ser estimulada desde cedo a se comunicar com sinais, mas uma família ouvinte que não 
possui o conhecimento da língua de sinais não faz essa estimulação e, mesmo que use "mímicas" e demais gestos para se comunicar com a criança, não faz a estimulação correta para que ela aprenda Libras.

Algumas famílias deixam esse trabalho de ensino e estimulação ao uso da língua de sinais para as escolas e consultas a fonoaudiólogos, porém, esse trabalho deveria ser constante e realizado desde cedo para a criança conseguir se expressar e comunicar-se corretamente.

O contato com a comunidade Surda permite que flua esse processo de aquisição da língua, no entanto, não deve ser restrito a ela, sendo necessário que a língua seja utilizada entre os membros da família, auxiliando no processo educacional e de construção de identidade da criança Surda (GESUELI, 2006).

Quando a língua é adquirida tardiamente, pode acarretar problemas psicológicos de comunicação e formação de identidade para a criança Surda. A aquisição pode ocorrer em escolas, igrejas, associações, e demais lugares frequentados pela comunidade Surda, através da interação com seus pares. Ou seja, por meio do contato com outras pessoas Surdas, assim como ocorre com crianças ouvintes (GESUELI, 2006).

Quando a criança Surda nasce em um lar com pais Surdos, ela já recebe os estímulos em língua de sinais desde pequena, porém, essa não é a realidade da maior parte dos Surdos brasileiros, já que 95\% das famílias são compostas por pais ouvintes. Isso impõe para as crianças Surdas uma aquisição de língua tardia, se comparado com as crianças ouvintes, uma vez que leva-se muito tempo para que as famílias aprendam a língua de sinais (PIZZIO; QUADROS, 2011).

A fase de aquisição de língua para a criança Surda se assemelha a das crianças ouvintes quando, por exemplo, Surdos nascidos em famílias Surdas adquirem as regras gramaticais da língua de sinais semelhantemente a crianças adquirindo a língua oral, percebendo-se, com isso, que a constituição da gramática para uma criança em fase de aquisição de língua independe das modalidades e variações que as línguas possuem (PIZZIO; QUADROS, 2011).

Por volta dos 14 meses de idade, os gestos que a criança Surda produz começam a se diferenciar, como se fosse um balbucio para uma criança ouvinte, e até os dois anos, as crianças Surdas apontam os objetos, porém, essa "apontação" não segue o padrão da língua de sinais, mas, quando a 
criança entra no estágio de um sinal, a apontação desaparece (PIZZIO, QUADROS, 2011 apud PETITTO, 1987).

Na média dos dois anos de idade, aparecem as primeiras combinações de sinais. Pizzio e Quadros (2011, p. 05), citados por Petitto (1987), sugerem que, durante esse período: “(...) ocorre uma reorganização básica em que a criança muda o conceito da "apontação" inicialmente gestual (pré-lingüística) para visualizá-la como elemento do sistema gramatical da língua de sinais (lingüístico)".

As similaridades que existem em comparação às línguas de sinais e orais podem indicar uma "(...) existência de propriedades do sistema linguístico que transcendem a modalidade das línguas" (PIZZIO; QUADROS, 2011, p.08) e, com isso, a evolução dos estudos na área de língua de sinais apresenta cada vez mais elementos que confirmam princípios que reafirmam essas línguas como línguas humanas.

Entre os estudos de aquisição de língua, Pizzio e Quadros (2011) apontam que os estudos das línguas de sinais são de extrema relevância, dado que há uma preocupação em relação aos efeitos das diferenças nas modalidades, mas afirmam que ainda há muito a ser investigado.

\subsubsection{Libras e Ciências}

Os temas ligados às Ciências Naturais, para serem compreendidos, em geral exigem uma grande capacidade de abstração de conteúdos que nem sempre os alunos de Ensino Fundamental II possuem, por estarem em uma fase do desenvolvimento em que essa capacidade ainda não foi alcançada (SIVIANI, 1985). Essa questão é ainda mais prejudicada quando o professor organiza as aulas de modo que predomine a "transmissão de informações", sem que os alunos se envolvam ativamente no processo de aprendizagem.

Professores encontram grandes dificuldades em atuar com alunos ouvintes e alunos Surdos nas salas comuns. Dentre as dificuldades, destacamse: a formação docente deficiente na temática; os erros conceituais em livros 
didáticos; a falta de material de apoio para os docentes e a falta de formação para atuar com o aluno Surdo. Tais aspectos fragilizam a implementação dos conteúdos no Ensino Regular (MENDES, 2006; LANGHI, 2010; MENEZES et al., 2010; PEIXOTO; RAMOS, 2011).

A esse respeito, Glat e Lima (2003) ressaltam que a formação docente tradicional reforça o conceito errôneo de normal-anormal, privilegiando, assim, conteúdos que atendem a uma particularidade do ensino. Em consequência dessa dicotomia, não é de se espantar que ainda não exista uma integração efetiva de alunos com deficiência no sistema regular de ensino. O professor imerso nesse contexto necessita ser preparado para lidar com as diferenças, com as especificidades de cada caso em conjunto com a diversidade deles e não com um modelo de pensamento comum a todas elas, pois esse modelo não existe.

Isso gera um sistema complexo em que professores não se veem preparados para atuar com alunos do público alvo da Educação Especial, caindo a culpa na formação docente inicial. Porém, qual seria a real formação docente necessária para efetivamente preparar esses professores? Implementar algumas disciplinas na área poderia ajudar a sensibilizá-los a estudar mais sobre esse tema, entretanto, esse problema está longe de ter uma solução ideal.

A perspectiva de uma escola com salas de aula comuns que realmente incluam o aluno Surdo está sendo trilhada aos poucos, no entanto, para os alunos que já estão ocupando as escolas, há urgência. Algo precisa ser feito por eles ao invés de ignorarem a situação com a justificativa de que os professores de salas comuns não podem atuar com esses alunos por não serem suficientemente preparados em seu período de formação inicial. Esse contexto se repete nas escolas bilíngues nas quais, ainda que o professor esteja diariamente lidando com o público de alunos Surdos e seja teoricamente preparado para isso, outras particularidades são agregadas ao seu dia-a-dia, assim como nas escolas com salas de aula comuns, como por exemplo, lidar com a indisciplina em sala, problemas familiares que refletem no aprendizado, dificuldades cognitivas, entre outros.

Quando se depara com a sala de aula, o professor no contexto bilíngue deve levar em consideração em seu planejamento de aulas toda a diversidade 
que marca esse contexto, com salas heterogêneas, diversas expressões, culturas e, além de tudo, duas línguas completamente diferentes: o português e a Libras. Esse é um trabalho árduo, pois, nesse processo, nada deve ser desconsiderado e muito menos desvalorizado, ao mesmo tempo em que se deve encontrar um equilíbrio na execução de suas tarefas educacionais como professor.

Durante a investigação, planejamento e revisão dos conteúdos e da sua prática, o professor deve ser extremamente rigoroso para que não transmita uma informação equivocada e reduzida sobre a natureza e o sentido do fenômeno científico que é encontrado em alguns materiais bilíngues, isso pode trazer sérias consequências de aprendizado aos alunos Surdos e, também, aos ouvintes (ALVES; PEIXOTO; LIPPE, 2013).

Tendo a Libras como elemento central nas salas bilíngues, levando-se em conta que esta é uma língua viso-espacial, os Surdos podem estar mais familiarizados com sinais representados por meio de desenhos. Sendo assim, os dicionários podem facilitar a aprendizagem de sinais novos ou ser usado para tirar dúvidas, mas a consulta a um sujeito fluente em Libras pode ser necessária para se confirmar a correta realização dos movimentos ou o significado descrito em português (SOFIATO; REILY, 2014). Nesse caso, o instrutor presente nas escolas bilíngues pode exercer esse papel.

$\mathrm{Na}$ preparação e planejamento da aula ou elaboração de material didático, os professores, tradutores e intérpretes de Libras (TILS) recorrem, para fins de consulta, aos dicionários bilíngues de Libras. Porém, caso não encontre o sinal correspondente ou caso não haja uma interpretação adequada dos conceitos/verbetes ali encontrados, os alunos, ao longo do processo de ensino/aprendizagem, podem internalizar conceitos com sentidos completamente diferentes do que é aceito como correto, acarretando, portanto, um sério dano à formação dessas pessoas.

Cabe ressaltar que a Libras é uma língua regulamentada recentemente no país (BRASIL, 2002) e, assim como as línguas orais, ela evolui conforme a popularização de seu uso em diversos meios, havendo constantemente a necessidade de pessoas Surdas criarem novos sinais. Porém, o ensino de ciências não pode se limitar pela "falta" de vocabulário científico em Libras e 
muito menos, por conta disso, desvalorizar a língua como algo não passível de estabelecer uma comunicação plena entre pares.

$\mathrm{Na}$ área de ciências, encontra-se uma necessidade de sinais referentes a termos específicos de ciências. Tal ausência pode levar a uma criação controversa de um sinal relacionado a um conceito científico, podendo, para um mesmo conceito científico, ser encontrada uma variedade de sinais, permitindo, inclusive, distorções e interpretações equivocadas sobre estes conceitos (ALVES; PEIXOTO; LIPPE, 2013).

A ausência de sinais específicos na área científica, de acordo com Alves, Peixoto e Lippe (2013), indica que os alunos Surdos deixam de ter a oportunidade de conhecer de uma forma aprofundada os conteúdos que devem ser ensinados durante o Ensino Fundamental e Médio, podendo prejudicar, assim, a sua entrada na universidade.

Nas aulas de ciências, o professor pode se deparar com dificuldades durante uma explicação de conteúdo com termos científicos para os quais não existem sinais correspondentes na Libras. Primeiramente, a Libras é uma língua desvinculada do português. Ao se traduzir uma frase em português, por exemplo, não se deve interpretar palavra por palavra e, sim, representar de acordo com a própria estrutura correspondente à língua de sinais o significado daquela frase, com os sinais mais adequados para tal. Outro aspecto importante para a reflexão dentro desse tema é que a Libras, por ser uma língua viso-espacial, pode representar situações dentro de um espaço e não linearmente, como nas línguas orais, assim, um fenômeno natural, por exemplo, não necessita de nomes específicos para ser explicado em sala, podendo sua ocorrência ser representada espacialmente.

Para algum termo científico específico que o professor for utilizar constantemente, ele pode, em conjunto com seus alunos Surdos, construir um sinal para tal a partir de sinais já existentes. Assim, combinando o sinal com seus alunos, toda vez que executar aquele sinal, estará representando o conceito científico que, em português, possui um nome específico. Isso possibilita aos alunos o papel ativo em sala na construção de conceitos científicos, porque até se chegar a um sinal, há muita negociação e troca de informações. Dessa forma, o professor deve estar constantemente exercendo o 
papel de mediador para que, nessa construção, não ocorram equívocos conceituais.

A prática de combinar sinais é uma maneira interessante de se trabalhar com os alunos Surdos num contexto bilíngue, mas não descarta o fato de que a criação dos sinais deve ser universalizada para que não ocorram várias criações pontuais pelo país com o consenso de diferentes sinais formados a partir do mesmo conceito.

Utilizar classificadores para explicar conceitos científicos é utilizar um elemento da própria língua de sinais para expressar um fenômeno, representar uma cena de ação, seres vivos, dentre outros elementos (assim como pode ser observado no Apêndice 12). Para uma pessoa se apropriar do uso de classificadores, é necessário que se tenha um bom domínio da língua de sinais, pois essa tarefa exige que a pessoa faça um bom uso do espaço e dos aspectos visuais que cada conceito carrega. Mas, mesmo que os classificadores sejam uma forma interessante de se trabalhar ciências, para alguns conceitos é necessário que exista um sinal específico. Por exemplo, a fotossíntese pode ser representada por classificadores, mas se um intérprete estiver interpretando uma aula e surgir esse termo, ele precisará de um sinal correspondente porque não há tempo para fazer uma representação com classificadores, já que a aula segue e ele precisará continuar interpretando o conteúdo falado.

Outra possível prática é a utilização de "sinais-termo". Criado por Faulstich (2014), corresponde às necessidades do uso especializado de sinais da Libras de acordo com as diferentes áreas do conhecimento, como, por exemplo, as ciências, sendo a palavra "sinal" correspondente aos sinais da Libras e "termo", ao conceito correspondido (PROMETI; COSTA; TUXI, 2015).

Para a elaboração dos sinais-termo, há um procedimento rigoroso que passa pelas seguintes etapas: reconhecimento e identificação do público alvo; delimitação das áreas pesquisadas; coleta e organização dos dados; organização do glossário e teste de validade (PROMETI; COSTA; TUXI, 2015). Tais procedimentos são realizados a partir de estudos na área do conhecimento escolhida e dos conceitos envolvidos. Além disso, Surdos fazem parte da elaboração dos sinais e das demais etapas do projeto. 
Como exemplo de uma aplicação do sinal-termo, observe-se o que é representado na figura abaixo. Existe o sinal da Libras comumente utilizado para "coração", mas foi criado um "sinal-termo" que corresponde a um conceito científico em que os pesquisadores utilizaram a iconicidade para representar o coração como um órgão:

Figura 12: diferença entre os sinais de CORAÇÃO, o primeiro representando o sinal comum e o segundo o sinal-termo correspondente ao coração como um órgão.

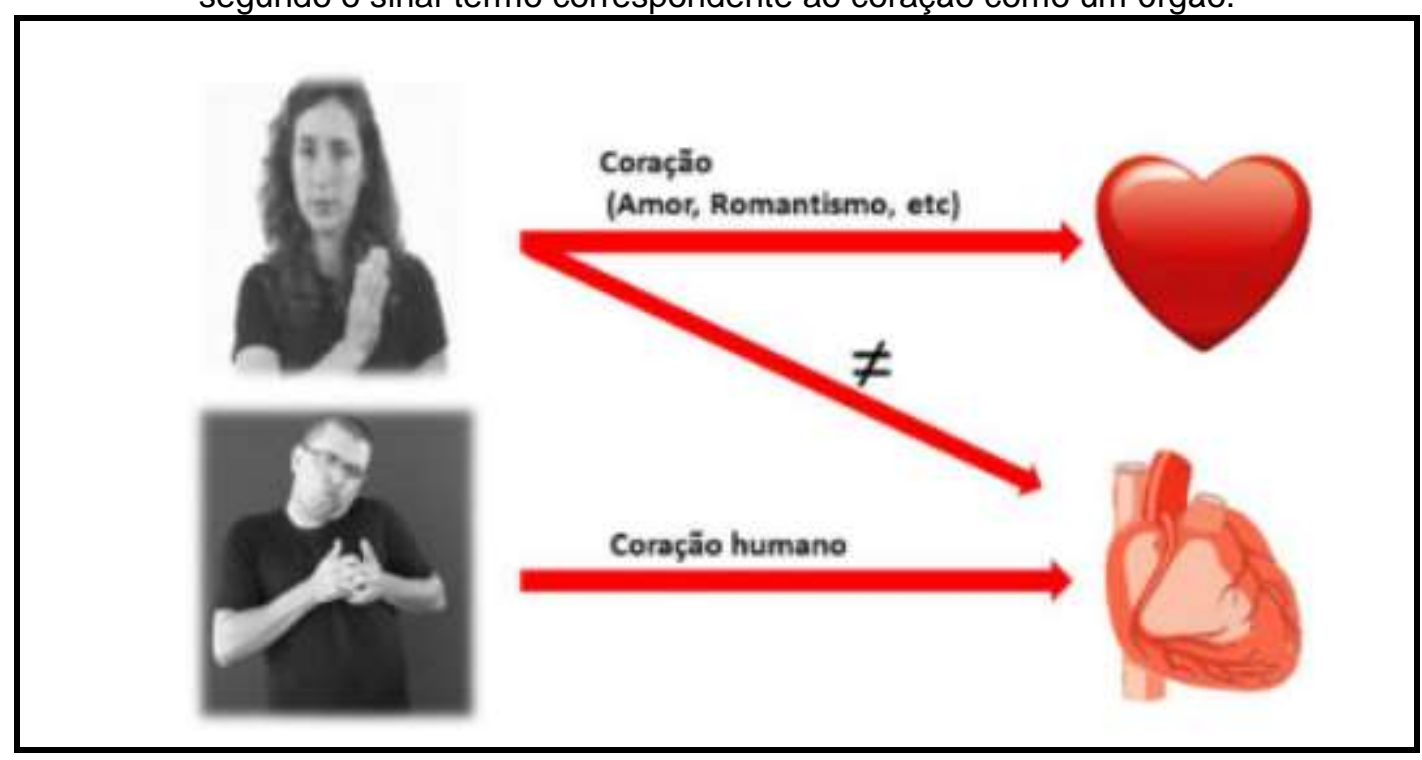

Fonte: COSTA, M. R. Proposta de modelo de enciclopédia visual bilíngue juvenil: Enciclolibras o corpo humano, 2012.

Analisando as aulas de ciências a partir da comparação entre aulas ministradas em Libras e as ministradas em português, durante o processo de construção de um conceito, ocorrem ricas interações e reflexões sobre os conteúdos trabalhados em aula porque as interações partem do abstrato (pensamento) até a construção do concreto (um sinal específico para o determinado conceito). Pode-se destacar que o processo que ocorre em Libras até chegar a um sinal referente a um conceito é uma grande contribuição para a ciência. Em comparação, em aulas ministradas em português, pelo fato de as terminologias já estarem todas enquadradas, prontas e bem fundamentadas, tal processo não ocorre da maneira ideal porque não permite aos alunos uma reflexão acerca de como aquele conceito foi construído.

No contexto de salas comuns, para contribuir com um ensinoaprendizagem significativo, o professor precisa atuar diretamente com os intérpretes e instrutores de Libras, traçando estratégias que alcancem os 
alunos Surdos em salas comuns e preparando os intérpretes com antecedência para os conteúdos de cada aula. Professores de escolas bilíngues devem estar constantemente se dedicando ao estudo da Libras e utilizando não somente uma, mas diversas metodologias de ensino em suas aulas, com a finalidade de enriquecer seu trabalho e possibilitar o máximo possível a aproximação entre os alunos Surdos e o conhecimento científico, não evidenciando sua diferença, mas provando o quanto é perfeitamente possível estudar ciências com essa língua.

Alguns autores apontam que a Libras deve ter um maior aprofundamento científico e que deve-se criar dicionários mais complexos para a divulgação dos sinais, juntamente com uma formação mais ampla dos intérpretes e melhor preparação dos professores. Apesar disso, Caetano e Lacerda (2011) defendem que, mesmo vencendo as barreiras de comunicação, existe um outro importante obstáculo, no caso, a adequação de metodologia e currículo para o estudante Surdo.

De acordo com Vigotski (1999), o aspecto linguístico é fundamental para a compreensão do desenvolvimento do sujeito enquanto ser social, mas para a utilização de uma outra língua, como o português, é necessário garantir que o Surdo tenha condições de se apropriar de sua língua materna, a Libras. É a partir desses pressupostos que este trabalho está fundamentado. 


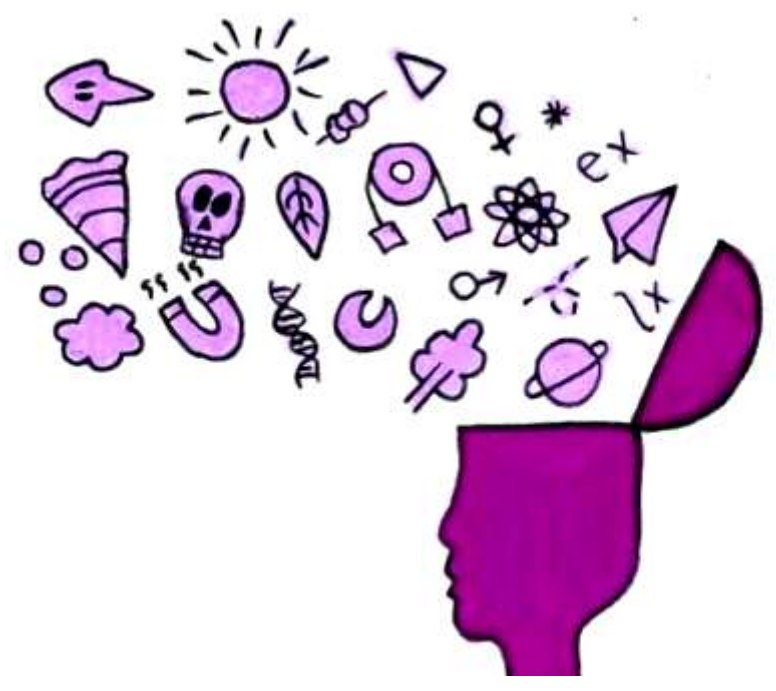

\section{ENSINO DE CIÊNCIAS}

\subsection{Levantamento Bibliográfico}

O levantamento bibliográfico, conforme Galvão (2010, p. 377) define-se como: "potencializar-se intelectualmente com o conhecimento coletivo, para se ir além". Em concordância com a autora, este levantamento bibliográfico tem o intuito de revelar as principais produções acadêmicas na área que segue esta pesquisa, levantando de forma quantitativa o número de produções e qualitativamente o que essas pesquisas abordam.

Com isso, foi realizado o levantamento a partir do uso tanto isolado quanto combinado das seguintes palavras encontradas em título, resumo ou palavras-chave das pesquisas: ensino de ciências e surdez; ensino de ciências para Surdos; ensino de ciências para deficientes auditivos; Libras e ciências.

Não houve uma restrição quanto ao ano de publicação, pois, das teses e dissertações encontradas nessa temática, nenhuma data de mais de 10 anos atrás. 
A consulta se restringiu somente à busca de dissertações e teses nas seguintes plataformas de busca: Biblioteca digital brasileira de teses e dissertações (BDTD); Banco de Teses e Dissertações da Capes (BTDC) e na Biblioteca de Teses e Dissertações da USP.

A restrição com somente trabalhos nacionais se deu por conta desse tema envolver um contexto especificamente linguístico de uma língua brasileira (Libras) e também cultural, tais contextos possuem grande influência na fundamentação teórica e análise de resultados. Além disso, o foco se manteve em teses e dissertações a fim de registrar as pessoas pesquisadoras específicas da área, no caso de artigos, não necessariamente uma pesquisadora ou um pesquisador que redige.

Ao realizar-se a busca pelas palavras-chave mencionadas, percebeu-se um grande número de teses e dissertações que não se relacionavam com a área da educação, sendo que a grande maioria se encontrava na área da saúde, medicina e fonoaudiologia. Essas teses e dissertações foram desconsideradas neste levantamento.

A partir da leitura dos títulos, palavras-chave e resumo, as demais pesquisas foram selecionadas, sendo descartadas aquelas não correspondentes à área proposta. Nesse âmbito, em uma primeira análise para a revisão bibliográfica, foram selecionados 13 estudos: 1 tese e 12 dissertações.

Os trabalhos encontrados foram organizados em uma tabela, separados por veículos de divulgação (tese ou dissertação) e divididos de acordo com a região do Brasil, título, autores, orientador e ano de publicação (Tabela 03):

Tabela 03: organização dos dados referentes ao levantamento bibliográfico.

\begin{tabular}{|c|c|c|c|c|c|}
\hline $\begin{array}{l}\text { Veículo de } \\
\text { divulgação }\end{array}$ & $\begin{array}{c}\text { Região do } \\
\text { Brasil }\end{array}$ & Título & Autor & Orientador & Ano \\
\hline Dissertação & $\begin{array}{l}\text { Brasília - } \\
\quad \text { DF }\end{array}$ & $\begin{array}{l}\text { Aplicação de modelos } \\
\text { qualitativos à educação } \\
\text { científica de Surdos. }\end{array}$ & $\begin{array}{l}\text { Gisele } \\
\text { Morisson } \\
\text { Feltrini }\end{array}$ & $\begin{array}{c}\text { Paulo Sérgio } \\
\text { B. de } \\
\text { Almeida } \\
\text { Salles }\end{array}$ & 2009 \\
\hline Dissertação & Bauru - SP & $\begin{array}{l}\text { Ensino de Física para } \\
\text { pessoas Surdas: o } \\
\text { processo educacional } \\
\text { do Surdo no Ensino } \\
\text { Médio e suas relações } \\
\text { no ambiente escolar. }\end{array}$ & $\begin{array}{l}\text { Fábio de } \\
\text { Souza } \\
\text { Alves }\end{array}$ & $\begin{array}{l}\text { Éder Pires } \\
\text { de Camargo }\end{array}$ & 2012 \\
\hline Dissertação & $\begin{array}{l}\text { São Paulo } \\
\text { - SP }\end{array}$ & $\begin{array}{l}\text { Ensino de Libras com as } \\
\text { mãos: Libras, }\end{array}$ & $\begin{array}{l}\text { Jucivagno } \\
\text { Francisco }\end{array}$ & $\begin{array}{l}\text { Roseli C. } \\
\text { Rocha de }\end{array}$ & 2013 \\
\hline
\end{tabular}




\begin{tabular}{|c|c|c|c|c|c|}
\hline & & bilinguismo e inclusão. & $\begin{array}{l}\text { Cambuhy } \\
\text { Silva }\end{array}$ & $\begin{array}{c}\text { Carvalho } \\
\text { Baumel }\end{array}$ & \\
\hline Dissertação & Bauru - SP & $\begin{array}{l}\text { Uma investigação sobre } \\
\text { o papel do interlocutor } \\
\text { de Libras como } \\
\text { mediador em aulas de } \\
\text { física para alunos com } \\
\text { deficiência auditiva }\end{array}$ & $\begin{array}{l}\text { Thiago } \\
\text { José } \\
\text { Batista de } \\
\text { Almeida }\end{array}$ & $\begin{array}{l}\text { Éder Pires } \\
\text { de Camargo }\end{array}$ & 2013 \\
\hline Tese & $\begin{array}{l}\text { São Carlos } \\
\text { - SP }\end{array}$ & $\begin{array}{l}\text { A Libras no ensino das } \\
\text { Leis de Newton em uma } \\
\text { turma inclusiva de } \\
\text { Ensino Médio. }\end{array}$ & $\begin{array}{l}\text { Sabrina } \\
\text { Gomes } \\
\text { Cozendey }\end{array}$ & $\begin{array}{l}\text { Maria da } \\
\text { Piedade } \\
\text { Rezende da } \\
\text { Costa }\end{array}$ & 2013 \\
\hline Dissertação & $\begin{array}{l}\text { São } \\
\text { Cristóvão - } \\
\text { SE }\end{array}$ & $\begin{array}{l}\text { Ensino de Química e a } \\
\text { Língua Brasileira de } \\
\text { Sinais - Sistema } \\
\text { signwriting (LIBRAS - } \\
\text { SW): Monitoramento } \\
\text { interventivo na produção } \\
\text { de sinais científicos. }\end{array}$ & $\begin{array}{l}\text { Edivaldo da } \\
\text { Silva Costa }\end{array}$ & $\begin{array}{c}\text { Verônica dos } \\
\text { Reis Mariano } \\
\text { Souza }\end{array}$ & 2014 \\
\hline Dissertação & $\begin{array}{l}\text { Campo } \\
\text { Grande - } \\
\text { MS }\end{array}$ & $\begin{array}{l}\text { Inclusão de deficientes } \\
\text { auditivos no Ensino } \\
\text { Médio: Inserção de } \\
\text { atividades } \\
\text { demonstrativas no } \\
\text { ensino de Física. }\end{array}$ & $\begin{array}{c}\text { Lilian Maria } \\
\text { de Assis } \\
\text { Resende }\end{array}$ & $\begin{array}{l}\text { Paulo } \\
\text { Ricardo da } \\
\text { Silva Rosa }\end{array}$ & 2014 \\
\hline Dissertação & $\begin{array}{c}\text { Juiz de } \\
\text { Fora-MG }\end{array}$ & $\begin{array}{c}\text { Reflexões sobre a } \\
\text { formação de } \\
\text { professores de química } \\
\text { na perspectiva da } \\
\text { inclusão e sugestões de } \\
\text { metodologias inclusivas } \\
\text { aos Surdos aplicadas ao } \\
\text { ensino de química. }\end{array}$ & $\begin{array}{l}\text { Cristiane } \\
\text { Lopes } \\
\text { Rocha de } \\
\text { Oliveira }\end{array}$ & $\begin{array}{c}\text { Ivoni de } \\
\text { Freitas Reis }\end{array}$ & 2014 \\
\hline Dissertação & $\begin{array}{l}\text { Londrina - } \\
\text { Paraná }\end{array}$ & $\begin{array}{l}\text { A dicionarização de } \\
\text { termos em língua } \\
\text { brasileira de sinais } \\
\text { (Libras) para o ensino } \\
\text { de biologia: uma atitude } \\
\text { empreendedora }\end{array}$ & $\begin{array}{c}\text { Julio Cesar } \\
\text { Correia } \\
\text { Carmona }\end{array}$ & $\begin{array}{l}\text { Jair de } \\
\text { Oliveira }\end{array}$ & 2015 \\
\hline Dissertação & Bauru - SP & $\begin{array}{c}\text { O processo de } \\
\text { escolarização de } \\
\text { crianças Surdas no } \\
\text { Ensino Fundamental: } \\
\text { Um olhar para o ensino } \\
\text { de ciências articulado } \\
\text { aos fundamentos da } \\
\text { astronomia }\end{array}$ & $\begin{array}{l}\text { Alessandra } \\
\text { Bueno } \\
\text { Ferreira }\end{array}$ & $\begin{array}{l}\text { Éder Pires } \\
\text { de Camargo }\end{array}$ & 2015 \\
\hline Dissertação & $\begin{array}{c}\text { Juiz de } \\
\text { Fora-MG }\end{array}$ & $\begin{array}{c}\text { Proposta alternativa } \\
\text { para a educação } \\
\text { inclusiva a Surdos: } \\
\text { enfoque no conteúdo de } \\
\text { balanceamento de } \\
\text { equações químicas e } \\
\text { estequiometria para o } \\
\text { Ensino Médio. }\end{array}$ & $\begin{array}{c}\text { Jomara } \\
\text { Mendes } \\
\text { Fernandes }\end{array}$ & $\begin{array}{l}\text { Ivoni de } \\
\text { Freitas Reis }\end{array}$ & 2016 \\
\hline Dissertação & $\begin{array}{l}\text { Goiânia - } \\
\text { GO }\end{array}$ & $\begin{array}{l}\text { Sobre a ação Mediada: } \\
\text { Intervenções } \\
\text { Pedagógicas no ensino } \\
\text { de Ciências para Surdos } \\
\text { em sala bilíngue. }\end{array}$ & $\begin{array}{l}\text { Aline Prado } \\
\text { de Oliveira }\end{array}$ & $\begin{array}{c}\text { Anna Maria } \\
\text { Canavarro } \\
\text { Benite }\end{array}$ & 2016 \\
\hline
\end{tabular}




\begin{tabular}{|c|c|c|c|c|c|}
\hline Dissertação & $\begin{array}{l}\text { Lorena - } \\
\quad \text { SP }\end{array}$ & $\begin{array}{l}\text { Ensino de Ciências para } \\
\text { alunos Surdos: } \\
\text { aplicação de modelo } \\
\text { qualitativo baseado em } \\
\text { raciocínio qualitativo } \\
\text { para alunos do Ensino } \\
\text { Fundamental I. }\end{array}$ & $\begin{array}{c}\text { Marco } \\
\text { Aurélio } \\
\text { Tupinambá } \\
\text { Viana Filho }\end{array}$ & $\begin{array}{l}\text { Graziela } \\
\text { Zamponi }\end{array}$ & 2016 \\
\hline
\end{tabular}

Fonte: Quadro elaborado pela pesquisadora Beatriz Crittelli

Com os dados organizados, leituras dos resumos, sumários e referências bibliográficas um segundo quadro foi elaborado com a finalidade de analisar se os pesquisadores utilizam o autor Vigotski em suas discussões.

O autor citado é a base desta pesquisa para se compreender diversas questões que envolvem aprendizagem, como a formação do pensamento a partir da linguagem, formação de conceitos, mediação, entre outros. Viu-se necessário estabelecer uma comparação das produções da área a fim de analisar se Vigotski também norteia os referenciais das pesquisas citadas e quais obras fundamentam suas discussões:

Tabela 04: Relação das teses e dissertações em relação ao uso do autor Vigotski como referencial teórico.

\begin{tabular}{|c|c|c|}
\hline Autor & Utiliza Vigotski & Obras \\
\hline $\begin{array}{c}\text { Gisele Morisson } \\
\text { Feltrini }\end{array}$ & SIM & Pensamento e Linguagem (1934/1993) \\
\hline Fábio de Souza Alves & SIM & $\begin{array}{c}\text { A construção do pensamento e da linguagem } \\
\text { (1939/2001); Fundamentos de Defectologia } \\
\text { (1928/1997) }\end{array}$ \\
\hline $\begin{array}{c}\text { bJucivagno Francisco } \\
\text { Cambuhy Silva }\end{array}$ & SIM & Pensamento e Linguagem (1934/1993) \\
\hline $\begin{array}{l}\text { Thiago José Batista } \\
\text { de Almeida }\end{array}$ & SIM & $\begin{array}{l}\text { A construção do Pensamento e da } \\
\text { Linguagem (1939/2001); Pensamento e } \\
\text { Linguagem (1934/1993); Linguagem, } \\
\text { desenvolvimento e aprendizado (2001). }\end{array}$ \\
\hline $\begin{array}{l}\text { Sabrina Gomes } \\
\text { Cozendey }\end{array}$ & SIM & $\begin{array}{c}\text { Fundamentos de Defectologia } \\
\text { (1928/1997); Linguagem, desenvolvimento e } \\
\text { aprendizagem (2001) }\end{array}$ \\
\hline $\begin{array}{c}\text { Edivaldo da Silva } \\
\text { Costa }\end{array}$ & SIM & $\begin{array}{c}\text { A formação social da mente } \\
\text { (1931/1998); Pensamento e Linguagem } \\
(1934 / 1993)\end{array}$ \\
\hline $\begin{array}{c}\text { Lilian Maria de Assis } \\
\text { Resende }\end{array}$ & SIM & $\begin{array}{c}\text { A formação social da mente } \\
\text { (1931/1998); Pensamento e Linguagem } \\
\text { (1934/1993); A construção do Pensamento e da } \\
\text { Linguagem (1939/2001) }\end{array}$ \\
\hline $\begin{array}{c}\text { Cristiane Lopes } \\
\text { Rocha de Oliveira }\end{array}$ & NÃO & -..- \\
\hline $\begin{array}{l}\text { Julio Cesar Correia } \\
\text { Carmona }\end{array}$ & SIM & Psicologia Pedagógica (1926/2010) \\
\hline $\begin{array}{l}\text { Alessandra Bueno } \\
\text { Ferreira }\end{array}$ & SIM & $\begin{array}{l}\text { Pensamento e Linguagem (1934/1993); } \\
\text { La conscience comme probléme de la } \\
\text { psychologie du comportamet (1925/1994); }\end{array}$ \\
\hline
\end{tabular}




\begin{tabular}{|c|c|c|}
\hline & & $\begin{array}{c}\text { Déficience et défectologie mentale (1931/1994); } \\
\text { The development of academic concepts in } \\
\text { school aged children (1934/1994); Teoria e } \\
\text { Método em Psicologia (1926/1996); } \\
\text { Fundamentos de Defectologia (1928/1997); A } \\
\text { formação social da mente (1931/1998); A } \\
\text { construção do Pensamento e da Linguagem } \\
(1939 / 2001) ; \text { Psicologia Pedagógica } \\
\text { (1926/2010). }\end{array}$ \\
\hline $\begin{array}{c}\text { Jomara Mendes } \\
\text { Fernandes }\end{array}$ & SIM & $\begin{array}{c}\text { Fundamentos de Defectologia } \\
\text { (1928/1997); Pensamento e Linguagem } \\
\text { (1934/1993). }\end{array}$ \\
\hline $\begin{array}{c}\text { Aline Prado de } \\
\text { Oliveira }\end{array}$ & SIM & $\begin{array}{c}\text { A construção do Pensamento e da } \\
\text { Linguagem (1939/2001); Pensamento e } \\
\text { Linguagem (1934/1993). }\end{array}$ \\
\hline $\begin{array}{c}\text { Marco Aurélio } \\
\text { Tupinambá Viana } \\
\text { Filho }\end{array}$ & SIM & Pensamento e Linguagem (1934/1993) \\
\hline \multicolumn{2}{|c|}{ Fonte: Quadro elaborado pela pesquisadora Beatriz Crittelli }
\end{tabular}

Fonte: Quadro elaborado pela pesquisadora Beatriz Crittelli

A partir dos dados levantados pela Tabela 04, pode-se observar que Vigotski é um referencial muito utilizado para pesquisas nessa área, somente a autora Oliveira (2014) não utilizou o autor. Das obras de Vigotski citadas, a maioria dos trabalhos utiliza o livro "Pensamento e Linguagem" (VIGOTSKI, 1934/1993), totalizando nove de treze trabalhos utilizando esse livro como referencial, a saber: Feltrini (2009); Silva (2013); Almeida (2013); Costa (2014); Resende (2014); Ferreira (2016); Fernandes (2016); Oliveira (2016) e Viana Filho (2016).

Através de uma análise dos títulos das teses/dissertações e assuntos dos sumários, observou-se que a citação do autor Vigotski como um dos principais referenciais teóricos de cada pesquisa aparece nos seguintes trabalhos de: Ferreira (2016), no capítulo "Abordagem histórico-cultural: Vigotski"; Resende (2014), no capítulo "Perspectiva teórica histórica cultural", abordando os temas dos instrumentos e signos, pensamento e linguagem, formação de conceitos, zona de desenvolvimento proximal e aprendizagem do aluno Surdo; e, por fim, a autora Cozendey (2013), como um capítulo de fundamentação teórica de sua pesquisa. Nos demais trabalhos, o autor é citado dentro dos capítulos destinados aos temas "Linguagem" e "formação de conceitos", juntamente com outros referenciais da área.

Quanto às datas de publicações, a primeira é datada no ano de 2009 sendo que, nos anos seguintes, houve um aumento de número de teses e dissertações nessa área do conhecimento a partir de 2013. Somente o ano de 
2015 apresentou uma quantidade menor do que os outros anos, que tiveram um padrão de 3 teses/dissertações ao ano, como pode ser observado no gráfico abaixo (Gráfico 01).

Outro levantamento em questão, também expresso no gráfico 01 , revela, dentro das teses/dissertações analisadas, quais áreas do conhecimento científico cada pesquisa aborda. Essas áreas foram delimitadas a partir da leitura dos títulos e palavras-chave dos trabalhos:

Gráfico 01: Quantidades de trabalhos da área de ensino de ciências para surdos em relação às diferentes áreas da ciência.

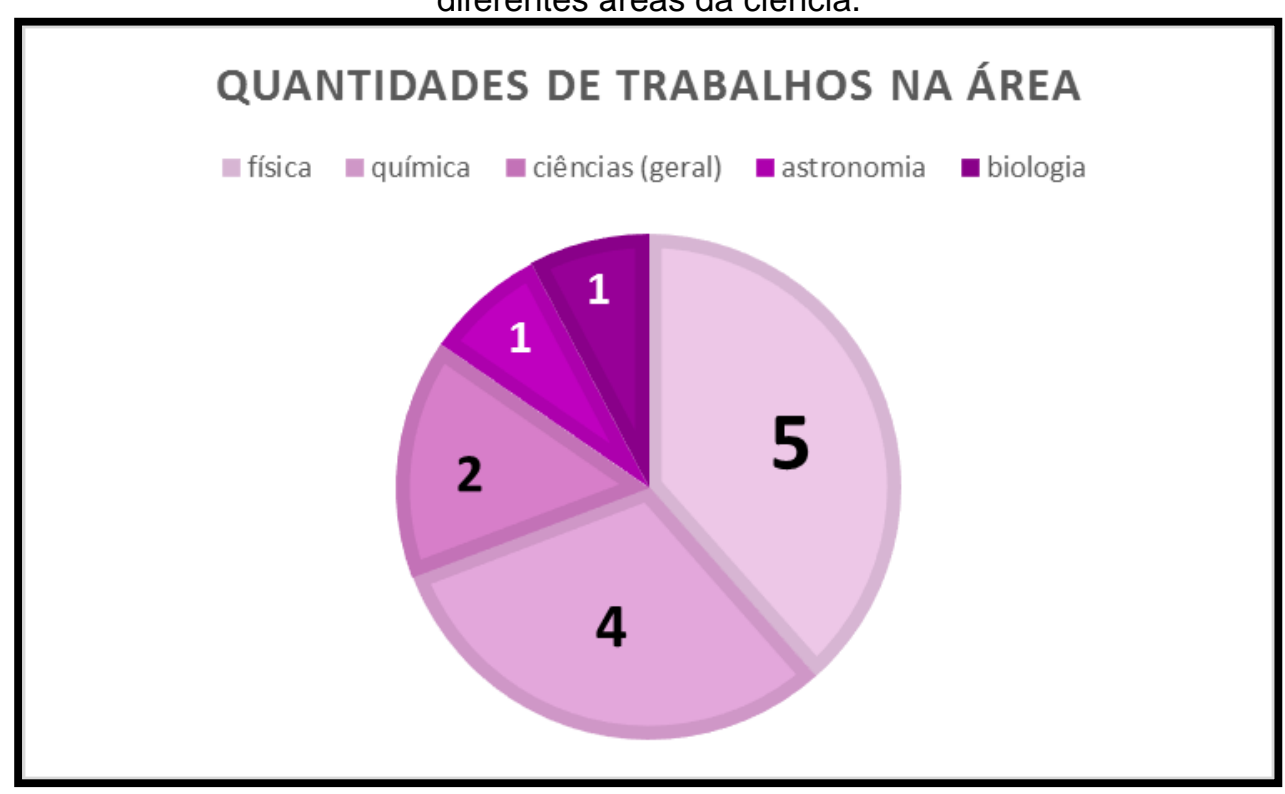

Fonte: Quadro elaborado pela pesquisadora Beatriz Crittelli

Pode-se observar que há uma predominância de trabalhos na área da Física, posteriormente na área da Química, e as áreas do conhecimento que menos apresentam trabalhos são Biologia e Astronomia.

Pela leitura dos resumos, pode-se constatar que as principais áreas do conhecimento nas quais os trabalhos se focaram foram: produção de glossário de conceitos científicos; produção de material didático; observação e análise de uma prática; e propostas de sequências didáticas.

O tema "produção de glossários" foi foco nas pesquisas de Feltrini (2009), Costa (2014) e Carmona (2015), com a justificativa de que a LIBRAS é uma língua que necessita de ampliação de seu vocabulário científico. Vale ressaltar que os glossários foram construídos com a participação direta de Surdos. 
Os pesquisadores Cozendey (2013), Viana Filho (2016) e também Feltrini (2009) focaram seus trabalhos no tema "produção de material didático". Pôde-se constatar que a maior parte dos materiais possuía um cunho tecnológico, com preocupações voltadas para os aspectos visuais e acessíveis a Surdos e ouvintes.

O tema "observação e análise de uma prática" foi o mais abordado, presente na pesquisa de Alves (2012); Silva (2013); Almeida (2013); Ferreira (2016); Resende (2014) e Oliveira (2014). Cada pesquisador apresentou um contexto escolar de educação de surdos diferente (escolas com salas comuns, escolas bilíngues, salas de apoio, entre outros), e também referenciais diferentes, com foco no aluno Surdo, ou no professor, no intérprete, apresentados sob a ótica de diferentes pesquisadores.

Por fim, as pesquisadoras Fernandes (2016), Resende (2014) e Oliveira (2016) propuseram sequências didáticas para trabalhar com Surdos, em contextos de salas comuns de inclusão, sendo que a pesquisadora Oliveira (2016) traz essa proposta para uma escola bilíngue de Goiânia.

De todas as pesquisas analisadas, somente duas, Silva (2013) e Oliveira (2016), trazem o contexto de aplicação de suas práticas em escolas bilíngues para Surdos. As outras pesquisas destinam-se às escolas comuns e também a salas de recursos.

Em vista dos dados apresentados, novamente justifica-se a importância de existirem pesquisas produzidas nessa área do conhecimento. A presente pesquisa caracteriza-se por apresentar contextos pouco ou até mesmo não explorados até então: a análise de uma prática de ensino de biologia para Surdos em uma escola bilíngue de São Paulo, com o foco na interação entre professor ouvinte e aluno Surdo, nas aulas de ciências do Ensino Fundamental II. 


\subsection{Reflexões a partir de Vigotski}

\subsubsection{Linguagem, desenvolvimento e cognição}

Vigotski foi um pesquisador soviético que sugeriu a linguagem como determinante na formação dos processos mentais e na relação entre aprendizagem e o desenvolvimento (ALBRES, 2005).

A obra traduzida como Pensamento e Linguagem (1993) tem como foco refletir sobre a formação do pensamento a partir da linguagem, que se dá pela comunicação em seu intercâmbio social. O autor indica, nessa obra, que o conhecimento relacionado ao pensamento e à palavra são fundamentais para responder questões específicas envolvendo esse tema, mas o significado da palavra aparece como uma das funções da linguagem.

O meio social coloca problemas diante do adolescente em processo de amadurecimento, problemas que "estão vinculados à projeção desse adolescente na vida cultural, profissional e social dos adultos" (VIGOTSKI, 2001, p. 37). Estes são, efetivamente, momentos de extrema importância que tornam a reiterar o que se chama de "intercondicionamento".

De acordo com as concepções de Vigotski (2001), o estímulo que motiva o desenvolvimento do pensamento surge com problemas enfrentados em um determinado contexto social e, com isso, o "problema" torna-se um elemento constituinte do processo de mediação, estabelecendo condições para o enfrentamento de situações (RESENDE, 2014).

A colocação do problema e o surgimento da necessidade de formação de conceito não podem ser vistos como causas desse processo. São fatores que podem desencadear, mas não assegurar a realização do processo de solução de uma dada tarefa.

Para a prática da resolução de um problema, consequentemente há o desenvolvimento das funções mentais superiores. Tal desenvolvimento ocorre através da mediação, utilizando-se de instrumentos e signos, passando a ser 
internalizados pelo indivíduo, ganhando em significado e, por fim, relacionandose ao desenvolvimento da linguagem (RESENDE, 2014).

O uso da linguagem está associado, nas fases iniciais do desenvolvimento humano, à independência sensorial expressa através da fala. A fala, por sua vez, funciona como um sistema simbólico que, associado ao pensamento, expõe uma importante função de rotulação e ordenamento. (RESENDE, 2014).

Para um Surdo, a fala é expressa pela comunicação em sinais, que corresponde a um sistema simbólico comparável à fala oral. É importante ressaltar o quanto a linguagem é fundamental para a formação do pensamento, seja ela oral ou sinalizada. Ou seja, um Surdo privado de falar em língua de sinais desde pequeno pode ter todo esse processo de formação de pensamento prejudicado.

Para Vigotski, a linguagem é um meio de comunicação social, mas também de enunciação e compreensão. A comunicação, quando baseada na compreensão racional e na intenção de transmitir ideias e vivências, exige um sistema de meios em que o modelo de comunicação sempre será a linguagem humana (VIGOTSKI, 1993).

No início do desenvolvimento humano, o pensamento e a linguagem possuem origens diferentes, mas, no decorrer do processo de desenvolvimento, encontram-se de tal forma ligados que, quando o indivíduo chega à fase adulta, são quase sinônimos, podendo-se concluir que, em certa fase da vida, o pensamento não existe sem a palavra (RESENDE, 2014). Porém, para os humanos adultos, a palavra é um instrumento de operação mental (RESENDE, 2014). A autora cita um exemplo de que, nos anos iniciais de vida, a palavra e o conceito não possuem conexão por estarem em seu estado primitivo. Somente quando a palavra é utilizada para a solução de um problema é que ela passa a representar um conceito.

O pensamento estimula e desenvolve a linguagem, na proporção de quanto mais utilizada a palavra ou signo, mais carregada de significado ela se torna, permitindo, futuramente, a formação de conceitos (RESENDE, 2014).

Por sua vez, a linguagem é uma ferramenta básica para a aquisição do conhecimento porque faz parte de um instrumento de operação do 
pensamento, responsável por modificar o desenvolvimento e a estrutura das funções cognitivas (RESENDE, 2014).

Uma concepção do senso comum é que a aprendizagem da criança começa na escola, mas essa concepção não leva em consideração que, desde seus primeiros relacionamentos como indivíduos, as crianças fazem parte, constantemente, de um processo de aprendizagem e desenvolvimento das ações cognitivas na medida em que entram em contato com o meio cultural no qual estão inseridas por meio da linguagem. As relações humanas são sociais, culturais e historicamente construídas, revelando que o indivíduo passa por etapas de desenvolvimento, não desmerecendo a importância da escola como um dos locais mais significativos para a aprendizagem formal dos sujeitos. (RESENDE, 2014).

O pensamento e a palavra surgem, modificam-se e ampliam-se no desenvolver do próprio processo de construção do pensamento e da palavra (VIGOTSKI, 2001). Por sua vez, o pensamento e a linguagem possuem relação externa entre si. Como descreve Vigotski (2001, p. 43), são "duas forças independentes que fluem e atuam paralelamente uma à outra ou se cruzam em determinados pontos da sua trajetória, entrando em interação mecânica".

Vigotski (2001) aponta que há uma falha ao se considerar as relações entre pensamento e palavra como dois processos com elementos autônomos, independentes e isolados, já que é através da unificação externa que faz surgir o pensamento verbalizado, incluindo todas as suas propriedades inerentes.

Para que ocorra a compreensão da linguagem, é necessário que se faça uma cadeia de associações, as quais se originam na mente pela influência das imagens semióticas das palavras (VIGOTSKI, 2001). De acordo com as concepções do autor, a relação entre o pensamento e a linguagem é um processo que se dá do pensamento à palavra e, por sua vez, da palavra ao pensamento, mudando a função primária da linguagem na medida em que aumenta a experiência educacional da pessoa (VIGOTSKI, 2001).

Conforme as crianças vão utilizando a linguagem, novas experiências surgem e novas ideias se constroem de tal maneira que as palavras se tornam o principal agente da abstração e da generalização e, consequentemente, as pessoas passam a fazer cada vez mais uso da classificação para expressar ideias referentes à realidade (VIGOTSKI, 2001). 
O papel do professor perante esse processo consiste em desenvolver não uma única capacidade de pensar, mas diversas capacidades particulares de pensar em diferentes campos e também em não reforçar a capacidade geral de prestar atenção, mas desenvolver diferentes estratégias para se concentrar a atenção perante diferentes matérias (VIGOTSKI, 2001).

Vigotski (2001) exemplifica essa questão com a seguinte comparação: pessoas ouvintes filhas de Surdos (no caso o autor utiliza o termo "Surdosmudos") que não recebem estímulos de fala oral à sua volta, apesar de todos os seus requisitos inatos necessários ao desenvolvimento da linguagem oral, continuam sua vida sem desenvolver esse tipo de fala e não desenvolvem as funções mentais superiores ligadas a esse tipo de linguagem. Do mesmo modo, todo o processo de aprendizagem é como uma fonte de desenvolvimento que ativa e estimula numerosos processos, que não são capazes de desenvolver-se sem que houvesse a aprendizagem (VIGOTSKI, 2001).

Quando passa-se pelo processo da aprendizagem, o significado da palavra se dá de forma inconstante, pois modifica-se no processo do desenvolvimento da criança e, também, através de diferentes modos de funcionamento do pensamento (VIGOTSKI, 2001).

De acordo com as concepções do autor (VIGOTSKI, 2001), uma vez que o significado da palavra pode modificar-se no que diz respeito à sua natureza interior, consequentemente modifica-se também a relação do pensamento com a palavra. Por sua vez, ele define o significado da palavra como "unidade do pensamento e da linguagem (...) indecomponível de ambos os processos e não podemos dizer que ele seja um fenômeno da linguagem ou um fenômeno do pensamento" (VIGOTSKI, 2001, p. 113). Assim, o autor afirma que a palavra desprovida de significado não é palavra, mas apenas um som vazio e, com isso, o significado é "um traço constitutivo indispensável da palavra" (VIGOTSKI, 2001, p.110).

Dizendo de outra forma, o significado da palavra nada mais é que uma generalização ou conceito, sendo que generalização e significado da palavra são sinônimos: "Toda generalização, toda formação de conceitos é o ato mais específico, mais autêntico e mais indiscutível de pensamento" (VIGOTSKI, 2001, p 110). 
Vigotski (2001) explicita ainda que o significado da palavra só pode ser interpretado como um fenômeno de pensamento na medida em que o pensamento está relacionado à palavra e nela materializado. $O$ processo contrário também é válido (VIGOTSKI, 2001).

Essa associação que relaciona a palavra ao significado pode ser reforçada ou debilitada. A depender de uma série de vínculos com outros objetos da mesma condição, pode estender-se a uma gama maior de objetos ou restringir-se a um grupo específico (VIGOTSKI, 2001). De acordo com o autor (VIGOTSKI, 2001, p. 114): "A palavra nos infunde a lembrança do seu significado como qualquer coisa nos faz lembrar outra coisa".

Ainda a respeito dos significados das palavras, o autor afirma:

No processo do desenvolvimento histórico da língua, modifica-se a
estrutura semântica dos significados das palavras e a natureza
psicológica desses significados, a ignorar que o pensamento
linguístico passa das formas inferiores e primitivas de generalização a
formas superiores e mais complexas, que encontram expressões nos
conceitos abstratos, e, finalmente, que no curso do desenvolvimento
histórico da palavra, modificam-se tanto o conteúdo concreto da
palavra quanto o próprio caráter da representação e da generalização
da realidade na palavra (VIGOTSKI, 2001, p.114).

Tal processo inicia seu desenvolvimento na idade infantil, assim também a definição dos estágios básicos de desenvolvimento desses significados, mas, para que seja possível a compreensão de uma palavra, é necessário compreender o conceito que ela representa (RESENDE, 2014).

A comunicação se limita quando há ausência de um sistema de signos, sendo este signo uma palavra ou som que, pela ocorrência simultânea, associa-se ao conteúdo relacionado às experiências do indivíduo que, por sua vez, pode transmitir esses mesmos conteúdos a outros (VIGOTSKI, 1993). Nesse processo, a comunicação é estabelecida. Como afirma o autor: "(...) a experiência pessoal habita exclusivamente a própria consciência do indivíduo e não é transmissível, estritamente falando" (VIGOTSKI, 1993, p.13). Nessa citação do autor, pode-se incluir falas orais ou sinalizadas, pois ambas passam pelo mesmo processo de comunicação.

A linguagem origina-se como meio de comunicação entre a criança e as pessoas que estão à sua volta, porém, somente depois é convertida em linguagem interna, transformando-se em função mental interna fornecendo, 
assim, meios fundamentais ao pensamento do sujeito nas fases iniciais de seu desenvolvimento (VIGOTSKI, 2001).

Como um exemplo, Resende (2014) expõe que, no âmbito escolar, o processo de comunicação ocorre por meio do uso induzido de palavras representativas a partir de conceitos e, no decorrer do desenvolvimento de atividades, essas palavras passam a ter maior significado através da busca de solução para um dado problema. O uso da palavra serve para orientar a formação de conceitos e, consequentemente, permite ao aluno reorganizar sua estrutura cognitiva pela possibilidade de ser trabalhada em diferentes contextos de significado, sempre dentro do processo de ensino. (RESENDE, 2014).

No caso dos alunos Surdos, não há essa palavra, já que em algumas vezes há um sinal específico e em outras vezes o conceito é representado pelos classificadores, no entanto, esses elementos permitem a formação de conceitos.

As expressões fonéticas são formas de exprimir as palavras estabelecendo, assim, uma comunicação entre pares. Vigotski cita Koehler em um estudo com chimpanzés nas Ilhas Canárias para descrever as expressões fonéticas em outros animais (VIGOTSKI, 1993 apud KOEHLER, 1921). Esse estudo menciona que as expressões fonéticas dos chimpanzés indicam desejos e subjetividades, mas suas comunicações linguísticas ocorrem através de jogos faciais, gestos, vocalização, movimentos expressando saudações e emoções, tornando-os, dessa maneira, capazes de se comunicar e, consequentemente, de se compreender mutuamente (VIGOTSKI, 1993 apud KOEHLER, 1921).

Tendo como base a língua oral, o fonema, termo que quer dizer "a menor unidade fonética indivisível pertinente para o significado" (VIGOTSKI, 1993, p. 47), é uma forte característica da linguagem humana, diferenciando-se de outros sons que podemos emitir.

Afirma no trecho destacado:

A linguagem não depende necessariamente do som. Há, por exemplo, a linguagem dos Surdos-mudos e a leitura dos lábios, que é também interpretação de movimentos.(...) Em princípio, a linguagem não depende da natureza material que utiliza. (...) Não importa qual o meio, mas sim o uso funcional dos signos, de quaisquer signos que pudessem exercer um papel correspondente ao da fala nos homens (VIGOTSKI, 1993, p. 47). 


\subsubsection{Do conhecimento à formação de conceitos científicos}

De acordo com a teoria histórico-cultural de Vigotski, os conhecimentos se constituem a partir da interação social das pessoas. Assim, a aprendizagem é um processo social e o conhecimento é algo socialmente construído, uma vez que o sujeito é um ser interativo nas ações e no processo de aprendizagem (RESENDE, 2014).

Davidov (1978) aponta que o essencial não consiste em demonstrar a essência dos conhecimentos passados em geral, e sim: “(...) a observação da necessidade de correspondência entre as noções escolares e o conteúdo da experiência dos alunos" (p. 103). Cabe ressaltar que a experiência "individual" trazida pelos alunos integra as representações empiricamente formadas deles mesmos sobre seu entorno (DAVIDOV, 1978).

$\mathrm{O}$ autor afirma que a experiência deve ser utilizada no ensino, com a condição de ser "mediante uma reestruturação substancial dentro da forma de conhecimento científico, qualitativamente singular e nova para o aluno, e que em modo algum harmoniza e nem pode harmonizar com a simples experiência vital" (DAVIDOV, 1978, p. 103 - grifos do autor). As noções habituais trazidas pelos alunos devem ser inseridas no ensino, mas com condições gerais e não específicas, pelo conteúdo e forma dos conhecimentos científicos (DAVIDOV, 1978).

O conhecimento que se converte em conceito, consiste em um "método para refletir o desenvolvimento do objeto a partir de certa base genética, como dedução do diverso dentro do todo, como realização da unidade, da identidade e das diferenças" (DAVIDOV, 1978, p. 267).

O desenvolvimento humano ocorre por meio da interação social e cultural que permeia a vida de todos os sujeitos, sob uma perspectiva sóciointeracionista (RESENDE, 2014).

Os processos mentais superiores se desenvolvem ao longo do desenvolvimento do indivíduo, sendo este resultado da interação com o mundo em que vive, sempre considerando os aspectos sócio-históricos construídos (RESENDE, 2014). Para o indivíduo interagir com o mundo, ele utiliza 
elementos mediadores e, assim, Vigotski (2001) ressalta que é na relação mediada do homem com o mundo que se desenvolvem suas funções psicológicas (RESENDE, 2014). Com isso, em um certo ponto do desenvolvimento humano, essas mediações passam a predominar sobre relações diretas e reflexivas, sendo essas ações mediadas por instrumentos e signos (RESENDE, 2014).

Os instrumentos físico e material são considerados ferramentas que permitem a concretização da ação do homem sobre a natureza, já os signos simbólicos são meios usados para solucionar um problema, assumindo uma dimensão psicológica, sendo estes elementos situados em um contexto histórico que os define como mutáveis (RESENDE, 2014).

De acordo com Resende (2014, p.18), "as ferramentas e sistemas de signos facilitam a concretização de uma ação sobre o mundo na resolução de uma dada situação problema". A autora define "ferramentas" e "signos" de forma mais especificada no trecho a seguir:

(...) a ferramenta, definida como instrumento, é um objeto concreto produzido pelo homem para ações específicas, utilizada para solução de situações problemas buscando ampliar as possibilidades de transformação sobre mundo [sic], ou seja, é mais fácil caçar com uma arma do que com as mãos nuas. Dessa forma, o instrumento tem função diretiva para um fim específico e o seu resguardo para utilizações posteriores preserva sua função. A transmissão a outros indivíduos dentro de um contexto social torna esse instrumento uma característica tipicamente humana (RESENDE, 2014, p.18).

Nas obras de Vigotski, especificamente em A construção do pensamento e da linguagem (2001), o autor afirma que a operação das funções mentais ocorre por meio dos signos, sendo estes construídos ao longo do desenvolvimento humano. Ferramentas e signos podem variar em função do contexto sócio-cultural e do desenvolvimento do indivíduo (RESENDE, 2014).

No processo da formação do sujeito e da internalização sócio-cultural, os contextos históricos, culturais, sociais e de linguagem fazem parte da aprendizagem (RESENDE, 2014). De acordo com Vigotski (2001), esses fatores em interações com indivíduos de um dado grupo, somados a um caráter mediador, como exemplo, um professor de uma escola que utiliza instrumentos de ensino, podem auxiliar o aluno a executar tarefas e, se 
realmente houver aprendizagem, posteriormente, esse aluno realizará tais tarefas sozinho.

Caso ocorra uma privação de linguagem, isso interfere diretamente em seu processo de aprendizagem. Se o aluno Surdo está inserido em um contexto escolar em que não há outros indivíduos com os quais possa se comunicar plenamente, uma vez que, além de os ouvintes não falarem Libras, eles não compartilham aspectos históricos, sociais e culturais relativos à cultura Surda, isso pode ser bastante negativo para o seu desenvolvimento. Essas diferenças culturais e linguísticas podem constituir uma barreira ainda maior se o professor priorizar instrumentos de ensino que favoreçam apenas os alunos ouvintes, levando o aluno Surdo a uma estagnação no processo de aprendizagem e a um isolamento.

Os conceitos definidos por Resende (2014) como "elementos de uma abstração que permite definir a relação de um conjunto de objetos concretos com uma formação mental", quando também mediados por instrumentos, signos ou palavras, podem ser orientados para a resolução de um determinado problema. Nesse processo de formação de conceitos, tais não surgirão por um acaso, mas perante situações postas permitindo sua significação (RESENDE, 2014, p. 22).

Davidov (1978, p.55) destaca que a lógica de formação de conceitos segue o seguinte padrão: "percepção - representação - conceito". As representações se expressam para o indivíduo com a percepção de imagens vivas de objetos resgatados por suas memórias, podendo tornar-se fonte de conceitos. Afirma o autor que "o trânsito da percepção ao conceito equivale ao trânsito sensorial, concreto e singular ao mental, abstrato e geral" (DAVIDOV, 1978, p. 55). O autor ressalta ainda que os elementos primordiais constitutivos dos conceitos são: existência de recursos essenciais, permitindo a distinção de uma classe de objetos das demais; a expressão verbalizada do significado e, como último elemento, destaca que pode ter um caráter abstrato, inconcreto, não necessariamente relacionado à presença de imagens diretas.

Os conceitos, sendo "transmitidos" de forma passiva e direta, são vazios de significado ao aluno. É possível que pareça que, dessa forma, estão comunicando um conhecimento, mas, na realidade, essa questão somente encobre um vácuo (VIGOTSKI, 1993). Ao ter o contato com uma palavra 
desconhecida em uma frase e, posteriormente, encontrá-la em outro contexto, o estudante pode vir a ter uma vaga ideia do novo conceito que, em algum momento, será necessário utilizar (VIGOTSKI, 1993).

A mesma afirmação cabe para os sinais da Libras. A princípio, um novo sinal pode causar estranhamento ao aluno Surdo, mas com o uso, pouco a pouco o aluno vai agregando o sinal ao seu vocabulário. Caso o sinal já exista em outros contextos e seja utilizado também para representar um conceito científico, é necessário haver uma boa diferenciação dos possíveis significados que aquele sinal carrega para que o aluno não confunda seu uso e possa incorporar aquele conceito nos diferentes contextos.

Vigotski (2001) ressalta que situações de vivências escolares permitem melhor sistematização dos conceitos abordados porque consentem a evolução dos conceitos para níveis superiores no processo mental do indivíduo. Já a produção de novos modos de pensamento, em comparação ao que o aluno possuía antes, surge de novos movimentos mentais pela necessidade de se dominar concepções para descrever fenômenos, permitindo a elaboração de concepções de mundo por parte do indivíduo (RESENDE, 2014).

Em resumo, a formação de conceito (ou a construção de sentido) através da palavra é o resultado de uma atividade intensa e complexa (operação com palavra ou signo), da qual todas as funções intelectuais básicas participam em uma combinação original. $O$ mesmo processo pode ser comparado também com a língua de sinais, mas, ao invés de palavras, os sinais assumem essa função.

A associação, a atenção, o juízo e a representação (que colaboram mutuamente), participam da formação de conceitos, mas nenhum deles é o processo determinante e essencial que pode explicar o surgimento de uma nova forma de pensamento qualitativamente original e irredutível a outras operações intelectuais elementares, embora todas essas funções sejam participantes obrigatórias da síntese complexa que, em realidade, é o processo de formação de conceitos. Consequentemente, nenhum deles pode ser considerado fator genético essencialmente determinante no desenvolvimento dos conceitos. O conceito é impossível sem palavras, o pensamento em conceitos é impossível fora do pensamento verbal (VIGOTSKI, 2001). 
Estendemos o que o autor diz sobre "palavras" para os "sinais", já que, sem sinais, o aluno Surdo não chega à formação de um conceito. $O$ pensamento verbal de um Surdo é feito com sinais, eles pensam em sinais e a partir desse pensamento os conceitos são formados.

Os conceitos cotidianos e científicos se diferem. Conceitos cotidianos são fundamentados pela interação dos sujeitos a partir do meio em que vivem, já os conceitos científicos fazem parte do contexto formal de ensino (RESENDE, 2014). De acordo com Rosa (2010), diferem-se também na evolução desses conceitos, sendo os conceitos cotidianos desenvolvidos de forma vertical, para um nível de abstração mais elevado, e os conceitos científicos para um nível mais concreto do conceito por possibilitar que o indivíduo alcance novos níveis de desenvolvimento (RESENDE, 2014).

A consciência reflexiva nos alunos é possível através das portas que se abrem no processo de desenvolvimento dos conceitos científicos, sendo a instrução escolar fundamental para induzir o tipo de percepção generalizante, cumprindo um papel importante na conscientização do processo mental do estudante (VIGOTSKI, 1993). Na concepção de Vigotski (2001), os conceitos científicos, com o seu "sistema hierárquico de inter-relações", são um meio de "desenvolvimento da consciência e domínio do objeto", posteriormente transmitidos para outros conceitos e outras áreas do pensamento.

No contexto das aulas de ciências, muitos dos conhecimentos formais transmitidos a um aluno podem não ser experienciados por ele. Nisso, os conceitos científicos e os conceitos espontâneos diferem-se pela relação que constituem através da experiência do estudante (VIGOTSKI, 1993).

Os conceitos científicos, que são conceitos reais, são formados de maneira semelhante aos conceitos artificiais ou cotidianos. Para que seja possível desenvolver uma medição, é necessário conhecer e acompanhar as principais características dos conceitos cotidianos desde a idade escolar e a direção que será dada ao seu desenvolvimento durante esse período (VIGOTSKI, 1993).

Ainda a respeito dos conceitos científicos, o autor afirma:

Embora os conceitos não sejam absorvidos já completamente formados, a instrução e a aprendizagem desempenham um papel predominante na sua aquisição. Descobrir a relação complexa entre a 
instrução e o desenvolvimento dos conceitos científicos é uma importante tarefa prática (VIGOTSKI, 1993).

O autor afirma que: "(...) a evolução dos conceitos científicos não nega a existência de um processo de desenvolvimento no cérebro da criança em idade escolar (...)" (VIGOTSKI, 1993, p. 85). Mas Vigotski deixa claro que essa questão não é diferente das maneiras através das quais os conceitos são formados no indivíduo cotidianamente, espontâneos e não espontâneos, contrapondo a ideia de que o que é novo no desenvolvimento provém do exterior, através da substituição dos modos de pensamento próprios do sujeito.

Uma ideia que agrega a esse pensamento é a noção de perfil conceitual, descrita em Mortimer (1994, 1995, 2000). Essa reflexão traz que: "um único conceito pode ter diferentes zonas que correspondem a diferentes maneiras de ver, representar e significar o mundo, e são usadas pelas pessoas em contextos diferenciados" (COUTINHO; MORTIMER; EL-HANI, 2007, p. 116). De acordo com essa ideia, as pessoas podem compreender um mesmo conceito de distintas maneiras.

A partir disso, o ensino de Ciências pode trazer um enriquecimento dos perfis conceituais de cada aluno, acompanhado por uma "demarcação clara dos domínios de aplicação de cada modo de pensar e de falar" (COUTINHO; MORTIMER; EL-HANI, 2007, p. 116).

Não há uma regra única para se trabalhar o ensino-aprendizagem de acordo com as áreas científicas porque, para cada conceito abordado, há uma diversidade de estratégias para entender cada perfil, sendo o ensinoaprendizagem correspondente da carga de significados que carrega cada conceito (COUTINHO; MORTIMER; EL-HANI, 2007).

A respeito dos conceitos científicos, Vigotski (1993) considera defasado o argumento de que os conceitos científicos não sofrem desenvolvimento e são absorvidos através apenas da compreensão e assimilação. Afirma que a definição do que é um conceito não se limita à soma de ligações realizadas pela memória, de modo que ele os define como: “(...) um complexo e genuíno ato de pensamento, que não pode ser ensinado pelo constante repisar, antes, pelo contrário, que só pode ser realizado quando o próprio desenvolvimento mental da criança tiver atingido o nível necessário." (VIGOTSKI, 1993, p.83). 
De acordo com Ivic (2010), o processo de aquisição dos sistemas de conceitos científicos pode ser comparado ao processo de aquisição da linguagem no quadro da educação sistemática de tipo escolar. Para o autor, a aprendizagem possui um papel construtor, mas requer a presença de adultos como parceiros nas atividades comuns e não somente adultos que dominem a língua (IVIC, 2010).

A presença dos adultos como pessoas mediadoras das atividades escolares é necessária tanto para ouvintes quanto para Surdos. No ensino de Surdos, o contexto atual nas escolas bilíngues aponta para uma maioria de professores ouvintes, que legalmente devem dominar a língua de sinais. No entanto, é fundamental para o desenvolvimento cognitivo do aluno Surdo a presença de adultos Surdos nos espações escolares porque, apesar de os professores ouvintes "dominarem" a língua de sinais para ministrarem as aulas, esta não é sua língua materna. Os adultos Surdos, com função de instrutores nesses espaços escolares, são fundamentais para a aquisição de língua desses alunos e para o desenvolvimento de sua aprendizagem.

Para Ivic (2010), a aquisição dos sistemas de conceitos científicos é a aquisição mais importante ao longo do período escolar. Conforme esse autor nos lembra, para Vigotski, o sistema de conceitos científicos é um instrumento cultural que porta mensagens intensas e, ao assimilá-lo, permite ao sujeito mudar seu modo de pensar profundamente (IVIC, 2010). Os conceitos científicos são estruturados pela organização em sistemas hierarquizados, podendo ser através de redes, grupos, árvores genealógicas, entre outros. Com essas estruturas interiorizadas, o indivíduo pode ampliar as possibilidades de seu pensamento, mas tal estrutura deve colocar à disposição um conjunto de operações intelectuais (IVIC, 2010).

O processo de generalização pode ser representado em um conceito encarnado numa palavra, sendo esta uma generalização do tipo primitiva, porém, o significado dessa palavra se desenvolve e evolui sendo substituído por generalizações mais elevadas, tendo como resultado a formação de conceitos (VIGOTSKI, 2001). Para Davidov (1978, p. 55), o processo generalizador consiste em "encontrar o comum dado e formar a classe como portadora dela mesma". De acordo com as concepções de Vigotski (1993, p.84), o desenvolvimento dos conceitos e dos significados das palavras implica 
também no desenvolvimento de "(...) atenção deliberada, memória lógica, abstração, capacidade para comparar e diferenciar."

Contudo, das palavras ou sinais à formação de conceitos e, posteriormente, ao desenvolvimento de outras funções mentais como as citadas (atenção deliberada, memória lógica, abstração e capacidade de comparação e diferenciação), ocorrem processos cognitivos e mentais complexos que partem de simples palavras ou sinais, quando bem aplicadas e contextualizadas. No ensino de Surdos, os sinais científicos ainda não estão plenamente constituídos. Como então os alunos passarão por todo esse processo cognitivo? Estão passando por isso ou não? Essa análise será feita e discutida nos próximos capítulos, com a apresentação dos resultados do que foi observado em aula.

\subsubsection{Defectologia e a visão da surdez}

A obra de Vigotski, Fundamentos de defectologia (1997), considera a interação social dos indivíduos com deficiência, mas explicita que "as barreiras impostas para o desenvolvimento cognitivo desse indivíduo são mais sociais do que biológicas, quando esses são marginalizados" (RESENDE, 2014).

Em um de seus capítulos, o autor revela as principais ideias sobre a educação de Surdos e faz uma crítica quanto à forma com que se aplicava o denominado "método oral puro" (desenvolvido na Alemanha). Ele considera que a educação acabava recorrendo a uma repressão sobre a criança por ter como objetivo principal ensinar-Ihe a linguagem oral, desconsiderando o interesse próprio da criança (ALBRES, 2005). Mesmo assim, defende a leitura do movimento dos lábios como vantajosa, por possibilitar a comunicação do Surdo com ouvintes e como "instrumento de elaboração do pensamento e da consciência" (VISGOTSKI, 1997, p. 63).

$\mathrm{Na}$ obra, Vigotski declara a "linguagem gestual" como natural dos Surdos, sendo pobre, limitada e primitiva por prender o Surdo a um 
"microcosmo restrito" aos indivíduos que têm o conhecimento dessa língua (VISGOTSKI, 1997).

De acordo com Albres (2005), Vigotski (1997) opõe-se ao "método analítico de ensino de sons separados" porque deveria ser usada uma frase inteira à qual a "mímica" estaria subordinada. Dessa maneira, o que se chamava de "linguagem sistemática dos sinais" foi colocada em desmerecimento pelo meio científico, pois acreditava-se não surgir da experiência social e, nesta concepção, "(...) se desenvolve a consciência e o pensamento" (ALBRES, 2005, p. 24).

A respeito da educação de Surdos, Vigotski (1997) afirma que:

\begin{abstract}
Até o presente não temos um sistema cientificamente elaborado e competente nem em forma de teoria pedagógica de educação da criança Surda, nem em forma de teoria psicológica de seu desenvolvimento evolutivo e das particularidades físicas vinculadas ao problema no ouvido e déficit social, quero dizer, a ausência da linguagem oral (VISGOTSKI, 1997, p. 115).
\end{abstract}

A partir do trecho ressaltado acima, Albres (2005) afirma que Vigotski discute procedimentos de diferentes métodos de pronunciação, revisando todos os sistemas já existentes, concluindo que, por si só, nenhum método poderia resolver os problemas de desenvolvimento da linguagem oral nos estudantes Surdos, não encontrando solução para essa questão.

Tal busca continua até os dias atuais e as diferentes abordagens educacionais continuam em estudo. Na época em que as obras de Vigotski foram produzidas, a insatisfação tomava os pedagogos e pesquisadores, mas Vigotski (1928/1997) afirmava que, com o método com o qual trabalhavam, a educação social não se realizaria sem linguagem, este trabalho seria impossível, e as denominadas "linguagens oral e mímica" que a escola proporcionava aos alunos eram consideradas uma "linguagem não social" (ALBRES, 2005). De acordo com Albres (2005), Vigotski relata em sua obra (1997) que procurava uma técnica que proporcionasse a língua oral, se posicionando contra o ensino fonético e contra o que chamava de "mímica", organizando uma escola experimental associada a centros docentes superiores. 
Em um determinado trecho da obra, Vigotski se opõe ao oralismo, reconhecendo que este não é um meio de comunicação eficiente aos Surdos e que também não thes garante a linguagem $e$, consequentemente, 0 pensamento:

Os Surdomudos falam com ajuda da mímica; a linguagem oral é algo alheio a eles. Praticamente não os beneficia a nada, quase não ajuda seu desenvolvimento e formação, nem constitui um instrumento de acumulação da experiência social e de participação na vida social (VIGOTSKI, 1997, p. 342).

No ano de 1930, relata suas impressões sobre o "desenvolvimento lingüístico das crianças Surdas", afirmando, enfim, que é necessário para a criança Surda a "mímica" e a linguagem escrita como forma efetiva à sua comunicação (ALBRES, 2005). Afirma, de igual modo, que o estímulo oral é ineficaz na educação de Surdos, conforme o trecho destacado a seguir:

Ademais, a língua oral contradiz os princípios fundamentais da psicologia da linguagem. Tenta formar uma palavra a partir dos sons e uma frase a partir de palavras. Assim, tanto desde esse ponto de vista social, estéril e para a prática na vida, quase inútil (VIGOTSKI, 1997, p. 342).

Com isso, no trecho a seguir, Vigotski (1997) ressalta os princípios que norteiam seus estudos para um desenvolvimento eficaz da linguagem nos Surdos:

\begin{abstract}
A luta pela frase inteira, pela palavra - contra a preparação fonética da linguagem, a luta da unidade da linguagem oral - contra o jargão da mímica; a luta pela estimulação natural do desenvolvimento, da linguagem tirado da vida - contra sua assimilação ineficaz nas lições, essa é a orientação da nossa busca (VIGOTSKI, 1997, p. 343).
\end{abstract}

Albres (2005), em citação a Lacerda e Monteiro (2002), menciona que tais indicações de Vigotski revelam uma concordância a respeito das abordagens de comunicação total ou do bilinguismo ao propor uma educação "diglóssica". O autor afirma: "[a] escola determina o sistema, e não o contrário (VIGOTSKI, 1997, p. 342)", sendo a escola algo fundamental para propor uma abordagem diferenciada para o ensino de Surdos na época, e não somente se submeter à abordagem oralista sem nenhum estudo crítico. 
Vigotski, por ser um estudioso da consciência a partir da linguagem, pode ter encontrado outras formas de manifestação da capacidade linguística nos Surdos. Entretanto, o foco que se propôs a abordar em sua obra não dá elementos para a elaboração de propostas de educação de Surdos (ALBRES, 2005). Mesmo assim, indica que a aquisição da linguagem do Surdo ocorre diferentemente do ouvinte, e que isto seria o fundamento principal para trabalhar com o que até hoje as escolas têm dificuldade em trabalhar: diferenças linguísticas:

\begin{abstract}
A linguagem surgirá na criança Surda-muda quando for necessário, quando estiver ao serviço de toda prática e de toda sua vida e não reformar o método. A base imprescindível para resolver o problema da linguagem é uma educação social amplamente desenvolvida. (VIGOTSKI, 1997, p. 342).
\end{abstract}

A partir das reflexões apresentadas nessa obra (VIGOTSKI, 1997), a inclusão das pessoas com deficiência, dentro de um contexto social comum, permite que os indivíduos Surdos desenvolvam melhor suas funções mentais, combinados a modos suplementares de comunicação como uma forma de mediação que auxilia no desenvolvimento das atividades (RESENDE, 2014). Por sua vez, a linguagem é "mediadora da organização cognitiva do sujeito", permitindo, assim, que o pensamento se desenvolva, resultando no processo de aprendizagem (RESENDE, 2014). 


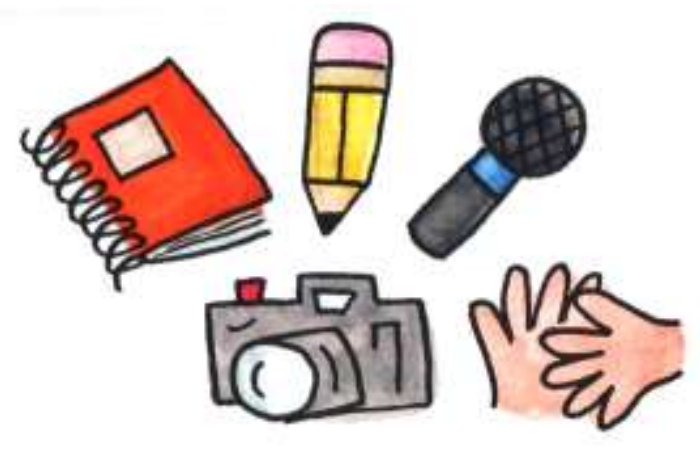

\section{Procedimentos Metodológicos}

Para o andamento da pesquisa, a coleta de dados da pesquisa foi dividida em cinco tipos de registros. São eles:

A) Observação das aulas: as aulas de ciências em uma escola bilíngue para Surdos foram acompanhadas presencialmente no período do segundo semestre do ano de 2014 e registradas através de vídeos e diário de campo, com o intuito de verificar como o professor utiliza os sinais quando se refere a termos científicos no contexto bilíngue.

B) Diário de Campo: utilizado para o registro de observações realizadas em campo e das ideias que surgiram durante a observação. $O$ registro foi feito de forma bem descritiva para o material ficar bem completo, facilitando as análises posteriores. Tal forma de registro é característica de uma pesquisa etnográfica. O pesquisador aproxima-se das pessoas, situações, locais, eventos, mantendo com eles um contato direto e prolongado, sem a pretensão de mudar o ambiente, e sim de participar e observados sua manifestação natural (ANDRÉ, 2008). O diário de campo permite registro da observação detalhada, possibilitando ao leitor a sensação de estar no referido evento.

C) Entrevista: foi realizada uma entrevista com o professor de ciências para verificar qual é a posição dele no que se refere ao seu trabalho com diversas línguas e linguagens que ocorrem concomitantemente durante as aulas de biologia. 
D) Registro em vídeos: foram obtidos vídeos que o professor da turma filmou com a finalidade de avaliar os alunos ao final do desenvolvimento de conteúdos de biologia. Além disso, foi solicitada a autorização (Apêndice 01) dos responsáveis para a realização de imagens.

Dentre as vantagens da filmagem, destaca-se que ela não se limita à descrição de fenômenos, e sim aos modos como esses fenômenos são vividos e representados pelos sujeitos envolvidos no processo. A busca de informação deve ser permanentemente monitorada pelo referencial teórico que incorpora questões da "cultura" e do "cotidiano" e, por fim, é necessário que tais conceitos, já assumidos teoricamente, manifestem-se na prática cotidiana da pesquisa (TOSTA et al., s.d., p. 7). Com esse recurso, é possível retratar situações da vida real, sem prejuízo da dinâmica natural.

Depois foi realizada uma análise de termos científicos a partir de um levantamento acerca dos que surgiram durante o desenvolvimento dos conteúdos nas aulas observadas, foi realizada uma consulta nos principais dicionários bilíngues de Libras e português, verificando se existem sinais para os termos.

Esse método de análise qualitativa é denominado de triangulação (MARCONDES \& BRISOLA, 2014). Toma-se três tipos de dados como base para uma validação mais eficiente das análises, aproximando, assim, o resultado com o real. No caso, esta pesquisa levou em consideração as dimensões do diário de campo, entrevista com o professor e avaliação dos alunos, contextualizando os dados com pesquisas bibliográficas. 


\subsection{Caracterização do ambiente de pesquisa}

Para este estudo, o campo de pesquisa se restringiu a uma escola pública municipal composta prioritariamente por alunos Surdos, caracterizada como escola bilíngue. Foram acompanhadas semanalmente as aulas de Ciências de uma turma de sétimo ano do Ciclo II durante o segundo semestre de 2014.

A sala em que se fez o acompanhamento de aulas, assim como nas escolas comuns, possui carteiras, mesa do professor e um quadro branco. Mas, nessa escola, alguns aspectos se diferenciam, tais como o sinal que indica os horários de troca de aula e intervalos que, além de sonoro, é luminoso, e o tamanho das salas que são bem menores, com capacidade para, no máximo, doze carteiras, pois a comunicação exige que todos possam fazer contato visual mutuamente.

A turma acompanhada foi a do sétimo ano do Ensino Fundamental II, com dez alunos em sala, sendo seis meninos e quatro meninas. Dentre os estudantes, destaca-se que dois deles possuem surdez moderada, possibilitando-Ihes distinção entre sons, mas somente um entre os dois era oralizado. O outro, mesmo ouvindo parcialmente, priorizava a Libras e não emitia sons em sua comunicação. Uma das estudantes tinha apenas um conhecimento básico da Libras, não conseguia se expressar bem em relação aos outros colegas e, por conta disso, manifestava uma grande dificuldade de compreensão das aulas. Um estudante possui deficiência motora afetando todo o corpo e, principalmente, o movimento das mãos, que é impreciso ao se comunicar em Libras. No entanto, ele demonstrou, durante as aulas, que estava compreendendo os conteúdos.

O Professor de ciências é Biólogo, se comunica com os alunos em Libras e se mostra sempre preocupado no aprendizado dos alunos, por isso sempre faz um bom planejamento de suas aulas utilizando diversas abordagens metodológicas em aula. A trajetória do professor até trabalhar com Surdos está descrita na primeira questão da entrevista (Apêndice 2). 
Para uma melhor visualização dos alunos e do professor, a localização da pesquisadora na sala de aula ocorria de acordo com a imagem abaixo (Figura 13). É necessário que o observador em uma sala de Surdos ocupe uma posição que the permita observar a comunicação e expressão facial dos estudantes em língua de sinais, e também do professor (que durante a aula, se posicionava frente a sala deslocando-se para melhor visualizar os alunos):

Figura 13: Disposição da pesquisadora na sala de aula durante toda a coleta de dados

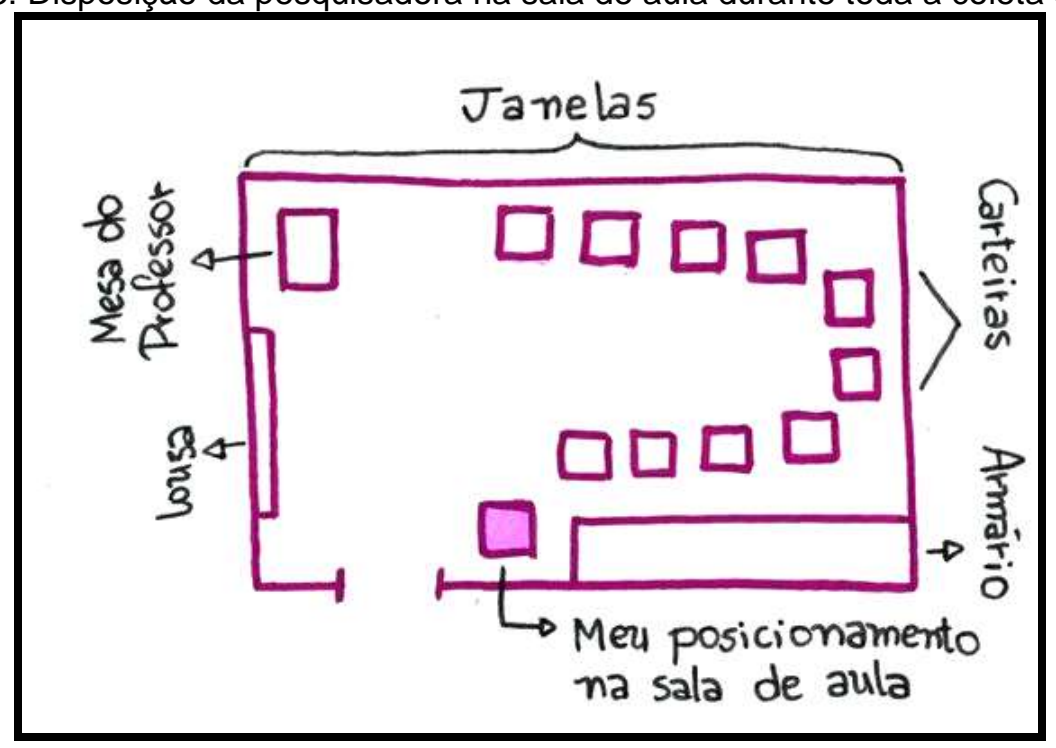

Fonte: Elaborada pela pesquisadora Beatriz Crittelli

\subsection{Forma de análise dos resultados}

Para a presente pesquisa, foi adotada a abordagem qualitativa, que se baseia na análise dos microprocessos (MARTINS, 2004). Para analisar os fenômenos descritos, será realizado um estudo de caso que possibilita uma visão profunda, ampla e integrada de uma unidade social complexa, além de permitir retratar situações de vida real sem prejuízo de sua complexidade e sua dinâmica natural (ANDRÉ, 2005).

A configuração de estudo de caso se dá por conta do contexto de pesquisa estudado, um cenário específico que se resume em uma escola que trabalha com português e Libras com o público constituído exclusivamente por alunos Surdos, em um determinado período de uma série específica. 
De acordo com abordagem etnográfica de pesquisa, um dos meios mais adequados de análise é a descrição completa e literal do fenômeno a ser analisado e, juntamente, interpretação das variáveis que compõem tal fenômeno contemporâneo que ocorre na vida real. Por isso, optou-se por fazer a descrição dos resultados em primeira pessoa.

O pesquisador que se dispõe a seguir em seu trabalho uma abordagem etnográfica fica diante de um cenário que pode apresentar diferentes formas de interpretação da vida, diferentes formas de compreensão do senso comum, diferentes significados atribuídos pelos participantes às suas experiências e vivências. Assim, a partir do cenário em que contextualiza sua pesquisa, propõe-se a mostrar esses múltiplos significados ao leitor (ANDRÉ, 2008).

André (2008) afirma que, de acordo com os antropólogos, a etnografia significa "descrição cultural" a partir de um conjunto de técnicas que o próprio pesquisador utiliza para coletar dados sobre valores, hábitos, crenças, práticas e comportamento de um grupo social, podendo-se também definir como um relato escrito resultante do emprego dessas técnicas.

Uma característica importante da pesquisa etnográfica é a ênfase no processo, naquilo que está ocorrendo, e não nos resultados finais. Assim, o pesquisador possui uma preocupação com o significado, com a maneira particular das pessoas enxergarem a si mesmas, as suas experiências e o mundo que as cercam, sendo tarefa do pesquisador tentar, a todo o momento, apreender e retratar essa visão pessoal dos participantes (ANDRÉ, 2008).

Através das análises dos termos científicos utilizados nas aulas de Ciências, foi realizado um levantamento a partir das observações realizadas em aula. Todos os dados foram organizados e divididos em quadros com os tópicos dos principais conteúdos abordados nas aulas observadas; principais termos científicos relacionados; verificação de tais termos em dicionários bilíngues (Libras e português) e apropriação correta dos termos.

Para uma análise sistemática dos dados, os materiais foram organizados a partir dos conteúdos da área de Biologia abordados nas aulas analisadas. Posteriormente, foi realizada uma leitura e releitura do material, identificando pontos importantes e construindo categorias descritivas para adequar aos quadros ou tabelas. Sempre que necessário, foram consultadas as descrições anotadas no diário de campo e vídeos das atividades avaliativas. Foi feita uma 
análise confrontando os dados encontrados com a literatura e com outros estudos, produzindo novos conhecimentos sobre o assunto.

Para uma melhor compreensão do leitor, os termos científicos trabalhados em aula serão escritos em itálico até o final do trabalho, e as palavras correspondentes a sinais da Libras serão escritas em caixa alta.

O conhecimento de um caso em profundidade pode ajudar a entender outros eventos. No caso, a ideia de generalização é aceita no sentido de que os dados de um estudo possam ser úteis para compreender dados de outros estudos (ANDRÉ, 2005). 


\section{ANÁLISE DE RESULTADOS}

\subsection{Descrição da sequência de aulas}

Com a finalidade de facilitar o entendimento da análise dos resultados, neste tópico, descreverei como se desenvolveu a sequência de aulas que acompanhei, desde seu planejamento, execução, até as avaliações finais.

No caso, o Professor ressaltou na entrevista:

Eu sempre penso com o que eles já podem fazer sozinhos, né? Com o que eles já podem fazer com uma certa autonomia, porque se eu pensar que eles podem fazer com autonomia, eu consigo partir do que eles já sabem fazer e ir para algum outro lugar (...) (transcrição literal da entrevista com o Professor de ciências).

O Professor indicou, em sua fala, que inicia as discussões de suas aulas pelos conhecimentos prévios dos alunos, mas o tema e estratégias de aula são planejados com antecedência.

Ao longo do semestre, a organização das aulas seguiu a seguinte sequência: 
- Imagens e vídeos apresentados aos alunos com o questionamento: "o que está acontecendo com esses seres vivos?"

- A partir das imagens e vídeos, os alunos elaboram hipóteses.

- Combinam-se sinais em Libras para os conceitos levantados

- Elaboração de frases correspondente aos conceitos levantados (formuladas também em tabelas).

- Cada aluno fazia três desenhos de animais, cada um correspondente às adaptações defensivas estudadas.

- Realizaram uma atividade no pátio da escola com os animais desenhados, posicionando-os no ambiente a fim de simular suas adaptações defensivas na natureza.

- Pegaram novamente os animais desenhados do pátio, colaram na lousa e montaram uma teia alimentar.

- Os desenhos foram retirados e no lugar, escreveram os nomes dos animais.

- Formação de frases a partir dos esquemas de teia alimentar da lousa.

- Os alunos junto do professor estipularam critérios para a avaliação.

- As avaliações foram realizadas em sala, registradas em vídeo com a lousa escrita e avaliando os alunos em Libras.

A seguir, cada ponto apresentado será explicado de acordo com as observações registradas no diário de campo.

Em sala de aula, o Professor levou imagens e vídeos relacionados ao tema. A sequência se iniciou com o tema interações ecológicas dos seres vivos no ambiente. O Professor levou slides com diversas imagens de seres vivos, agrupadas pelos tipos de interação que esses seres realizavam no ambiente, porém, sem nenhum indicativo escrito. Com isso, questionava os alunos quanto ao que estava ocorrendo com esses seres, os motivos de estarem realizando aquelas ações ou mesmo as características relacionadas aos seus próprios aspectos físicos.

A partir dos questionamentos, observação e análise das imagens, os alunos elaboraram três hipóteses principais: um grupo de seres vivos está se escondendo no ambiente; um grupo de seres vivos está imitando o ambiente 
com suas características físicas; e outro grupo de seres vivos indica perigo através de sua coloração.

Com as hipóteses elaboradas, o Professor começa a introduzir os conceitos científicos envolvidos nessas interações que os alunos destacaram e começa também a negociar com a sala como essas representações poderiam ser realizadas em Libras, quais sinais seriam mais adequados para representar essas interações.

Os alunos concluíram, a partir das intervenções do Professor, que, para a hipótese de que os seres vivos estavam se escondendo no ambiente, a adaptação defensiva em termos científicos corresponde à camuflagem e que o sinal para isso seria ESCONDER; para a hipótese de que os seres vivos estão imitando o ambiente, o processo de interação em termos científicos é o mimetismo e que o sinal para isso seria PARECER, no sentido comparativo, pois há uma variação nesse sinal; e, por fim, para a hipótese de que a cor dos seres vivos indicava perigo, o processo de interação em termos científicos é o aposematismo e que o sinal para isso seria a composição do sinal de COR com o sinal de VENENO (Figura 14):

Figura 14: Sinais em Libras correspondentes aos termos científicos utilizado pelo Professor de ciências.

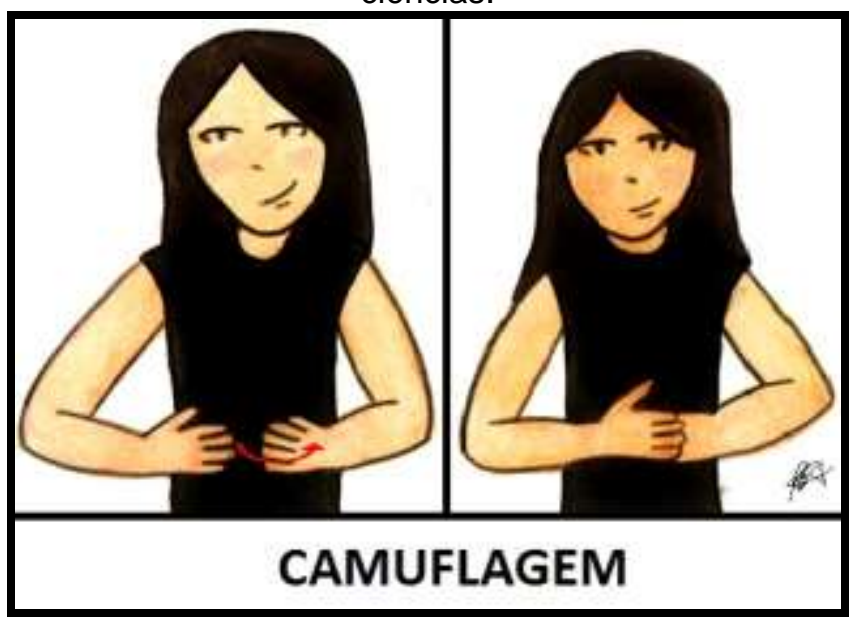




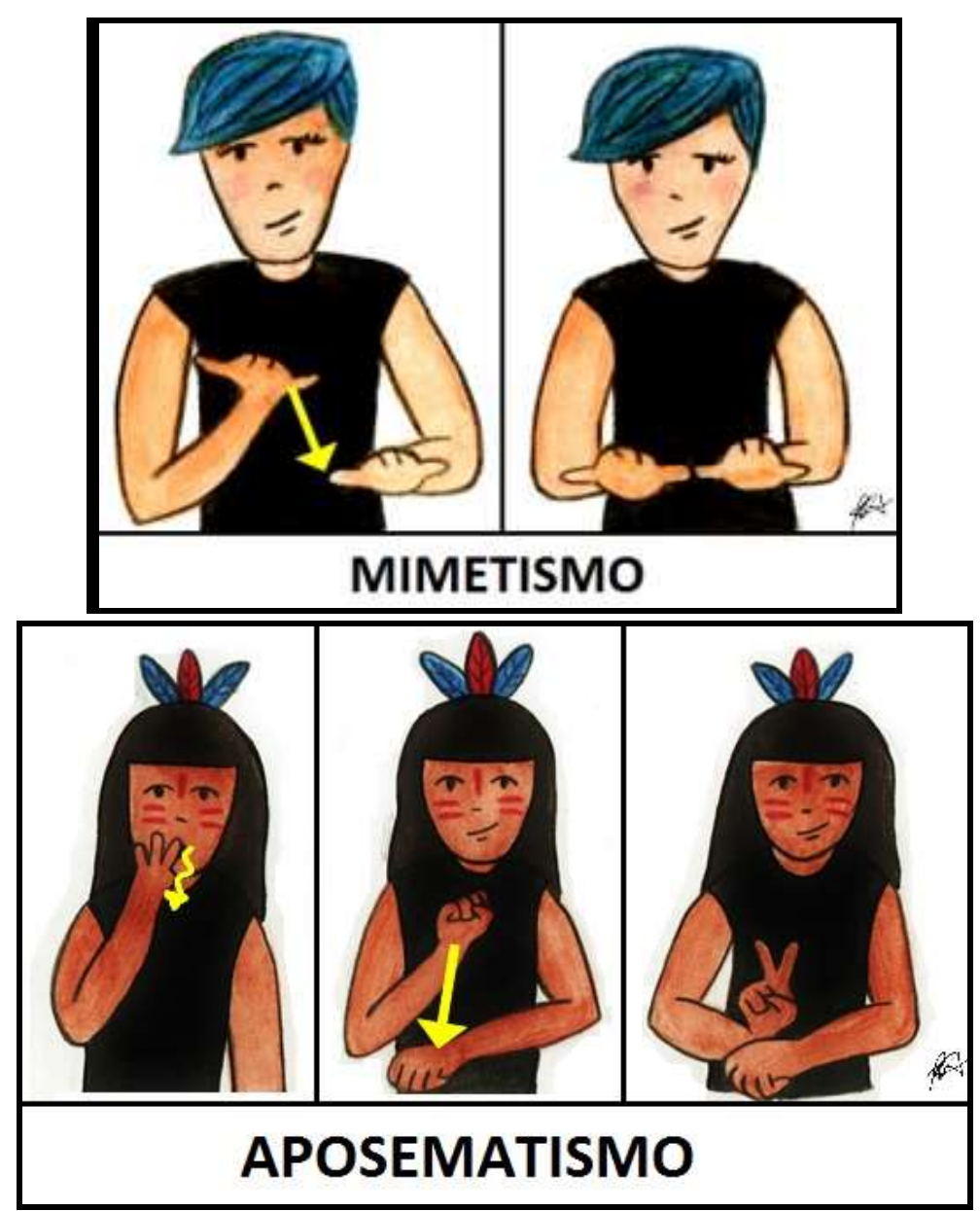

Fonte: Elaborada pela pesquisadora Beatriz Crittelli

Após trabalhar os conteúdos, o Professor fez uma atividade com os estudantes para verificar a compreensão de cada um perante o que foi estudado. Para isso, desenhou uma tabela na lousa com o nome de cada um e dividiu em cinco categorias, como se segue na representação abaixo (Tabela 05):

Tabela 05: Representação da lousa na atividade do Professor de ciências com os estudantes do sétimo ano $\mathrm{C}$.

\begin{tabular}{|c|c|c|c|}
\hline $\begin{array}{c}\text { Nomes/ } \\
\text { Categorias }\end{array}$ & Julia & Daniel & Felipe \\
\hline 1 & & & \\
\hline 2 & & & \\
\hline 3 & & & \\
\hline 4 & & & \\
\hline 5 & & & \\
\hline
\end{tabular}

Fonte: Elaborada pela pesquisadora Beatriz Crittelli 
Todos os estudantes copiavam da lousa essa tabela completa, com o nome de todos. As representações numéricas seguiam as categorias conforme a figura 15 :

Figura 15: Categorias estabelecidas pelo Professor para avaliação colaborativa

1. Velocidade da Libras: rápido, intermediário, devagar

2. Explicação geral do conteúdo: claro, médio, confuso

3. Explicação sobre o termo camuflagem: concordo, não concordo

4. Explicação sobre o termo mimetismo: concordo, não concordo

5. Explicação sobre o termo aposematismo: concordo, não concordo

Fonte: Elaborada pela pesquisadora Beatriz Crittelli

A partir dessas categorias, os alunos se posicionavam à frente da sala, um a um, e, com o apoio dos slides de aula do Professor, explicavam os conteúdos, enquanto os demais colegas os avaliavam seguindo o padrão da tabela, conforme uma avaliação colaborativa.

As explicações foram filmadas pelo Professor e as aulas posteriores seguiram com os alunos analisando qual das apresentações dos conteúdos foi a mais clara e com a melhor explicação em Libras.

Com os sinais já estabelecidos com a sala a partir das discussões, e mostrados na primeira atividade avaliativa, os alunos precisavam treinar também a escrita das palavras em português. Para isso, o Professor utilizou o método de "banco de palavras" com os alunos. Ao final de todas as aulas, ele perguntava em sala quais sinais diferentes eles aprenderam naquele dia, cada aluno apresentava pelo menos dois sinais que aprendeu e, após mostrar o sinal, o Professor pedia para soletrá-lo de modo a montar o banco de palavras na lousa. Cada aluno era responsável pelos sinais que apresentava, mas todos os alunos registravam em seus cadernos o banco de palavras de cada aula, sendo que esse banco era feito na maioria das aulas.

Os bancos de palavras representados nas figuras a seguir mostram as palavras levantadas em três dias diferentes (Figura 16, Figura 17, Figura 18): 
Figuras 16, 17, 18: Bancos de palavras levantados pelos alunos em sala e registrados pela pesquisadora em três dias de aula diferentes.

1. Camuflagem

2. Cavalo-marinho

3. Coruja

4. Pássaro

5. Borboleta
6. Peixe-pedra

7. Não-vê

8. Longe

9. Árvore
1. Flor-inseto

2. Trauma

3. Inchar

4. Lagarta

5. Pegar

6. Boboleta

7. Comparar

8. Perigoso
9. Cobra

10.Abelha

11. Inseto

12. Filho

13. Coruja

14. Macho

15. Fêmea
1. Sapo

2. Flor

3. Fungo

4. Vermelho

5. Veneno

6. Evitar

7. Perigo

8. Cores

9. Rosa

10. Alucinaçỗes
11. Laranja

12. Arco e flecha

13. Animais

14. Pegar

15. Amarelo

16. Năo pode

17. Pessoa

18. Marrom

19. Branco

Fonte: Elaborada pela pesquisadora Beatriz Crittelli

Nas aulas seguintes, o Professor continuou o trabalho de escrita com os alunos, pedindo-Ihes para elaborar três frases relacionadas a cada uma das adaptações defensivas. Em meio à elaboração das frases, se os alunos tivessem dúvidas de como escrever alguma palavra em português, deveriam consultar o banco de palavras das aulas anteriores e conferir com o colega responsável pela palavra a escrita correta. Mas, o professor percebeu que as frases não estavam compreensíveis na língua portuguesa, pois os alunos estavam confundindo bastante a ordem das palavras na frase. Isso levou 0 Professor a utilizar outra estratégia.

Nas aulas posteriores, antes de o Professor pedir as frases aos alunos, ele organizou uma tabela na lousa e pediu para copiarem em seus cadernos, conforme está representado na tabela 06 : 
Tabela 06: Tabela utilizada para organização das cadeias representadas na teia alimentar estipulada pelos estudantes.

\begin{tabular}{|c|c|c|c|}
\hline \multicolumn{2}{|c|}{ Animal } & Acontece? & Animal \\
\hline A & & & \\
\hline B & & & \\
\hline C & & & \\
\hline D & & & \\
\hline E & & & \\
\hline F & & & \\
\hline G & & & \\
\hline H & & & \\
\hline I & & & \\
\hline J & & & \\
\hline K & & & \\
\hline L & & & \\
\hline M & & & \\
\hline N & & & \\
\hline O & & & \\
\hline
\end{tabular}

Fonte: Elaborada pela pesquisadora Beatriz Crittelli

Entretanto, mesmo com essa tabela, o Professor percebeu que as frases ainda estavam confusas e com algumas informações repetidas, então, resolveu modificar novamente a tabela, enumerando as frases e acrescentando informações indicativas, conforme o modelo representado na Tabela 07, abaixo:

Tabela 07: Representação da tabela utilizada em aula pelo Professor de ciências com o Sétimo ano. A sequência numérica segue a ordem de frases referentes ao conceito de camuflagem decorrentes de outras atividades.

\begin{tabular}{|c|c|c|c|}
\hline $\begin{array}{c}\text { Números das } \\
\text { frases }\end{array}$ & Qual ser vivo & Parece o quê? & Por quê? \\
\hline 5 & & & \\
\hline 6 & & & \\
\hline 7 & & & \\
\hline 8 & & & \\
\hline
\end{tabular}

Fonte: Elaborada pela pesquisadora Beatriz Crittelli

O Professor percebeu que, assim, houve uma melhora na construção de frases, ficando mais satisfeito com o resultado. A Figura 19 mostra um exemplo de frases escritas por um aluno da sala: 
Figura 19: Frases escritas por um aluno a partir da tabela construída pelo Professor, representando a camuflagem.

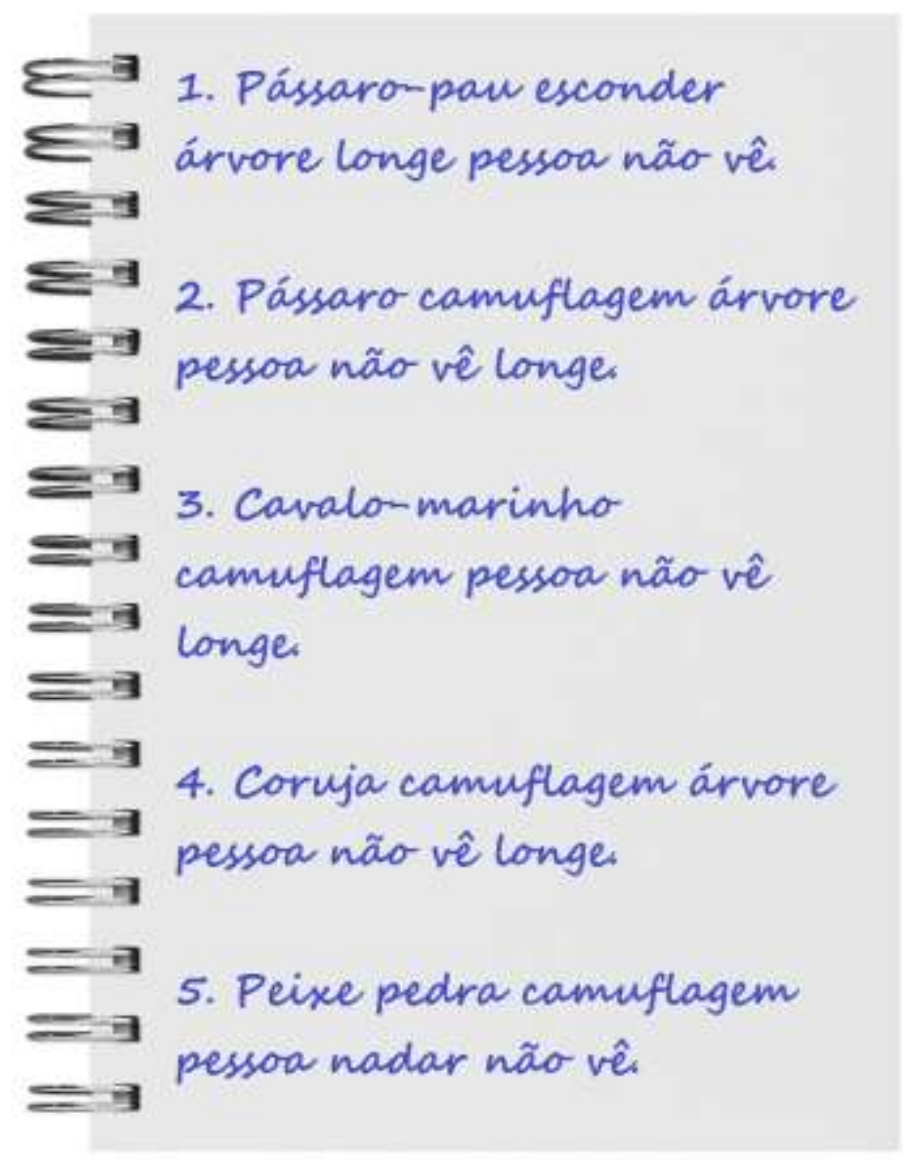

Fonte: Elaborada pela pesquisadora Beatriz Crittelli

Com essa estratégia estabelecida, o Professor seguiu as próximas aulas de escrita de frases com uma tabela que direciona frases para a descrição da adaptação defensiva aposematismo, como indica a Tabela 08:

Tabela 08: Representação da tabela utilizada em aula pelo Professor de ciências com o sétimo ano.

\begin{tabular}{|c|l|l|l|}
\hline Números das frases & Qual ser vivo & Quais são as cores? & As cores avisam o quê? \\
\hline 9 & & & \\
\hline 10 & & & \\
\hline 11 & & & \\
\hline 12 & & & \\
\hline
\end{tabular}

Fonte: Elaborada pela pesquisadora Beatriz Crittelli 
Depois dessa etapa de escritas de frases, iniciou-se a parte prática com os alunos. O Professor levou vários livros ilustrados com imagens de animais e pediu aos alunos que cada um fizesse três desenhos de animais. Nem todos os alunos fizeram três desenhos, mas a atividade prática se iniciou com doze desenhos.

Cada aluno recortou os desenhos a partir do contorno dos animais e iniciou-se a atividade prática no pátio do colégio.

O primeiro passo da atividade prática foi um reconhecimento espacial do jardim da escola. O Professor desenhou, na lousa, quatro possíveis formatos do pátio e pediu para os estudantes indicassem qual era o formato verdadeiro, observando se eles estavam atentos a esse local pelo qual passavam diariamente. Somente um aluno indicou o formato verdadeiro do jardim, os demais indicaram os outros formatos, conforme segue a Figura 20:

Figura 20: Representações do jardim da escola indicadas pelo Professor. Nessa atividade, os alunos indicavam qual formato eles julgavam ser o real, os números acima dos desenhos revelam a quantidade de alunos que indicaram cada representação.

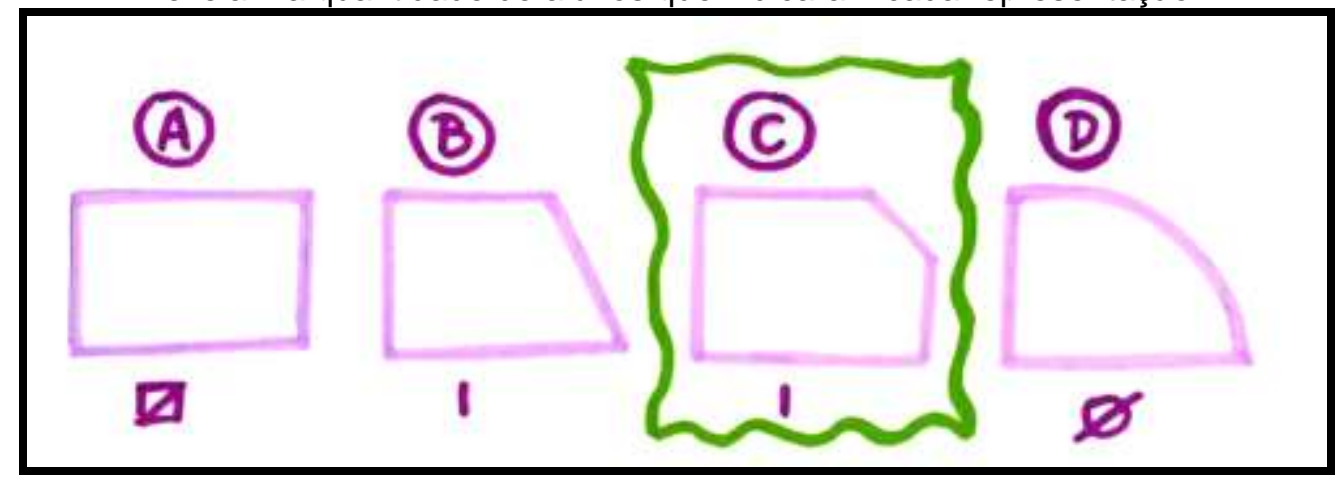

Fonte: Elaborada pela pesquisadora Beatriz Crittelli

Depois dessa etapa, o Professor levou os estudantes a um reconhecimento de território do jardim. Todos, com seus desenhos do jardim copiados da lousa, saíram da sala, foram ao jardim e fizeram representações da vegetação, a partir de uma perspectiva vista de cima.

Posterioremente, voltaram à sala e, para direcionar a atividade, o Professor fez, na lousa, uma representação final do pátio, a qual os alunos deveriam comparar com o desenho que fizeram. A representação segue conforme a Figura 21: 
Figura 21: Representação do pátio desenhada em lousa pelo Professor como base para a atividade prática da aula.

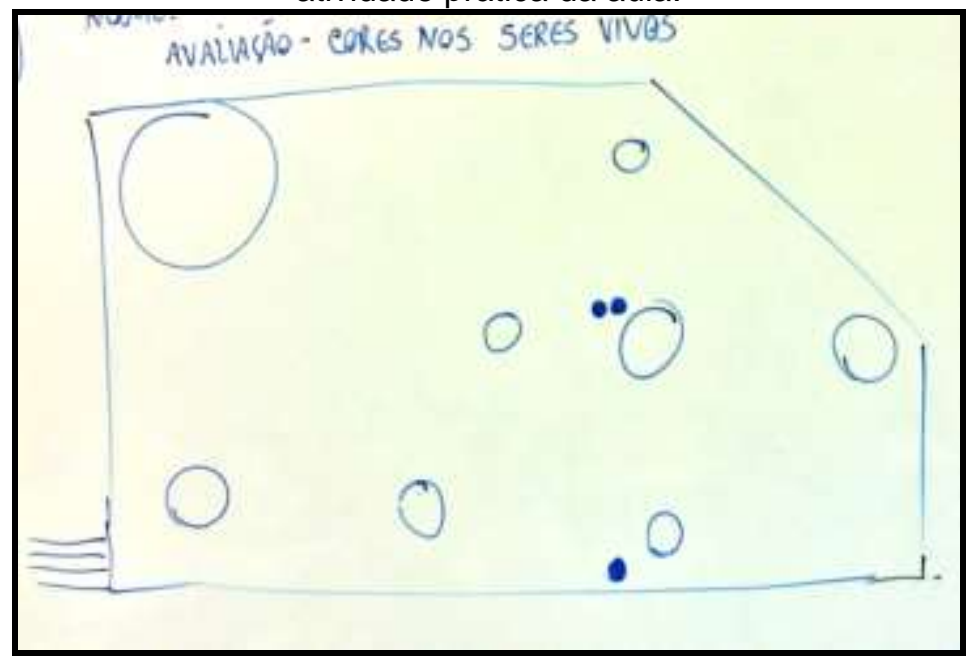

Fonte: Foto de Danilo Prado Ramos

Ao lado dessa representação do pátio, os alunos deveriam registrar, em seus cadernos, o número correspondente a cada animal (desenhados em sala nas aulas anteriores) e as adaptações defensivas: camuflagem, mimetismo ou aposematismo. Os desenhos foram enumerados e nomeados da seguinte forma (Figura 22):

Figura 22: Nomes dos animais desenhados pelos alunos e suas numerações correspondentes.

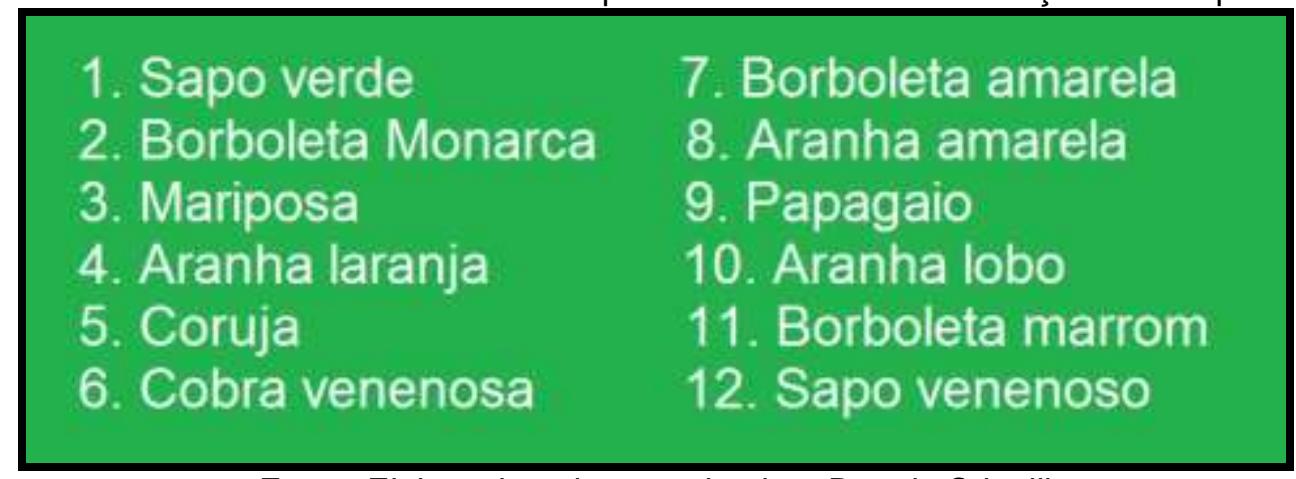

Fonte: Elaborada pela pesquisadora Beatriz Crittelli

A partir disso, cada número deveria ser relacionado às seguintes categorias (figura 23): 
Figura 23: Categorias a ser indicadas na atividade do pátio seguindo as adaptações defensivas de interação ecológica estudadas.

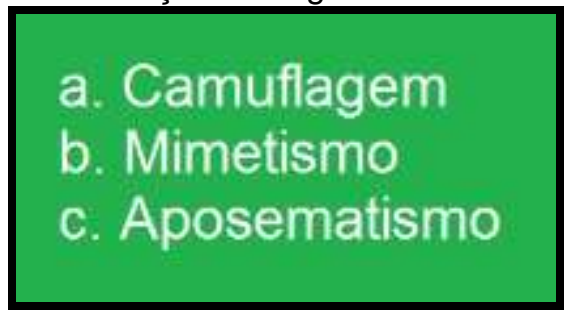

Fonte: Elaborada pela pesquisadora Beatriz Crittelli

Ao todo, foram doze desenhos e, com eles em mãos, o Professor dividiu a sala em dois grupos, sendo que foram todos para o jardim. A metade dos estudantes que estava em sala ficava esperando a outra metade "esconder" os desenhos no jardim. Com isso, observei quais critérios os alunos utilizavam para "esconder" esses desenhos, se era de acordo com as estratégias adaptativas que haviam estudado, mimetismo, camuflagem e aposematismo, ou aleatoriamente.

Após um grupo ter escondido os desenhos, o outro grupo saía da sala para identificar os animais desenhados escondidos e relacioná-los às estratégias adaptativas. Essa atividade ocorreu em duas aulas, os dois grupos de estudantes participaram de todas as etapas.

O desenho final do pátio com a reprodução dos animais e as adaptações defensivas que representavam é apresentado na figura 24, abaixo:

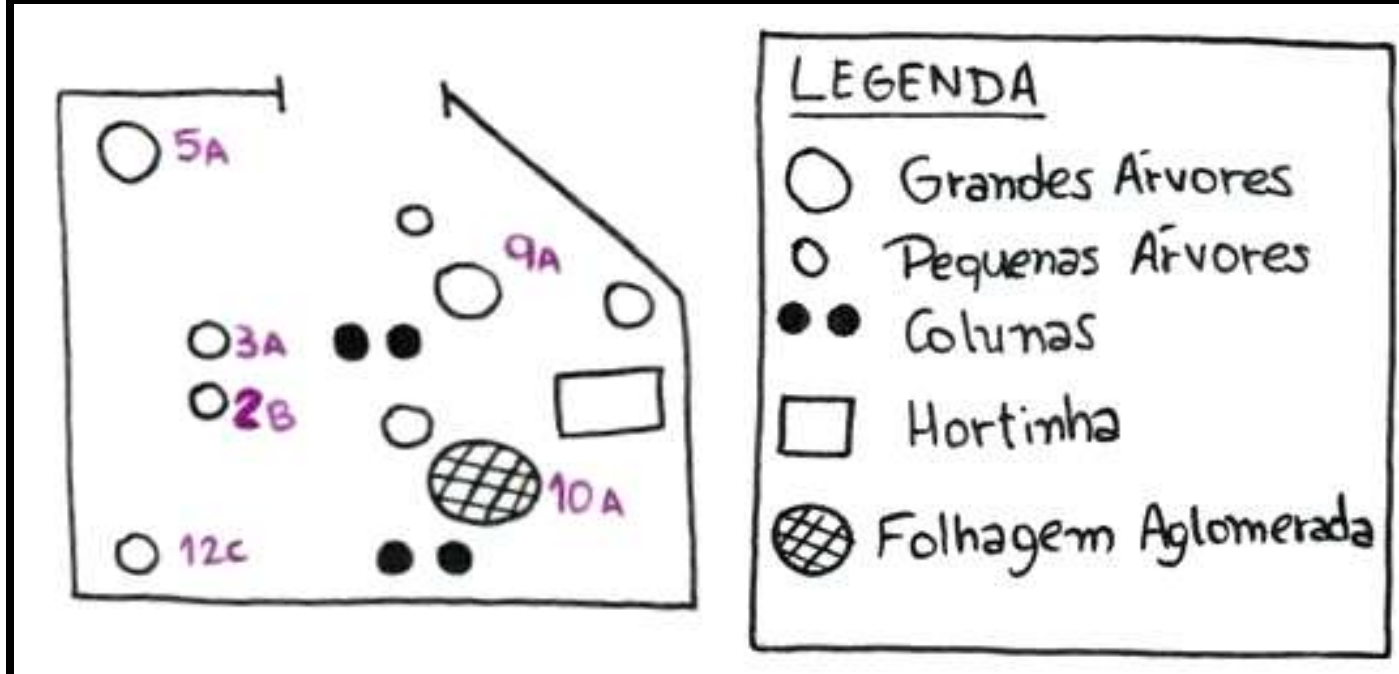

Fonte: Elaborada pela pesquisadora Beatriz Crittelli 
Após a atividade no pátio, o Professor resgatou os desenhos (dois foram danificados na atividade prática) e os colou na lousa. Então, ele perguntou aos alunos: qual animal se alimenta de qual? Iniciando, assim, o desenvolvimento do conteúdo relativo a predadorismo e teia alimentar. Os alunos colaram em espaços aleatórios na lousa e, com isso, começaram a desenhar setas que representavam qual animal se alimentava de qual, formando, no processo, uma teia alimentar, conforme a imagem abaixo (Figura 25):

Figura 25: Representação da teia alimentar com o posicionamento das setas estipuladas pelos estudantes, evidenciando o direcionamento de qual animal era predador e qual era presa.

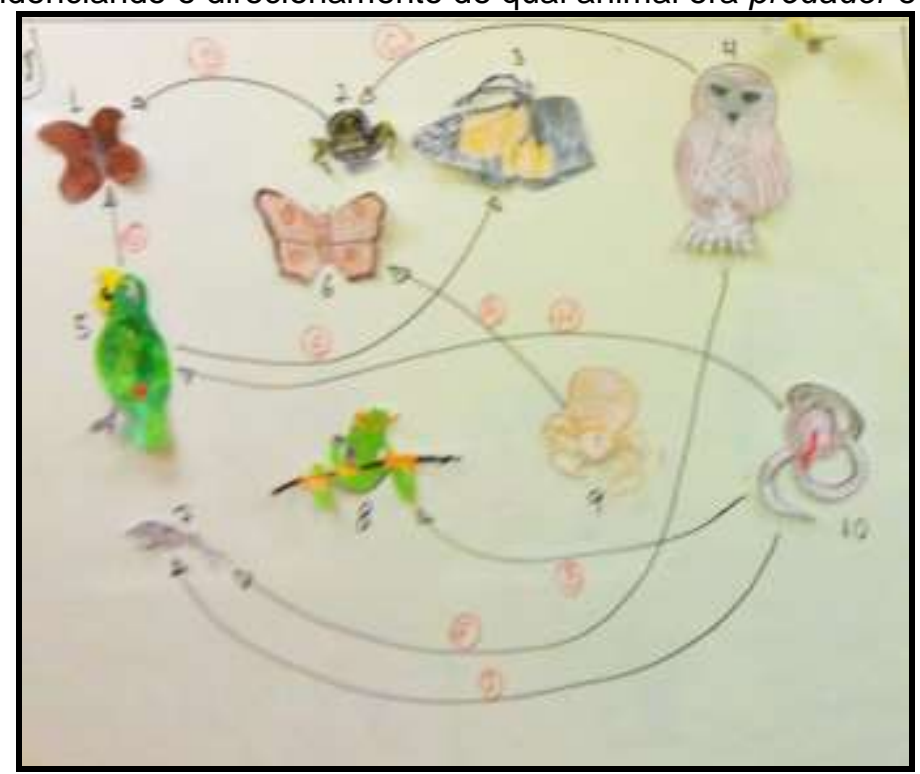

Fonte: Foto de Danilo Prado Ramos

A partir da representação da teia alimentar na lousa, o Professor acrescentou letras nas setas para organizar cada cadeia presente na teia (como é possível observar na imagem acima), retirando as imagens dos animais e deixando somente os números.

Com esse desenho copiado no caderno, o Professor fez uma tabela na lousa que seguia uma lógica para os estudantes construírem as cadeias com uma maior facilidade (tabela 09): 
Tabela 09: Tabela utilizada para organização das cadeias representadas na teia alimentar estipulada pelos estudantes.

\begin{tabular}{|c|c|c|c|}
\hline \multicolumn{1}{|c|}{ Animal } & Acontece? & Animal \\
\hline A & & & \\
\hline B & & & \\
\hline C & & & \\
\hline D & & & \\
\hline E & & & \\
\hline F & & & \\
\hline G & & & \\
\hline I & & & \\
\hline \multicolumn{2}{|c|}{ Fonte: Elaborada pela pesquisadora Beatriz Crittelli }
\end{tabular}

O Professor acrescentou letras ao esquema da teia alimentar na lousa para os estudantes copiarem no caderno e, assim, explicarem essas novas relações entre os animais. As novas setas da representação da teia alimentar foram desenhadas de outra cor para diferenciar as novas interações, além disso, as figuras dos animais foram retiradas e foi escrito um número no lugar. A partir dessa nova representação (Figura 26), o Professor solicitou que os alunos copiassem da lousa as informações conforme o modelo abaixo:

Figura 26: Representação da cadeia alimentar com novas setas estipuladas pelo Professor e destacadas em outra cor, representando novas interações dentro da teia alimentar.

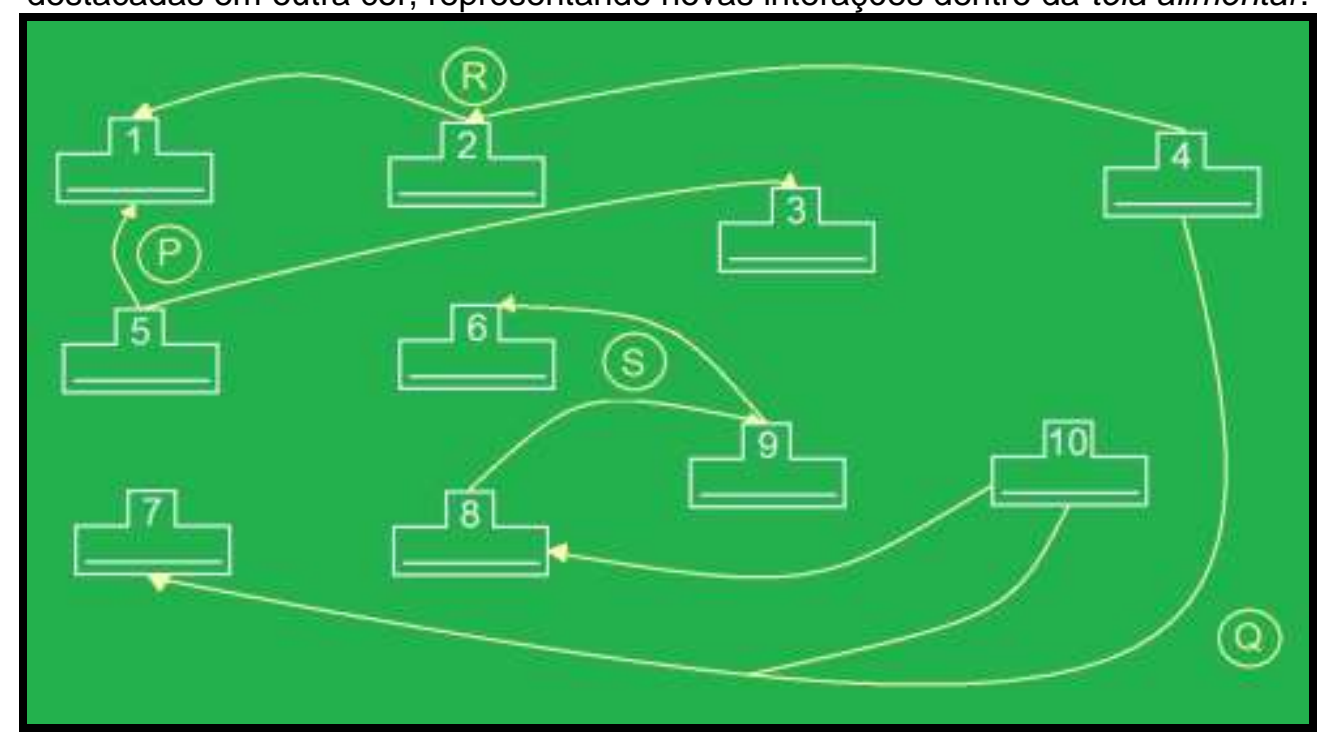

Fonte: Elaborada pela pesquisadora Beatriz Crittelli 
A partir das novas setas indicadas por letras, o Professor montou um novo esquema para construção das frases, seguindo a figura 27:

Figura 27: esquema de construção de frases para a representação dos novos processos da teia alimentar.

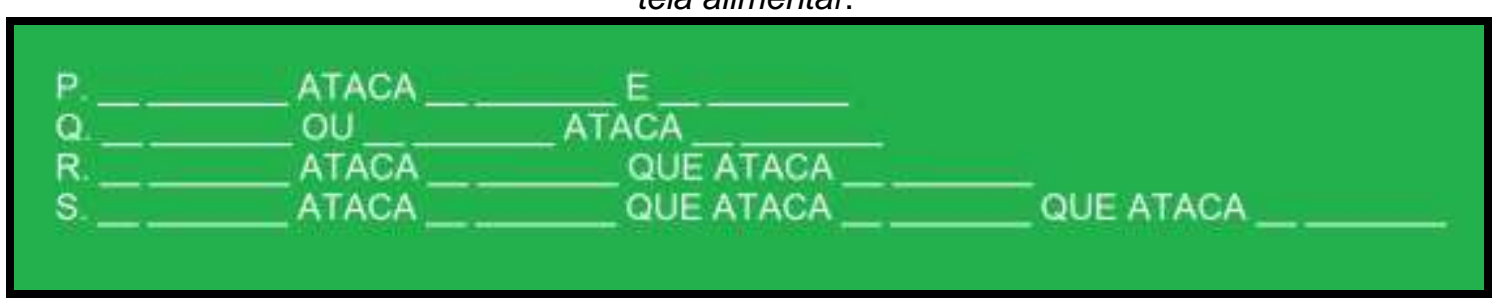

Fonte: Elaborada pela pesquisadora Beatriz Crittelli

Em cada espaço, os estudantes deveriam preencher com o número do animal e o nome correspondente. Com isso, o Professor observava se estavam fazendo as associações corretas e se estavam interpretando o esquema de uma forma mais ampla e não limitada às cadeias.

Após todas as atividades, o Professor começou a esclarecer e combinar com a sala como seria a avaliação final da disciplina. Explicou aos estudantes o método da avaliação através da "rubrica", um método progressivo que parte da retomada de conceitos básicos até uma reflexão mais aprofundada sobre o conteúdo, estabelecendo critérios. Para cada aluno avaliado, os alunos avaliadores selecionavam a categoria correspondente ao desempenho de quem estava em avaliação, seguindo os tópicos presentes na figura abaixo: 
Figura 28: Tópicos da avaliação dos alunos, combinados na sala entre todos.

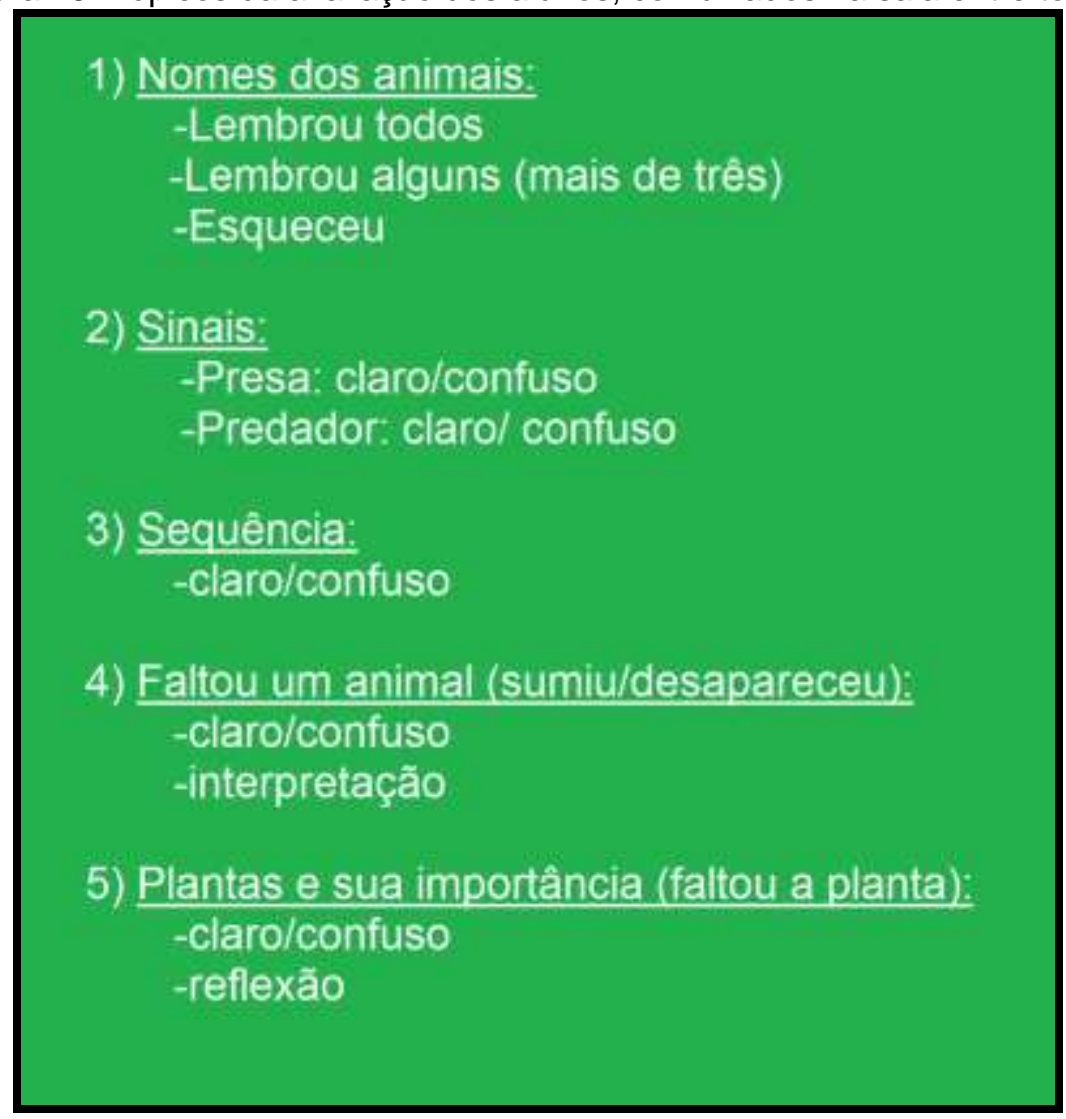

Fonte: Elaborada pela pesquisadora Beatriz Crittelli

Foi sorteada a ordem dos alunos a apresentar as explicações indicadas enquanto os demais copiavam em seus cadernos o esquema orientador para a avaliação de cada estudante. As avaliações foram registradas em vídeos.

Os nomes dos animais, já escritos na lousa pelo Professor, foram organizados de acordo com os desenhos realizados nas atividades anteriores. Os alunos iniciavam a avaliação desenhando com setas uma teia alimentar entre os animais e, depois de terminar e indicar os sinais dos animais, o primeiro ponto de avaliação verificava se o estudante se recordava de todos os nomes, poucos ou nenhum.

Após essa etapa, o Professor selecionava uma parte da teia, em especial dois animais, e indagava ao aluno, naquele ponto da teia, sobre qual animal seria a presa e qual seria o predador.

Para esse segundo tópico da avaliação, foi verificado se a explicação dada pelos alunos sobre quem é a presa e quem é o predador estava clara ou confusa. 
No terceiro momento, o Professor selecionava outra parte da sequência com três animais e pedia ao aluno que explicasse essa cadeia alimentar. Nesse momento, os estudantes deveriam avaliar se a sequência estava clara ou confusa no sentido de verificar se a explicação estava sendo realizada em Libras ou português sinalizado.

Para o quarto tópico da avaliação, o Professor riscava um dos animais da cadeia anteriormente selecionada e, com isso, instigava o aluno a saber 0 que acontecia no futuro, caso esse animal fosse extinto. Assim, todos avaliavam como foi a interpretação desse aluno perante esse novo questionamento.

Por fim, o Professor acrescentava uma planta e selecionava uma cadeia alimentar dentro da teia que a contemplasse. $O$ aluno deveria apresentar a sequência com a planta e, posteriormente, o Professor a riscava, indagando novamente o que aconteceria no futuro caso não existissem mais plantas. Com isso, os estudantes deveriam seguir a avaliação conforme o quarto tópico.

As avaliações registradas em vídeo totalizavam um número maior que cinco vídeos, porém, houve um problema com os arquivos que foram corrompidos por uma falha no computador, impossibilitando a recuperação dos demais registros.

\subsection{Ferramentas utilizadas pelo Professor em suas aulas de ciências}

Nas aulas de ciências, trabalha-se uma linguagem específica com os alunos: a linguagem científica. Nela, os estudantes encontram novos termos, novos conhecimentos, imagens que nunca viram antes ou já viram e não se atentaram. Um Professor, para unir esses alunos aos novos conhecimentos e linguagem, deve utilizar, em suas aulas, variados tipos de ferramentas de ensino. 
Ao se tratar de um ensino direcionado aos alunos Surdos, o Professor deve se atentar também ao trabalho com as diversas línguas e linguagens em suas aulas: português, Libras, linguagem científica, linguagens escritas, gráficas, textuais etc., e, com isso, promover práticas que tornam possível uma união entre essas áreas.

No processo de aprender ciências, os alunos precisam aprender novas palavras (no caso, sinais), nova estrutura textual, o que pode ser comparado ao aprendizado de outro idioma (BARGALLÓ, 2005). A autora afirma que a linguagem cotidiana é insuficiente para expressar a natureza dos fenômenos tratados pela ciência e, por isso, justifica-se o vocabulário específico, incluindose também: gráficos, mapas, símbolos matemáticos, equações, entre outros elementos.

De acordo com Bargalló (2005), nas aulas de ciências, os alunos devem tentar explicar os fenômenos naturais com suas próprias palavras e, conforme vão adquirindo novos conceitos, essa linguagem vai se aprimorando, indicando que a atividade científica também é uma atividade linguística e que aprender ciências é como aprender outro idioma.

A ciência abre a possibilidade de se entender o mundo de uma outra forma, e essa nova visão dos fenômenos observados necessita de novas formas de expressão (BARGALLÓ, 2005). A autora indica que os alunos aprendem ciências enquanto aprendem a descrever, justificar, argumentar, definir os fenômenos observados na natureza, em representações de experimentos ou em laboratórios.

Para treinar e desenvolver essas habilidades, o professor pode utilizar diferentes ferramentas de ensino e, de acordo com Laburú, Arruda e Nardi (2003, p. 251), "todos os modelos e metodologias, inclusive as mais óbvias, têm vantagens e restrições". Os autores ainda afirmam:

Os estudantes variam em suas motivações e preferências, no que se refere ao estilo ou ao modo de aprender, e mesmo na sua relação com o conhecimento. Isso sem mencionar as suas habilidades mentais específicas, ritmos de aprendizagem, nível de motivação e interesse para uma determinada disciplina, persistência dedicada a um problema, experiências vividas pelo grupo social a que pertencem (LABURÚ; ARRUDA; NARDI, 2003). 
Tais fatores apontados pelos autores influenciam diretamente na sala de aula e na profundidade da aprendizagem, também na escolha e definição da estratégia metodológica. Desse modo, uma ação educacional que toma como base um único estilo didático só abarca as necessidades de um tipo particular de aluno (ou alunos), em detrimento de outros (LABURÚ; ARRUDA; NARDI, 2003).

Ao longo do semestre de coletas de dados, direcionei minha atenção a descrever e detalhar as ferramentas utilizadas pelo Professor em suas aulas e a forma como contextualizava a linguagem científica para os alunos.

Durante a entrevista, perguntei ao Professor como ele planejou a sequência de aulas para o primeiro subtema que abordara: camuflagem, mimetismo e aposematismo. O Professor iniciou sua explicação citando qual é seu referencial teórico base para planejar suas ações:

\begin{abstract}
(...) quando se está falando de aprendizagem, sendo o referencial teórico do Vigostki, com o nível de desenvolvimento real e você, a partir do nível de desenvolvimento real, você vai para a zona de desenvolvimento proximal. Só que a gente está sempre usando uma coisa que eles podem fazer sozinhos. Para entender um pouco disso, para tentar desenhar um pouco disso, isso no intuito de conhecer o aluno, e depois vou estabelecer alguns é... objetivos que vou precisar influenciar um pouco mais. Não sei se influenciar é a melhor palavra, mas vou precisar intervir de uma forma um pouco mais constante (...) (transcrição literal retirada da entrevista).
\end{abstract}

O Professor afirma também, em sua entrevista, que preza o diálogo em suas aulas, indicando que a participação do aluno é fundamental para organizar suas práticas e, juntos, irem construindo saberes e adaptando as atividades com a finalidade de aproximá-los desse conhecimento científico. Mas, afirma também que essa prática foi se consolidando ao longo do tempo e ao longo de sua aprendizagem em língua de sinais, como menciona em sua fala:

(...) tinha sentido que realmente precisava disso, precisava assisti-los mais, precisava ver eles se expressando mais para entender o que eles estavam expressando para eu me desenvolver na língua e isso de certa forma acabou se tornando parte da minha estratégia de ensino (...) (transcrição literal retirada da entrevista).

Com o "banco de palavras" sendo utilizado nas aulas para trabalhar o português, os estudantes recorriam uns aos outros para se recordarem da 
escrita das palavras em português. Com isso, começaram a criar uma boa interação na aula sem recorrer sempre ao Professor para sanar esse tipo de dúvida.

Um exemplo que ocorreu com o uso do banco de palavras: um estudante estava em dúvida sobre como se escrevia em português a palavra "coruja", sinalizando o termo em Libras. O estudante responsável por esse termo se prontificou e começou a soletrar a palavra para o aluno que estava com dúvida, mas este compreendeu a palavra como RORUJA. O estudante responsável pelo termo soletrou a palavra três vezes até o estudante com dúvida a escrever corretamente.

Para trabalhar o conteúdo de teia e cadeia alimentar, em vez de o Professor iniciar com a explicação do que é uma cadeia alimentar e, a partir dela, ensinar sobre a teia alimentar, ele explicou tudo a partir dos conhecimentos prévios que os estudantes possuíam em relação aos animais e, com os desenhos dos animais colados na lousa, estabeleceu uma relação alimentar entre eles, indicando com setas. Assim, os alunos puderam perceber como essas interações ocorrem no ambiente de uma maneira geral e não particular. O conceito de cadeia alimentar foi trabalhado selecionando-se partes da teia, possibilitando que, em todo o tempo, os estudantes vissem o processo de uma forma ampla e, a partir disso, o especificassem.

Durante as aulas de ciências, pude observar o Professor utilizando diversas ferramentas, tais como: vídeos explicativos produzidos pelos alunos, imagens, ilustrações, esquemas, tabelas, busca de imagens e informações em livros, aulas em slides, avaliação colaborativa entre os alunos, atividades em ambientes extraclasse, entre outras. Com base nos dados obtidos, pode-se dizer que o Professor utilizou-se de pluralismo metodológico em suas aulas, tal como proposto por Laburú; Arruda e Nardi (2003), que afirmam ser adequado o uso de procedimentos metodológicos que vão contra a utilização:

(...) de um conjunto único, frio, restrito, de regras que se pretenda serem universalmente aceitas e principalmente válidas e verdadeiras para qualquer e toda situação de aluno, professor, sala de aula, faixa etária, escola, etnia cultural, lingüística, matéria, conceito, etc.. (LABURÚ; ARRUDA; NARDI, 2003, p. 252). 
$\mathrm{Na}$ entrevista, o Professor ressaltou a importância de explorar os aspectos visuais em suas aulas, como afirma no trecho a seguir: "(...) você precisa explorar a visualidade, você precisa explorar o que eles vão ver, então, nas aulas, de uma forma geral, eu sempre usei muito desenho, desenho que trazia na hora, desenho que eu fazia, foto, construções a partir de esquemas foram surgindo mais recentemente, tudo para que pudesse favorecer melhor um pouco mais do que estava sendo construído (...)". Mas ressaltou que mesmo as imagens podem trazer problemas pelo fato de o professor apoiar suas observações no que a própria imagem diz e "deixar de lado" a língua de sinais.

O uso de imagens é uma estratégia com a qual se deve ter muito rigor em sua utilização. $O$ trabalho com diferentes recursos visuais está descrito pela autora Surda Campello (2008) como "pedagogia visual", sendo este um processo para a escolarização de Surdos. A própria língua de sinais é uma língua pautada nas habilidades visuais e motoras, com isso, durante as aulas, os professores precisam utilizar diversos elementos visuais para facilitar a aprendizagem, pois estes são recursos complementares à própria visualidade da Libras. No entanto, os professores não devem se restringir a esse aspecto, pois o Surdo é um ser humano constituído também por outros sentidos, não se resumindo à visualidade, por mais que essa seja uma aspecto fundamental a ele.

Martins, Gouvêa e Piccinini (2005) afirmam que as imagens são "importantes recursos para a comunicação de ideias científicas" (p. 38). Também, possui fundamental importância como um recurso para visualização, contribuindo para a compreensão de textos científicos e desempenhando um papel fundamental para conceitualização científica e formação de ideias (MARTINS; GOUVÊA; PICCININI, 2005).

De acordo com as autoras Albuquerque, Sá e Carneiro-Leão (2014), com o uso da imagem em aula, é possível despertar o interesse dos alunos e auxiliar na visualização de elementos, muitas vezes abstratos, de um determinado conceito científico. Para os estudantes Surdos, a imagem pode também auxiliá-los no processo de construção de sinais ou classificadores para representar o fenômeno observado. 
Campello (2008) afirma que "há uma urgente necessidade de repensar a visualidade e descentrar das categorizações linguísticas e também da visão fonocêntrica" (p. 152). Para isso, é necessário ter conhecimento sobre as especificidades do signo visual, sua apreensão e processamento (CAMPELLO, 2008).

Com o foco em recursos visuais, durante as aulas foi observado que 0 Professor também trabalhou diferentes habilidades com os alunos, como observação e avaliação dos conteúdos representados pelos seus colegas nas avaliações em vídeos, raciocínio lógico e estratégias nas atividades envolvendo o pátio. Além disso, o Professor trabalhou também a escrita do português nas atividades de sala envolvendo as tabelas e o "banco de palavras". As interações decorrentes dessas atividades serão descritas mais especificamente no tópico a seguir.

Na famosa afirmação "uma imagem vale mais do que mil palavras", é preciso ter cautela quando tal imagem está aplicada ao contexto de ensino de ciências em sala de aula. Afinal, é necessário que a imagem científica esteja acompanhada de palavras, explicações, comparações e orientações, principalmente quando são utilizadas para estudo e compreensão de conceitos científicos (ALBUQUERQUE; SÁ; CARNEIRO-LEÃO, 2014).

$\mathrm{Na}$ mediação entre a imagem e o texto, no caso das aulas em Libras, imagens e conversas realizadas pelo professor em interação com os estudantes possibilitam diferentes apreensões do significado que a imagem pretende repassar (ALBUQUERQUE; SÁ; CARNEIRO-LEÃO, 2014). De acordo com as autoras, "quanto maior for o espaço para que estes significados sejam negociados, maior a troca de conhecimentos entre os pares, e maior a compreensão do conceito" (ALBUQUERQUE; SÁ; CARNEIRO-LEÃO, 2014, p. 7141).

Pode-se dizer que o professor de ciências é também um professor de língua, já que é necessário promover, nas aulas, um bom conhecimento da linguagem específica da ciência (BARGALLÓ, 2005). No caso do contexto bilíngue, agregado a esse conhecimento da linguagem científica, o professor também deve ter um bom conhecimento das linguagens que envolvem 0 português e, principalmente, a Libras. É preciso que o professor planeje atividades para a aprendizagem da linguagem científica no contexto da Libras 
porque isso possibilita aos alunos Surdos se apropriar dos conhecimentos científicos (BARGALLÓ, 2005).

Assim como foi observado nas aulas, pode-se afirmar que "todo ensino, como atividade humana, é intercultural, devido às múltiplas identidades microculturais de todos os estudantes" (LABURÚ; ARRUDA; NARDI, 2003, p. 252). Tanto a diversidade cultural entre estudantes quanto em relação ao professor. Neste caso, Surdos e ouvinte, atrelados à diversidade das culturas linguísticas e, também, da própria cultura científica (LABURÚ; ARRUDA; NARDI, 2003).

\subsection{Interações entre os alunos Surdos e Professor ouvinte no contexto científico}

Ao constatar a situação em que um Professor ouvinte ministra aulas de ciências para alunos Surdos, a primeira pergunta que veio à minha mente foi: "como ocorre essa interação nas aulas? " Já imaginava que a resposta a essa pergunta estava muito além da língua de sinais utilizada para a comunicação, pois esse problema exige do Professor um exercício constante de se colocar no lugar do outro em um contexto que ele não vivencia.

A caderneta de campo foi o principal instrumento utilizado para analisar a interação entre os estudantes Surdos e o Professor, pois, nela, o docente anotava todos os momentos observados em sala, as reações dos alunos, as atividades desenvolvidas, os comportamentos e, principalmente, a forma como interagiam com o Professor e vice-versa.

Para a interação fluir naturalmente entre o Professor e os estudantes, o docente sempre se utilizava de diferentes recursos didáticos em suas aulas, priorizando recursos que tinham imagens. A partir dessas imagens, gerava discussões nas aulas, incentivando os alunos a exporem suas dúvidas em relação ao tema.

Darei um exemplo para ilustrar esse tipo de situação. Nas primeiras aulas introdutórias sobre as relações ecológicas, o Professor levantava 
questões aos alunos a partir de imagens, tais como: "porque essa planta se parece com um inseto? "; "porque essa cobra que não possui veneno tem cores tão parecidas com essa outra que possui? "; "porque esses animais possuem cores tão fortes? O que elas representam? ".

Dessa maneira, os estudantes expressaram suas opiniões e chegaram às conclusões: alguns animais se escondem no ambiente para se proteger do inimigo; outros animais se assemelham em sua aparência física com outros que são venenosos, confundindo o predador; e, por fim, alguns animais venenosos possuem cores chamativas que são reconhecidas pelos predadores como sinal de alerta, evitando que sejam predados. Assim, introduziu-se o conceito de camuflagem, mimetismo e aposematismo.

Nas aulas decorrentes, o Professor filmou as explicações sobre essas adaptações defensivas que os alunos criaram a partir de seus slides de aula. Em conjunto com os alunos, os vídeos eram avaliados e um deles era escolhido para ser usado como referência para os trabalhos a ser desenvolvidos nas próximas aulas.

Durante a prática da elaboração do banco de palavras, percebi que os estudantes Surdos possuem muita dificuldade com a representação escrita das palavras e a associação de letras, uma vez que não fazem uma associação com os sons e escrita. Pode-se dizer que essa dificuldade está diretamente ligada ao processo de significação (VIGOTSKI, 1998), pois as palavras escritas e lidas não apresentam significados reconhecíveis a esses alunos pelo fato de nunca terem escutado o som dessas palavras. A audição permite aos ouvintes uma primeira aproximação com os significados das palavras através do som e, consequentemente, a escrita representa esse significado. Já, aos alunos Surdos, resta a memorização, pois a lógica sonora das palavras não Ihes faz sentido, sendo assim, as palavras escritas são vazias de significado.

Em um momento de aula, uma estudante perguntou como escrevia a palavra lagarta, perguntando em Libras. Pelo "banco de palavras", a estudante responsável pelo termo começou a soletrar L-A-R e retomou ao caderno com a palavra escrita em português por não recordar a ordem das letras dessa palavra. Finalizou digitando a palavra LARARUA e, com isso, o Professor fez uma intervenção, pedindo para ela conferir novamente no caderno se a palavra 
fora soletrada corretamente. Depois de algumas tentativas, a aluna soletrou da forma adequada.

A partir do banco de palavras, o Professor retoma o vídeo de explicações do conteúdo, selecionado pelos estudantes, e propõe a atividade de escreverem quatro frases em português explicando a camuflagem. Como a construção de frases em Libras é diferente da construção em língua portuguesa (LEITE, 2008), essa diferença gramatical é expressa quando os estudantes Surdos escrevem em português. Como exemplo, apresento as frases de diferentes estudantes na Figura 19, já exposta anteriormente.

É possível observar um padrão nas frases, primeiro, o nome do animal e depois, a adaptação defensiva que realiza, no caso, camuflagem, o ambiente em que realiza a adaptação e, por fim, o resultado. Esse padrão de frases pode ter se realizado a partir das tabelas de estruturação de frases que o Professor montou em outras atividades, mas, para um usuário da língua portuguesa, a frase pode continuar confusa, pois as duas línguas têm organizações sintáticas diferentes.

Nessa aula, enquanto o Professor verificava os registros escritos, observou que uma aluna utilizava constantemente a palavra esconder ao invés da palavra camuflagem. Perguntei ao Professor se ela estava registrando da forma correta, então, o Professor interferiu dizendo que, nas aulas de Ciências, o sinal (vide Figura 14) representa a palavra camuflagem, já, corriqueiramente, esse sinal expressa o termo esconder.

Albres (2005) aponta que as dificuldades de leitura e escrita apresentadas por um estudante Surdo são resultado "da falta de métodos e procedimentos de ensino suficientemente eficazes para que o Surdo alcance correção na sua produção de leitura e escrita" (p. 41). A autora afirma que a proposta de educação bilíngue do Brasil corre um risco porque, ao invés de propiciar a formação em duas línguas (português e Libras), está tendendo à formação de Surdos monolíngues, pela precariedade da língua portuguesa escrita observada e também pela falta de proficiência em língua de sinais por parte dos professores. Em consequência, tal situação propicia uma formação deficitária aos alunos Surdos também (ALBRES, 2005). 
No decorrer das aulas, o Professor observou que, conforme o conteúdo se aprofundava, os alunos se acostumavam com suas atividades de sala, escreviam as frases mais rapidamente e o banco de palavras aumentava.

Em cada atividade de formação de frases, o Professor utilizava diferentes tabelas para facilitar a formação de frases dos alunos e percebeu que esse formato facilitou também para os estudantes organizarem suas ideias.

$\mathrm{Na}$ atividade do jardim, percebi que a maioria dos estudantes escondeu o desenho em locais que possuíam a mesma cor do animal desenhado, por exemplo: mariposa no tronco da árvore, papagaio nas folhagens verdes, aranha em meio a gravetos, entre outros. Mesmo utilizando a cor como parâmetro principal, os alunos procuravam deixar os desenhos em locais que representavam seu habitat natural. Em resumo, os estudantes utilizaram dois critérios para a escolha do local para colocar seu desenho: coloração de fundo e compatibilidade do animal representado com o habitat que ele supostamente ocupa na natureza. Por exemplo, nenhum pássaro foi posicionado em moitas ou na grama, mesmo que a cor fosse semelhante, os alunos preocupavam-se com o habitat natural em que poderiam encontrá-lo, como pode ser observado nas figuras 29 e 30 .

Figuras 29 e 30: Alunos na atividade do jardim do Colégio, posicionando os animais nos locais que acreditavam ser seus habitats. Na figura 29, o aluno coloca o pássaro em um local mais alto, com a coloração parecida, e, na figura 30 , o aluno posiciona a cobra em meio às folhagens.

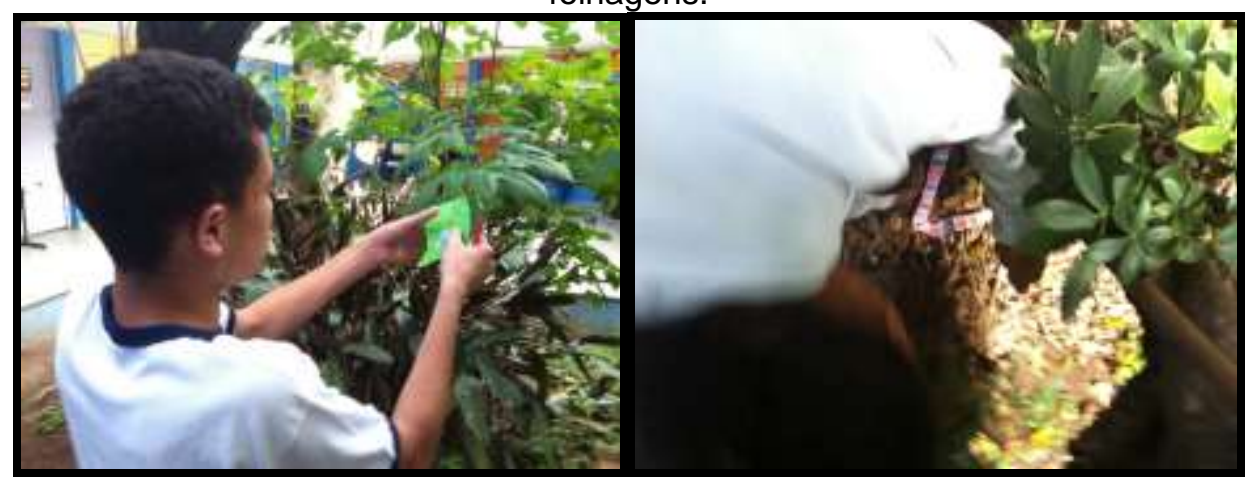

Fonte: Foto de Danilo Prado Ramos

Durante as aulas, o Professor interligou as atividades de forma que os alunos percebessem uma sequência lógica entre os conteúdos. Os mesmos animais apresentados no início das aulas eram representados até o final das 
aulas, acompanhados em diferentes tipos de interações (uns com os outros, com o ambiente, ora sendo presas, ora predadores), de modo que a ideia de teia alimentar fosse construída. Os conteúdos eram trabalhados de uma maneira bastante associada e contínua e, com as aulas decorrentes de avaliação, o Professor pôde constatar se essa sequência foi clara e lógica aos alunos, ou não. Devido à sua complexidade, esse tópico será melhor abordado nos próximos capítulos.

A construção dos conceitos em Libras, construídos por essa sequência de aulas, será discutida nos próximos capítulos.

Entre as aulas de ciências, pôde-se constatar que houve argumentação e explanação nas interações entre os alunos e o Professor, mas o foco desta pesquisa é em como ocorreu a construção de conceitos científicos, assunto que será melhor abordado nos próximos tópicos.

\subsection{Atividades avaliativas finais e a inserção dos alunos no contexto de ensino de ciências}

Os vídeos utilizados para a pesquisa foram filmados pelo próprio Professor, pois foram utilizados como um instrumento de avaliação em suas aulas.

Albres (2005) afirma que a avaliação para os alunos Surdos precisa ser diferenciada para um modelo em que se dá maior valor ao "sentido e não à forma da escrita do Surdo, pois este apresenta uma escrita incorreta aos padrões ortográficos, sintáticos e semânticos" (p. 41).

Já que avaliações escritas não são significativas para os alunos Surdos, o Professor optou por aplicar a atividade avaliativa da seguinte forma: fez esquemas na lousa, elaborando cadeias com nomes de seres vivos, e solicitou que os alunos os explicassem em Libras, avaliando também a apropriação dos termos em português, uma vez que os alunos tinham que identificar palavras escritas e sinalizá-las. 
O foco na observação e análise das avaliações é perceber como os alunos representam as adaptações defensivas solicitadas após passarem por todos os conteúdos durante o semestre, percebendo quais tipos de sinais usam para essa representação e, a partir desse ponto, verificar a apropriação de conceitos científicos.

Registrei em diário de campo o primeiro dia de introdução às atividades avaliativas dos alunos. O Professor iniciou sua aula desenhando na lousa um leão, uma zebra e grama, mas salientou que, na avaliação final, não iria fazer desenhos, seriam só nomes. Com os desenhos, pediu aos alunos que soletrassem as palavras em português. O Professor apontou para o desenho da grama e pediu para um estudante digitar a palavra correspondente em português. O aluno fez: C-A-P-I-M, e registrou na lousa, depois pediu para outra aluna soletrar e ela fez M-A-T-O. Com as palavras escritas em português na lousa, o Professor pediu para os alunos fazerem os sinais correspondentes, apontou para a palavra mato e o aluno realizou o sinal de MORTE/ MORRER, não interpretando a palavra conforme o contexto. O Professor explicou que uma palavra pode ter diferentes significados, mas que os alunos precisavam se atentar e sinalizar de acordo com o contexto correto.

Em outro momento de aula, o Professor reforçou a diferença entre a explicação de uma cadeia alimentar em Libras e em português com o exemplo da lousa. Em português, a lógica da explicação segue de uma maneira, enquanto que, em Libras, segue de outra, como pode ser observado na figura 31:

Figura 31: Representação de qual deve ser o direcionamento das setas das cadeias alimentares quando se fala em Libras ou em português.

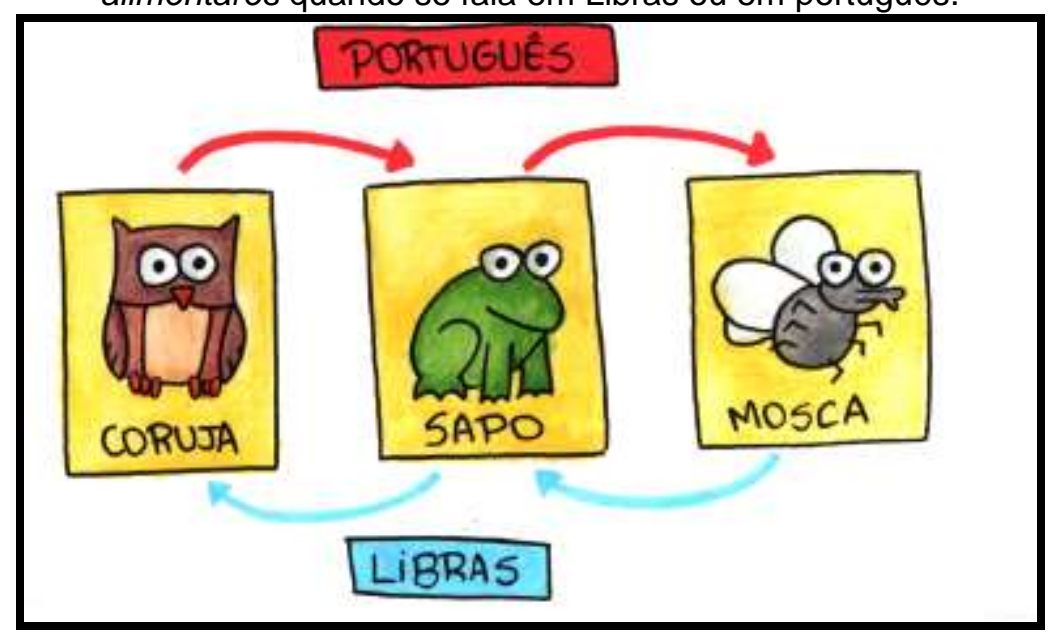

Fonte: Elaborada pela pesquisadora Beatriz Crittelli 
A figura 31 demonstra que, quando se explica em português, dizemos: "A coruja comeu o sapo que comeu a mosca" e isso é compreensível por conta da conjunção "que" e do verbo "comer" no passado, indicando que a coruja comeu o sapo e o sapo já havia comido a mosca. Mas quando se explica em Libras usando o mesmo direcionamento do português, a frase não faz sentido, porque a tradução direta resultaria em "CORUJA COMER SAPO COMER MOSCA", ou seja, a coruja come o sapo, o sapo come a mosca, mas como é possível o sapo que acabou de ser comido pela coruja realizar uma ação de comer uma mosca? Na Libras, não existem conjunções e preposições que podem auxiliar no sentido da frase, como a explicação em português, a ordem das frases, quando explicadas ou mesmo quando traduzidas, deve ser invertida para fazer sentido de acordo com a gramática da língua de sinais.

Assim, a frase em Libras deve se ater primeiramente ao consumidor primário ou ao produtor e, a partir deles, representar os outros animais que se alimentam deles. Como exemplo, a frase em Libras resultaria: "MOSCA SAPO COMER, SAPO CORUJA COMER", sempre utilizando classificadores para representar a cena e facilitar o entendimento dos alunos.

Um ponto a destacar na ordem das explicações: por mais que a lógica da explicação em português siga, no caso, do consumidor terciário para o secundário e depois o primário, os modelos de representação de cadeia alimentar possuem setas no mesmo direcionamento da ordem de explicação em Libras. Isso se dá porque as setas representam a passagem de energia de um nível trófico ao outro, podendo, assim, facilitar a compreensão dos alunos Surdos também por esse aspecto.

Durante a explicação da avaliação, o Professor discutiu com a classe o conceito de presa e predador e qual seria o sinal mais adequado para isso. A partir das discussões, os sinais combinados foram (Figura 32): 
Figura 32: Sinal de PRESA (sinal composto, com a mão dominante, palma aberta e dedos unidos, fazer sinal indicando a outra mão. O outro sinal segue com a configuração da mão dominante em letra "B" fazendo um movimento reto no pescoço de um lado para o outro) e PREDADOR (sinal composto, com a mão dominante, palma aberta e dedos unidos, fazer sinal indicando a outra mão. O outro sinal segue com a mão semi-dobrada e depois fechando frente à boca) combinado entre o Professor de ciências e os estudantes do sétimo ano "C".
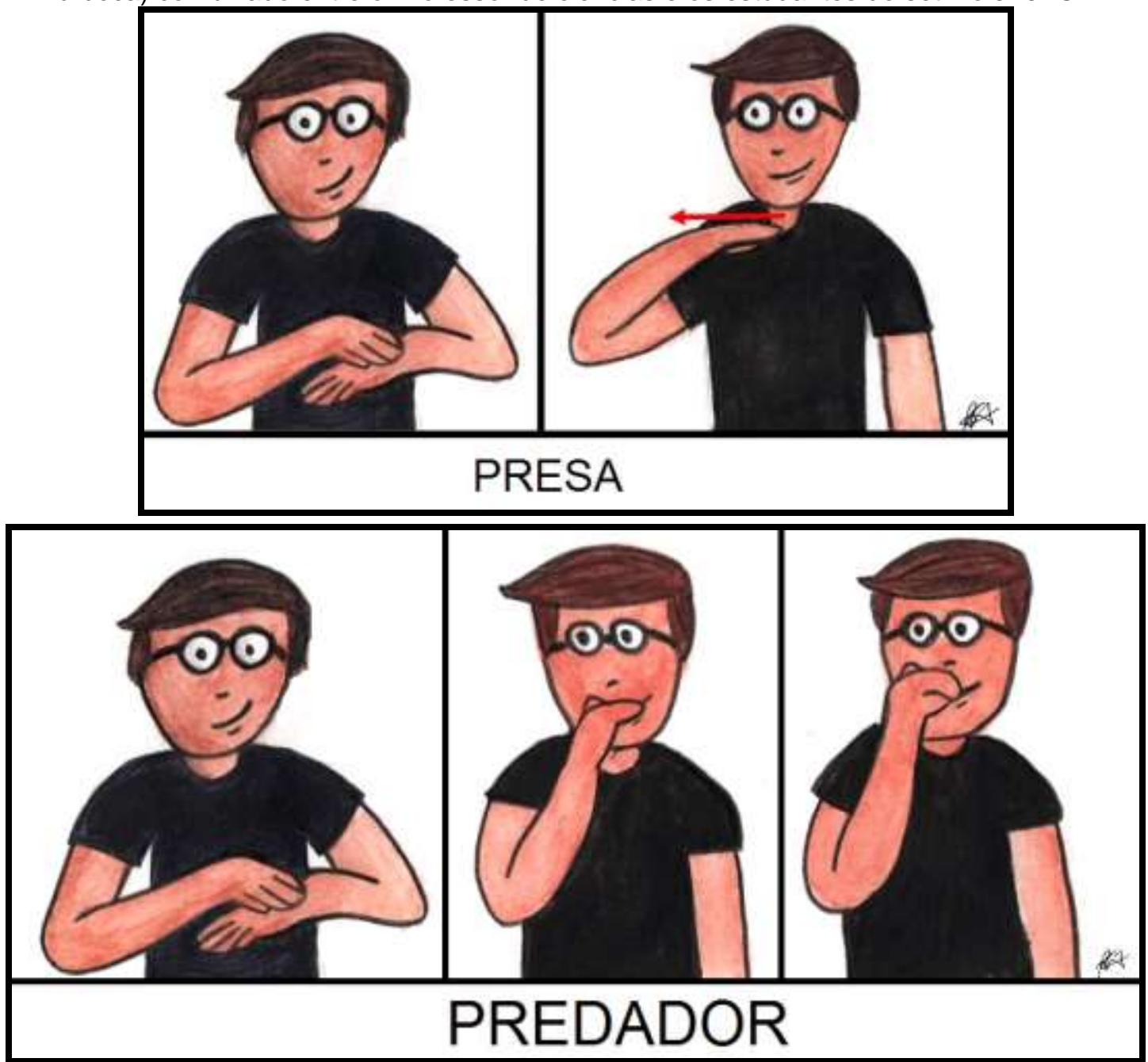

Fonte: Elaborada pela pesquisadora Beatriz Crittelli

O sinal de PRESA ficou combinado como um sinal composto, indicando a mão esquerda como um alvo junto do sinal MORRER, já o sinal de PREDADOR, também um sinal composto, indicando o alvo e depois executando o sinal COMER.

Os cinco registros em vídeos utilizados para a análise correspondem às avaliações dos seguintes alunos: Julia, Bruno, João, Daniel e Felipe ${ }^{7}$. Para facilitar a compreensão da análise das avaliações, cada aluno foi separado por quadros como segue a seguir:

\footnotetext{
${ }^{7} \mathrm{O}$ nome dos alunos foi alterado para preservar suas identidades.
} 


Julia
A aluna fez os sinais dos animais de forma correta, utilizando um
classificador para representar a cobra.
Na segunda etapa da atividade, quando ela deveria representar o sinal
de presa e predador de acordo com os animais escolhidos pelo Professor, no
caso, cobra e coruja, a aluna explicou o conceito de uma maneira diferente do
combinado até então em sala. Ela representou a mão direita sendo a cobra e a
mão esquerda como a coruja, e sinalizou a mão direita atacando a esquerda,
explicando, assim, quem seria a presa, no caso, a coruja, e quem seria o
predador, a cobra.
Quando o Professor aponta na lousa as palavras presa e predador, a
aluna se mostrou confusa, por já ter explicado essa relação. O Professor,
então, pede para ela fazer o sinal combinado com a sala para cada termo,
apontando para o animal, e a aluna, por fim, faz a associação dos termos com
os animais de acordo com as expectativas do Professor.
Em outra etapa da prova, o Professor selecionou a cadeia "cobra $\rightarrow$
sapo $\rightarrow$ mariposa" e pede à aluna para explicar a cadeia. Ela sinaliza
conforme a ordem do português, iniciando a explicação a partir da cobra,
deixando a explicação de forma linear e não espacial. Quando o Professor
exclui o sapo da cadeia e a indaga sobre o que acontece, a aluna responde
que o sapo morre e não desenvolve nenhuma justificativa quanto a isso.
Na última etapa da avaliação, o Professor destaca a cadeia "aranha $\rightarrow$
mariposa $\rightarrow$ planta" e risca a planta para questioná-la sobre o que pode
ocorrer com essa cadeia ao se extinguir esse organismo. A aluna diz que a
mariposa irá passar fome e a aranha morrerá, sem desenvolver a explicação,
finalizando, então, neste ponto.

\section{Bruno}

Bruno é um estudante que possui deficiência motora no corpo todo, porém, embora com movimentos comprometidos, todos os membros são funcionais.

Na primeira parte da avaliação, o aluno apresentou os nomes de todos 
os animais de forma correta, seguindo, assim, para a próxima etapa.

O Professor seleciona o papagaio e a aranha para trabalhar o conceito de presa e predador, e o estudante faz a seguinte explicação: "PRIMEIRO PAPAGAIO PEGA PARA COMER ARANHA/ ARANHA MORREU" explicando de uma maneira diferente à combinada com a sala, não realizando os sinais específicos e nem classificadores. O Professor aponta, então, para as palavras na lousa e o estudante realiza, assim, de forma correta a associação que a presa é a aranha e o predador é o papagaio, fazendo, neste momento, os sinais combinados em aula.

Por fim, não fez nenhuma reflexão a respeito das últimas etapas da prova sobre a extinção de um animal e a extinção das plantas.

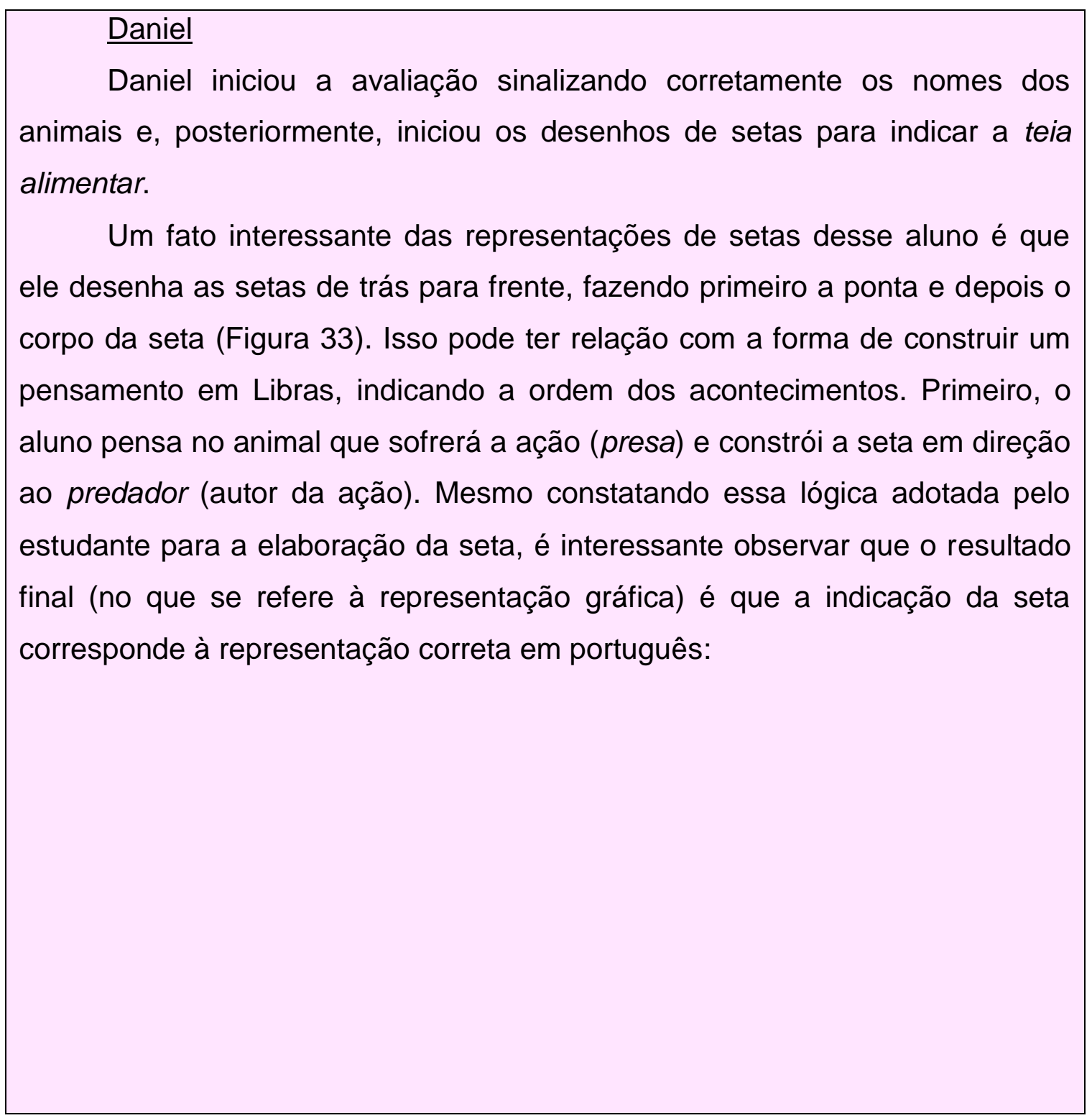


Figura 33: Representação do desenho de setas na teia alimentar elaborada pelo aluno Daniel.

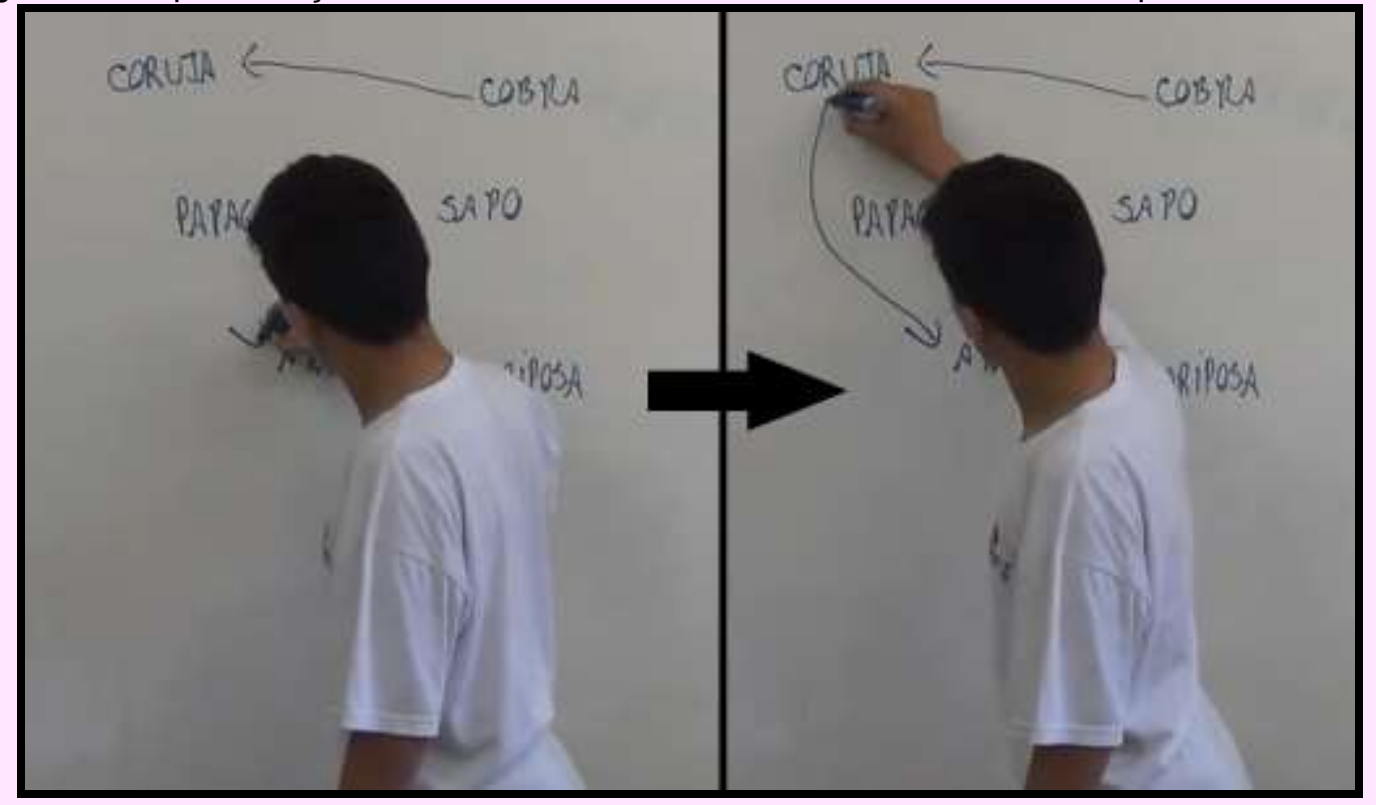

Fonte: Imagem elaborada pela pesquisadora Beatriz Crittelli a partir dos vídeos das avaliações.

Esse padrão de desenho de setas se alterou até o final da teia alimentar, o aluno desenhou os últimos animais da maneira padrão, corpo e depois a ponta.

Enquanto o Professor passava orientações para a sala, o aluno continuou observando o desenho de sua teia alimentar, até que se atentou para o fato de que havia se esquecido de incorporar as plantas em seu esquema, pediu o pincel atômico ao Professor e completou seu desenho.

O Professor selecionou a cobra e o sapo e indagou quem seria a presa e quem seria o predador. O aluno explicou o processo, indicando com a mão esquerda o sapo e com a mão direita a cobra, mostrando a cobra observando e atacando o sapo com a mão direita envolvendo a mão esquerda. 0 Professor apontou para as palavras presa e predador e o aluno representou com os sinais combinados em sala, mas não indicou os animais. O Professor perguntou novamente, indicando a palavra presa, o aluno respondeu com o sinal de SAPO e predador o aluno sinalizou COBRA.

Posteriormente, o Professor selecionou a cadeia "cobra $\rightarrow$ sapo $\rightarrow$ mariposa" e pediu ao aluno para explicar quem se alimenta de quem. O aluno representou a explicação conforme a estrutura da língua de sinais: indicou primeiro a mariposa e o sapo a atacando e depois indicou novamente o sapo e 
a cobra atacando.

A cobra foi cortada da cadeia, o Professor explicou em Libras que ela se extinguiu no mundo e escreveu ao lado da palavra "cobra" a palavra "extinto", perguntando ao aluno o que aconteceu com isso. O aluno respondeu que aumentou a quantidade de sapos de forma bem objetiva.

Depois, as plantas foram cortadas da mesma maneira que a cobra, escrevendo ao lado a palavra "extinto", e destacou-se a cadeia "aranha $\rightarrow$ mariposa $\rightarrow$ plantas" perguntando o que acontece, no futuro, com as mariposas e a aranha. O aluno indica que a mariposa morreu e o Professor indica que não é com um indivíduo e sim com um grupo. O aluno explica que as mariposas ficariam com fome e depois morreriam, mas não fala das aranhas. O Professor pergunta o que aconteceria com as aranhas, pois faltou esse dado em sua explicação, e o aluno responde que elas também morreriam porque faltariam borboletas para comerem.

\section{$\underline{\text { João }}$}

O Professor inicia sua explicação perguntando ao aluno o sinal dos animais, mas o aluno o interrompe se apresentando primeiro com seu nome e sinal. O aluno realiza os sinais corretamente e se preocupa em sinalizar de frente para o vídeo para que seus sinais fiquem bem visíveis.

O Professor seleciona "cobra $\rightarrow$ papagaio" e pergunta sobre a relação de presa e predador. De prontidão, o aluno responde indicando os sinais combinados com a sala, cobra (presa) e papagaio (predador). O Professor pede ao aluno para que explique melhor, pois ele só indicou quem era presa e quem era predador e, neste momento, o aluno posiciona a mão frente à palavra cobra e faz o sinal de ATACAR, frente à palavra papagaio. $O$ Professor novamente pede uma explicação sobre o processo e o aluno faz o papagaio em uma mão, fez o sinal combinado para presa, fez o sinal de cobra em outra mão, sinal de predador, e finalizou a explicação indicando a cobra atacando o papagaio.

A cadeia "cobra $\rightarrow$ coruja $\rightarrow$ sapo" foi selecionada e o aluno a explicou conforme a estrutura da língua de sinais, indicando o sapo, a coruja e a coruja atacando o sapo, e, depois, indicou a coruja, a cobra e a cobra atacando a 
coruja. O aluno representava os indivíduos com o indicador esticado, diferente dos outros alunos, que representavam com a mão estendida.

Na última etapa da avaliação, em que o Professor extingue a planta, o aluno indica que as mariposas ficariam com fome por faltar alimento para elas, assim, no futuro, elas morreriam. Já com relação ao grupo de aranhas, o aluno indicou somente que elas se alimentariam das mariposas, não indicando o desequilíbrio ecológico que ocorreria.

\section{Felipe}

O aluno inicia indicando os sinais de animais corretamente, porém ele sinaliza a cobra de acordo com o classificador e não o sinal exato e diz que se esqueceu do sinal de mariposa.

Quando o aluno começa a desenhar com setas a teia alimentar, ele mostra dúvidas sobre qual animal se alimenta de qual. Ele fica parado, olhando a lousa e indicando dúvida em como representar a seta. O aluno fez a representação da teia com a cobra como predador e todos os outros animais como presa, a única relação entre presa e predador que representou além dessa foi "papagaio $\rightarrow$ mariposa", excluindo as plantas da teia.

O Professor seleciona "cobra $\rightarrow$ sapo" e pergunta quem seria o predador, o aluno faz o sinal de atacar na mão, sem indicar os animais, o Professor retoma a pergunta e o aluno indica com a mão frente à palavra cobra o sinal ATACAR, direcionando a mão à palavra sapo. O Professor pergunta novamente quem seria a presa e o aluno indica que é a cobra, fazendo um sinal diferente do combinado, indicando a mão esquerda e o sinal de ATACAR nela, e predador indicando a mão direita e o sinal de ATACAR na mão esquerda.

Em outra etapa da avaliação, o Professor seleciona a cadeia "sapo $\rightarrow$ aranha $\rightarrow$ mariposa" e pergunta a relação entre esses animais. O aluno explicou como segue o padrão de explicação em português, sapo ataca a aranha que ataca a mariposa, sem fazer os sinais dos animais, e sim com a mão à frente dos nomes escritos. O Professor pede para retomar a explicação e o aluno representou os sinais dos animais, menos o da mariposa, do qual havia se esquecido, e explica novamente conforme o padrão da língua 
portuguesa.

A partir da mesma cadeia, o Professor retirou o sapo e indicou com a palavra em português escrita "extinto", explicando o que ocorreu e perguntando o que acontece no futuro com as aranhas. $O$ aluno diz que as aranhas se alimentariam das mariposas, mas o Professor retoma a pergunta e o aluno diz não saber o que aconteceria no futuro com as aranhas.

O Professor seleciona a cadeia "aranha $\rightarrow$ mariposa $\rightarrow$ plantas", mesmo sem o aluno ter incluído as plantas em sua teia, e pergunta o que ocorreria se as plantas se extinguissem, o aluno mostra que as aranhas comeriam as mariposas, mas que não haveria plantas. O Professor retoma a pergunta e o aluno indica não saber o que acontecerá.

Em uma visão geral da prova, os alunos usaram poucos classificadores para representar os processos de predadorismo dentro da teia alimentar. Esperava-se que eles utilizassem mais classificadores nas explicações porque esse é um tipo de representação que revela apropriação que o aluno faz da Libras e dos conteúdos trabalhados. Como exemplo com o uso de classificadores, o aluno indica como o animal anda, voa, ou rasteja e como ele ataca a presa.

Os classificadores apareciam para representar um animal caminhando, rastejando ou voando, e não para expressar um ataque de um para o outro. Como exemplo, a representação da frase "a coruja se alimentou do sapo", com os classificadores, seria feita com o sapo pulando, a coruja voando observa o sapo, voa em direção a ele e o captura com suas garras. Classificadores fazem parte da Libras e, no contexto científico, fazem parte da construção das representações dos processos científicos, interferindo em como o aluno compreende aquele processo.

Os sinais combinados com a sala também foram pouco utilizados na avaliação. Enquanto a língua portuguesa tem a necessidade de palavras específicas que representem um processo, na Libras, um sinal somente não possui o mesmo significado.

Por exemplo, os sinais de presa e predador. Isoladamente, cada sinal foi combinado com a sala toda e foi escolhido para ser aplicado nesse contexto, mas, durante a avaliação, não foi o que aconteceu. Os alunos só utilizavam os 
sinais específicos quando indagados "quem é presa? " e "quem é o predador?", mas, nas explicações, esses sinais eram substituídos pelo sinal ATACAR, indicando na lousa ou na própria mão quem atacava e quem era atacado.

\subsection{Vocabulário científico em Libras}

Ao acompanhar as aulas do Professor de Ciências, resolvi observar como o Professor trabalhava o desenvolvimento de conteúdos científicos mesmo sem a existência de sinais em Libras correspondentes a alguns termos científicos relacionados aos conteúdos trabalhados.

Podemos encontrar dicionários em Libras apresentados em diferentes formatos de mídia, tais como: vídeos, dicionários impressos, imagem em movimento e, até mesmo, avatares ${ }^{8}$, mas a língua sofre muita influência de regionalismos e de diferentes meios de consulta e, por consequência, pode-se encontrar diferentes sinais para um mesmo termo.

Muitos termos científicos são expressados por professores e intérpretes através da datilologia da palavra em português. $O$ aluno Surdo, perante uma educação bilíngue, precisa ter o conhecimento dos termos em português, porém, ele também tem o direito de poder expressar tal termo em sua língua e, com a ampliação do vocabulário científico dentro da comunidade Surda, aos poucos a Libras vai alcançando esses espaços.

Um professor de ciências que trabalha com alunos Surdos não pode limitar suas aulas somente ao fato de o vocabulário científico não ser ainda amplo dentro da Libras. Ao contrário, deve desenvolver junto de seus alunos estratégias para poder aproximá-los desses conhecimentos e não os afastar.

Durante a entrevista com o Professor, levantei essa problemática com a finalidade de compreender como ele trabalhou em sala esses termos específicos. Ele explicou que sempre inicia seu trabalho a partir das

\footnotetext{
${ }^{8}$ Avatares são animações gráficas que representam pessoas e seguem comandos estipulados pelos indivíduos que os manipulam. Como exemplo, os dois principais Avatares, hoje, (Hand Talk e ProDeaf) podem ser obtidos de forma gratuita em aplicativos para celular e outros eletrônicos.
} 
concepções prévias dos alunos, conforme podemos ver na transcrição de sua fala:

\begin{abstract}
Então a ideia foi a partir da camuflagem e do mimetismo. Eu apresentei algumas sequências de imagens aleatoriamente organizadas, e então, a partir dessas imagens, a gente começou a construir alguns sinais. Eu perguntava para eles: "isso aqui, o que está acontecendo com o animal?" Apresentando uma foto relacionada com a camuflagem, "e nessa aqui?" Aí apresentava uma foto relacionada ao mimetismo, e nisso estava estabelecendo alguma relação com eles com a intenção de perceber quais sinais que eles associavam com cada uma das situações (transcrição literal retirada da entrevista com o Professor de ciências).
\end{abstract}

A partir da explicação do que ocorre no processo de escolha de um sinal adequado para o termo científico estudado é que o Professor constrói os sinais em suas aulas. O Professor chama esse processo de combinar sinais com os estudantes. Ele comentou, ao longo da entrevista, que faz consulta a dicionários estrangeiros em língua de sinais, porém, neste caso, ele não adotou nenhum sinal deles para suas explicações.

Em certo momento da entrevista, o Professor descreveu como ocorre o processo de construção de sinais com o exemplo do aposematismo:

\begin{abstract}
Coloca uma cobra lá, aí fala, "o que vocês pensam a respeito da cobra? Quando vocês veem uma cobra o que vocês sentem, por que que vocês sentem isso? Está relacionado com o quê, né?" Aí eles vão colocando essas coisas para fora, e aí algumas coisas que fazem vocês sentirem isso, aí vocês vão perguntando esses tipos de coisa e de repente vão surgindo elementos para vocês irem falando, são referenciais que são importantes para eles pensarem os significados que essas cores têm nesse organismo, através desse questionamento, desse diálogo frequente que eles têm em sala de aula (transcrição literal retirada da entrevista com o Professor de ciências).
\end{abstract}

Questionei o Professor se esse processo de combinar sinais é feito em cada uma das salas. Havia quatro salas de sétimo ano e, nesse caso, surgiram, ao longo das aulas, sinais diferentes para o mesmo processo em cada sala. Com essa pergunta, o Professor indicou inicialmente que ele se preocupa com a comunicação dos alunos com os colegas de outras turmas, então, é necessário chegar a um padrão de sinais entre as salas.

Os estudantes chegaram à conclusão de que, para camuflagem, os seres vivos se escondem no ambiente, combinando então o sinal ESCONDER. 
Para mimetismo, os animais se parecem com outro que possui veneno, combinando o sinal PARECER no sentido comparativo. Por fim, para aposematismo, os animais possuem cores que indicam veneno, combinando $o$ sinal COR+VENENO. Com isso, nas aulas seguintes, o Professor utilizou os sinais representando esses conceitos (vide Figura 14).

Esses três termos não se encontram em dicionários de Libras., Por isso, sem perceber que esse trabalho de ensino/aprendizagem não se limita a palavras científicas correspondentes na Libras, mas também se preocupou em saber como eram trabalhados esses conteúdos, me questionava: "como o Professor conseguirá trabalhar esses conteúdos se a Libras não possui sinais específicos?"

O Professor avaliava se os estudantes correspondiam de forma correta ou não com os sinais criados a partir de atividades escritas e filmadas. Durante a aula, alguns alunos traduziam suas frases escritas para o Professor, indicando outra palavra em português correspondente ao sinal de Libras, ou outro sinal de Libras correspondente às palavras em português. Por exemplo, no caso do mimetismo, alguns alunos utilizavam o sinal representado na Figura 34, que significa, em português, "eu acho" ou "me parece que..." e não o sinal combinado de PARECER no sentido de comparação entre dois organismos. Nesse momento, o Professor corrigiu, indicando, para esse contexto, qual seria o termo mais adequado. 
Figura 34: Representação comparativa entre os sinais PARECER (dedo polegar, indicador e médio esticados, orientação da palma da mão para dentro, posicionar o indicador e o dedo médio com o nariz no meio e, em movimento retilíneo, levar a mão frente ao rosto, mantendo a mesma configuração de mãos) utilizados pelos alunos em sala de aula com o sinal de MIMETISMO.
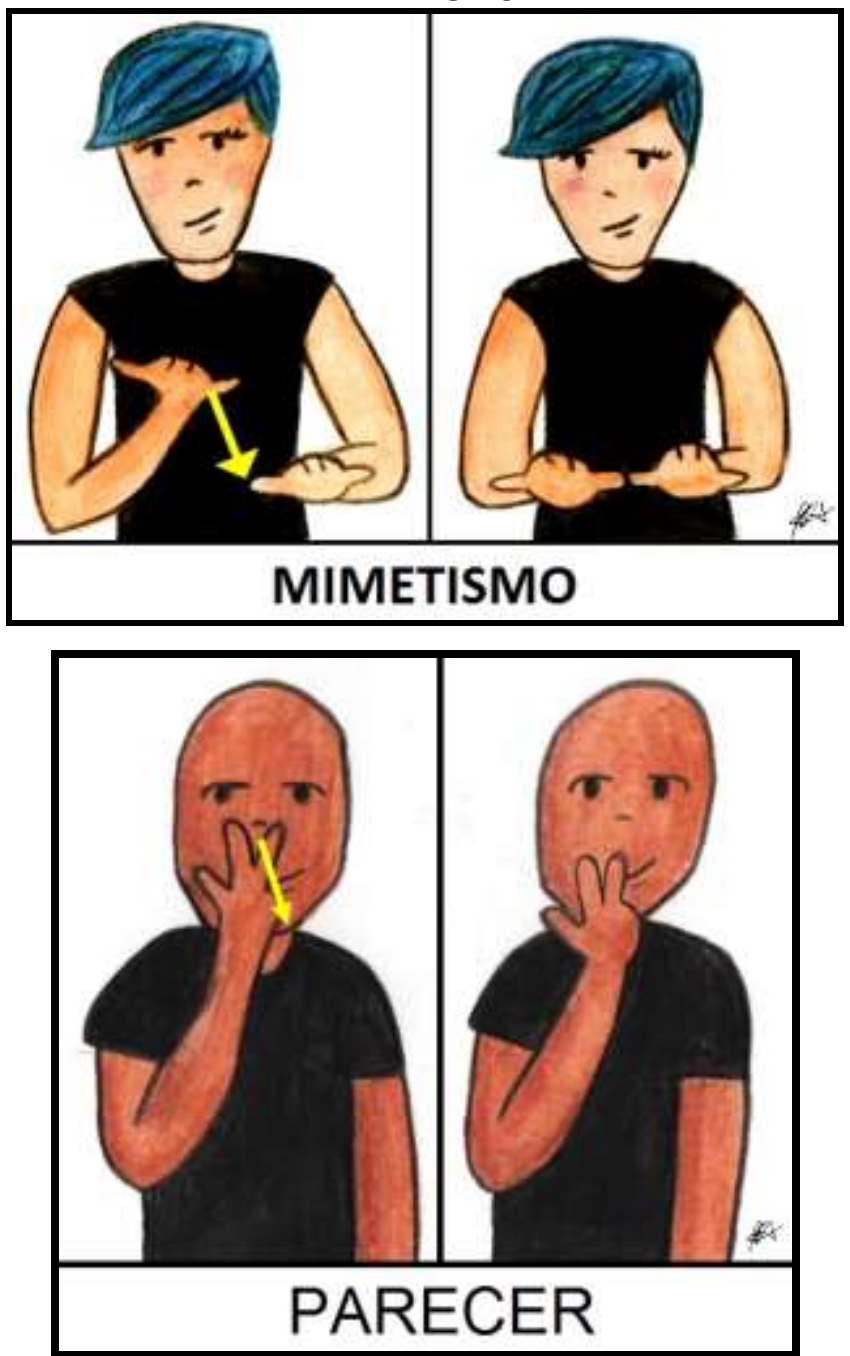

Fonte: Elaborada pela pesquisadora Beatriz Crittelli

Pelo significado, o primeiro sinal representado na figura acima é o mais indicado para representar o conceito de mimetismo.

Outra situação recorrente era a expressão das palavras em português que os alunos escreviam para os sinais combinados. Algumas vezes, eles escreviam ou soletravam palavras semelhantes em português, mas não correspondentes. Um exemplo de situação: enquanto uma aluna desenhava uma rã com cores bem chamativas, o Professor perguntou a ela se, na adaptação defensiva que realizava, o animal que escolheu estava fazendo camuflagem, mimetismo ou aposematismo. Ela respondeu aposematismo, através do sinal combinado com a sala, e perguntou aos colegas como se 
escreve essa palavra em português, pedindo para fazerem a datilologia. Um aluno se levantou e respondeu a ela, fazendo a datilologia: V-E-N-E-N-O-S-O, pois associou o significado do sinal e não ao sinal combinado pela sala, desconsiderando que a combinação de COR+VENENO significava a palavra, em português, aposematismo.

Seguindo a mesma didática, o Professor iniciou as explicações do novo conteúdo a partir do conhecimento prévio que os estudantes possuíam em relação aos animais. Dessa forma, o docente estabeleceu uma relação alimentar entre eles e, assim, os alunos puderam perceber como ocorre, no ambiente, essas interações de uma maneira geral e não particular. O conceito de cadeia alimentar foi trabalhado selecionando-se partes da teia, possibilitando, assim, que, em todo o tempo, os estudantes vissem o processo de uma forma ampla e, a partir disso, especificassem. Em Libras, não houve diferenciação entre os termos cadeia alimentar e teia alimentar, o sinal utilizado está representado na Figura 35, indicando o verbo "atacar" e, a partir dele, um ser se alimentando de outro, propiciando uma ideia tridimensional de todo 0 processo:

Figura 35: Sinal de TEIA ALIMENTAR (configuração de mãos em letra "C", orientação da palma da mão para baixo, com a mão dominante, fazendo movimento semicircular até o antebraço.

Repetir o movimento com a outra mão) realizado pelo Professor durante suas aulas.

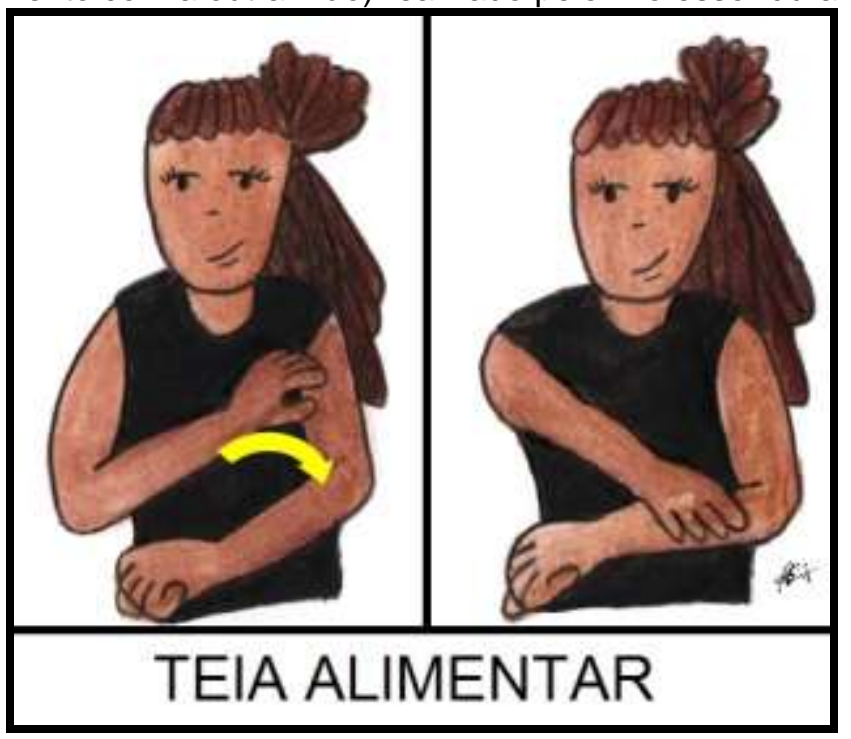

Fonte: Imagem elaborada pela pesquisadora Beatriz Crittelli

Para as explicações das relações entre presa e predador, o Professor representava com histórias e explicações com um animal se alimentando de 
outro, representando com uma mão a presa e com outra o predador e, com isso, uma mão atacando a outra. Durante as aulas, um aluno levantou a questão: "presa o animal morreu, predador o animal comeu". Com isso, combinou-se com as salas que o sinal representando presa seria indicação da mão esquerda em conjunto ao sinal MORRER, enquanto que o sinal de predador seria a indicação da mão esquerda em conjunto ao sinal COMER.

Durante as aulas e avaliações dos alunos, o sinal de cadeia alimentar foi pouco representado, surgindo mais nas perguntas do próprio Professor. Com os sinais de presa e predador, houve com frequência a representação desse processo com a representação de cada animal com a mão direita e outro com a mão esquerda e, com isso, uma mão "atacando" a outra. O sinal combinado com a sala surgia quando o Professor indagava os alunos sobre o sinal, apontando para a palavra. Outra representação frequente foi somente com 0 sinal de ATACAR, feito com a mão frente às palavras referentes aos animais.

Retomando os conceitos de Vigotski (1988), a relação entre o pensamento e a linguagem é um processo que se dá do pensamento à palavra, e, por sua vez, da palavra ao pensamento, mudando a função primária da linguagem na medida em que aumenta a experiência educacional da pessoa. No caso, essas palavras são consideradas sinais e, além dos sinais, classificadores que correspondem aos conceitos científicos estudados, desenvolvendo, assim, um pensamento científico no aluno Surdo.

A respeito da necessidade de sinais referentes a termos específicos de ciências, acredita-se que tal ausência pode levar a uma criação controversa de um sinal relacionado a um conceito científico, podendo-se, para um mesmo conceito científico, ser encontrada uma variedade de sinais, permitindo, inclusive, distorções e interpretações equivocadas sobre esses conceitos (ALVES; PEIXOTO; LIPPE, 2013). Essas observações nos permitem refletir acerca do papel do Professor referente à escolha dos sinais específicos para utilizar em aula e, no caso, constatou-se que a decisão do Professor foi combinar os sinais com os alunos para que eles fizessem parte da construção dos conceitos trabalhados em aula.

Alguns autores apontam que a Libras deve ter um maior aprofundamento científico e criar dicionários mais complexos para a divulgação dos sinais (ALVES; PEIXOTO; LIPPE, 2013), juntamente com uma formação 
mais ampla dos intérpretes e melhor preparação dos professores. Porém, Lacerda (2011) aponta que, mesmo vencendo as barreiras de comunicação, existe um outro importante obstáculo, que é a adequação de metodologia e currículo para o estudante Surdo.

De acordo com Campello (2008), para a construção de conceitos para alunos Surdos, no caso conceitos científicos, é necessário o uso de recursos visuais e, principalmente, de classificadores. A autora afirma:

\begin{abstract}
Todo e qualquer recurso que for utilizado para ajudar na comunicação, a compreensão dos conceitos deverá ser aplicada com naturalidade, e não para modificá-los, mas para auxiliar na compreensão e tradução gramatical visual. As técnicas, recursos e perspectivas utilizados na pedagogia visual, estão relacionados com o uso da "visão", em vez da "audição", sendo que a imagem na "apreensão do estímulo visual" e perspectiva emergem de acordo com forças bidimensionais e tridimensionais. Esses processos exigem uma nova forma de pensar o nível perceptivo e o processamento visual daquilo que rodeia o sujeito Surdo e qual seu olhar sobre 0 mundo no processo de ensinar e aprender (CAMPELLO, 2008, p. 209).
\end{abstract}

Seguindo esse pensamento, os classificadores são necessários para auxiliar na compreensão dos conceitos científicos e dos conteúdos a serem estudados, pois, na representação por classificadores, está todo o conteúdo científico que envolve tal processo.

Sinais específicos criados para corresponderem a conceitos científicos são necessários também porque, na medida em que a língua se desenvolve, precisa adquirir vocabulário para as diversas áreas do conhecimento. Mas, muitas vezes, a própria Libras, através dos classificadores, consegue representar um conceito científico. Então, antes de se deparar com um conceito científico e perceber que não há sinal correspondente, é importante verificar se esse conceito pode ser explicado com classificadores, se não, deve-se ir atrás para a criação e validação de um novo sinal.

Sintetizando o que observei durante as aulas a respeito do vocabulário científico, o Professor introduziu diversos conteúdos dentro de um tema principal. Deparou-se com conceitos para os quais não havia sinal específico e, diante disso, fez pesquisas, constatando realmente que não havia sinais específicos para determinados termos. O Professor optou, então, por combinar os sinais com a sala, com as propostas de sinais partindo dos próprios alunos. 
Dos sinais combinados, destacam-se: camuflagem, mimetismo, aposematismo, presa, predador e teia alimentar.

Diante desses sinais combinados, os sinais para camuflagem, mimetismo e aposematismo resultaram em uma combinação de sinais já existentes: ESCONDER, PARECER, COR+VENENO. Os sinais de presa, predador foram junções de sinais existentes com adaptações, indicando, na mão, o alvo e associando com o sinal MORRER ou COMER. O único sinal criado sem associações com outros já existentes foi o de teia alimentar, porém, o sinal carrega uma adaptação do sinal COMER, direcionado aos braços, formando uma "teia".

Mesmo perante esses sinais combinados com a sala, durante a avaliação final, os alunos incorporaram os sinais de camuflagem, mimetismo, aposematismo e teia alimentar. No entanto, em relação aos sinais de presa e predador, estes foram explicados de outras formas pelos alunos, sem que se usassem esses sinais combinados. Os estudantes utilizaram, também, classificadores, mas para mostrar o animal andando, voando ou rastejando, não para explicar os conceitos trabalhados em sala.

Tal fato revela que, para o entendimento dos conceitos envolvendo predadorismo, os alunos não incorporaram os sinais criados por eles próprios, pois a própria língua, com seus elementos, consegue explicar esse conceito sem a necessidade de haver um sinal específico para determinado conteúdo.

Concluo, de acordo com este relato, que é importante haver uma preocupação em relação à Libras se expandir para um vocabulário científico, mas que, antes de propor que novos sinais sejam criados, é necessário que se faça uma boa análise com os Surdos para verificar se a própria língua já consegue explicar e aprofundar os conceitos utilizando seus elementos, como por exemplo, classificadores.

Afirmo também a importância que um bom planejamento da prática pedagógica pode trazer para o ensino, como pôde ser observado nas aulas do Professor, que cada conceito trabalhado em aula, além de utilizar modalidades didáticas diferentes, refletiu em aulas diferenciadas, possibilitando aos alunos perceber o quanto que os conteúdos estavam interligados. 

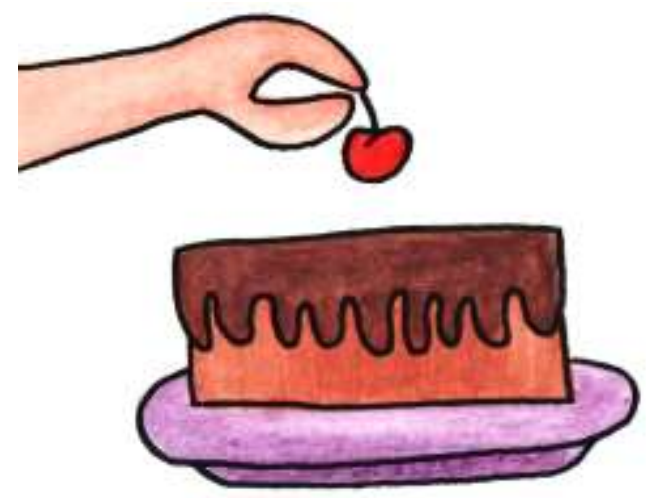

\section{CONSIDERAÇÕES FINAIS}

A Libras se configura a partir de uma maneira diferente de raciocinar em relação ao português. Enquanto esta língua mantém um pensamento linear, a Libras se configura espacialmente e tal diferença pôde ser observada nas representações escritas dos estudantes Surdos, porém, nas avaliações finais, os conceitos foram representados seguindo a estrutura da Libras.

No contexto de trabalho bilíngue, em que ocorrem muitas dimensões de aprendizado ao mesmo tempo, com a apropriação da Libras realizada com os alunos Surdos nos anos iniciais, a língua portuguesa não pode ser totalmente desconsiderada, mas deve ser trabalhada em sua modalidade de leitura (não oralizada) e escrita. Com os termos científicos, algumas opções podem ser levadas em consideração, tais como: o professor trabalhar o conceito $\mathrm{e}$ representar os processos espacialmente, ou também com os sinais combinados, e, a partir do sinal, introduzir em lousa o nome correspondente em português, trabalhar com esses mesmos nomes em atividades para que 0 aluno consiga fixá-los e, além disso, envolvê-los em atividades avaliativas.

Dentre as metodologias para o ensino de ciências, temos: uso de recursos didáticos; idas ao campo e a espaços de educação não formal; ensino 
por investigação; experimentos, entre outras, mas ao ter como foco o trabalho com o aluno Surdo, cabe antes um estudo de quais metodologias seriam as mais adequadas para aquela determinada aula, levando-se em consideração a Libras e também o português.

Outra preocupação quanto às diferentes estratégias metodológicas refere-se às adaptações necessárias para elas serem aplicadas adequadamente ao aluno Surdo. Por exemplo: se o professor propõe a utilização de um vídeo, deve ser criterioso ao escolher um material cujas informações não dependam do áudio e, também, que não dependam de legenda. Pelo fato de as legendas se restringirem a explicações na língua portuguesa, as imagens ali representadas devem ser explícitas e autoexplicativas, ou o professor pode ir passando o vídeo com interrupções para explicar, em Libras, o que quer destacar.

Se um professor planeja suas aulas em seus aspectos conceituais e metodológicos aplicados apenas a alunos ouvintes e entra um aluno Surdo em sua sala, todo seu planejamento deverá ser repensado. Mas, se essas aulas já forem planejadas de acordo com as particularidades que envolvam o ensino de Surdos, consequentemente os alunos ouvintes já serão inclusos nessas aulas e, possivelmente, beneficiados com as diferentes metodologias trazidas para se trabalhar os conteúdos com todos.

A visão de que a Libras é uma língua imatura não considera que essa é uma língua recentemente reconhecida no país, na última década, através de uma lei e que, por muitos anos, foi proibida de ser utilizada pela comunidade Surda. Na medida em que as pessoas Surdas vão ocupando os espaços, principalmente os espaços educacionais e acadêmicos, essa língua vai crescendo junto com a comunidade e seus falantes.

Vale ressaltar que toda essa reflexão final tem como o foco a educação bilíngue de Surdos e não as escolas comuns, em que o aluno Surdo é um aluno de inclusão, nesse contexto, o processo de significação é outro. A análise deste trabalho foi realizada dentro de um contexto de aulas ministradas inteiramente em Libras para alunos Surdos e aulas em português para alunos ouvintes.

Um professor de ciências de alunos Surdos não deveria limitar suas aulas somente ao fato de o vocabulário científico não ser ainda amplo dentro 
da Libras. Uma opção seria desenvolver, junto de seus alunos, estratégias para aproximá-los desses conhecimentos, e não os afastar.

Classificadores podem ser usados como uma possível estratégia, pois, com eles, temos um elemento da Libras sendo utilizado para uma representação do conceito a ser estudado, muitas vezes não sendo necessário o uso de um sinal específico para expressar um conceito.

Com o presente estudo, pudemos constatar que o trabalho com 0 vocabulário científico é complexo, exigindo uma adequação metodológica e de construção de pensamento a partir da Libras, mas esse trabalho é, sim, possível.

Ao se comparar a Libras com o português, ter um sinal corresponde a uma palavra é diferente de ter uma ideia que corresponde a esse fenômeno. Entender como a linguagem científica se expressa, na Libras, nos faz pensar se as próprias palavras, em português, dão conta de trazer o significado que possuem. Por exemplo, quando um professor introduz uma aula sobre o tema artrópodes, pode trabalhar esse grupo de animais pelo significado que essa palavra carrega: "artro" significa articulação e "podes" pernas, portanto, os animais pertencentes a esse grupo possuem pernas articuladas, mas esse raciocínio é feito, e também é possível, em relação a todos os conceitos científicos que um professor trabalha em sala? No contexto de aula analisado, com as aulas em Libras, posso afirmar que sim.

Isso possibilita aos professores se defrontar com a apropriação geral de ensino de ciências, dá a oportunidade de pensar nas questões de linguagem que essa área abarca.

Quando se pensa em aulas de ciências para alunos ouvintes, encontramos diversos desafios de como se trabalhar os conceitos e linguagem científica com eles. Com os alunos Surdos, esse desafio também está presente, porém, a esse desafio são somadas as particularidades da língua de sinais que, a depender do professor, pode se agregar ricamente à construção de significados em conjunto com os alunos através da construção dos conceitos em aula.

Ao refletir sobre o ensino de Surdos, a depender da abordagem pedagógica utilizada, o vocabulário científico é parte final do processo de aprendizagem, assim como pôde ser constatado nas aulas analisadas. Por 
exemplo, no caso estudado, a introdução dos conteúdos se inicia com hipóteses, questionamentos e explicações dos processos e fenômenos observados e, somente ao final do estudo desse conteúdo, quando necessário, combina-se com a sala sinais que sintetizem e representem toda essa trajetória lógica. Já em outras abordagens pedagógicas, é de costume que as aulas sejam introduzidas através de palavras-chave e, a partir dessas palavras, os conteúdos são desenvolvidos.

Essa lógica de aula dos Surdos pode ser uma boa estratégia para ser aplicada nas aulas para os ouvintes. Como foi observado na pesquisa, combinar sinais é uma possibilidade de se trabalhar conceitos científicos em aula, mas é necessário ter rigor ao combiná-los, pois utilizar sinais existentes para representar conceitos científicos pode, algumas vezes, limitar o conceito científico a um termo específico, restringindo a amplitude de seu significado. Algumas vezes, a construção de sinais científicos com sinais compostos por dois sinais, ou mais, pode expressar melhor o fenômeno científico a ser representado, ao mesmo tempo em que é preciso ser cauteloso para o sinal não se tornar uma explicação do conteúdo.

O que, então, é necessário para se trabalhar no contexto de ensino de Surdos em escolas bilíngues é pesquisar sinais em diversas vias (comunidade Surda, dicionários, avatares, entre outros), comparar os sinais encontrados e ver a adequação científica, principalmente se representam plenamente os conceitos científicos e, por fim, verificar se aquele conceito científico pode ser plenamente expresso utilizando-se classificadores. De igual modo, deve-se averiguar se é realmente necessário que se combine com os alunos um sinal específico para aquele termo.

Nas aulas observadas, pôde-se perceber a negociação com os alunos para a construção dos sinais específicos e, mesmo com um consenso, alguns deles não utilizavam os sinais combinados tanto durante as aulas quanto nas avaliações finais. Tal fato pode indicar que, por mais que esse combinado tenha sido negociado com todos, alguns alunos revelaram ter incorporado melhor o conceito e formado o pensamento científico a respeito do fenômeno a partir de outro sinal ou mesmo utilizando classificadores.

Diante dos fatores apresentados, é necessária a reflexão acerca de quanto os ouvintes, sejam eles professores ou pesquisadores, tentam 
"fonologizar a Libras", ou seja, colocá-la dentro dos padrões da língua portuguesa até mesmo no ensino de outros conteúdos, como os científicos, exigindo o tempo todo sinais correspondentes a termos, sendo que, muitas vezes, elementos da Libras, como classificadores, dão conta de que tal conteúdo seja trabalhado sem a exata correspondência terminológica do português para a Libras. Para essa área, é necessário um estudo aprofundado de linguagem científica em Libras para que não haja uma imposição linguística e, consequentemente, cultural do português em detrimento da Libras.

Uma aula dada em português sinalizado, com a correspondência exata de "palavra-sinal" do português para a Libras, não é uma aula que está respeitando a estrutura da língua de sinais, a construção de significados com a língua de sinais e, principalmente, o processo de ensino e aprendizagem dos Surdos. Consequentemente, essa questão leva esses alunos a terem um ensino deficitário em termos de língua e conteúdo. Isso promove um retrocesso no ensino de Surdos, que passou do oralismo para a comunicação total e depois para o bilinguismo. Dessa maneira, o bilinguismo, além de não estar sendo trabalhado da maneira correta, está sofrendo uma imposição linguística da língua portuguesa, retornando, os alunos Surdos, a serem sujeitos "hemilíngues", sem o bom conhecimento da Libras nem do português.

Portanto, pode-se afirmar que o processo de criação de novos termos científicos, em Libras, é bastante complexo, exigindo do professor de ciências, ouvinte cuja língua materna é o português, um importante papel em escolher como vai conduzir essa construção do pensamento científico para os alunos Surdos, seja pedindo aos alunos para criar novos sinais, utilizar uma combinação de sinais existentes, classificadores, ou combinando sinais com a sala.

É importante ressaltar os impasses e possíveis práticas existentes no ensino de ciências para Surdos. Assim, será possível colaborar com futuras construções de saberes a fim de desenvolver essa área do conhecimento para aproximar cada vez mais as pessoas Surdas do conhecimento científico, e não os afastar ou excluir de um conhecimento que é direito de todos.

Finalizo o trabalho com a citação: "Falar e defender a diferença é fácil; o difícil é colocarmo-nos no lugar daquele que é diferente, reconhecendo-o em 
sua maneira de ser, distinta da nossa" (SOBRAL, 2010), assumindo que esse foi o meu maior desafio, neste trabalho, e é essa ideia que pretendo seguir nos próximos. Afirmo, também, que esse trabalho só se concretizou dessa maneira pelo fato de o Professor ter se posicionado dessa forma em suas aulas, se colocando no lugar dos alunos e possibilitando que eu pudesse constatar tudo o que descrevi nesta pesquisa. 


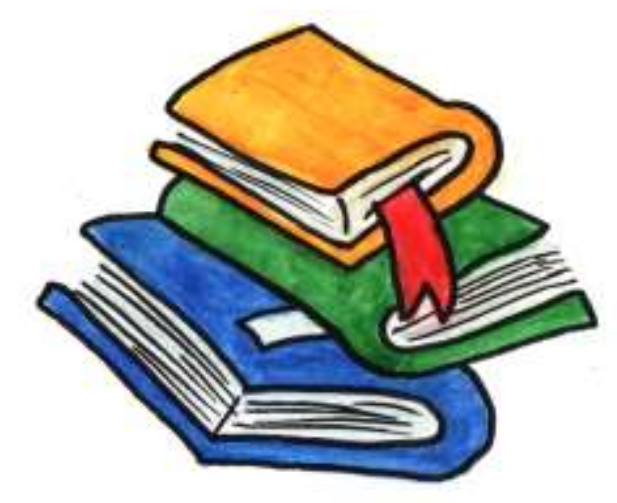

\section{REFERÊNCIAS BIBLIOGRÁFICAS}

ALBRES, N. A de. A educação de alunos Surdos no Brasil do final da década de 1970 a 2005: análise dos documentos referenciadores. Dissertação (mestrado), Universidade Federal de Mato Grosso do Sul, Centro de Ciências Humanas e Sociais, Campo Grande/MS, 2005.

ALBUQUERQUE, T. C. C. de; SÁ, R. G. B. de; CARNEIRO-LEÃO, A. M. A. dos. A importância da habilidade de leitura de imagens para a compreensão de conceitos científicos. Revista da SEnBio - número 7, V Enebio e II Erebio Regional 1, 2014.

ALMEIDA, T. J. B. de. Uma investigação sobre o papel do interlocutor de Libras como mediador em aulas de Física para alunos com Deficiência Auditiva. Dissertação (Mestrado)-Universidade Estadual Paulista. Faculdade de Ciências, Bauru, 2013.

ALMEIDA, M. P.; ALMEIDA, M. E. História da Libras: características e sua estrutura. Revista Philologus, Ano 18, № 54 - Suplemento: Anais da VII JNLFLP. Rio de Janeiro: CiFEFiL, 2012.

ALVES, F. S. de. Ensino de Física para pessoas surdas: o processo educacional do surdo no ensino médio e suas relações no ambiente 
escolar. Dissertação (Mestrado) - Universidade Estadual Paulista. Faculdade de Ciências, Bauru, 2010.

ALVES, F. S de; PEIXOTO, D. E.; LIPPE, E M. O. Releitura de Conceitos Relacionados à Astronomia Presentes nos Dicionários de Libras: Implicações para Interpretação/Tradução. Rev. Bras. Ed. Esp., Marília, v. 19, n. 4, p. 531-544, Out.-Dez, 2013.

ANDRÉ, M. E. D. A. de. Estudo de caso em pesquisa e avaliação educacional. Brasilia: Liber Livro, 2005. (Série pesquisa, 13).

ANDRÉ, M. E. D. A. de. Etnografia da prática escolar. Campinas: Papirus, 2008.

BARBOSA, R. "Projeto Geo-escola: recursos computacionais de apoio ao ensino de geociências nos níveis fundamental e médio". Dissertação (mestrado) Universidade Federal de Campinas, Instituto de Geociências, 2003.

BACHELARD, G. A formação do espírito científico. Rio de Janeiro: Contraponto, 1996.

BARGALLÓ, C. M. Aprender ciencias a través del lenguaje. Revista Educar, Espanha, Barcelona, abril-junho, 2005.

BENVENUTO, A. O surdo e o inaudito. À escuta de Michel Foucault. In: GONDRA, José KOHAN, Walter (orgs.), Foucault 80 anos. Belo Horizonte: Autêntica, (p. 227-246), 2006.

BÍBLIA. N. T. João. In: BÍBLIA. Português. Bíblia de estudo: contendo o antigo e o novo testamento. NVI (Nova Versão Internacional) - São Paulo: Editra Vida, 2003.

BERNARDINO, E. L. A. 0 uso de classificadores na língua de sinais brasileira. ReVEL, v. 10, n.19, 2012. Disponível em: <www.revel.inf.br>. Acesso em 15/01/2016.

BOBBIO, N. A Era dos direitos. Rio de Janeiro: Elsevier, 2004, 240 p.

BORDINHON, T. Fonologia da Libras: Parâmetros formacionais da língua brasileira de sinais. In: X Congresso de Educação do Norte Pioneiro Jacarezinho. 2010. Anais. UENP - Universidade Estadual do Norte do Paraná - Centro de Ciências Humanas e da Educação e Centro de Letras Comunicação e Artes. Jacarezinho, 2010. ISSN - 18083579. p. 333 - 351. 
BRASIL. Constituição da República Federativa do Brasil. Brasília: Imprensa Oficial, 1988.

Decreto de Lei n⒌626 de 22 de dezembro de 2005. Brasília: Presidência da República, Casa Civil, Subchefia para Assuntos Jurídicos, 2005.

Decreto de Lei no 57.379 de 13 de outubro de 2016. São Paulo: Secretaria Municipal de Educação, 2016.

Decreto de Lei no 7.387 de 9 de dezembro de 2010. Brasília: Presidência da República, Casa Civil, Subchefia para Assuntos Jurídicos, 2010. Lei de Diretrizes e Bases da Educação Nacional. Câmara dos Deputados, Brasília 2001.

Lei no 10.436, de 24 de abril de 2002. Dispõe sobre a Língua Brasileira de Sinais - Libras e dá outras providências. Diário Oficial da República Federativa do Brasil, Brasília, DF, 24 abr. 2002.

Lei no 13.146, de 6 de julho de 2015. Brasília: Presidência da República, Casa Civil, Subchefia para Assuntos Jurídicos, 2015.

PCN. Parâmetros Curriculares Nacionais. Secretaria de Educação . Brasília. MEC. 1999.

Política Nacional de Educação Especial na Perspectiva da Educação Inclusiva. Brasília: MEC/SEESP, 2008. Disponível em: $<$ http://portal.mec.gov.br/seesp/arquivos/pdf/politica.pdf>. Acesso em: 03 fev. 2016.

Portaria no 1.679 de 2 de dezembro de 1999. Dispõe sobre requisitos de acessibilidade de pessoas portadoras de deficiência, para instruir os processos de autorização e de reconhecimento de cursos, e de credenciamento de instituições. Diário Oficial da União, Brasília, 03-12-1999.

Portaria no $\mathbf{3 . 2 8 4}$ de 7 de novembro de 2003. Dispõe sobre requisitos de acessibilidade de pessoas portadoras de deficiência, para instruir os processos de autorização e de reconhecimento de cursos, e de credenciamento de instituições. Diário Oficial da União, Brasília, 11-11-2003.

Relatório sobre a Política Linguística de Educação Bilíngue -Língua Brasileira de Sinais e Língua Portuguesa. Brasília, DF, MEC/SECADI, 2014. 
CAETANO, J. F.; LACERDA, C. B. F. de. Libras no currículo de cursos de licenciatura: estudando o caso de Ciências Biológicas. Coleção UAB-UFSCar, Língua Brasileira de Sinais = Libras, uma introdução; capítulo 9 São Carlos, 2011.

CAMPELLO, A. R. S. e. Aspectos da visualidade na educação de Surdos. Tese - Programa de Pós-Graduação de Educação da Universidade Federal de Santa Catarina. Florianópolis, 2008.

CAPOVILLA, F. C. Filosofias educacionais em relação ao Surdo: do oralismo à comunicação total ao bilinguismo. Instituto de Psicologia, Universidade de São Paulo, Revista Brasileira de Educação Especial, v.6, n.1, 2000.

CARMONA, J. C. C. A dicionarização de termos em língua brasileira de sinais (Libras) para o ensino de Biologia: uma atitude empreendedora. Dissertação (Mestrado) - Universidade Tecnológica Federal do Paraná, Programa de Pós-Graduação em Ensino de Ciências Humanas, Sociais e da Natureza. Londrina, 2015.

CHOI, D. [et al.]; organizadora Maria Cristina da Cunha Pereira. LIBRAS - conhecimento além dos sinais. 1. ed. - São Paulo: Pearson Prentice Hall, 2011.

COSTA, E. S. da. O ensino de Química e a Língua Brasileira de Sinais - Sistema SignWriting (LIBRAS-SW): monitoramento interventivo na produção de sinais científicos. Dissertação (Mestrado), Pós-Graduação em Ensino de Ciências Naturais e Matemática, Universidade Federal de Sergipe, 2014.

COSTA, J. P. B. A educação do Surdo ontem e hoje: posição, sujeito e identidade. Campinas (SP): Mercado das Letras 2010.

COZENDEY, S. G. A Libras no ensino de Leis de Newton em uma turma inclusiva no Ensino Médio. Tese (Doutorado) - Universidade Federal de São Carlos, UFSCar, 2013.

DAVÍDOV, V. V. Tipos de generalización en la enseñanza. Havana: Pueblo y educación, 1978.

DELL'ARINGA, A. H. B.; ADACHI, E. S.; DELL'ARINGA, A. R. A importância da leitura orofacial no processo de adaptação de AASI. Rev. Bras. Otorrinolaringol. vol.73 no.1 São Paulo Jan./Fev. 2007. Disponível em: 
$<$ http://www.scielo.br/scielo.php?script=sci_arttext\&pid=S003472992007000100 016>. Acessado em: 20/10/2016.

FAULSTICH, Enilde. A Terminologia entre as políticas de língua e as políticas linguísticas na educação linguística brasileira. 2013.

FELIPE, T. A. Introdução À Gramática de LIBRAS - Rio de Janeiro: 1997.

FELTRINI, G. M. Aplicação de modelos qualitativos à Educação Científica de surdos. Dissertação (mestrado), Universidade de Brasília- UnB, Programa de Pós-Graduação em Ensino de Ciências, 2009.

FERREIRA, A. B. O processo de escolarização de crianças surdas no Ensino Fundamental: Um olhar para o ensino de ciências articulado aos fundamentos da astronomia. Dissertação (Mestrado) - Universidade Estadual Paulista. Faculdade de Ciências, Bauru, 2015.

FERREIRA-BRITO, Lucinda. Por uma gramática de línguas de sinais. Rio de Janeiro, RJ: Tempo Brasileiro, 1995.

FERNANDES, J. M. Propostas Alternativas para a Educação Inclusiva a surdos: Enfoque nos conteúdos de balanceamento de equações Químicas e estequiometria para o Ensino Médio. Dissertação (mestrado) - Universidade Federal de Juiz de Fora, Instituto de Ciências Exatas. Programa de Pós0Graduação em Química, 2016.

FILHO, M. A. T. V. Ensino de Ciências para alunos surdos: aplicação de modelo qualitativo baseado em raciocínio qualitativo para alunos do Ensino Fundamental I. Dissertação (mestrado) - Programa de Mestrado Profissional em Projetos Educacionais de Ciências - Escola de Engenharia de Lorena da Universidade de São Paulo, 2016.

GALVÃO, M.C.B. O levantamento bibliográfico e a pesquisa científica. In: Laércio Joel Franco, Afonso Dinis Costa Passos. (Org.). Fundamentos de epidemiologia. 2ed. A. 398 ed. São Paulo: Manole, 2010, p. 377.

GESUELI, Z. M. Lingua(gem) e identidade: a surdez em questão. Educ. Soc., Campinas, vol. 27, n. 94, p. 277-292, jan./ abr. 2006. Disponível em <http://www.cedes.unicamp.br> Acesso em: 12/01/2016. 
GLAT, R. N.; LIMA, M. L. Políticas educacionais e a formação de professores para a educação inclusiva no Brasil. Comunicações, Piracicaba. Vol. 10, n.1. 134-141, 2003.

GOLDFELD, M. A criança Surda: Linguagem e Cognição numa perspectiva sóciointeracionista. São Paulo: Plexus, 2001. p. 34.

INÁCIO, W. H. Inclusão escolar do deficiente auditivo: contribuições para o debate educacional. Faculdade de Educação/ Instituto de Psicologia, 14p, 2004.

KARNOPP, Lodenir B. Fonética e fonologia. Apostila do curso de Letras-Libras- licenciatura e bacharelado. [s/d]

KOEHLER, W., Zur Psychologle des Schimpansen. Psychol. Forsch, 1921.

LABOURIT, E. O vôo da gaivota. São Paulo: Best Seller, 1994.

LABURÚ, C. E.; ARRUDA, S. M. de; NARDI, R. Pluralismo Metodológico no Ensino de Ciências. Ciência \& Educação, v. 9, n. 2, p. 247260, 2003.

LACERDA, C. B. F. de; ALBRES, N. A de; DRAGOS, S. L. S dos. Política para uma educação bilíngue e inclusiva a alunos Surdos no município de São Paulo. Educ. Pesqui., São Paulo, v. 39, n. 1, p. 65-80, jan./mar. 2013.

, C. B. F. de. O que dizem/sentem alunos participantes de uma experiência de inclusão escolar com aluno Surdo. Rev. Bras. Ed. Esp., Marília, v.13, n.2, p.257-280, 2007.

C. B. F. de. Um pouco de história das diferentes abordagens na educação dos Surdos. Disponível em: $<$ http://www.porsinal.pt/index.php?ps=artigos\&idt=artc\&cat=7\&idart=248> Acesso em 13 de setembro de 2016.

LANGHI, R. Astronomia observacional para professores de ciências: uma introdução ao conhecimento do Céu Noturno. In: LONGHINI D. M (Org.). Educação em Astronomia: Experiências e Contribuições da Prática Pedagógica, Campinas: Átomo, 2010.

LEITE, T. de A. A segmentação da língua de sinais brasileira (Libras): um estudo linguístico descritivo a partir da conversação espontânea entre Surdos. Tese (Doutorado em Estudos Linguísticos e 
Literários em Inglês) - Faculdade de Filosofia, Letras e Ciências Humanas, Universidade de São Paulo, São Paulo, 2008.

LODI, A. C. B. Educação bilíngue para Surdos e inclusão segundo a Política Nacional de Educação Especial e o Decreto no 5.626/05. Educ. Pesqui., São Paulo, v. 39, n. 1, p. 49-63, jan./mar. 2013.

LOPES, M. C. Surdez \& Educação. $2^{\underline{a}}$ edição revisada e ampliada Belo Horizonte: Autêntica Editora, 2011.

MARCONDES, N. A. V.; BRISOLA, E. M. A. Análise por triangulação de métodos: um referencial para pesquisas qualitativas. Revista Univap São José dos Campos-SP-Brasil, v. 20, n. 35, jul.2014.

MARTINS, H. H. T. de S. Metodologia qualitativa de pesquisa. Educação e Pesquisa, São Paulo, Faculdade de Educação da Universidade de São Paulo, v.30, n.2, p.289-300, maio/agosto 2004.

MARTINS, I.; GOUVÊA, G.; PICCININI, C. Aprendendo com Imagens. Cienc. Cult. vol.57 no.4 São Paulo Oct./Dec. 2005.

MENDES, G. E. A radicalização do debate sobre inclusão escolar no Brasil. Revista Brasileira de Educação, São Paulo, v.11, n.33, p.387-405, 2006.

MENEZES, M. V. M et al. Concepções de Licenciandos em Física durante a formação inicial acerca dos desdobramentos para a inclusão do aluno Surdo. In: CONGRESSO BRASILEIRO DE EDUCAÇÃO ESPECIAL, 4., 2010, São Carlos. Anais... São Carlos: CD ROM.

MORTIMER, E. F. Construtivismo, mudança conceitual e ensino de Ciências: para onde vamos? Investigações em Ensino de Ciências - Serra Negra - SP, V1(1), pp.20-39, 1996.

MORTIMER, E. F. Evolução do atomismo em sala de aula: mudança de perfis conceituais. São Paulo, Faculdade de Educação da USP. (Tese, Doutorado), 1994.

MORTIMER, E. F. Conceptual Change or Conceptual Profile Change? Science and Education, 4, 267-285, 1995.

MORTIMER, E. F. Linguagem e formação de conceitos no ensino de ciências. Belo Horizonte: Ed. UFMG, 2000.

MOURA, M. C.; LODI, A. C. B.; HANRISON, K. M. P. História e educação: o Surdo, a oralidade e o uso de sinais. In.: LOPES FILHO, O.; 
CAMPIOTTO, A. R. (Org.). Tratado de Fonoaudiologia. Ribeirão Preto: Tecmedd, 2005. P. 341-363.

MOURA, M.C. O Surdo: caminhos para uma nova identidade. Rio de Janeiro: Revinter, 2000.

OLIVEIRA, A. P. de. Sobre a ação mediada: intervenções pedagógicas no Ensino de Ciências para surdos em sala bilíngue. Dissertação (Mestrado) - Universidade Federal de Goiás, Programa de PósGraduação em Educação em Ciências e Matemática - Goiânia, 2016.

OLIVEIRA, C. L. R. de. Reflexões sobre a Formação de Professores em Química na Perspectiva da Inclusão e Sugestões de Metodologias Inclusivas aos Surdos Aplicados ao Ensino de Química. Dissertação (mestrado) - Universidade Federal de Juiz de Fora, Instituto de Ciências Exatas. Programa de Pós0Graduação em Química, 2014.

PEIXOTO, E. D.; RAMOS, E. Formação do professor de física para o ensino de astronomia: algumas possibilidades e reflexões. In: reunião anual da sociedade brasileira para o progresso da ciência- SBPC, 63, 2011, Goiânia. Anais... Goiânia: CD ROM.

PERLIN, G. T. T. Identidades Surdas. In: SKLIAR, C. (Org.). A surdez: um olhar sobre as diferenças. Porto Alegre: Mediação, 1998.

PERLIN, G. T. T. O ser e estar sendo Surdos: alteridade, diferença e identidade. Tese (doutorado) Universidade Federal do Rio Grande do Sul, Faculdade de Educação. Porto Alegre, RS - 2003.

PIZZIO, A. L.; QUADROS, R. M. Aquisição da língua de sinais. Apostila da Universidade Federal de Santa Catarina, Licenciatura em LetrasLibras na Modalidade a Distância. Florianópolis, 2011.

PROMETI, D.; COSTA, M. R.; TUXI, P. Sinal-termo, língua de sinais e glossário bilíngue: atuação da Universidade de Brasília nas pesquisas terminológicas. I Congresso Nacional de Libras da Universidade Federal de Uberlândia - I Conalibras-UFU, 2015.

QUADROS, R. M.; KARNOOP, L. B. Língua de Sinais Brasileira estudos linguísticos. Porto Alegre, Artes Médicas, 2004

REILLY, L. O papel da Igreja nos primórdios da educação dos surdos. Revista Brasileira de Educação v. 12 n. 35 maio/ago. 2007 
RESENDE, L. M. A. de R. INCLUSÃO DE DEFICIENTES AUDITIVOS NO ENSINO MÉDIO: Inserção de atividades demonstrativas no ensino de Física. Dissertação (mestrado) Fundação Universidade Federal do Mato Grosso do Sul, Centro de Ciências Exatas e Tecnologia, Campo Grande - MS, 2014.

ROCHA, S. INES Instituto Nacional de Educação de Surdos. Revista Espaço: Edição comemorativa, 140 anos. Belo Horizonte: Editora Líttera, 1997.

ROSA, P. R. S.; Instrumentação para o Ensino de Ciências. Ed. Universidade Federal de Mato Grosso do Sul, Campo Grande, 2010.

SANTOS dos, E. F.; SANTOS dos, C. F.; SANTOS dos, R. C. Sintaxe da Libras e a (re)afirmação linguística: $O$ óbvio que ainda precisa ser dito. Interdisciplinar -Edição Especial ABRALIN/SE, Itabaiana/SE, Ano VIII, v.17, jan./jun. 2013.

SAVIANI, D. Educação: do senso comum à consciência filosófica. SP Ed. Cortez, 1985.

SÁ, N. R. L. Cultura, poder e educação de Surdos. Manaus: Editora da Universidade Federal do Amazonas, 2002.

SACKS, O. Vendo vozes: uma jornada pelo mundo dos Surdos. Rio de Janeiro: Ed. Imagino, 1990.

SANTANA, A. P.; BERGAMO, A. Cultura e identidade Surdas: encruzilhada de lutas sociais e teóricas. Educ. Soc., Campinas, vol. 26, n. 91, p. 565-582, Maio/Ago. 2005. Disponível em <http://www.cedes.unicamp.br> Acesso em: 12/01/2016.

SANTANA, A. P. Surdez e linguagem: aspectos e implicações neurolinguísticas/ Ana Paula Santana - São Paulo: Plexus, 2007.

SILVA, J. F. C. O ensino de física com as mãos: Libras, bilinguismo e inclusão. Dissertação (mestrado) Universidade de São Paulo - USP. Instituto de Física, Instituto de Química, Instituto de Biociências e Faculdade de Educação, 2013.

SKLIAR, C. - La Historia de los Sordos: Una Cronología de Maios Enten $\neg$ didos y de Malas Intenciones. Trabalho apresentado no 11 I Congreso Latinoamericano de Educación Bilingüe para los Sordos. MeridaᄀVenezuela, 1996. 
SKLIAR, C. Os estudos Surdos em educação: problematizando a normalidade. In: SKLIAR, C. (Org.). A surdez: um olhar sobre as diferenças. Porto Alegre: Mediação, 1998.

SOFIATO, C. G.; REILY, L. H. Dicionarização da língua brasileira de sinais: estudo comparativo iconográfico e lexical. Educ. Pesqui., São Paulo, v. 40, n. 1, p. 109-126, jan./mar. 2014.

SOUZA, M. R. O professor intérprete de língua de sinais em sala de aula: ponto de partida para se repensar a relação ensino, sujeito e Educação. Revista Temática Digital linguagem - ETD, Campinas, v.8, n. esp., p.154-170, jun, 2007.

SOBRAL, Adail. Insularidad, extraposición, alteridad e identidad: exploraciones especulativas. La Pagina, 88 (especial: La Fascinación Insular), ano XXII, n. 6, p. 95-109, 2010.

SOLER, M-A. Didáctica multisensorial de las ciencias: Un nuevo método para alumnos ciegos, deficientes visuales, y también sin problemas de visión. Barcelona: Ediciones Paidós Ibérica, 1999.

STOKOE, W. C. Sign language struture: an outline of the visual communication system for the American deaf. Buffalo: Buffalo University, 1960.

STRNADOVÁ, V. Como é ser Surdo. Editado pela união de Surdos Tcheca, ed. Babel, Petrópolis - RJ, 2000.

TAVARES, L. H. W; CAMARGO, E. P de. Inclusão Escolar, Necessidades Educacionais Especiais e Ensino de Ciências: Alguns Apontamentos. Revista Ciência em tela - v. 3, n.2, 2010.

TOSTA, S.; MOREIRA, H.; BUENICONTRO, R. Os usos da etnografia na pesquisa educacional. Trabalho apresentado na 26르. Reunião Brasileira de Antropologia, realizada entre os dias 01 e 04 de junho, Porto Seguro, Bahia, s.d.

UNESCO. Declaração da Guatemala, 2001 (Decreto nํ. 3.956 de 2001). Convenção Interamericana para a Eliminação de Todas as Formas de Discriminação contra as Pessoas Portadoras de Deficiência. Brasília, 2001.

Declaração de Salamanca sobre princípios, Política e práticas na área das necessidades educativas especiais, 1994. 
Declaração Mundial sobre Educação para Todos:

satisfação das necessidades básicas de aprendizagem, 1990.

VIGOTSKI; LURIA, A. R.; LEONTIEV, A. N. Linguagem, desenvolvimento e aprendizagem. Tradução Maria da Penha Vilalobos. 7. ed. São Paulo: Ícone, 2001.

, L. S. Pensamento e linguagem. 3. ed. São Paulo: Martins Fontes, 1993.

La conscience comme probléme de la psychologie du comportamet. Traduction Française de F. Séve. Sociéte Francaise, n. 50, 1994

Déficience et défectologie mentale. Delachaux et Niestlé, p. 117-154, 1994.

The development of academic concepts in school aged children. In: R. VAND. V; VALSINER. J (Eds.) The Vygotsky Reader. Cambridge-Oxford: Blackwell. 1994. p. 355-70.

. Teoria e Método em Psicologia. 1. ed. São Paulo: Martins Fontes, 1926/1996.

Obras Escogidas. Fundamentos de Defectologia. Tomo V. Madrid, España, 1997.

A Formação social da mente. 0 desenvolvimento dos processos psicológicos superiores. 3. ed. São Paulo: Martins Fontes, 1998. A Construção do Pensamento e da Linguagem. 1. ed. São Paulo: Martins Fontes, 2001.

Psicologia Pedagógica. 3. ed. São Paulo: Martins Fontes, 2010. 


\section{APÊNDICES}

Apêndice 01: Autorização de pesquisa solicitada aos alunos do Colégio Neusa Bassetto.

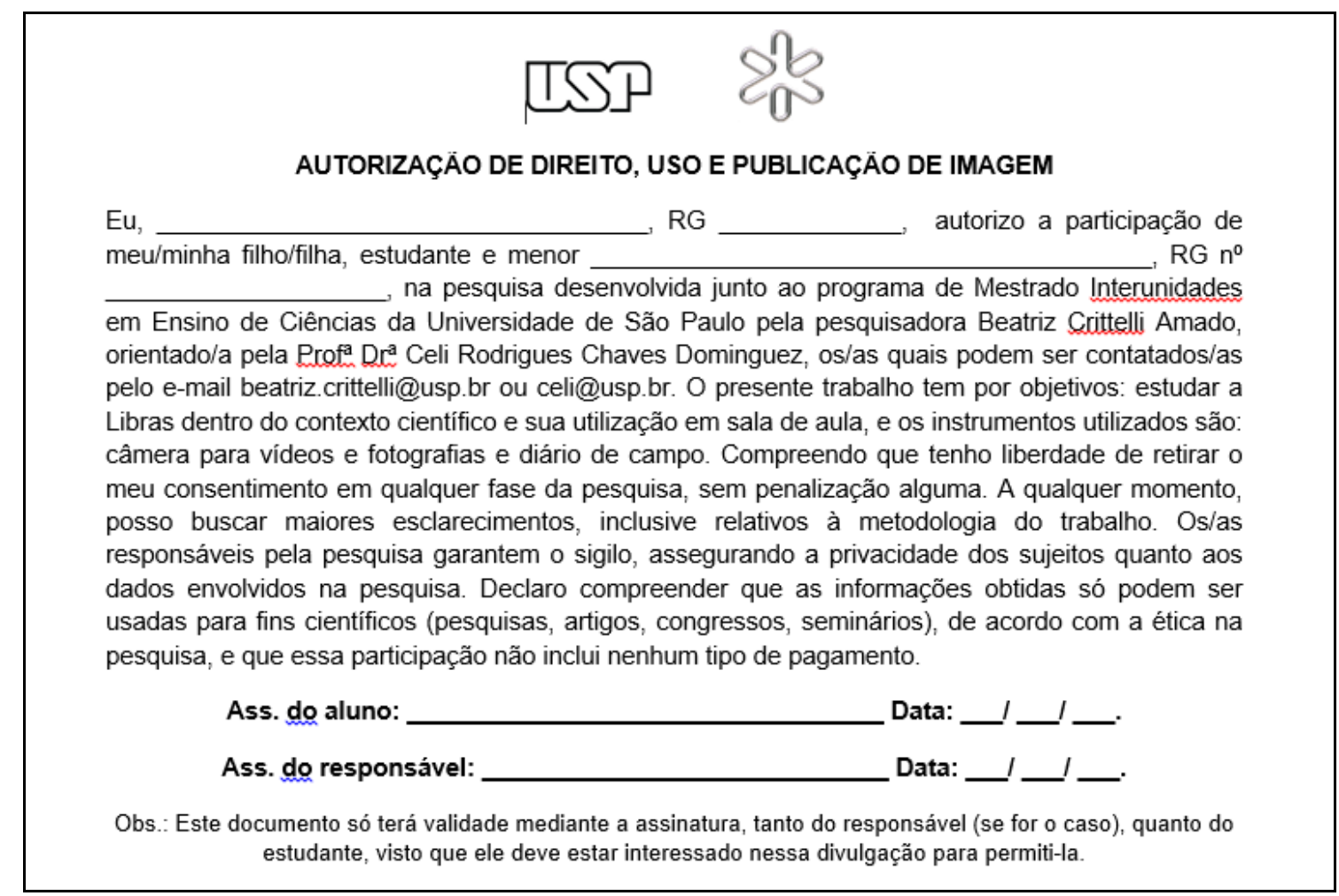

Apêndice 02: Transcrição da entrevista com o Professor de Ciências da EMEBS em que a pesquisa foi realizada.

Dias: 18 e 19 de junho de 2015

Tempo total: 68 minutos

\section{Apresentação pessoal}

Meu nome é Danilo, sou Prof da EMEBS Neusa Bassetto para Surdos em São Paulo.

\section{Trajetória até a escola, o que o motivou a trabalhar com os Surdos?}

Então, eu cheguei aqui em 2010, quando eu entrei na prefeitura eu já queria, alguns fatores são relevantes... 2 deles... 2 não só um, conforme vou falando vou enumerando (indicando os dedos). $O$ fato de ser perto de casa foi bastante relevante para ter qualidade de vida (um dedo), o fato de ser uma língua completamente diferente, se representar um desafio (dois dedos), o fato de nunca ter aparecido um professor na escola, ou seja, então quando eu 
chegasse aqui de certa forma eu teria meu espaço garantido, e... começar para mim uma coisa completamente nova, como professor já trambalhava ante de vir aqui, na prefeitura, mas tudo isso iria ser bastante considerado. De certa forma eu também sabia um pouco do tamanho das dificuldades que eu teria que passar por aqui. Mas sabia pouco, é diferente de você imaginar o que vai acontecer e de fato acontecer.

\section{Em relação ao ensino de Surdos, por que os Surdos?}

Por questão da língua, eu sabia que a língua seria uma coisa completamente nova para mim não imaginava de fato o quê, como eu falei, não sei exatamente, não sabia até aquele momento o porquê de fazer isso mas quando eu vim para cá, a questão de ensinar ciências em uma outra língua para mim parecia ser um desafio significativo, além das outras coisas que mencionei.

\section{Qual foi o seu primeiro contato com um Surdo na vida?}

Eu sempre morei no Tatuapé, e tinha um senhor que lutava box do lado da minha rua e ele não nasceu Surdo, foi ficando Surdo. Eu não sei exatamente o porquê eu também não falava, mas ele lutava box, e quando ele ficou sabendo que eu também lutava box a gente começou a conversar e ele usava muitos gestos porque ele não sabia usar a língua de sinais, o gesto dele era confuso, e aí as vezes eu sentava com ele e tentava conversar (risos). Não sei exatamente onde a gente chegava, tinha impressão de saber alguma coisa, mas não sei. Isso foi por volta de 95, 96, que isso foi a época que eu me lembro, o que tenho de mais marcante, eventualmente eu encontro ele perto de casa, andando pela feira, mais velho... bem mais velho que eu. Isso foi a primeira vez e... de'pois não me lembro de ter essa experiência novamente a não ser no curso da Pós-Graduação que tinha o filho de uma pessoa que cursava com a gente que era Surda, não me lembro de outra pessoa Surda que tivesse chegado no curso... acho que teve uma professora também...não, teve uma professora que chegou a substituir em caráter de substituição, que também não podia ensinar língua de sinais para nós, era um negócio esquisito na Pós-Graduação não ter língua de Sinais. Aí depois tive nos cursos que eu fiz numa instituição particular do Tatuapé, e por fim aqui na escola de forma mais frequente.

5. Em qual período surgiu sua motivação para trabalhar com o Ensino de Surdos, na graduação, na pós?

Na Pós-Graduação eu já vim motivado porque eu entrei na prefeitura... eu entrei na prefeitura em fevereiro, não lembro se abril, maio, ou março e abril, algo assim, e eu já estava fazendo a pós-graduação, já com a intenção de vir para cá. Quando eu entrei na prefeitura eu falei "eu vou trabalhar neste lugar", mais do que qualquer outro. Quando eu vim um estágio aqui eu falei "eu vou trabalhar aqui" e em 2010 em vim para cá e assim aconteceu. Então, na pósgraduação isso sempre foi o meu estímulo para vir para cá, mas não sei, não sei exatamente qual foi, de repente pode ter sido este senhor, né que eu tive 
contato quando era adolescente ainda. Não sei dizer mas é lógico que se tudo que aconteceu for considerado relevante, talvez, o fato de ser o primeiro, de garantir vaga aqui na escola, de ser o professor que de repente não teria que ficar disputando com outros aqui na escola para poder ter as minha aulas. Eu sempre falei, eu preciso ter o meu espaço para poder desenvolver a minha prática de ensino

6. Em relação as aulas que acompanhei, gostaria que apresentasse a turma, o tema de aula que foi estudado semestre passado e os subtemas.

Então, o tema que a gente trabalhou ano passado foi feito com $\circ 7^{\circ} \mathrm{C}$, praticamente do meio para o final do segundo semestre, no final do terceiro bimestre. A gente trabalhou um pouquinho de relações ecológicas e estava falando um pouquinho de predação não foi? Relação presa e predador em essência né? Falamos um pouco de cadeia alimentar com a intenção na verdade, de produzir alguma coisa mais próxima de teia alimentar, trabalhar um pouco os sinais para poder estabelecer uma comunicação mais clara porque a gente começou a ver nas construções que os sinais que estavam sendo usados não faziam muito bem com que eles entendessem o que estava sendo comunicado entre si, muito mais do que eu falando para eles é um falando para o outro e de repente utilizando sinais diferentes não conseguiam estabelecer uma comunicação que fizesse com que depois eles pudessem conversar sobre o assunto. Eu acho que basicamente foi isso né?

7. Dividindo um pouco na sequência dos conteúdos, a primeira parte que acompanhei foi a explicação de mimetismo, camuflagem e aposematismo, como você pensou nessa sequência com os alunos?

Eu sempre penso que com o que eles já podem fazer sozinhos né? Com o que eles já podem fazer com uma certa autonomia, porque se eu pensar que eles podem fazer com autonomia eu consigo partir do que eles já sabem fazer ir pra algum outro lugar, e, basicamente do que a gente mais ouve falar quando se está falando de aprendizagem sendo um referencial teórico se diz o Vigostki, com o nível de desenvolvimento real e você a partir do nível de desenvolvimento real você vai para a zona de desenvolvimento proximal, só que a gente está sempre usando uma coisa que eles podem fazer sozinhos para entender um pouco disso, para tentar desenhar um pouco disso, isso no intuito de conhecer o aluno e depois vou estabelecer alguns é... objetivos que vou precisar influenciar um pouco mais, não sei se influenciar é a melhor palavra, mas vou precisar intervir de uma forma um pouco mais constante, que eu já sei até aqui, é uma questão de auto-estima também, que isso eu já sei até aqui de repente eu construo, por que tem que construir isso né. Eu quando cheguei aqui, relembrando a trajetória, muitas vezes os alunos viam alguma coisa que a gente tava... os alunos não, os estudantes, muitas vezes eles vinham para cá e aí propunham alguma coisa nova, algum assunto que eles não tinham contato, algumas coisas que eles estivessem visto, ou que não conhecessem inda mesmo que tivessem visto. Aí eu começava a apresentar, 
começava a explicar, nós começávamos a discutir, levava a discussão por uma certa linha e muitas vezes eles falavam que não, ouvinte pode fazer e Surdo não pode. $E$ isso foi marcado também por causa do começo da nossa construção aqui que a gente participou de um concurso, um concurso sobre ilustração que tinha a ver sobre câncer no intestino e tal e "quem é que vai competir?" eles perguntaram, "a, vão competir os Surdos e os ouvintes", "a, então vai ser um monte de escolas de ouvintes e a nossa escola de Surdos? "é" "a, não vai dar...". Então de certa forma quando eu apresento alguma coisa nova eu tento mostrar para eles que eles já podem fazer alguma coisa. Então a ideia foi a partir da camuflagem e do mimetismo, eu apresentei algumas sequencias de imagens aleatoriamente organizadas, e então a partir dessas imagens a gente começou a construir alguns sinais, eu perguntava para eles: "isso aqui, o que está acontecendo com o animal?" apresentando uma foto relacionada com a camuflagem, "e nessa aqui?" aí apresentava uma foto relacionada ao mimetismo, e nisso estava estabelecendo alguma relação com eles com a intenção de perceber quais sinais que eles associavam com cada uma das situações e percebi que um mesmo aluno podia usar um mesmo sinal, por exemplo, para situações diferentes, então por exemplo, ele usava para camuflagem e mimetismo o mesmo sinal, então como fazer para tentar diferenciar, fazer com que ele percebesse que existe alguma diferença. Então, quando fomos fazendo isso, isso pôde ser capturado, tinha um outro elemento também que estava relacionado a coloração que era a produção, a produção não, a utilização de veneno para as relações ecológicas então, eu enquanto uma presa, posso mostrar que eu tenho veneno, em relação ao mimetismo, eu enquanto predador também mostro que eu tenho veneno mas também, de certa forma, dou uma indicação à minha presa de que ela precisa se preocupar com alguma coisa, então minha coloração é usada para esse tipo de coisa, ou... é... basicamente é isso. Então são as três situações: a camuflagem, o mimetismo e o aposematismo. A camuflagem e o mimetismo foram os dois que causaram mais confusão, como é que eu fiz isso para que a aparência disso ficasse mais... como a gente está trabalhando com imagens, estávamos utilizando slides com power point, né, então o que eu fiz, a partir das imagens que eles escolheram, né como um grupo, então tinha algumas imagens que eram referência, então algumas das coisas como por exemplo, tinha a imagem da coruja, e atrás da coruja tinha uma árvore e a coloração da coruja com a árvore se confundiam, uma imagem relacionada com a camuflagem. Só que, existia uma certa... existe uma certa semelhança também para isso, 0 mimetismo é marcado pela semelhança, a camuflagem, a função da camuflagem é, o que é feito através da camuflagem é se esconder. No mimetismo você quer parecer alguma coisa que você não é. Até falando assim né, conversando com outras pessoas sobre a estrutura, bom, mas até da forma que você explicou fica meio confuso, então a camuflagem você quer parecer, você acaba parecendo com um determinado tipo de ambiente, folhagem, uma coloração, com uma pedra, com uma rocha como quer que seja, e no outro não, você quer se assemelhar com um outro tipo de organismo. Então por exemplo, é uma flor que quer parecer um inseto, é uma borboleta monarca que é um exemplo que foi utilizado lá também né e está muito presente nas falas a 
respeito de mimetismo, tem a borboleta que quer se assemelhar a uma outra, tem um outro tipo de borboleta que eu não me lembro o nome agora... parece que tem dois olhos nas asas em forma de se assemelhar a uma coruja por exemplo e na ponta das asas tem uma semelhança com uma cobra também, então é... tentei agrupar as imagens de forma que eles percebessem né, olha quem está se escondendo eles não se parecem um animal com o outro e depois num outro agrupamento, aqui tem um animal parecido com um outro animal e para tentar eles fazerem usar os sinais que forem coincidentes, como por exemplo a camuflagem, esse animal está se escondendo neste ambiente, então se escondeu (sinalizando) aqui no mimetismo este animal não está se escondendo neste ambiente, esse animal está exposto, mas quando ele está exposto ele parece um animal mais agressivo do que ele é, um animal mais perigoso do que ele é ou um animal que oferece alguma coisa que ele está procurando, um ser vivo no caso, por exemplo, no caso de uma flor que se assemelha a um inseto, então eu queria que eles percebessem esse tipo de coisa e que usassem por exemplo um sinal para mimetismo (sinal) que usassem essa semelhança, inclusive porque quando se usa as ilustrações como exemplo a borboleta monarca, normalmente tem uma do lado da outra (sinalizando) aqui tem a outra borboleta que eu não me lembro o nome e aqui tem a borboleta monarca com uma sabor desagradável e aqui não tem, então esse sinal foi pensado por causa disso. Isso pensando nessa primeira parte e com relação a parte do aposematismo, relacionado a veneno né, então a marcação foi essa, isso para eles usarem né, mas o sinal que a gente usou agora não estou conseguindo me lembrar (eu mostrei a ele) é isso né? Então foi veneno (sinais), as cores do veneno.

8. Só para ter como registro, peço para você fazer o sinal que ficou combinado de mimetismo, camuflagem e aposematismo.

(sinal) camuflagem (sinal) mimetismo, aí aqui porque eles acabaram usando mais de um, então eles usaram muito a questão do veneno (sinal), das cores acabou saindo mais assim do que assim (sinalizando plural e singular de cores em sinais, indicando mais singular) porque o animal acabava mostrando muito mais uma cor em destaque. Lá acabaram usando muito mais esse (cor) e muito pouco esse (cores), então para veneno (sinal), para perigo (sinal), era esse tipo de marcação, mas (veneno) esse aqui que eu me lembro muito mais do que esse (perigo). E isso é importante porque é uma questão de afinidade deles por uma determinada forma de expressão aí eu preciso reconhecer isso para saber "olha, ele está aprendendo, não está aprendendo" esse tipo de sinalização que ele está representando aqui, ela demonstra algum tipo de aprendizagem? Esse tipo de relação que eu estou construindo me ajuda a perceber essa aprendizagem, não ajuda? Então, é importante ter essas percepções e tem também por exemplo, a gente combinou (sinal de camuflagem, mimetismo e aposematismo com suas variações) mas esses dois aqui tiveram mais confusão, eventualmente eles utilizavam para camuflagem (sinal de mimetismo), voltavam para o mimetismo e também usava este (sinal de mimetismo) ou seja, o conceito aparentemente, não quer dizer que ele não tenha sido aprendido, mas pela forma como ele se expressava é possível... 
esse sinal ele... pode ser que o sinal mesmo seja inadequado para as duas situações porque não houve necessariamente essa marcação de isso aqui serve para mostrar semelhança com o lugar e talvez eles não tenham isso também aí você vai demonstrar a semelhança entre um organismo e outro e esse entre um ambiente e outro não é, ou pensar realmente de fato na função, marcar mais a função (sinalizando camuflagem) aqui ele está se escondendo já aqui ele não está escondido necessariamente, então... apesar de que isso também pode acontecer, e no final, pensando nos slides, tinha sido... é... na última construção dos slides, até para que eu pudesse enxergar isso de forma mais clara, porque na vida a gente sabe, tanto na vida quanto na natureza, não necessariamente a camuflagem ou o mimetismo, eles acontecem de forma independente, então, por exemplo, você tem um inseto que se parece com uma folha, é um organismo que se parece com um outro, mas o fato dele parecer com uma folha, ter uma coloração esverdeada e de ter sobrevivido nesse tipo de ambiente, faz com que ele esteja camuflado. Então no último slide o que que eu fiz, diferente das imagens que eu mostrei anteriormente em que o organismo se assemelhava de fato com o ambiente, eu tentei colocar umas outras situações, e que não fosse repetidas, em que esse tipo de percepção pudesse ser expressada. Então eu coloco lá um inseto que se parece com uma folha, ou com um determinado tipo de colocação, mas que ele também se parece com outro organismo, aí o estudante ele olha para aquilo lá e ele "poxa, o que que é isso?" e nos vídeos foi possível que ele vê isso, que ele olha, aí ele coloca um sinal (sinaliza camuflagem), aí ele para, pensa e coloca outro junto (sinaliza mimetismo). No aposematismo isso não aconteceu, no aposematismo isso é uma coloração de destaque então esse trabalho com a visualidade para eles ficou bastante destacado e dava para perceber isso com clareza, nessa situação as funções foram percebidas com mais facilidade do que com os outros dois, que as semelhanças marcam mais do que as diferenças.

9. Em relação ao sinal especificamente, você chegou a consultar em algum dicionário se existia essas três palavras mimetismo, camuflagem e aposematismo ou você usou outra metodologia?

A metodologia foi como eu falei antes, não adianta eu chegar com um sinal completamente novo, a não ser que esse sinal tenha um relacionamento mais fácil com o que os estudantes já saibam. Tenho o conhecimento de dicionários estrangeiros onde eu pudesse encontrar esse tipo de sinal, mas eu não usei isso. Nessa situação eu não usei. Então, a forma de construir esse sinal, essa conceituação com eles, de construir essa percepção, foi de fato fazer a leitura do que... de como de fato eles enxergavam aquela situação, e da forma com os sinais que eles já tinham se relacionavam com aquele novo aprendizado, com aquela nova estrutura de apresentação, com aquele novo conceito. Então de certa forma, a construção do novo sinal é feita com eles, inclusive porque mesmo que um sinal, hoje, por exemplo, ele não é divulgado ou não está de fácil acesso para todo mundo. Então digamos que eu trabalhe esse sinal e ele vai servir para que ele se comunique com alguém, alguém que a gente não saiba quem é e alguém que não é do meio deles provavelmente. Até colocando assim alguém que não é do meio deles, mas entre eles, essa funcionalidade, 
essa utilidade, essa comunicação, como vai acontecer? O que é mais fácil fazer, eu colocar alguma coisa nova ou usar o que eles já tem e atribuir... ajudar... a contribuir para a atribuição de um novo significado complementar ou suplementar. Eu entendo que até o momento, em muitas situações, principalmente nessa fica muito mais fácil usar o que eles já tem para poder pensar em uma nova situação. Na situação seguinte a gente teve que construir um novo sinal e aí nós tivemos que usar um outro referencial.

10.Em relação ao processo de construção do sinal, você faz com os seus alunos com o que eles têm de carga teórica, como você lidou com isso com as quatro salas do sétimo ano, surgiram sinais diferentes para os conceitos?

Então, isso foi bem marcante, para o sinal de camuflagem todo mundo (sinal de esconder) isso é extremamente relevante né, bom você ter lembrado disso. Então por exemplo, são quatro salas, $7^{\circ}$ A, B, C, e D esse sinal para camuflagem (sinalizando esconder) ele aparecia muito recorrentemente, então é um indício que na hora de se comunicar, eles poderiam usar aquilo lá para falar a respeito disso. Então poxa, por que não usar? E inclusive poderia ser um indicio para um outro professor, em uma outra situação para construir em cima do mesmo sinal, porque de certa forma a gente está construindo um conceito, um conceito pode ser explicado de formas diferentes em situações diferentes, de acordo com referenciais diferentes de acordo com o tipo de explicações. Então é... como as imagens apresentadas tanto numa sala quanto na outra foram as mesmas, elas foram apresentadas de forma aleatórias e os sinais apareciam muito recorrentemente né, do mesmo jeito em salas diferentes, falei "ah, vamos aproveitar" significa que esses alunos depois, que esses estudantes assim que saírem de uma sala e forem para outra e se for 0 caso de conversar um com o outro sobre o assunto essa comunicação provavelmente vai acontecer com mais facilidade. Para o mimetismo eu não posso afirmar muito bem, primeiro porque eu não estou lembrando exatamente.... e... (perguntei, o sinal?) o mimetismo esse aqui (sinal de parecer) mas eu não me lembro exatamente se esse sinal ele surgiu de forma tão espontânea nas salas como surgiu o de camuflagem. O de aposematismo com certeza não surgiu. Né, então o de aposematismo a gente teve que ir combinando, a gente foi marcando o que significa, coloca uma cobra lá aí fala "o que vocês pensam a respeito da cobra? Quando vocês veem uma cobra o que vocês sentem, por que que vocês sentem isso? Está relacionado com o quê, né?" Aí eles vão colocando essas coisas para fora, e aí algumas coisas que fazem vocês sentirem isso, aí vocês vão perguntando esses tipos de coisa e de repente vão surgindo elementos para vocês irem falando, são referenciais que são importantes para eles pensar os significados que essas cores têm nesse organismo, através desse questionamento, desse diálogo frequente que eles têm em sala de aula.

11. Nas quatro salas surgiram sinais muito diferentes desses que você apresentou aqui? 
Para o mimetismo.... para a camuflagem isso foi bem marcante (sinal de esconder) esconder foi muito, muito muito marcante... esconder, esconder... para o mimetismo... eu acho que... eu acho que é... eu acabei meio que induzindo eles, justamente por causa das ilustrações mais recorrentes em comparação as duas borboletas (sinal de parecer) e é só olhar a ilustração que fica muito fácil pensar a respeito disso, mas para todas as outras situações, você não tem por exemplo... é... com facilidade para encontrar a foto da coruja, da borboleta juntas assim, para se chegar a essa construção, mas quando você bate o olho, você pensa na coruja, e se você prestar um pouco mais de atenção, você enxerga a cobra na asa da borboleta. Com a lagarta, por exemplo, uma lagarta que se parece com uma cobra, também, aí a ideia foi diferente, a ideia foi mostrar primeiramente numa escala menor, ou seja, mostrava só uma fração do corpo e eles olhavam e perguntava, "Que animal é esse?" aí falavam assim "ah, esse aqui é uma cobra", "Mas tem certeza de que é uma cobra?", "Tenho, tenho certeza" aí mostrava a outra (sinalizou um aluno fazendo sinal de dúvida "pequenininho?") ou então uma cobra, que por exemplo, inflava em determinada parte do corpo, uma lagarta né, que inflava uma determinada parte do corpo e adquiria uma semelhança muito grande com uma cobra né? "Que que é isso aqui?", "ah, isso é uma cobra!", "Tem certeza?" aí mostrava de novo uma imagem em uma escala um pouco maior, e aí começava a provocar esse tipo de coisa a partir do conflito e criar algum tipo de situação... de, de.... criar algum tipo de associação. Então na construção desse sinal (sinaliza parecer) eles usam isso daqui para "parecido". Ah, mas tem outro sinal que existe para parecido? Esse aqui (sinaliza a variação que pode indicar "eu acho") mas esse daqui é utilizado para "acho", "acho"... de alguma coisa que você está pensando mas que ainda não têm muita certeza, agora esse daqui é de semelhança de fato (sinalizando parecer). Então de certa forma, foi uma construção que eu propus. No outro... como eles começaram a falar muito a respeito de veneno e associação posterior com a coloração, fui eu que contribui com esse efeito talvez por isso que ela n]ao tenha... surgido de forma tão marcante que nem eu tenha me lembrado de forma tão marcante aqui... foi o que marcou veneno (sinalizando veneno) o que marca para eles quando pensam nesse tipo de organismo é o veneno, a coloração vai servir como.... como um aviso né (sinaliza aviso) "ó percebe? É perigoso!" (sinalizando perigo) mas o que marca é o veneno quando olho para o organismo. Inclusive quando olho, por exemplo, eles olharam para um sapo, né, um sapo com uma coloração bonita, vistosa, um sapo muito azulado, um sapo muito preto, um sapo muito vermelho, aí eles olhavam para o animal e falavam assim: "(pergunta sinalizada)" aí eu falava "hum... não". Mas a questão é... eles falavam que o veneno estava relacionado com é... com um determinado tipo de animal. Eles usavam o veneno, falavam do veneno, mas eles não falavam assim "nossa, a cor! Por que a cor?" (sinalizando a pergunta) Não perguntavam da cor, eles perguntavam muito mais do perigo do que do veneno. Então isso pode ter acontecido por causa dessa situação. Agora... se vale a pena a gente... ou eu pensar...não, vamos pensar realmente se precisa corrigir se a coloração (sinaliza cor) perigosa (sinaliza perigo) né, ou um aviso de perigo (sinaliza) e eu permiti na verdade com que isso também 
acontecesse, eu tenho que usar isso que eles estão falando. Se eu falar "não, não pode, não é isso" entendeu. A intenção da variação, de qualquer variação é você conseguir entender o que ele está pensando, o que o outro está pensando para promover uma nova intervenção, não é para falar "você está certo ou você está errado". Então se eu fizesse dessa outra forma, olha, tem que usar esse sinal eu não conseguiria enxergar o que cada um deles estão atribuindo de significado para cada um dos sinais ou as construções que eles anda fazendo ok?

12. Em relação aos outros sinais que surgiram ao longo das aulas que foram: presa e predador, teia e cadeia alimentar como parte da sequência. Vi que também surgiram sinais, você chegou a consultar se existem esses sinais, como foi esta construção?

Sim, de presa e predador a referencia não tinha anteriormente, mas o sinal de cadeia alimentar, tem um no livro "de sinal em sinal" (sinaliza o que estava fazendo - cadeia) se eu bem me lembre... o que a gente usou na sala de aula foi esse, então de cadeia alimentar. Para presa e predador a gente não tinha encontrado, eu comecei fazendo uma indicação para poder tentar mostrar a classificação porque o que aconteceu, quando a gente começou a fazer a construção na sala de aula os estudantes começaram a fazer o que... eles começavam... eu perguntava "presa, o que acontece? (sinaliza atacar na mão)" "predador, como é que acontece? (sinaliza atacar na mão)" aí eles "ah...." aí perceberam que existia alguma confusão neste sentido, então precisava ter algum tipo de classificação e aí relacionada a ação de um determinado sujeito, e o sinal de fazer por exemplo (sinaliza o sinal) é esse aqui ó, é o sinal de eu faço, essa mão é minha. [indiquei que eu conhecia um outro e sinalizei com o polegar] esse aqui é o mais comum, essa mão é minha, na verdade esse aqui é o que tem mais a ver com a ação, esse aqui (indicando o meu) tem mais a ver com o português, não sei exatamente o porquê, né.. mais esse aqui é o de fazer, de você pegar lá e "vai, faz" né... então por exemplo, se eu coloco lá fazer nesse sentido e marco esse aqui (indicando a mão esquerda) e faço assim é esse que foi comido (ME parada e mão direita ataca) se eu marcar esse aqui e fizer assim (marcando ME e atacando a MD) é desse que eu tenho que me lembrar. Aí a gente começou a trabalhar com esse sinal na sala mais ainda sim ficava uma coisa meio estranha, até que numa sala, uma das salas os estudantes, meio espontaneamente o Vitor, ele deixou surgir, ou... não é que ele deixou surgir né, ele refletindo aparentemente da construção que a gente estava fazendo ele fez assim (sinaliza o sinal de presa e predador) aí a gente teve uma outra situação de construção. Essa aqui permaneceu (sinaliza o sinal de cadeia alimentar) mas depois consultando um dicionário de fora e relacionado com outra experiência que eu tive quanto formador, a gente discutia bastante essa questão da estruturação de sinais principalmente quando se falava de cadeia alimentar, porque é um exemplo que eu já passei para você, já passei em palestra lá e que é a história do "gato comeu o rato" e foi uma história que um outro professor passou para mim que é o Professor Celso que estava na minha formação e que achei que o exemplo que ele deu foi tão bom que acabei levando ele para várias outras situações e um dia esse 
exemplo... tanto é que esse exemplo foi tão significativo né que quando chegou na parte de cadeia alimentar ele me ajudou a refletir a respeito da construção de cadeia alimentar porque quando você começa com a construção de cadeia alimentar, pensando em três organismos: vamos pensar num vegetal, pensar num inseto, qualquer um, e pensar numa ave (sinaliza cada um) aí se eu começar a construção neste sentido, se eu começo a construção fazendo assim (sinaliza o sinal de pássaro) na verdade vamos voltar no gato e rato porque a referência vai ajudar a entender, é assim, em português você tem o gato comeu o rato (sinaliza o sinal dos trÊs) mas o rato continua lá (indicando a mão em sinal de rato), em língua de sinais você tem o rato, o gato comeu (indica com uma mão o sinal de rato ME, MD sinaliza gato e MD ataca ME)[inferência minha: o comer passa não a ser mais na boca e sim no objeto] sim, o objeto que vai ser comido. Então quando você vai pensar isso em língua de sinais, normalmente você fala assim né, pensando na questão da cadeia alimentar e nos três, o passarinho comeu o inseto e o inseto come a grama, dificilmente a gente fala "o inseto come a grama e o passarinho comeu 0 inseto" mas a produção da língua de sinais ela tem mais sentido se você fizer ela nesta direção, daqui para cá (grama - pássaro) do que dalí para cá (pássaro - grama) porque a partir do momento que você comeu o produtor, o produtor desaparece, então você aqui tem uma sequência de fatos, não pode fazr isso daqui (pássaro - grama) porque se esse daqui some (indicando 0 inseto) como é que ele vai continuar a ação? Então, pensando nessa estrutura, você tem a grama, você tem o inseto e o inseto comeu (sinaliza os sinais) passarinho e $o$ inseto aqui (sinaliza os sinais) e o inseto foi comido. Na outra estruturação você não conseguiria fazer isso aqui porque o passarinha vai comer o inseto, e como o inseto vai comer a grama se ele já foi comido? Não seria possível fazer isso. Nessa construção (sinaliza o sinal de cadeia alimentar) esse tipo de construção não fica muito visível então isso precisa ser mais bem organizado. Talves isso tenha gerado uma problema na construção que eles mesmos fizeram né e aí fui fazer a consulta em outro dicionário que vai além desse dicionário que eu falei "de sinal em sinal" britânico, dicionário britânico da língua de sinais ou escocês, eu não lembro exatamente. Lá como eles fazem o sinal de presa e predador, diferentemente de como fez o Vitor, mas não quer dizer que o que o Vitor construiu seja menos eficiente, tanto foi eficiente que na mesma situação que surgiu com a camuflagem, foi tão bem aceito com a questçao da camuflagem como esse de predador como o comer e morrer. Mas lá eles construíram de que forma (dedo indicador para frente e ME ataca o dedo) eu como (dedo indicador rente ao corpo e ME ataca) eu sou comido e aí, com a questão da cadeia alimentar com aquele outro dicionário (faz o sinal com a mão da direita $p$ esqueda abrindo e fechando) alguém que prestar um pouco mais de atenção pode construir dessa forma, mas lá já pensaram nessa situação né, então como surgiu, não surge essa ação nessa sequência, ela surge aqui, até que chegue no consumidor final (fazendo o sinal apresentado de cadeia alimentar da esquerda $p$ direita) né, desde a herbivoria até os carnívoros. Aí eu tentei passar isso para a sala, mas acho que acabei levando isso depois que você já tinha ido embora, não lembro exatamente em que momento essa pesquisa foi feita para poder levar para eles, inclusive 
porque como eu estava avaliando a construção a partir desse sinal na sala de aula (sinaliza cadeia alimentar) não... acho que surgiu não surgiu essa construção de cadeia alimentar assim? (sinaliza cadeia alimentar da outra forma) bom, mas o que tinha de ficar marcante de fato, o que foi trabalhado com eles foi essa sequência né que deve partir do produtor até o consumidor final e evitar de fazer essa sequência que você começa a fazer com o consumidor final até chegar no produtor que é muito mais comum na língua portuguesa né mas que não quer dizer que seja a regra. Então dessa forma que as coisas foram trabalhadas e tudo começou nessa sequência didática para a gente tentar entender essas diferenças entre um organismo e o outro, vamos colocar alguns organismos diferentes, organismos que não tinham surgido anteriormente para falar a respeito, os organismos que foram trabalhados durante o mimetismo, camuflagem e aposematismo, que eu pedi para eles, vamos desenhar! Agora vamos desenhar e colocar aqui... ah, você estava no dia eu acho, um dia que a gente colocou no jardim, a gente colocou lá no jardim para que eles se escondessem. Bom, vamos aplicar esse nosso conhecimento né, vamos pegar esse organismo que vai se camuflar, onde vocês colocariam por exemplo esse organismo verde, vai ficar na terra ou vamos colocar próximo das folhagens né, onde vamos colocar cada um deles. O princípio foi que todos eles esconderam todos os animais, porque a proposta era que eles se dividissem em dois grupos, o primeiro grupo ia e colocava os organismos, os organismos que cada um tinha desenhado, cada um tinha que desenhar aproximadamente três mas o número foi bem inferior a isso, chegaram a dois... não, tiveram alguns alunos que chegaram a desenhar três, então eles pegavam e, cada um deles tinha que estar relacionado a um conceito diferente, pelo menos a dois conceitos diferentes, então um desenho sobre camuflagem, os outros dois tinham que ser sobre, tinham que ser diferentes. Desenhou, leva para o jardim e coloca lá. Depois o próximo grupo vai chegar lá e tentar encontrar, se for fácil de encontrar provavelmente esse organismo servirá de alimento para outro, então foi uma referência também para a gente pensar essa diferença e relação entre presa e predador. Então pegamos estes animais que ele tinham desenhado e colamos num cartaz. Quando a gente colou no cartaz comecei a perguntar, desses animais, quem se alimenta de quem. Aí eles começaram a levantar esses apontamentos, a coruja come o sapo, a cobra come o sapo. Daí começaram a perceber que mais de um daqueles organismos podiam comer o mesmo, né e essa era uma referência importante para a gente poder pensar respeito da extinção que era uma parte do processo que eu já tinha desenhado mas... (dialogando comigo se eu consegui pegar o vídeo do Fábio) a do Fábio na rimeira, se a gente tivesse conseguido ficar com a segunda, na segunda fica muito clara essa percepção do que acontece quando desaparece um determinado organismo da cadeia alimentar, na primeira não me lembro se isso ficou claro, embora isso tenha sido uma proposta que fiz com todas as outras. Então essa construção a partir dessa relação de camuflagem e mimetismo, encontrar o animal ou não e aí passar para a parte de cadeia alimentar e essa relação entre os organismos mas isso não foi indicado, eu não cheguei para os estudantes e falei "olha, vocês devem fazer dessa forma", como vocês enxergam essas relações entre 
os organismos, eles mesmos começaram a construir tudo isso como etapa, para chegar a esses sinais que a gente foi trabalhando na segunda etapa da avaliação e tudo mais. Alguma coisa que você queria que eu tivesse falado e não falou?

13. Em sinais, possui alguma diferença entre cadeia e teia alimentar?

Essa diferença em sinais não apareceu, a gente não construiu isso dessa forma e na verdade eu nem lembro se lá nos dicionários, se surgiu um sinal diferente para os dois e não só, um sinal que eu falasse ó, vou levar isso para lá e eu consigo entender com clareza a ideia que eles estão conseguindo passar, porque se eu não entender com clareza o que eles estão querendo passar é um conceito que eu mesmo não me apropriei, então não dá para levar isso muito adiante.

14. Em relação aos próximos anos, que você for trabalhar novamente com os sétimos anos, mesmo conteúdo. Você vai utilizar os sinais que foram combinados com esses sétimos ou você vai propor com os alunos uma nova construção de sinais sobre esses conceitos?

Eles têm que ser apresentados, mas eu também não posso desvalorizar o que está construído a partir da referência deles.

15. Se surgir um sinal diferente, o que vai fazer?

Ele vai ser somado ao repertório, ele tem que ser somado ao repertório, porque na verdade é uma construção conceitual né, não é uma coisa de eu falar para os estudantes assim, a partir de agora vocês tem que pensar de determinada forma nesse sentido de falar, vocês estçao fazendo determinada construção né a partir da referência que vocês jpa tem mas essa construção não presta, joga isso fora, não, não é isso, é uma soma, porque fica mais fácil de eu somar e de repente eles sentirem esses conflitos dentro de si e eles... porque não sou eu que seleciono o que acontece dentro da cabeça deles. Quem faz essa seleção são eles, eu crio condições, se eu crio muito confronto eu crio também barreiras e as barreiras podem fechar a comunicação, eu não posso desvalorizar o que eles já tem porque é a partir disso que eles constroem.

16. Você sentiu que os alunos conseguiram utilizar os sinais em contextos diferentes? Por exemplo, o sinal de camuflagem, os alunos combinaram o sinal de esconder. Em um momento de aula eu percebi que você falou: "peguem seus desenhos e escondam eles no parque". Então você usou a mesma palavra (sinal) em um contexto em sala de aula e em outro contexto isso como uma ação de esconder. Você sentiu que os alunos conseguiam utilizar esses sinais em contextos diferentes em um momento num contexto científico e em outro no usual?

Então, as confusões elas existiram, posso falar para você mais claramente que a questão do esconder é a base para a camuflagem então essa confusão que vocês estava falando ela pode ficar um pouco mais clara na construção em língua portuguesa porque isso daqui vai continuar sendo esconder tanto em 
língua de sinais quanto em língua portuguesa (sinaliza camuflagem) aliás, tanto em língua de sinais ele pode significar tanto esconder quanto camuflagem e quando eles usarem isso daqui enquanto camuflagem eles podem estar pensando enquanto esconder também, ou seja a referência continua sendo esconder. Aí como que eu faço para enxergar se eles estão pensando nisso enquanto camuflagem, na escrita (sinaliza escrever) ou se eles estiverem fazendo alguma digitação (sinaliza digitação) na avaliação da forma como ela foi construída, para eu enxergar esse tipo de coisa eu tentei mostrar isso, como você falou, vou tentar buscar o significado, então na hora que eu coloquei lá na lousa, eu coloco por exemplo presa aí eles vão fazer a representação do sinal de presa, vou fazer o sinal de predador aí eles váo fazer a representação que era para você poder enxergar esse tipo de coisa, e tinha que ser feito o que, para que não tivesse dúvida sobre o que estava sendo perguntado eu tinha que aparecer lá para que não tivesse outras informações, "o professor deu alguma dica?", "o professor falou alguma outra coisa?", n'então isso precisava ficar claro tanto para o estudante quanto para você que estava fazendo a pesquisa, então na camuflagem e mimetismo aparece isso a gente não consegue enxergar isso e você acho que não teve a oportunidade de pegar o material escrito, talvez você tenha olhado mas aí o que aconteceu, quando chegava na parte escrita a maior parte das vezes que eles falavam camuflagem eles usavam a palavra esconder, entendeu? Tentando não quantificar, vamos qualificar isso, a palavra esconder surgiu, e para além disso né, por exemplo, o Robson na apresentação dele ficou bem marcante, quando ele estava fazendo aquela parte de camuflagem e a gente chegou a comentar a respeito disso ontem, ele olha para a coruja, olha para a árvore e faz assim (sinaliza parecer) porque ele ainda está pensando no parecer. E de fato existe essa semelhança, uma semelhança de cor. No Vigotsky ele afirma a respeito de complexo associativo por semelhança, que é uma etapa para a construção do conceito. Então poxa, está certo, a construção e o raciocínio dele está se aproximando da construção do conceito? Está se aproximando, o que é importante para a gente quanto professor? Conseguir identificar em que etapa que ele está, e daí que as próximas etapas que de fato acabamos ficando bastante limitados neste sentido é que são relacionadas ao tempo que a gente tem para fornecer outras situações ou para que eles possam experimentar outras situações em que esses complexos associativos venham a se tornar e não só... venham a se... progredir... progredir não é a melhor palavra mas que eles possam ter novos significados até chegar a um pseudo conceito e de repente, se ele já conseguir abstrair completamente, o que é muito difícil nesta etapa que a gente percebe isso nos estudantes e inclusive o próprio Vigotsky fala a respeito disso, nessa faixa etária, fica muito difícil explicar um conceito de uma forma puramente abstrata. Costuma-se recorrer bastante aos aspectos concretos, aos exemplos. Entaõ muitas vezes a gente vai chegar para eles e vai falar a respeito de camuflagem e essa é uma forma também de se fazer uma avaliação do conceito né, de como eles estão pensando a respeito dos sinais (sinaliza camuflagem e mimetismo). Então, eu chego para o estudante, dou um exemplo que ele fala (sinaliza camuflagem) camuflagem, dou um outro exemplo relacionado ao mimetismo e ele faz lá (sinaliza mimetismo) na questão da 
semelhança. Então quer dizer, existe uma diferenciação, que ele consegue fazer isso, mas eventualmente por que ele já tem isso na cabeça ele faz alguma confusão né. Então, como eu falei, quanto tempo mais a gente precisaria ter um diálogo e propor intervenções no sentido de ter exemplos o suficiente para não provocar esse tipo de confusão e de repente conseguir explicar esse conceito de forma abstrata em Língua de Sinais, ou seja, sem recorrer a exemplos, eu não sei quanto de tempo a gente precisaria, tem aí uma questão de educação especial mas para uma educação mais específica, para cada um deles.

17.Em um momento de aula percebi que houve "confusão" com o sinal esconder para camuflagem e esconder como se esconde um material. Eu lembro que você comentou :"Na ciência ESCONDER datilologia C-AM-U-F-L-A-G-E-M, fora ESCONDER na ação", então você contextualizou. Na língua portuguesa isso existe, ua mesma palavra utilizada em contextos diferentes assume significados diferentes, isso na Libras pode acontecer também. Gostaria que você comentasse sobre isso e se surgiu com outra palavra (pergunta bem sinalizada).

Faz parte da minha maturação do processo também né, é uma coisa que eu também estou aprendendo como fazer. Então eu tento fazer isso om bastante frequência, percebo que em algumas vezes isso é de fato necessário, mas eu tenho como proposta para essa etapa de ensino deles, muito mais organizar para... contribuir para organizar o que eles têm na cabeça propor situações de relacionar o que eles já têm do que propor coisas novas, embora isso seja inevitável né, porque a gente está entrando com uma linguagem diferente, o que é próprio das ciências, então existe sim o trabalho de tentar fazer, agora o exemplo assim em que essa situação aconteceu, camuflagem e mimetismo foi uma situação que isso apareceu né, em tentar delimitar uma coisa com a outra, falar olha, nesse espaço a gemte vai tentar escrever e na melhor situação tentar marcar isso para quando chegar no registro escrito né, quando for escrever isso aqui (sinaliza camuflagem) nessa situação que eu estou pedindo para vocês, qual é a palavra que vão usar C-A-M-U-F-L-A-G-E-M e aqui usar o E-S-C-O-N-D-E-R, tudo bem? Ah sim (sinaliza entendi) e na hora de escrever as coisas aconteceram de forma diferente. Na hora de presa e predador isso foi mais simples, mas por exemplo, para poder falar a respeito de presa e predador, tinha o comer e tinha o atacar, tiveram estudantes que escreveram atacar, teve outros estudantes que escreveram pegar, e outros que escreveram comer, na situação foi por exemplo, tinha o nome do animal de um lado e o nome do outro animal do outro. Era de certa forma frases lacunadas, essa lacuna entre elas tinha que ser preenchida com um verbo e esse exercício foi até vergonhoso assim para mim porque foi bastante repetitivo né e a ideia é que a partir da repetição eles pudessem se apropriar do negócio, e é engraçado também porque eu imaginei que eles fossem fazer isso com uma certa facilidade, mas teve algum tipo de conflito, teve outras situações em outros anos que isso também aconteceu né, quando você propõe um determinado sinal e espera que eles relacionem com determinada palavra e isso acontece com o nono ano quando a gente fala em energia potencial e 
energia cinética, inclusive com a experiência que eu trabalho, energia potencial (sinaliza guardar) energia que foi guardada e energia cinética (sinaliza livre) é a energia que foi liberada né, uma energia que está em movimento. No dicionário que eu falei, dicionário de língua de sinais britânico eles são o referencial de uma superfície qualquer que seja e marcam um objeto (sinaliza) ou seja, esse ponto está diretamente relacionado com energia potencial gravitacional, não era a ideia que eu queria passar porque assim ficava muito aquilo que a gente estava discutindo, porque a gente estava falando inclusive em energia potencial química, energia potencial elástica, tem diversos tipos de energia, energia potencial elétrica, todo tipo de energia potencial, e toda a energia pode ser cinética, no contexto da transformação e só que, nos primeiros exemplos que a gente trouxe isso ficou muito claro, o que é energia potencial e o que é energia cinética e num determinado momento a gente foi falar de carga de bateria do carro e aí energia cinética está relacionada com movimento aí você vai pegar por exemplo e estudar que aqui um carro está parado, bateria descarregada, foi um exemplo que os próprios alunos trouxeram, falei a ente já trabalhou os conceitos, a gente vai fazer as fotos, a gente vai fazer os vídeos a gente tinha trabalhado um pouco dos sinais, aí o exemplo que eles resolveram trazer, dois carros, um com a bateria descarregada e outro com a bateria carregada e aí tinha que colocar energia potencial e energia cinética. Aqui tinha energia química que de certa forma já tinha sido utilizada, liberada. E aqui tinha energia potencial química da bateria que iria ser transferida a partir da energia potencial elétrica, só que a energia química aqui foi praticamente ignorada e o que foi considerado foi a energia potencial elétrica, só que a energia potencial elétrica ela estava em movimento, então gerou mais um conflito, aí na hora de escrever sobre o que você vai escrever, está guardando ou está liberando, está em movimento está liberando, aí eles mesmos tiveram esse tipo de confusão, na hora de escrever isso no comecinho de 2013 aconteceu, depois em 2014 como a sequência era diferente, as propostas eram diferentes a parte escrita foi um pouco mais restrita mais em 2013 isso ficou bastante claro nas avaliações que na hora de escrever energia potencial eles escreveram guardar... em vez de escrever energia potencial escreveram guardar. Então são nestes momentos que esse tipo de discussão existe, mas ao mesmo tempo, não é uma coisa que eu vá fazer um dia, vá falar assim "ó gente, hoje vocês vão escrever... vocês vão começar a escrever de acordo com o que é de ciências então vocês não vão escrever guardar, não vão escrever esconder, vocês vão escrever potencial e vão escrever camuflagem, essa etapa do processo talvez seja ainda muito mais difícil de ser superada do que as construções em língua de sinais, porque está sendo trabalhado na segunda língua, e como na segunda língua o uso é bem recorrente e consequentemente as situações em que este uso vai sendo posto a prova são mais restritas então se atribuindo aos significados e se apropriar deles, coloca-los em novos complexos, trasformá-los em pseudo conceitos é um processo ainda mais longo, e que dentro da sala de aula ainda três aulas por semana por exemplo, fica muito difícil de ser trabalhado e aí é a ideia por exemplo de trabalhar com projeto, que é uma coisa que a gente tem tentado fazer aqui, numa esfera bem pequenininha. Respondi sua pergunta? 
18. Você é um professor ouvinte e eles estudantes Surdos. Quando você pensa nas suas aulas gostaria que você comentasse um pouco das estratégias que utiliza para quebrar essa barreira.

O que é pensado né? Eu gosto de pensar bastante na... como eu estava falando antes, é... muita coisa foi surgindo assim, de acordo com a sensibilidade mesmo, a questão de empatia, mas conforme o tempo vai passando você vai sentindo a necessidade cada vez mais como eu tenho estudado um pouco mais de Vigotsky agora, já li a respeito um pouquinho de Sócrates, Sócrates fala um pouco da ideia da maiêutica, da ideia da parteira de parir ideias através do diálogo e o Vigotsky fala do diálogo enquanto uma ferramenta de intervenção né, de mediação porque a partir de como a fala, e o que você exprime através da sua fala é o que você... é de certa forma uma parcela do que você está pensando, uma forma de colocar seu pensamento para fora, uma forma do outro saber como você está pensando e tudo isso é muito mais recente, é muito mais.. eu sempre pensei muito a respeito do diálogo e de certe forma isso tem muito de prática, de prática de ensino do que a gente vivenciou, que talvez você tenha vivenciado, que eu vivenciei que a gente falava muito pouco quando era estudante e ouvia muito mais. E de repente você se reconhece usando uma língua que não é a sua, que você não domina, mas que você quer falar para o outro o que está pensando antes de fato saber se o outro está entendendo o que você quer dizer. Então a princípio, eu falava muito e não deixava eles me perguntarem muita coisa. Quando eles me perguntavam, a nossa dinâmica, a nossa fluência na língua de sinais era muito, muito diferente então eu olhava... e respondia outra coisa porque de fato eu não entendia muito bem o que de fato tinha sido perguntado, quando eu cheguei aqui, cheguei com o nível básico, aí entrei no nível intermediário em aproximadamente seis meses, e depois do nível intermediário eu senti que tinha melhorado bastante porque também tinha sentido que realmente precisava disso, precisava assisti-los mais, precisava ver eles se expressando mais para entender o que eles estava expressando para eu me desenvolver na língua e isso de certa forma acabou se tornando parte da minha estratégia de ensino, mas antes de pensar tudo isso, durante a pós-graduação, com a questão da língua de sinais que eu ainda estou aprendendo muito, inclusive com os instrutores Surdos que vieram da escola, a gente teve instrutores muito bons, inclusive tivemos instrutores ouvintes que também eram muito bons, esse mesmo Eduardo é muito bom, Eduardo Rocha, Mariana muito boa, Jaqueline muito boa também, nosso avanço nesse espaço foi muito grande inclusive para pensar nessas estratégias, para a gente conseguir se aproximar enquanto diferença de língua né, enquanto construção de pensamento que a minha L1 é a língua portuguesa embora quando eu venho para cá hoje eu tenha uma certa dúvida de quanto essa língua se misturou com a outra né, quanto que a $\mathrm{L} 1$ vai continuar sendo a língua portuguesa, mas quando venho para cá parece uma outra situação, outro mundo de fato e na faculdade, antes de conhecer essa estrutura da língua ou a própria língua mesmo, da forma como eu conheço hoje, da forma como eu conheci ontem, sempre falaram da questão da visualidade, é marcante olha, você precisa explorar a visualidade, 
você precisa explorar o que eles vão ver, então as aulas, de uma forma geral eu sempre usei muito desenho, desenho que trazia na hora, desenho que eu fazia, foto, construções a partir de esquemas foram surgindo mais recentemente, tudo para que pudesse favorecer melhor um pouco mais do que estava sendo construído, e até isso de certa forma trouxe alguns problemas, que muitas vezes a gente deixou de trabalhar a língua, ou eu mesmo de repente passei a me ver explorando menos a língua de sinais, os classificadores porque eu me apoiava na imagem. Então ao invés de tentar mostrar a língua de sinais, utilizar um desenho assim, que de certa forma... um desenho... construir um modelo a partir da língua que eu estava usando, eu tentava mostrar uma outra linguagem, para que ela representasse o que eu faço através da língua. Na língua português isso é muito recorrente, eu me lembro muito de um exemplo que eu vivenciei no meu estágio, falando a respeito de fagocitose, aí eu estava cobrindo uma outra professora e ela me falou "hoje você vai dar aula" eu perguntei "o que eu faço?" Ela falou você vai lá e lê o livro e eles vão copiar o que você está lendo. Aí eu ditava o que estava no livro, aí eu falando sobre fagocitose "fagocitose os pseudópodes não sei o quê.... não sei o quê... das células eles englobam partículas" e todo mundo copiando mais... apáticos. Aí eu parei e perguntei vocês estão me entendendo? "Não, não estamos entendendo, então pera aí, olha só, vamos desenhar. E aí ei peguei e desenhei, e essa é uma experiência que para mim é marcante, com os ouvintes, essa experiência é marcante porque a explicação em língua portuguesa não estava sendo o suficiente para comunicar o que estávamos falando, então eu usei como recurso a imagem, mas a explicação em língua portuguesa já tinha sido feita, já tinha feito essa construção, aí completei com a imagem, muitas vezes na língua de sinais, eu pegava e fazia o que, não explorava a língua de sinais, utilizava o recurso para dar a explicação, e isso começou a acontecer o que, nós introduzimos os textos porque eu falava assim "agora a gente assiste o vídeo e a partir desse vídeo a gente vai fazer o que? Vamos produzir o texto escrito, porque o vídeo foram vocês que fizeram a partir da língua que vocês usavam, a comunicação de vocês então a gente parte da L1 para a L2" e aí eu via que na construção dos vídeos aparecia por exemplo, o estudante utilizava como referência a imagem e o que estava escrevendo ficava perdido. E em uma das construções o que que foi que aconteceu, um dos estudantes foi lá e fez o que, estava começando a escrever e ele desenhou do lado, porque ele sentiu que precisava casar uma coisa com a outra. Aí nessa história o que eu falei, a partir de agora nossa prática muda, vocês podem utilizar o desenho como recurso para lembrar, mas a explicação tem que ser feita em língua de sinais, então vocês tem que construir essa explicação também em língua de sinais. Então foi uma mudança bastante significativa e que tem tudo a ver com a estratégia de ensino que eu tenho proposto até hoje.

Apêndice 03 ao 06: (Em mídia digital) Entrevista em vídeo com o Professor de Ciências da EMEBS em que a pesquisa foi realizada. 
Apêndice 07: (Em mídia digital) vídeo de Rafael Cavichiolli fazendo uma demonstração de cadeia alimentar sem utilizar Classificadores e utilizando Classificadores na Libras. 